\title{
Solids Handling Optimization at a Small Domestic Wastewater Treatment Plant
}

\author{
Submitted by \\ A.J. MacDonald \\ B.A., B.Sc., Queen's University, Canada \\ A thesis submitted to the Faculty of Graduate Studies and Research \\ in partial fulfillment of the requirements for the degree of \\ Master of Applied Science
}

Ottawa-Carleton Institute of Environmental Engineering

Carleton University

Ottawa, Ontario, Canada

(C) A.J. MacDonald

August, 2007

The Master of Applied Science in Environmental Engineering Program is a joint program with the University of Ottawa, administered by the Ottawa-Carleton Institute for Environmental Engineering 


$\begin{array}{ll}\begin{array}{l}\text { Library and } \\ \text { Archives Canada }\end{array} & \begin{array}{l}\text { Bibliothèque et } \\ \text { Archives Canada }\end{array} \\ \begin{array}{l}\text { Published Heritage } \\ \text { Branch }\end{array} & \begin{array}{l}\text { Direction du } \\ \text { Patrimoine de l'édition }\end{array} \\ \begin{array}{l}\text { 395 Wellington Street } \\ \text { Ottawa ON K1A ON4 }\end{array} & \begin{array}{l}\text { 395, rue Wellington } \\ \text { Ottawa ON K1A ON4 } \\ \text { Canada }\end{array}\end{array}$

Your file Votre référence ISBN: 978-0-494-33661-8 Our file Notre référence ISBN: 978-0-494-33661-8

NOTICE:

The author has granted a nonexclusive license allowing Library and Archives Canada to reproduce, publish, archive, preserve, conserve, communicate to the public by telecommunication or on the Internet, loan, distribute and sell theses worldwide, for commercial or noncommercial purposes, in microform, paper, electronic and/or any other formats.

The author retains copyright ownership and moral rights in this thesis. Neither the thesis nor substantial extracts from it may be printed or otherwise reproduced without the author's permission.
AVIS:

L'auteur a accordé une licence non exclusive permettant à la Bibliothèque et Archives Canada de reproduire, publier, archiver, sauvegarder, conserver, transmettre au public par télécommunication ou par l'Internet, prêter, distribuer et vendre des thèses partout dans le monde, à des fins commerciales ou autres, sur support microforme, papier, électronique et/ou autres formats.

L'auteur conserve la propriété du droit d'auteur et des droits moraux qui protège cette thèse. $\mathrm{Ni}$ la thèse ni des extraits substantiels de celle-ci ne doivent être imprimés ou autrement reproduits sans son autorisation.
In compliance with the Canadian

Privacy Act some supporting forms may have been removed from this thesis.

While these forms may be included in the document page count, their removal does not represent any loss of content from the thesis.
Conformément à la loi canadienne sur la protection de la vie privée, quelques formulaires secondaires ont été enlevés de cette thèse.

Bien que ces formulaires aient inclus dans la pagination, il n'y aura aucun contenu manquant.

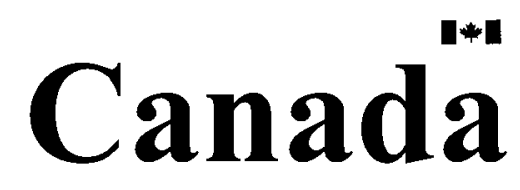




\section{Abstract}

Solids handling refers to the removal and treatment of solid matter from raw wastewater. In an activated sludge WWTP, this solid matter is typically called sludge, and its treatment and disposal may represent a significant portion of wastewater treatment expenditures. This study is focused on optimizing the solids handling at a domestic WWTP in Crystal Beach, Ontario, Canada, by two main methods. Firstly, testing was designed to test various types of polymers designed to thicken sludge after it is removed from wastewater. Secondly, an investigation was devoted to characterizing a persistent foaming problem that was known to cause problems in the clarification process, which uses gravity settling basins to separate sludge solids from wastewater. Testing took place at Crystal Beach WWTP, in Crystal Beach, Ontario, from May to December, 2006. The results of this study may be used to develop similar solids handling optimization plans at domestic wastewater treatment facilities. 


\section{Acknowledgements}

I gratefully acknowledge the help and guidance I received from my thesis supervisor Dr. Onita Basu, professor in the Civil and Environmental Engineering Department at Carleton University. She provided valuable help, advice, and information throughout my thesis work, and was responsible for initiating my research term at the Region of Niagara.

I would like to also acknowledge the role that The Region of Niagara Public Works Department, Water and Wastewater Division played in making this project possible. I received guidance and assistance from countless people who took an interest in this project. I would like to specifically acknowledge the following people for their contributions: Deanna Barrow, Chris Howard, George Bis, Mark Solomon, Ray Landry, Cameron Wilson, Kevin Booth, Dave Rodgers, Kathleen Johnstone and Norma Linkiewicz.

I would also like to thank Mark Simpson from SNF Canada, Dan Veneruzzo from CIBA Specialty Chemicals, Jack Schill from Jes-chem Canada, Fintan O'Carroll from Epsilon Chemicals, and $\mathrm{Al}$ Walz from NasChem for providing chemical samples and advice throughout this project.

Funding for this project was provided by:

Carleton University Department of Civil and Environmental Engineering The Regional Municipality of Niagara 
Table of Contents:

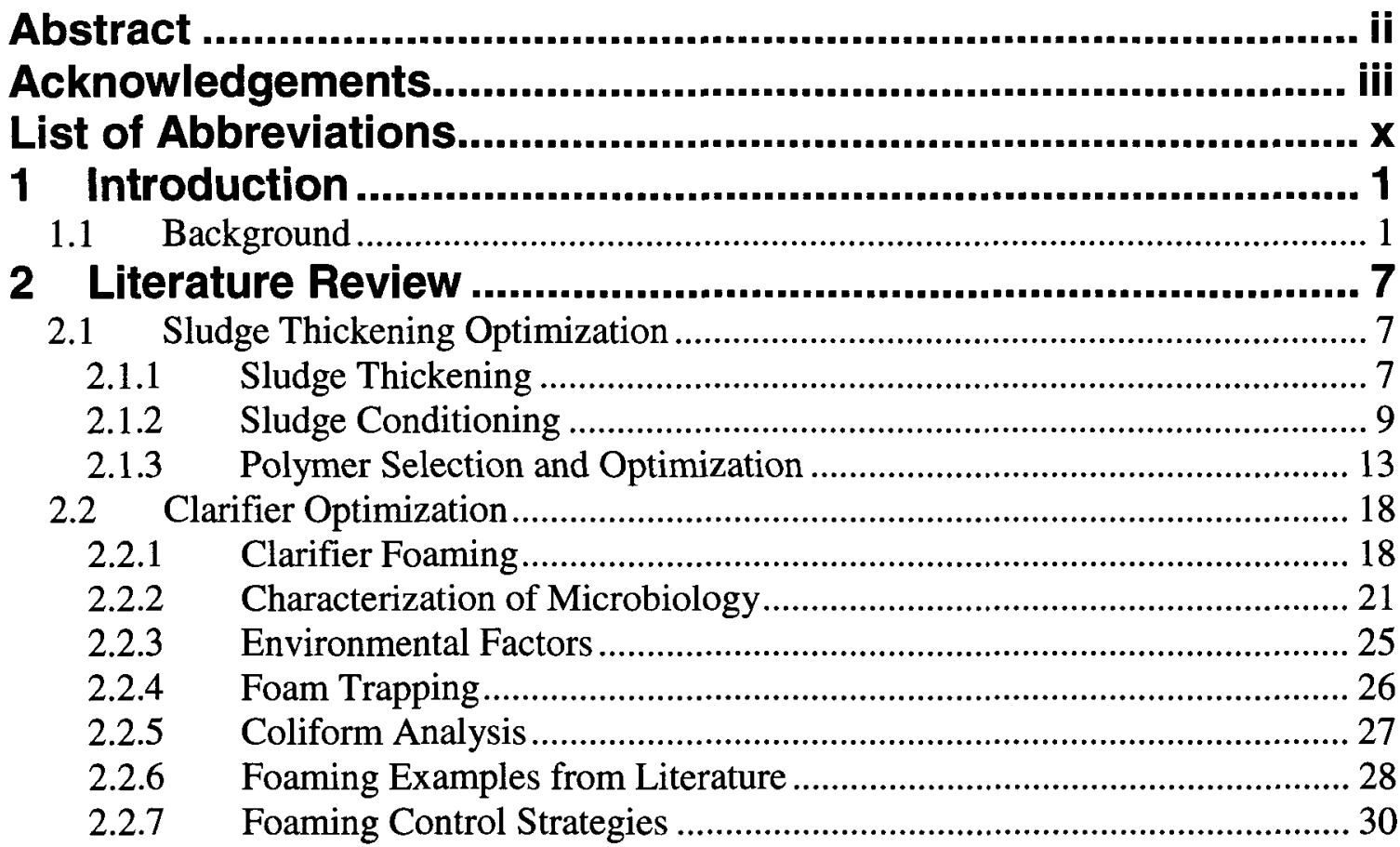

3 Methods and Materials............................................................ 35

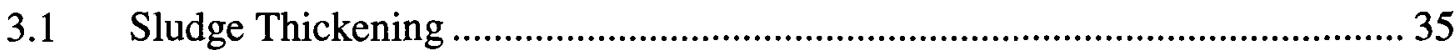

3.1.1 Polymer Preparation for Bench-Scale Testing.......................................... 35

3.1.2 Phase 1 Polymer Testing - Oxidation-Reduction Potential ........................ 36

3.1.3 Phase 2 Polymer Testing............................................................................. 37

3.1.4 Phase 3 Polymer Testing........................................................................ 44

3.1.5 Polymer Full-Scale Testing.................................................................. 45

3.1.6 Description of Thickening Process at Crystal Beach WWTP .................. 45

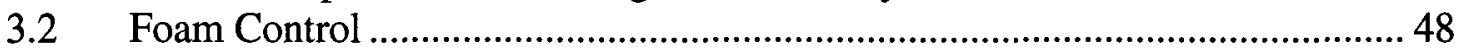

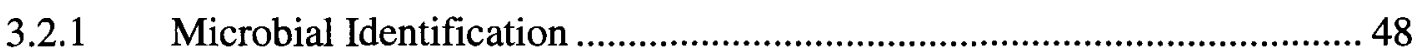

3.2.2 Microbial Enumeration ........................................................................... 49

3.2.3 Process Adjustment............................................................................. 49

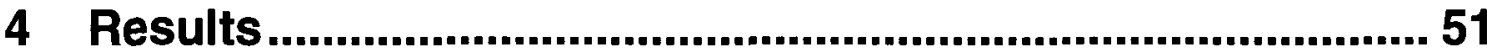

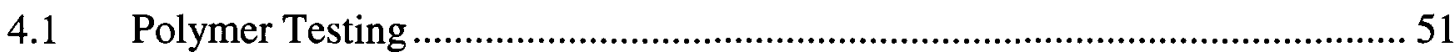

4.1.1 Pre Screening (Phase 1) ....................................................................... 51

4.1.2 Polymer Testing - Screen Test (Phase 2) ................................................... 53

4.1.3 Bench Scale Testing - Nutrient Values Adjusted........................................ 67

4.1.4 Summary of Bench-Scale Polymer Screening ...........................................69

4.1.5 Polymer Testing - Screen Test (Phase 3) ................................................. 71

4.1.6 Polymer Testing - Full Scale Trials (Phase 4).......................................... 75

4.1.7 Data From Full-Scale Sampling............................................................... 76

4.1.8 Examination of Trial Polymers at Lower Doses........................................ 84

4.1.9 Summary of Polymer Optimization ......................................................... 86

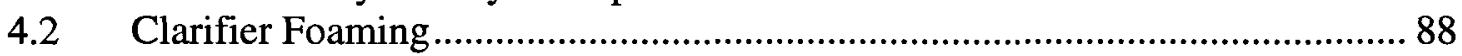

4.2.1 Microscope Analysis................................................................................ 88

4.2.2 E. Coli Enumeration Analysis.................................................................. 95 


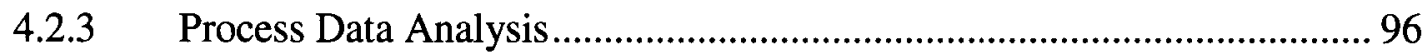

4.2.4 Control of Clarifier Foaming ............................................................... 101

4.2.5 Summary of Clarifier Foaming Research ........................................... 102

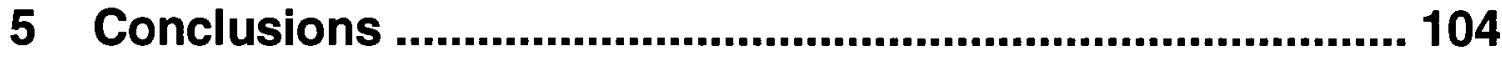

6 References........................................................................... 107

Appendix 1 - Index of Filamentous Organisms....................... 112

Appendix 2 - Calculations......................................................... 115

Appendix 3 - Foaming Spray System....................................... 119

Appendix 4 - Polymer Characteristics ...................................... 121

Appendix 5 - T test for Paired Datasets .................................... 123

Appendix 6 - Polymer Selection Using Standard Scores ........ 128

Appendix 7 - Comparison of Bench Scale and Full Scale

Polymer Testing ........................................................................... 131

Appendix 8 - Tabulated Data .................................................. 138

A8.1 Bench Scale Polymer Testing ………………………........................................ 138

A8.2 Full Scale Polymer Testing ............................................................................... 147

A8.3 E. coli Enumeration Data .............................................................................. 155

A7.4 Process Data from Crystal Beach WWTP ……………….............................. 155 


\section{List of Tables:}

Table 2.1 - Summary of Causes of Foaming Problems in Domestic WWTP................. 27

Table 3.1 - Summary of Sludge Characteristics at Crystal Beach WWTP:..................... 38

Table 3.2 - Parameters for Polymer Screening Tests:................................................. 39

Table 3.3 - Polymer Concentrations for Phase 3 and Phase 4 Testing ............................ 44

Table 4.1 - Summary of Data from Bench-Scale Polymer Testing - Solid Phase........... 70

Table 4.2 - Summary of Data from Bench-Scale Polymer Testing - Liquid Phase ........ 71

Table 4.3 - Summary of Full-Scale Data - Thickened Sludge \pm 1 Standard Deviation .. 87

Table 4.4 - Summary of Full-Scale Data - Filtrate \pm 1 Standard Deviation.................... 87

Table 4.5 - Summary of Findings of Microscope Analysis ......................................... 89

Table 4.6 - Summary of Process Parameter Records at Crystal Beach WWTP ............ 101

Table A1.1 - Filamentous Organisms that may Cause Sludge Bulking and/or Foaming

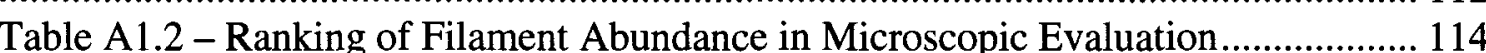

Table A2.1 - List of Derived Parameters .................................................................. 115

Table A4.1 - Polymer Characteristics .................................................................... 121

Table A5.1 - Summary of Paired T Test Results .......................................................... 125

Table A6.1 - Hypothetical Weighting Scheme for Polymer Selection .......................... 129

Table A6.2 - Summary of Combined Z-scores from Bench Scale Polymer Testing ..... 130

Table A8.1 - Polymer Solution Oxidation-Reduction Potential Data ............................ 138

Table A8.2 - Bench Scale Thickened Sludge Data .................................................... 138

Table A8.3 - Bench Scale Filtrate Data....................................................................... 139

Table A8.4 - Bench Scale Polymer Dosage Testing - Sludge Total Solids................... 140

Table A8.5 - Bench Scale Polymer Dosage Testing - Sludge TKN Concentration ...... 141

Table A8.6 - Bench Scale Polymer Dosage Testing - Sludge Total Phosphorous

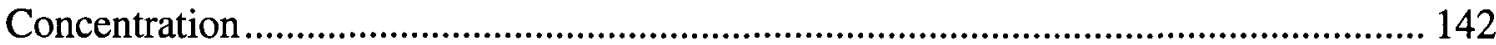

Table A8.7 - Bench Scale Polymer Dosage Testing - Filtrate Total Solids .................. 143

Table A8.8 - Bench Scale Polymer Dosage Testing - Filtrate Turbidity ....................... 144

Table A8.9 - Bench Scale Polymer Dosage Testing - Filtrate Ammonia Concentration

Table A8.10 - Bench Scale Polymer Dosage Testing - Filtrate Total Phosphorous

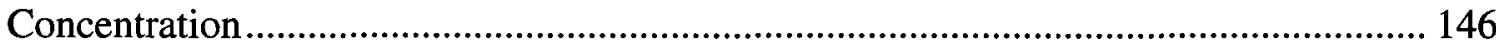

Table A8.11 - Bench Scale Polymer Dosage Testing - Filtrate Total BOD Concentration

Table A8.12 - Full Scale Thickened Sludge Data - Total Solids ..................................... 147

Table A8.13 - Full Scale Thickened Sludge Data - TKN Concentration ...................... 148

Table A8.14 - Full Scale Thickened Sludge Data - Total Phosphorous Concentration 149

Table A8.15 - Full Scale Filtrate Data - Percent Total Solids....................................... 150

Table A8.16 - Full Scale Filtrate Data - Suspended Solids Concentration ................... 151

Table A8.17 - Full Scale Filtrate Data - Turbidity ........................................................ 152

Table A8.18 - Full Scale Filtrate Data - Total Phosphorus ......................................... 153

Table A8.19 - Full Scale Filtrate Data - Ammonia ................................................... 154

Table A8.20 - E. coli Concentration Measured at Crystal Beach WWTP ..................... 155

Table A8.21 - Solid Retention Time Observed at Crystal Beach WWTP 2006 ............ 155 
Table A7.22 - Dissolved Oxygen Concentration Observed at Crystal Beach WWTP December 2006. 


\section{List of Figures:}

Figure 1.1 - Crystal Beach WWTP Activated Sludge System Schematic ....................... 5

Figure 3.2 - ORP Testing of Polymer Solution........................................................ 36

Figure 3.3 - Polymer Thickening Apparatus............................................................. 39

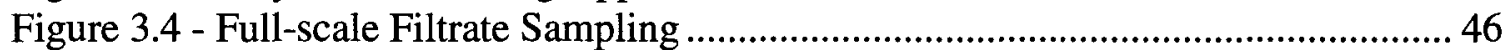

Figure 4.1 - Polymer Solution Oxidation-Reduction Potential \pm 1 Standard Deviation .. 53

Figure 4.2 - Thickened Sludge Percent Total Solids .................................................... 54

Figure 4.3 - Thickened Sludge Percent Volatile Solids ................................................. 56

Figure 4.4 - Total Phosphorous Content of Thickened Sludge....................................... 58

Figure 4.5 -Total Kjeldahl Nitrogen Content of Thickened Sludge .............................. 59

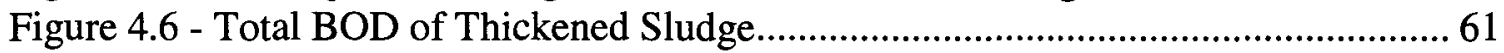

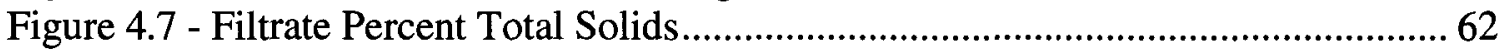

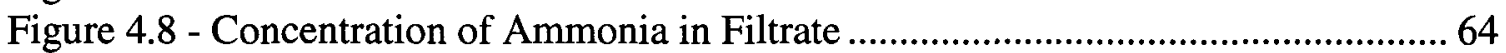

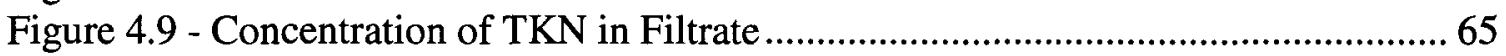

Figure 4.10 - Total Phosphorous Concentration of Filtrate ........................................... 66

Figure 4.11 - Total Phosphorous Concentration of Thickened Sludge Normalized Using

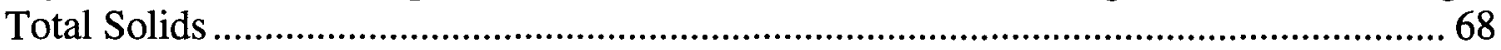

Figure 4.12 - TKN Concentration of Thickened Sludge Normalized Using Total Solids 68

Figure 4.13 - Thickened Sludge Percent Solids \pm 1 Standard Deviation Dosage Curve.. 72

Figure 4.14 - Percent Solids \pm 1 Standard Deviation and Total BOD of Filtrate ............. 73

Figure 4.15 - Filtrate Turbidity \pm 1 Standard Deviation Dosage Curve ......................... 74

Figure 4.16 - Full-scale Percent Total Solids of Thickened Sludge \pm 1 Standard Deviation

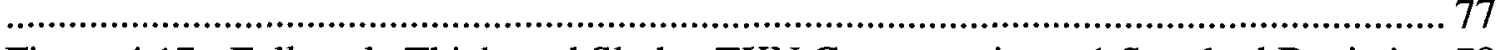

Figure 4.17 - Full-scale Thickened Sludge TKN Concentration \pm 1 Standard Deviation 78

Figure 4.18 - Full-scale Thickened Sludge Total Phosphorous Concentration \pm 1 Standard

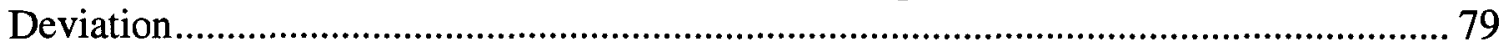

Figure 4.19 - Full-scale Suspended Solids Concentration in Filtrate \pm 1 Standard

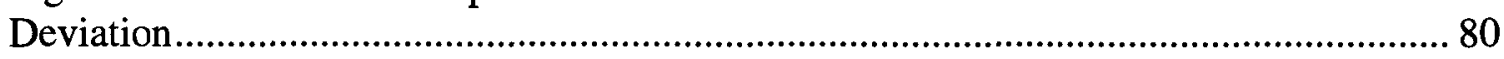

Figure 4.20 - Full-scale Filtrate Turbidity \pm 1 Standard Deviation ................................ 81

Figure 4.21 - Full-scale Total Phosphorous Concentration in Filtrate \pm 1 Standard

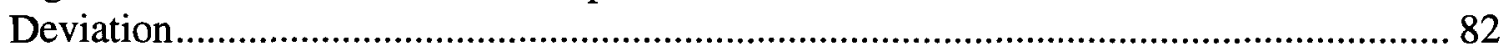

Figure 4.22 - Full-scale Ammonia Concentration in Filtrate \pm 1 Standard Deviation ..... 83

Figure 4.27 - Dilute Clarifier Foam - 100 Times Magnification ............................... 90

Figure 4.28 - Dilute Clarifier Foam - 100 Times Magnification, Gram Stained ............. 91

Figure 4.29- Clarifier Foam - 100 Times Magnification, Gram Stained ....................... 92

Figure 4.30 - Clarifier Foam at 100 times magnification, Phase Contrast ...................... 93

Figure 4.31 - Clarifier Foam - 1000 Times Magnification, Gram Stained ...................... 94

Figure 4.32 - E. coli Concentration at Three Different Sample Locations $(n=3)$............ 96

Figure 4.33 - Solid Retention Time Observed at Crystal Beach WWTP 2006 ............... 98

Figure 4.34 - F/M Ratio Observed at Crystal Beach WWTP 2006 ................................ 99

Figure 4.35 - Dissolved Oxygen Concentration Observed at Crystal Beach WWTP

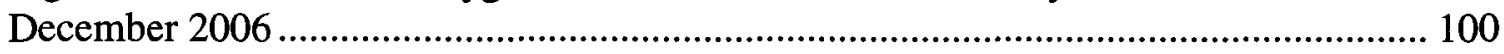

Figure A3.1 - Foam Trapping at Clarifier Inlet....................................................... 119

Figure A3.2 Spray System in Use at Crystal Beach WWTP ...................................... 120

Figure A7.1- Thickened Sludge Percent Total Solids ............................................... 131 
Figure A7.2 - Total Phosphorous Content of Thickened Sludge.

Figure A7.3 - TKN Content of Thickened Sludge ................................................ 132

Figure A7.4 - Filtrate Percent Total Solids ............................................................ 134

Figure A7.5 - Filtrate Total Phosphorous Concentration ........................................... 134

Figure A7.6 - Filtrate Ammonia Concentration ...................................................... 135 


\section{List of Abbreviations}

\begin{tabular}{|l|l|l|}
\hline Term & Definition & Units \\
\hline BOD & Biochemical Oxygen Demand & $\mathrm{mg} / \mathrm{L} ; \mathrm{mg} / \mathrm{kg}$ \\
\hline tBOD & Total Biochemical Oxygen Demand & $\mathrm{mg} / \mathrm{L} ; \mathrm{mg} / \mathrm{kg}$ \\
\hline tBOD 5 & Total Five-Day Biochemical Oxygen Demand & $\mathrm{mg} / \mathrm{L} ; \mathrm{mg} / \mathrm{kg}$ \\
\hline CBOD & Carbonaceous Biochemical Oxygen Demand & $\mathrm{mg} / \mathrm{L} ; \mathrm{mg} / \mathrm{kg}$ \\
\hline COD & Chemical Oxygen Demand & $\mathrm{mg} / \mathrm{L} ; \mathrm{mg} / \mathrm{kg}$ \\
\hline DAF & Dissolved Air Floatation Thickener & $\mathrm{N} / \mathrm{A}$ \\
\hline DO & Dissolved Oxygen Concentration & $\mathrm{mg} / \mathrm{L}$ \\
\hline F/M & Food to Microorganism Ratio & $\mathrm{mg} \mathrm{CBOD} / \mathrm{mg}$ \\
& & $\mathrm{MLVSS}$ \\
\hline GBT & Gravity Belt Thickener & $\mathrm{N} / \mathrm{A}$ \\
\hline MLVSS & Mixed Liquor Volatile Suspended Solids & $\mathrm{mg} / \mathrm{L}$ \\
\hline ORP & Oxidation-Reduction Potential & $\mathrm{mV}$ \\
\hline P & Phosphorus & $\mathrm{mg} / \mathrm{L} ; \mathrm{mg} / \mathrm{kg}$ \\
\hline RAS & Return Activated Sludge & $\mathrm{N} / \mathrm{A}$ \\
\hline RDT & Rotary Drum Thickener & $\mathrm{N} / \mathrm{A}$ \\
\hline SRT & Solid Retention Time & $\mathrm{Days}$ \\
\hline SS & Suspended Solids & $\mathrm{mg} / \mathrm{L}$ \\
\hline TKN & Total Kjeldahl Nitrogen & $\mathrm{mg} / \mathrm{L} ; \mathrm{mg} / \mathrm{kg}$ \\
\hline TSS & Total Suspended Solids & $\mathrm{mg} / \mathrm{L}$ \\
\hline VSS & Volatile Suspended Solids & $\mathrm{mg} / \mathrm{L}$ \\
\hline WAS & Waste Activated Sludge & $\mathrm{N} / \mathrm{A}$ \\
\hline WWTP & Wastewater Treatment Plant & $\mathrm{N} / \mathrm{A}$ \\
\hline
\end{tabular}




\section{Introduction}

\subsection{Background}

Wastewater treatment is the process used to remove contaminants from wastewater so that it may be reintroduced to the natural environment, protecting natural aquatic ecosystems as well as human health. A considerable amount of technology, money, time and effort are invested to ensure that treated wastewater is of sufficient quality so that natural watercourses can maintain healthy and sustainable ecosystems. However, the product of the wastewater treatment process is more than just treated water. There are also vast amounts of solids that are removed from wastewater flows. These solids, known collectively as sludge, may have very different compositions, depending on the type and level of treatment they have undergone, and also on the composition of the wastewater itself. Handling and disposal of sludge solids represents a great public expense (Krishnamurthy and Viraraghavan, 2005; Deneux-Mustin et al., 2001; US EPA, 1987), and so research efforts dedicated to improving solids handling can represent not only environmental utility, but economic benefits as well. This study is dedicated to improving solids handling at a small domestic wastewater treatment facility in Crystal Beach, Ontario.

In general, treatment processes can be divided into primary, secondary, and tertiary processes. In primary treatment, grit, fats, oils and greases are separated from the wastewater. Most primary treatment configurations consist of screening to remove large particles and grit, and primary clarification, which allows some particles to settle to the bottom of primary clarifiers, while floatable oil and grease are skimmed from the surface. 
Primary treatment produces a liquid stream, called primary effluent, and a solid product called primary sludge. In secondary treatment, primary effluent, or screened raw sewage, (where primary clarification is not utilized), is introduced to some form of biological treatment. In biological treatment, aquatic microorganisms are used to stabilize the waste, and lower the organic content and oxygen demand. There are various methods that are used to provide secondary treatment. Some systems use attached growth technology, in which bacteria grow on a solid media which passes through wastewater, (e.g. rotating biological contactors), or has wastewater pass through it, (e.g. trickling filters). A common system called an activated sludge process uses a large tank in which sewage is combined with an aquatic mixture containing a variety of microorganisms through which air is continuously passed. In some systems, where additional nutrient removal is required, processes such as denitrification, which converts ammonia to nitrates, are used (Metcalf and Eddy, 2003). Activated sludge processes, (after primary treatment), typically remove about 85 percent of the total suspended solids, (TSS) and biochemical oxygen demand, (BOD) in wastewater (Droste, 1997). The heart of the activated sludge process is the cultivation and maintenance of microbial populations that naturally process and stabilize wastewater (Metcalf and Eddy, 2003; Droste, 1997). In practice, primary effluent, (or raw sewage where primary clarification is not utilized), is combined with a suspension of microorganisms, (i.e. activated sludge; also called mixed liquor), which is aerated, and the mixture flows into clarification tanks to settle. The solids then settle to the bottom of the clarifiers, and are collected by mechanical scrapers. This separation process relies mainly on gravity, since the sludge solids are denser than water, sludge may separate from the bulk water phase, causing separation. A portion of 
the sludge, called return activated sludge (RAS), is reintroduced to the aeration system to maintain the population of microorganisms. The remainder of the sludge, called waste activated sludge (WAS), is often sent to another type of biological treatment called a digester for stabilization or may simply be collected, thickened, and disposed of in a landfill. The digestion process may use bacteria in either an aerobic or an anaerobic environment. At Crystal Beach WWTP, as in many domestic plants, an anaerobic environment is maintained for digestion. The digester is a large cylindrical tank with sloping floors and a floating roof that can accommodate fluctuations in pressure within the tank due to gas production. Before the digestion process, the WAS is first thickened from about $1 \%$ to about $4 \%$ solids, then pumped to the anaerobic digester. The digestion process involves a series of anaerobic bacterial reactions that breakdown complex molecules in the WAS, making the digested sludge relatively inert, reducing odour generation, and destroying pathogenic organisms found within undigested sludge, as well as making the sludge less likely to be a food source for disease carrying animals, (such as insects), after its final disposal (Metcalf and Eddy, 2003; Droste, 1997). Digestion also reduces the total volume of sludge, which makes hauling and disposal of digested sludge easier and more economical. Digested sludge also undergoes stabilization, which refers to the processing of sludge until decomposition is slowed and pathogens are largely destroyed or inactivated. This helps to make digested sludge suitable as a soil conditioner. The liquid effluent from secondary treatment generally undergoes final disinfection where pathogenic bacteria such as $E$. coli that may cause public health problems are decreased in number. In Ontario, standards for WWTP effluents are specific to the plant. In consultation with district and regional offices of the Ministry of 
the Environment (M.O.E.), the proponent of a WWTP is expected to conduct an assimilative capacity study of the receiving waters and to propose site specific effluent limits which are reviewed and approved. The plant is then designed to meet the criteria (Ontario Ministry of the Environment, 2007). For example, the certificate of approval at Crystal Beach WWTP allows an upper limit of 200 colony forming units of $E$. coli bacteria per 100 milliliters, $(200 \mathrm{cfu} / 100 \mathrm{~mL})$, based on a monthly geometric mean.

The WWTP at Crystal Beach is an extended aeration facility with no primary clarification. The raw wastewater is derived from domestic sources with no heavy industrial input. Influent wastewater is screened through bar screens, and grit is removed using centrifugal grit chambers, before entering plug flow aeration basins with fine bubble diffusers. Sludge is wasted from the system manually in batch fashion, at the discretion of operators. Waste activated sludge is stored in air-mixed tanks prior to thickening on a gravity belt thickener (GBT). Thickened sludge then undergoes a mesophilic anaerobic digestion process, in a floating roof digester that is mixed with a recirculation pump. Digested sludge is hauled away for disposal at sludge lagoons nearby. The design capacity of the plant is $9.1 \mathrm{ML} / \mathrm{d}$, with a peak capacity of $27.3 \mathrm{ML} / \mathrm{d}$. The average flow through the plant in 2006 was approximately $5.5 \mathrm{ML} / \mathrm{d}$, which is about 60 percent of the design capacity. A schematic of the activated sludge system at Crystal Beach WWTP is shown in Figure 1.1. 


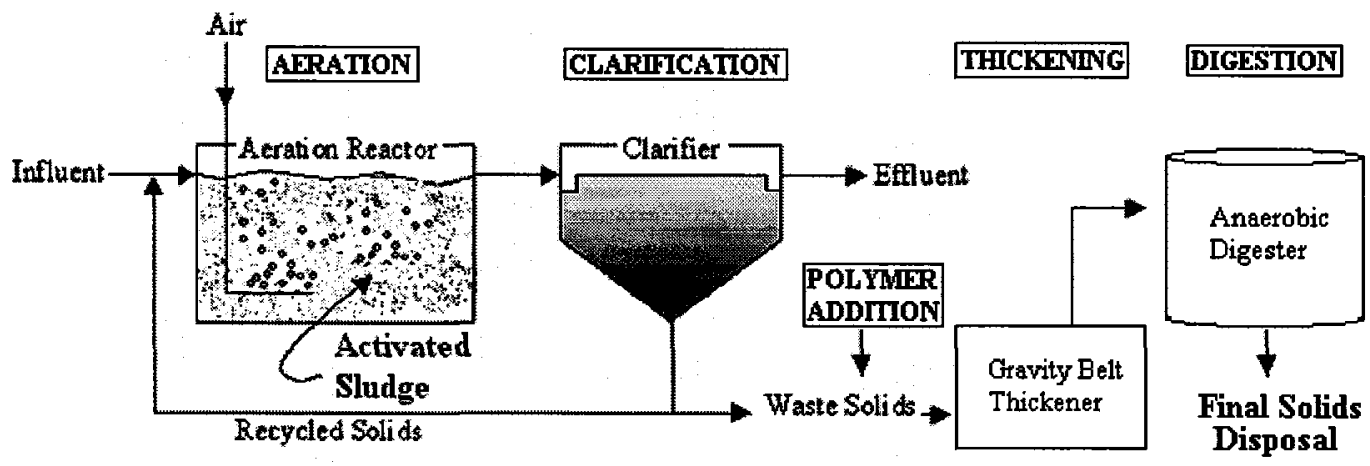

Figure 1.1 - Crystal Beach WWTP Activated Sludge System Schematic

The objective of this study is to optimize the solids handling processes at Crystal Beach WWTP, by improving the thickening of WAS before digestion, and solids separation process that occurs in the clarification process. This is broken down into two main areas: 1) Polymer selection for sludge thickening. 2) Preventing separation problems in the clarification system due to sludge foaming.

The sludge thickening study will investigate the performance of various commercially available polymers, with respect to both the solids capture and the delivery of nutrient chemicals (various compounds containing nitrogen and/or phosphorous) to solid and liquid streams. In this context, the solid stream refers to the thickened solids that are delivered to the digestion process, while the liquid stream refers to the filtrate from the thickening process, which is reincorporated with the plant influent. In other words, the examination of polymer performance will focus not only on the solids content of the thickened sludge, but also on the concentration of nutrient chemicals such as nitrogen and 
phosphorous. The selection of an optimal polymer is intended to ensure that the thickening process concentrates nutrients in the solid phase, while reducing nutrient loading in the plant from recycled liquid streams. The polymer selection process will initially be based on laboratory work, and those results will allow for the selection of candidate polymers that may be tested full-scale.

The clarification study will be focused on characterizing the causes of a continual sludge foaming problem, and identifying full-scale, process-based control methods that can ensure that conditions conducive to foaming do not occur. This is expected to improve the quality of the effluent from the activated sludge process by lowering the concentration of potentially pathogenic coliform bacteria in the effluent, and may lower the suspended solids concentration as well. This will also decrease the chlorine demand of the clarifier effluent, resulting in plant effluent of higher quality, with a lower suspended solids concentration and lower chlorine residual, representing environmental and economic benefits. The foam control research will provide plant operators with the necessary methodology for maintaining an activated sludge environment that continues to produce superior solid and liquid effluents than currently generated at Crystal Beach Wastewater Treatment Plant. 


\section{Literature Review}

\subsection{Sludge Thickening Optimization}

\subsubsection{Sludge Thickening}

Thickening is the process of removing water from WAS in order to provide sludge of lower volume and higher solids content for subsequent sludge treatment processes such as the digestion process or for final disposal. The effectiveness of a thickening operation is typically termed the solids capture, defined as the percentage of solids in the influent that is captured in the thickened sludge. For example, a solids capture of 95 percent indicates that 5 percent of the influent mass ends up as liquid, back in the treatment process train, and the remaining 95 percent of the mass is contained in the thickened sludge, delivered to subsequent solids handling process(es) (Olezskiewicz and Mavinc, 2001). There is significant variability in methods that are commonly available for sludge thickening. The simplest form of sludge thickening is gravity sedimentation. Sludge sits in a basin, (called a clarifier), typically 3 to 4 meters in depth, with a sloping floor that allows solids to be concentrated at the bottom of the tank, while the liquid supernantant can be removed from the top of the tank (Metcalf and Eddy, 2003). Most thickening processes are somewhat more complex, and use some type of machine to improve thickening over simple sedimentation. Gravity belt thickening (GBT), for example, employs a porous conveyor belt that allows conditioned sludge to be spread over the belt, concentrating solids on the top of the belt, and allowing water to pass through the pores, to be removed and delivered back to the treatment process train. The belt then travels under the unit and may be cleaned with a water spray (Kiely, 1997). Thickening by GBT 
removes the unbound water in the sludge, typically increasing the total solids concentration from about 1 percent to about 5 percent, reducing the volume of sludge by about 5 times, and concentrating the sludge before it is introduced to a subsequent digestion process (Dentel, 2001; Olezskiewicz and Mavinic, 2001; Kiely, 1997). Dissolved air flotation (DAF) is another physical separation process which saturates an unthickened sludge with air, allowing air bubbles to attach to sludge flocs, which then float the sludge to the surface of a tank. The sludge may then be removed using surface skimmers or scrapers. DAF is commonly used for activated sludge, since it is generally lighter than sludge from primary clarification (Metcalf and Eddy, 2003). The specific gravity of WAS is very close to 1.0 , which allows dissolved air to provide sufficient buoyancy for the sludge flocs to float to the surface (Vesilind et al., 1986). DAF is also commonly used in plants where it is advantageous to thicken activated sludge directly from the aeration system (Oleszkiewicz and Mavinic, 2001). Rotary drum thickeners (RDT) consist of a large cylindrical drum which uses gravity to thicken sludge as the drum is rotating in a horizontal plane. The motion of the drum causes sludge to move up the walls of the RDT, allowing free water to pass through the solids for removal (Chen $e t$ al., 2002). Another common method is the centrifuge, which is similar to the RDT, but uses a more rapid spinning motion, creating centrifugal force to shear unbound water from sludge flocs, allowing water to be removed from the unit, while sludge is thickened to a higher solids concentration (Metcalf and Eddy, 2003). The centrifuge generally consists of a bowl with a tapered end, (called the beach), which is rotated horizontally to create centripetal forces that can be many times the force of gravity. As the solids settle 
to the outside of the bowl, a spiral scroll pulls solids to the beach, while liquid centrate is removed from the opposite end (Metcalf and Eddy, 2003; Vesilind et al., 1986).

\subsubsection{Sludge Conditioning}

Thickening and dewatering of wastewater sludge is enhanced by a conditioning process. Sludge is made up of negatively charged particles in an aqueous suspension (Metcalf and Eddy, 2003; Dentel, 2001; Droste, 1997). Conditioning processes may be physical, such as using temperature to alter the structure of the sludge, or chemical, such as adding chemical additives that enhance solid-liquid separation through bond formation and charge neutralization. Overall, the chemical conditioning processes are much more popular for the treatment of wastewater sludge, since physical conditioning methods such as freezing or heating are energy intensive in most climates (Dentel, 2001). Chemical conditioning involves using additives that neutralize the charges on sludge particles, allowing the particles to agglomerate into larger particles called flocs. The negatively charged particles naturally resist clumping because they repel one another due to electrostatic forces. The conditioning process is used to stabilize the particles, neutralizing the negative charge at the particle surface, using adsorptive chemical species, or causing particles to stick together by entangling them with long polymer chains. Sometimes, both processes are used to allow flocculation to occur (Chitikela and Dentel, 1998; Droste, 1997). There are two main types of chemical sludge conditioning technology, inorganic conditioning and organic conditioning. The inorganic conditioning processes usually use some type of iron or aluminium salts, typically combined with lime. The metallic salts undergo hydrolysis and precipitation reactions, forming 
precipitates such as ferric hydroxide, which adsorbs to sludge particles, neutralizing the charges on sludge particles. Lime is often used to form calcium carbonate that reacts with the sludge, forming a conditioned sludge with less chemically bound water, and greater permeability (Dentel, 2001). Inorganic conditioning processes such as using iron salts combined with lime have been shown to alter the compressibility of the sludge, and thus are commonly used for mechanical dewatering applications, which produce sludge cake with solids content well over 10\% total solids (Novak et al., 1999). Deneux-Mustin et al., (2001), used transmission electron microscopy to examine the surface of sludge flocs during chemical conditioning. They found that a shell of crystalline precipitate was formed on the surface of flocs, maintaining floc structure and transmitting stress to inner parts of the flocs under mechanical stress. For other types of dewatering and for simple thickening applications, inorganic conditioning is seldom used, as the volume and dry weight of conditioned sludge increases, and inorganic conditioners must be used at higher doses relative to organic conditioning agents (Dentel, 2001). Dosages of chemical conditioners by weight may be as much as 30 times greater than those of organic conditioners (Krishanmurthy and Viraraghavan, 2005). In some cases, chemical conditioners may be used in conjunction with organic conditioners in order to provide both charge neutralization and interparticle bridging. The chemical conditioners provide charge neutralization, while subsequent application of polymer allows for particles to flocculate due to entanglement and bridging (Chitikela and Dentel, 1998).

Organic conditioning refers to the use of polymers to create electrolytic aqueous solutions that contain charged functional groups able to neutralize the charge on sludge particles. 
Organic polymers are also commonly known as polyelectrolytes, as they dissolve in water and dissociate into charged particles, increasing the conductivity of the solution (Dentel, 2001). Because sludge particles are mostly negatively charged, cationic polymers are frequently used to neutralize the charge and stabilize the particles (Metcalf and Eddy, 2003). Organic cationic polyelectrolytes dissociate in water into many anions, (such as $\mathrm{Cl}^{-}$), and few long chain polymers with positively charged functional groups that attract many negatively charged sludge particles, forming a floc (Dentel, 2001). In some applications, anionic or non-ionic polymers may be used. Non-ionic and/or anionic polymers may be used in conjunction with cationic polymers, to enhance floc structure by bridging and entangling effects (Ayoll et al., 2005). The increase in particle size due to conditioning allows the thickening process to produce a more porous sludge, reducing viscous drag on unbound water. The flocs are much larger and heavier than the particles before conditioning, which makes them more likely to settle, and allows unbound water in the sludge to be removed more easily (Metcalf and Eddy 2003; Chen et al., 2002; Dentel, 2001; Benitez et al., 1994).

At Crystal Beach WWTP, cationic polymers are the conditioner of choice used to neutralize the negatively charged sludge particles so that they may aggregate into flocs. Polymers tend to be popular for use in gravity drainage systems, due to their ease of use compared to alternatives such as lime and iron salts (Novak et al., 1999). Organic polymers are also popular for gravity thickening applications since they may be effective at lower doses than inorganic conditioning agents, (Krishanmurthy and Viraraghavan, 2006; Dentel, 2001; Chitikela and Dentel, 1998). Organic polymers are manufactured in 
a wide variety of molecular weight and charge, which makes them suitable for very specific applications. Organic polymers may also be advantageous from an overall environmental perspective, as they are biodegradable (Saveyn et al., 2005). In general, the most important characteristics of a polymer when considering its conditioning effectiveness with respect to given sludge are the molecular weight and charge density, (Saveyn et al., 2005; Dentel, 2001). The molecular weight of a given polymer refers to the length of the polymer chain. Higher molecular weight polymers are longer chains of monomers, and so they may be more effective at entangling sludge particles, or they may dissociate into more polymer segments in solution. The charge of a given polymer refers to the density of electrical charge that exists over the polymer molecules (Dentel, 2001). Vaxelaire and Olivier (2006), found that higher molecular weight polymers produced thickened sludge that was faster to thicken to maximum solids content, but with greater overall moisture content. Although polymers with higher molecular weight and charge density intuitively may seem to be the best choice for neutralizing charges on a suspension of sludge particles, it is important to select a polymer that works well in practice, and is economically feasible. Higher molecular weight and charge polymers may also be more expensive, so field testing of a variety of polymers is prudent. One way to characterize the ability of an aqueous polymer solution to neutralize a solution of charged particles is to measure the oxidation-reduction potential (ORP). ORP measures the ability of a solution to accept or donate electrons, and thus measures the transferability of charge provided by a given chemical species (Atkins and Jones, 2005). Since WAS is made up of a suspension of mainly negatively charged particles, we should expect WAS to have a negative ORP value, since it is an electron donor, not an acceptor. 
Cationic polymer solutions, on the other hand, should have positive ORP values, since they are electron acceptors, not donors. Polymers also come in a variety of physical configurations, including polymer solutions, polymers in emulsifications, and granular polymers available as powders or microbeads. These configurations are designed for different distribution systems that employ various methods of dissolving and/or diluting polymer prior to thickening.

\subsubsection{Polymer Selection and Optimization}

Field research of polymer testing often focuses on the ability of a given polymer to separate solids from the liquid phase within the sludge (Al-Mutairi et al., 2004; Olivier et al., 2004; Al-Muzaini and Hamoda, 1998; Severin et al., 1999; Severin and Grethlein, 1996). This information, along with the cost per unit dry solids is typically used to select a polymer for sludge thickening. The optimal dose of polymer in low pressure gravity thickening may be one that maximizes the uptake of dispersed particles into the floc structure, and so the dose is linked to the turbidity of the pre-thickened sludge (Mikkelsen and Keiding, 2001). Alternatively, the optimal polymer dose may be one that comes closest to neutralizing the charges on particles in the sludge (Dentel, 2001).

Al-Muzaini and Hamoda (1998), used a pilot-scale centrifuge unit to test the effectiveness of both centrifuge and belt filter systems to dewater WAS at a WWTP in Kuwait, and focused on the total suspended solids (TSS) and volatile suspended solids (VSS) concentrations observed in the final sludge cake. They found that polymer conditioning prior to mechanical sludge dewatering, was preferred, and achieved a total 
solids concentration of 35 percent using the belt filter press. Al Mutairi et al. (2004) compared the effectiveness of using polymer versus inorganic conditioners to condition a highly organic activated sludge produced at a slaughterhouse in Kuwait. They focused on the ability of a DAF unit to remove SS and chemical oxygen demand (COD) from the sludge. Results indicated that with respect to solids removal, the optimal dose of alum achieved 99 percent suspended solids removal, while the optimal dose of polymer achieved 96 percent removal. With respect to filterable COD, a maximum of 20 percent removal was obtained using alum, while a 43 percent removal was achieved using polymer. However, the maximum COD removal achieved using polymer was observed at much higher doses than the dose providing maximum solids removal. They found that using alum they produced a more compact sludge, but observed significant decreases in the $\mathrm{pH}$ of supernatant, from approximately 7.8 to a minimum of 4 . Ayoll et al. (2005), used a combination of both cationic and non-ionic polymers to perform bench-scale testing of sludge conditioning, focusing on the turbidity of filtrate and the shear strength of the floc structure. They found that polymer charge was important for both polymers, regardless of the order in which they were applied, suggesting that it is unlikely that the first polymer neutralizes charge, while the second polymer works primarily as a tether, bridging particles together. They found that dual polymer conditioning offered only modest advantages versus single polymer conditioning, and suggest that the additional cost associated with implementing dual polymer systems makes a full-scale application unlikely. Olivier et al. (2004) tested the performance of GBT thickening at lab scale, and predicted full-scale performance. The solids content of the thickened sludge was monitored to gauge the effectiveness of a given dose. Using an empirical model, and a 
mathematical model for gravity drainage based on Darcy's law, they scaled up bench scale results to predict full scale performance. They were able to predict full-scale performance of a belt filter based on laboratory data, and developed a model of full scale thickening performance that was within approximately 10 percent of actual results.

Overall, it appears that research in the field of sludge conditioning is more often dedicated to the conditioning and dewatering of digested sludge than to the thickening of sludge before digestion. The existing literature is commonly focused on using mainly physical parameters to characterize sludge before and after conditioning and subsequent thickening and/or dewatering processes occur. The evaluation of polymers may, however, be based not only on their performance with respect to solids capture, but also on an evaluation of how different polymers direct nutrients to solid and liquid phases during thickening. Chemicals such as ammonia nitrogen, total Kjeldahl nitrogen, (TKN), phosphorous $(\mathrm{P})$, biochemical oxygen demand (BOD), may be examined in the separated thickened solids and liquid filtrate to characterize how each polymer performs with respect to the phase selection of nutrients. These nutrients may be important to either or both of the digestion process and/or land application of biosolids after digestion. The importance of this separation process is two-fold: Firstly, the digested biosolids will be most useful and beneficial if the digested sludge is high in nutrients. They will also be more likely to meet regulations, since the land application standards in Ontario are expressed as minimum nutrient to metal ratios (Government of Ontario, 2002). The concentration of metals in sludge is correlated to the composition of the wastewater, and thus is difficult to manipulate, but if the concentration of nutrients is maximized, the 
digested sludge will be more likely to meet regulations. Secondly, understanding the differences in nutrient selection with respect to various polymers will allow for tighter control of what is recycled through the WWTP. When thickening takes place, the liquid stream, (e.g.. filtrate from a GBT), is incorporated into the inflow to the plant. This is an important mechanism, because nutrient chemicals may be removed from wastewater using expensive and/or sensitive processes. For example, phosphorous is often precipitated out of activated sludge using coagulants such as ferric chloride. Phosphorous in the form of phosphates can cause imbalances in the natural aquatic ecosystem, and so regulations limit the amount of phosphorous that may be present in WWTP effluent. To ensure regulatory compliance, coagulants are mixed with activated sludge in the aeration basins. In the case of ferric chloride, the coagulation mechanism involves a reaction between iron salts and phosphates in the activated sludge, which forms insoluble phosphorous precipitates that settle to the bottom of clarifiers (Droste, 1997). Therefore, if the phosphorous concentration of the activated sludge is increased by the recycling of phosphorous within GBT filtrate, the demand for coagulant chemicals will increase to maintain compliance. Understanding how polymers affect the nutrient concentration of solid and liquid streams may prevent using a polymer that offers solids capture advantages while simultaneously increasing chemical loading through the plant. Furthermore, in many localities, regulations require removal of various forms of nitrogen from plant effluent. In the future in Canada, implementation of the Proposed Risk Management Strategy Addressing Ammonia Dissolved in Water, Inorganic Chloramines and Chlorinated Wastewater will introduce regulations establishing or reducing limits on the maximum concentrations of various chemicals in WWTP effluent (Government of 
Canada, 2003). Thus, with respect to the nutrient loading of the plant, using a polymer that is effective at producing GBT filtrate with a relatively low nutrient concentration, (and, conversely, thickened sludge with a relatively high nutrient concentration), will be economically and environmentally advantageous.

An important consideration in any polymer selection study is the difference between bench-scale and full-scale testing. Often, a period of bench-scale or pilot-scale testing is used to test alternatives that may be identified as potential candidates for full-scale testing. This requires development of bench-scale apparatus, model(s) and testing methodology that can mimic full-scale plant behaviour. However, bench-scale conditions are only an approximation of the full-scale conditions, and thus the relative performance of alternatives observed at bench-scale may be different than that observed at full-scale. Thus, one of the secondary objectives of the polymer optimization research is to highlight important differences between the data obtained from bench-scale and full-scale testing. Some steps must be taken to ensure that bench-scale separation is a good approximation of what may be expected at full-scale. Severin and Grethlein (1996) suggest methods for mimicking full-scale belt filtration of conditioned wastewater sludge using bench-scale apparatus. They assert that bench-scale apparatus should use filter material of the same aperture size, age, and condition of the full-scale apparatus, and that loading rates should be properly scaled up using the relative surface area of surfaces in bench-scale versus full-scale testing. Severin et al. (1999) suggest that a major problem in modeling fullscale gravity drainage at full-scale is overloading the filter, and so proper loading is required. Furthermore, at full-scale, the use of plows or chicanes is useful to protect 
filters from clogging, and so simulating the action of those mechanisms at bench scale is recommended.

\subsection{Clarifier Optimization}

\subsubsection{Clarifier Foaming}

In addition to the polymer optimization study, a study designed to investigate a persistent foaming problem in the clarification basins was undertaken. Thick brown foam forms on the clarifiers and compromises the quality of the plant effluent at Crystal Beach and indeed at many WWTP locations throughout the world (Jenkins et al., 2004). This type of clarifier foaming is typically biological in origin, caused by various types of filamentous bacteria that have hydrophobic cell walls, and grow in activated sludge. The filamentous bacteria tend to grow in dense mats within the activated sludge, and can entrap gas and oils which cause the activated sludge to float on the surface of the clarifiers, instead of settling. This type of foaming is well documented in literature (Frigon et al., 2006; Jenkins et al., 2004; Richard, 2003; Parker et al., 2003; Oerther et al., 2001; Lemmer et al., 2000; Pagilla et al., 1998; Iwahori et al., 1997; Sodell and Seviour, 1996; Blackall et al., 1991; Baumann et al., 1988; Lemmer at al., 1988; Lemmer and Baumann [2], 1988; Lemmer et al., 1986). The foam may be characterized as a solids separation problem, as it can cause sludge to float on the surface of clarifiers, impacting the quality of secondary effluent (Jenkins et al., 2004; Knoop and Kunst, 1998). Because the WWTP certificates of approval require that the WWTP effluent does not exceed a given concentration of colony forming units of $E$. coli per 100 millilitres, 
excess coliform bacteria that may exist in the clarifier effluent due to the presence of activated sludge foam require excess chlorine to be neutralized. The foam also contains suspended solids that may wash over effluent weirs, increasing the suspended solids concentration of the effluent (Jenkins et al., 2004; Knoop and Kunst, 1998). Large areas of foam may also cause odour problems, and can overwhelm the scum troughs at the exit side of the clarifiers, requiring operators to descum the surface manually, using hoses. In winter months, the foam may freeze and disrupt the operation of the chain and flight sludge collectors (Jess, 2005).

Options to control clarifier foaming include installing specialized compartments in the aeration basin called selectors, or using chemicals to selectively target the foam (Jenkins et al., 2004; Parker et al., 2003), however, in the former case the selector cells may be expensive to implement and in the latter the chemicals mask the problem instead of solving the reason for the foam generation. Thus, the purpose of this part of the project is to attempt to characterize the plant characteristics that may cause foaming, and to highlight possible process-based solutions that will not require physical alteration to the structure of the plant.

The characterization of foaming problems in WWTP often involves examining the microbial population responsible for the foaming, quantifying the concentration of bacteria in the foam and identifying where the bacteria proliferate. Applying processbased control strategies that do not involve large-scale, capital-intensive alterations of the plant may then be used to rule out where the causes for foaming exist. The purpose of 
the microbial analysis is to: 1 . Identify which types of foaming bacteria are present; 2 . Identify where the microbes responsible for the foaming initiate; 3 . Determine if and where microbes may be proliferating throughout the treatment process. This is accomplished by examining samples of plant contents at various locations throughout the treatment train. These types of projects are typically undertaken at full-scale in continuously operating plants, and so any adjustment to the parameters or conditions within the WWTP must be performed slowly, in order to avoid or reduce upset to the activated sludge system.

There is a significant body of literature on the subject of foaming in activated sludge plants that includes information on the growth and characteristics of the causative bacteria (Eales et al., 2005; Jenkins et al., 2004; Lemmer et al., 2000; Iwahori et al., 1997; Kappeler and Gujer, 1994). Some research is devoted to surveys of individual plants across various regions (Blackall et al., 1991; Lemmer and Baumann, 1988), and evaluations of the effectiveness of control strategies (Jenkins et al., 2004; Parker et al., 2003). This work will provide an example of a single, small Canadian plant, and evaluate the potential effectiveness of low-cost, process-based controls, implemented full-scale to combat foaming in the activated sludge system. Furthermore, this study will underscore the importance of taking an exhaustive, scientific approach to identifying foaming problems. Because foaming problems are typically the result of various causative factors, which may be difficult to discover and to control, it is essential to isolate important preconditions for foaming wherever possible. 


\subsubsection{Characterization of Microbiology}

The microbiology of the foam is an important characterization. Foaming may be caused by a multitude of different types of organisms, which can occur in different environments (Jenkins et al., 2004; Richard, 2003; Lemmer et al., 2000). Appendix 1 provides a list of common organisms found in foaming WWTP, including characteristics and causes. Jenkins et al. (2004), implicate 26 different types of bacteria, and various types of fungi that may cause activated sludge to exhibit bulking, foaming, or both during aeration and clarification processes. In general, the goal of microbiological characterization is to understand which type(s) of microorganisms may dominate the foam layer, allowing for an evaluation of the plant conditions that allow a given population of microorganisms to survive. Using this information, it is possible to consult literature sources that focus on the ecology of various types of filamentous bacteria, to implicate conditions at the plant which may be conducive to foaming problems. Richard (2003), suggests that there are various microbial reasons for sludge separation problems. Slime bulking and foaming may occur when bacteria in sludge flocs produce excess amounts of polysaccharide. This tends to occur during periods of high organic loading, when the food to microorganism, (F/M) ratio is high. In other words, the amount of biochemical oxygen demand, (or BOD, a surrogate measure of the substrate available), coming in, divided by the mass of mixed liquor volatile suspended solids, (MLVSS, a surrogate measure of the mass of organisms in activated sludge), is higher than optimal. According to Jenkins et al (2004), slime bulking, also known as viscous bulking, can occur in plants when wastewater is characterized by abundant amounts of soluble and metabolizable organics, but chemical nutrients such as phosphorous and nitrogen are deficient. Even when nutrients are 
present in sufficient amounts, slime bulking and foaming can occur when the activated sludge organisms are operating at high metabolic rates. Zoogloea bulking and foaming can occur when Zoogloea ramigera, a common bacteria found in sludge flocs, becomes overgrown, causing sludge bulking, and hindering sludge settling (Jenkins et al., 2004; Richard, 2003). Richard (2003) suggests that Zoogloea bulking and foaming occur when the polysaccharide levels in sludge are normal, but low oxygen levels have encouraged formation of organic acids that stimulate growth of $Z$. ramigera. Fungi have also been implicated as potential agents causing foaming problems. The appearance of fungi at levels great enough to cause solids separation problems has been shown to occur mainly at low pH levels, particularly in plants that accept acidic industrial wastes (Jenkins et al., 2004; Richard, 2003). Treatment plants that exhibit nutrient deficient environments may also develop foaming problems due to filamentous bacteria. Jenkins et al. (2004) implicate nutrient deficiency as a possible cause for bulking and foaming bacteria such as Thiothrix spp, S. Natans, H. hydrossis, $N$. limicola III and Type 021N. Foaming due to nutrient deficiency is unlikely to occur in a domestic WWTP since domestic wastewater tends to be rich in nutrients. Plants that use a nitrification-denitrification process to convert ammonia nitrogen to nitrogen gas may also be susceptible to foaming, as nitrogen bubbles produced in denitrification can provide buoyancy to sludge particles (Jenkins et al., 2004).

A common and persistent type of foaming observed in domestic WWTP occurs due to a large biomass of filamentous bacteria that may cause sludge to float on clarifier surfaces instead of settling. One of the most commonly implicated types of foam-forming bacteria 
is Microthrix parvicella. These filamentous organisms have hydrophobic cell walls, and can cause stable foams on clarifier and digester surfaces, by causing bridging between sludge flocs, and entrapping gas and hydrophobic substrates (Jenkins et al., 2004; Westlund et al., 1998). This type of foaming is often observed in plants where the retention time of activated sludge within the aeration system (called solids retention time or SRT), is above optimal, the dissolved oxygen concentration (DO) concentration is below optimal, and temperatures in aeration reactors are below about 15 degrees Celsius (Jenkins et al., 2004; Richard, 2003; Lemmer et al., 2000; Knoop and Kunst, 1998). Knoop and Kunst (1998) surveyed activated sludge WWTP with various nutrient loading rates and nutrient removal processes, and found that $M$. parvicella occurred most often in nitrification-denitrification configurations which operate at high SRT, (over approximately 15 days), and seasonally in spring and fall, when activated sludge temperature drops below 12 to 15 degrees Celsius. Furthermore, they found that $M$. parvicella is more common in plants with relatively higher sludge loading rates. Eikelboom et al. (1998) found that $M$. parvicella was the most common filamentous microorganism observed in nutrient removal WWTP in a survey of four countries in Northern Europe. They looked specifically at nutrient removal WWTP because they tend to operate at higher SRT in order to remove ammonia-nitrogen through nitrificationdenitrification reactions. They suggest that low activated sludge temperature, and presettling of influent, (i.e. primary clarification), are two factors that may increase the abundance of $M$. parvicella. 
Filamentous foaming is also commonly caused by a type of filamentous bacteria known as actinomycetes or mycolata (Frigon et al., 2006; Jenkins et al., 2004; Richard, 2003; Oerther et al., 2001; Lemmer et al., 2000; Iwahori et al., 1997; Blackall et al., 1991; Baumann et al., 1988; Lemmer and Baumann, 1988; Lemmer and Baumann [2], 1988; Lemmer, 1986). These bacteria, which are of the genus Nocardia, have hydrophobic cell walls, and form the basis of a foam layer made up of stable, gas filled cells that strongly resist settling (Lemmer et al., 2000). When organic loading is low, and F/M ratio drops, Nocardia bacteria grow excessively, and are able to feed selectively on hydrophobic substrates at the gas-water interface (Richard, 2003; Lemmer et al., 2000). Soddell and Seviour (1996) examined the growth kinetics of Nocardia pinensis on various substrates. Their study indicated that this type of organism grows at a faster rate and produces a more substantial biomass on hydrophobic substrates such as polysorbate 80 , (a nonionic detergent and emulsifier derived from polyoxylated sorbitol and oleic acid), and olive oil than the more ubiquitous glucose, a simple sugar. They suggest that uptake of glucose by some Nocardia bacteria may be increased, however, when surface-active ingredients are included in the growth medium. Eales et al. (2005) also studied the effects of hydrophobic substrates on Nocardia pinensis, and found that these organisms are capable of utilizing the hydrophobic substrate oleic acid under aerobic, anaerobic, and anoxic conditions. Baumann et al. (1988) suggest that the ability to grow on refractory substrates such as complex organic acids and pesticides may give foam-causing bacteria a selective advantage over some other types of activated sludge microorganisms, but only when the generation time is long enough to allow the slow metabolization processes to occur. Many of the more desirable microorganisms in activated sludge grow more 
quickly than foam causing bacteria when substrates are abundant and easily metabolised, but the foam causing bacteria can grow slowly on less easily metabolized substrates while the other types of microorganisms starve (Baumann et al., 1988; Lemmer, 1986). Furthermore, the hydrophobic cell walls of foam-causing bacteria may provide an advantage over other microorganisms in activated sludge because hydrophobic substrates may become concentrated at the gas-liquid interface of air bubbles, forming micro-zones rich with nutrients available to the foam-forming bacteria (Lemmer and Baumann, 1988). The foam-forming bacteria can multiply and proliferate while floating on clarifiers, due to their ability to exploit the nutrient rich gas-liquid interfaces, and to their ability to store polyphosphates and poly-Beta-hydroxybutyric acid as a food source during starvation cycles (Lemmer and Baumann [2], 1988). Thus, the input of oils and grease into the WWTP may cause excessive episodes of foaming to occur, as an abundance of hydrophobic substrates may offer advantages to microorganisms that can cause foaming. High grease and oil inputs into secondary treatment processes may also occur in plants where primary clarification is not used, since oil and grease are partially removed during primary clarification (Lemmer et al., 2000).

\subsubsection{Environmental Factors}

Some environmental features of the activated sludge process can cause various types of foam-causing bacteria to occur. Scruggs and Randall (1998) developed laboratory-scale apparatus to test the effects of DO concentration and F/M ratio on various species of filamentous bacteria known to cause foaming or bulking problems. To test the effect of $\mathrm{DO}$, they maintained a constant $\mathrm{F} / \mathrm{M}$ ratio and varied $\mathrm{DO}$ in the aeration reactor. They 
found that the growth of Nocardia was enhanced by DO concentrations above $1.0 \mathrm{mg} / \mathrm{L}$. They observed a nearly linear increase in growth relative to DO as concentration increased from 1.0 to $5.0 \mathrm{mg} / \mathrm{L}$. When DO was held constant and the F/M ratio was varied, Nocardia was observed to be stimulated at F/M ratios of approximately 0.1 to 0.2 mg soluble chemical oxygen demand per mg mixed liquor suspended solids. Around this same range of F/M ratio, some other types of filamentous bacteria that have been observed to cause bulking and/or foaming to occur, such as type 0041, and type 1851 bacteria. Thus, these types of bacteria, (including Nocardia), are sometimes known as low F/M filaments.

\subsubsection{Foam Trapping}

A phenomenon known as foam trapping has also been implicated as a possible aggravation to foaming problems (Jenkins et al., 2004; Cha et al., 1992). When floating foam is trapped due to physical features of the plant, such as restrictive piping or baffles between aeration basins and clarifiers, the volume of foam is observed to increase. Cha et al. (1992) performed tests using simulated foam trapping at bench-scale. They found that foam trapping configurations increased Nocardia filament counts up to five times. Jenkins et al. (2004) observed that plants with multiple paths between aeration basins and clarifiers with varying degrees of foam trapping potential exhibit more intense foaming where foam trapping features are more effective at trapping foam. Blackall et al. (1991) performed lab experiments that mimicked foam trapping by growing floating Nocardia filaments and removing bulk liquid from below the surface. They found that subsurface 
withdrawal of cultures (as opposed to surface withdrawal), encouraged growth of

Nocardia amarae. A summary of common causes of foaming is shown in Table 2.1.

Table 2.1 - Summary of Causes of Foaming Problems in Domestic WWTP

\begin{tabular}{|l|l|l|l|}
\hline Type of Foaming & Description & Causes & Reference \\
\hline Dispersed Growth & $\begin{array}{l}\text { High growth rate of } \\
\text { floc-forming species } \\
\text { causes excessive } \\
\text { bacterial growth with } \\
\text { poor flocculation of } \\
\text { sludge, causing poor } \\
\text { settling }\end{array}$ & $\begin{array}{l}\text { Organic loading rate is } \\
\text { too high, requiring } \\
\text { reduction in food to } \\
\text { microorganism ratio }\end{array}$ & $\begin{array}{l}\text { Jenkins } \text { et al., 2004; } \\
\text { Richard, 2003 }\end{array}$ \\
\hline $\begin{array}{l}\text { Nitrification and } \\
\text { Denitrification }\end{array}$ & $\begin{array}{l}\text { Gas bubbles from } \\
\text { nitrification and } \\
\text { denitrification may } \\
\text { cause sludge blanket to } \\
\text { float to surface of } \\
\text { clarifiers }\end{array}$ & $\begin{array}{l}\text { High SRT; DO too low; } \\
\text { sludge blanket spends } \\
\text { too much time in } \\
\text { clarifiers }\end{array}$ & $\begin{array}{l}\text { Jenkins } \text { et al., 2004; } \\
\text { Richard, 2003 }\end{array}$ \\
\hline $\begin{array}{l}\text { Zoogleal } \text { Bulking and } \\
\text { Foaming }\end{array}$ & $\begin{array}{l}\text { Viscous, bulking and } \\
\text { poorly settling sludge } \\
\text { may form layer of foam } \\
\text { in aeration and/or } \\
\text { clarification system(s) }\end{array}$ & $\begin{array}{l}\text { Excessive amount of } \\
\text { exocellular polymer due } \\
\text { to high carbohydrate } \\
\text { loading; high F/M ratio }\end{array}$ & $\begin{array}{l}\text { Jenkins } \text { et al., 2004; } \\
\text { Richard, 2003 }\end{array}$ \\
\hline Type 1863 Foaming & $\begin{array}{l}\text { White, air-filled, } \\
\text { collapsible foam }\end{array}$ & $\begin{array}{l}\text { SRT too low; may be } \\
\text { due to hydraulic short- } \\
\text { circuiting }\end{array}$ & Richard, 2003 \\
\hline M. Parvicella Foaming & $\begin{array}{l}\text { Thick, brown, viscous } \\
\text { foam in clarifiers and/or } \\
\text { digesters }\end{array}$ & $\begin{array}{l}\text { High SRT, low } \\
\text { temperature, low Do } \\
\text { concentration }\end{array}$ & $\begin{array}{l}\text { Jenkins } \text { et al., 2004; } \\
\text { Richard, 2003; Knoop } \\
\text { and Kunst, 1998 }\end{array}$ \\
\hline Nocardia Foaming & $\begin{array}{l}\text { Thick, brown, viscous } \\
\text { foam in aeration and } \\
\text { clarification systems }\end{array}$ & $\begin{array}{l}\text { High SRT, high aeration } \\
\text { system temperature, } \\
\text { exacerbated by foam } \\
\text { trapping }\end{array}$ & $\begin{array}{l}\text { Jenkins } \text { et al., 2004; } \\
\text { Richard, 2003; Frigon } \text { et } \\
\text { al., 2006 }\end{array}$ \\
\hline
\end{tabular}

\subsubsection{Coliform Analysis}

Another important facet of the microbial analysis of the foam is to identify the concentration of coliform bacteria in the foam. Coliform bacteria in natural aquatic environments may cause public health problems, as some species of coliform bacteria can cause debilitating and/or fatal reactions in humans (Droste, 1997). Activated sludge contains high concentrations of coliform bacteria, and so because the foaming problem 
brings activated sludge to the surface of the clarifiers, it is possible that the foam causes a greater concentration of coliform bacteria to be present in the secondary clarifier effluent. To maintain regulatory compliance, disinfection processes are used to destroy or inactivate coliform bacteria. Thus, identifying coliform bacteria in the foam justifies the eradication of the foam from a public health perspective. To test samples of clarifier liquid and foam, the most probable number technique is recommended, as this allows for relatively large samples to be tested, relative to alternative coliform enumeration techniques such as the colony count technique (American Public Health Association, 1998).

\subsubsection{Foaming Examples from Literature}

Blackall et al. (1991) conducted a survey of 283 samples from 46 plants in Queensland, Australia. Using microscopic identification and gram-staining, they identified Nocardia amarae and Nocardia pinensis as the most common organisms found to be concentrated in the foam phase. They also found significant amounts of other Nocardioform species. Frigon et al. (2006) conducted an 8 year surveillance study of a WWTP in Illinois that was know to persistently exhibit seasonal episodes of foaming. They identified Gordonia amarae, (also known as Nocardia amarae), Skermania piniformis, (an organism related to Nocardia pinensis), and Rhodococcus rhodochrous as the dominant organisms. Collectively, these organisms are called mycolata, referring to actinomycetes containing mycolic acid. The authors suggest two main factors that may be responsible for the observed foaming problems: 1.) an activated sludge reactor temperature above 18 degrees Celsius, and 2.) bypass of primary clarifiers They surmise that bypassing of the primary 
clarifiers allows elevated levels of oil, grease, and hydrophobic substrates into the activated sludge reactor, which provide substrate for foam-causing filamentous bacteria. Using samples from the same WWTP, Oerther et al. (2001) quantified the actual concentrations of Nocardia bacteria in activated sludge using bench-scale tests and fullscale assays. They discovered that foaming incidents were concurrent with relatively large populations of filamentous bacteria. The abundance of Nocardia bacteria was observed to increase fivefold during foaming. They implicate several conditions as important precursors to foaming episodes, including high aeration reactor temperature (greater than or equal to 23 degrees Celsius), high MLSS concentration, (above 1900 $\mathrm{mg} / \mathrm{L}$ ), higher SRT, and low F/M ratio. In Japan, Iwahori et al. (1997), conducted a oneyear survey of a plant known to have continual foaming problems. The foam layer occurred in the aeration cells and secondary clarifiers, and was shown microscopically to have a dominant population of Nocardia Amarae bacteria. The authors surmised that the Nocardia bacteria are concentrated at various points in the plant. Firstly, they suggest that recycling of foam removed from the secondary clarifiers back to the primary clarifiers concentrates Nocardia bacteria in the primary clarifiers. Secondly, Nocardia bacteria are concentrated in the aeration system, as this is the only part of the plant where Nocardia bacteria actually grow. Using mass balances, the authors showed that 95 percent of the Nocardia bacteria in secondary clarifier influent were returned at some point to the aeration system, greatly increasing the retention time of scum causing bacteria versus settlable solids in the treatment system. The effect of recycle streams on plants that exhibited foaming problems was also investigated by Pagilla et al. (1998). The authors found that Nocardia bacteria may reseed populations upstream when recycle 
streams, (such as RAS recycle or DAF thickener supernatant), are reintroduced to secondary treatment. They focused especially on DAF liquid streams being recycled, and concluded that reseeding may occur due to floc breakdown, whereby Nocardia bacteria within the floc may be exposed, or due to lysed bacterial cells releasing foam-stabilizing compounds in the digester. They also concluded that the reseeding mechanism may be so effective that Nocardia in WAS can reseed populations in the aeration system, even when filament counting analysis of recycle streams does not indicate that Nocardia bacteria are present.

\subsubsection{Foaming Control Strategies}

There are various methods that may be useful for controlling the occurrence of foaming in activated sludge WWTPs. Jenkins et al. (2004) suggest that process-based control strategies may be difficult to implement and control, particularly when a large portion of the plant solids inventory is incorporated in the foam layer. They suggest that providing different types of specialized environments in specialized reactors called selectors may be used to provide an environment in which desirable activated sludge microorganisms are able to uptake substrate faster than scum forming bacteria such as Nocardia. In an experiment by Cha et al. (1992), it was shown that Nocardia filament counts were significantly lower in an aerobic selector when compared to a completely mixed aeration reactor, (which was maintained at the same temperature and DO concentration as the selector), when the retention time of the selector was 5 days. At a solids retention time of 10 days, the Nocardia filament counts were much closer in magnitude in the two environments. In an anoxic selector, (i.e. one in which oxygen is not present but nitrite or 
nitrate is), using a retention time of 12 days, Nocardia filament counts were reduced by about 75 percent after 48 days. Anaerobic selectors have been shown to be effective in some instances, but only when enhanced biological phosphorous removal is practiced (Jenkins et al., 2004; Blackall et al., 1991). Another type of selector, known as a classifying selector, has also been used to control Nocardia foaming with some success. This technology uses a physical process to selectively waste foam solids prior to secondary clarification, in order to prevent foaming in clarifiers. The classifying selector allows floating foam on the aeration tanks that is high in foam-causing bacteria to flow out of the activated sludge system for disposal (Jenkins et al., 2004; Parker et al., 2003). Parker et al. (2003) performed a survey of seven plants with foaming problems in the United States, most of which had foam trapping problems that were thought to intensify the problem. The installation of classifying selectors was observed to remove some or all of the observed foam on secondary clarifiers.

Various chemical methods of foaming suppression have been attempted at wastewater treatment plants. For example, chlorination has become a relatively common method used to neutralize foam-causing filamentous bacteria (Jess, 2005; Jenkins et al., 2004). One way of using disinfectant chemicals is to introduce them into RAS flows, in order to destroy foam-causing bacteria before they are reintroduced into the aeration system. This may be a problematic strategy, as chlorine dosing of RAS will result in the destruction of beneficial organisms as well as deleterious ones. Excessive doses can also cause floc break-up, which may hamper downstream solids separation processes (Jenkins et al., 2004). A potentially more effective method of using disinfectant chemicals to control 
foaming is to use a spray system to contact the surface of floating foam (Jess, 2005; Jenkins et al., 2004). Jess (2005) showed that a rudimentary surface spray system that used a chlorinated solution sprayed on the surface of biological foam with shower heads eradicated a clarifier foaming problem at a WWTP in Calgary. In practice, this type of system may represent a way to use foam trapping as an advantage, since foam is easily targeted in a contained environment, and altering structural components of existing plants with foam trapping problems is a difficult task. Chemical methods of foam control also include the use of anti-foaming agents or filamenticides that are designed to cause chemical reactions that eliminate biological foams. These may be proprietary chemicals that are produced for specific applications. Although research of these types of chemicals is lacking, some suggest that these can produce effluent toxicity if used improperly (Jenkins et al., 2004). Chemical methods of controlling foam-causing bacteria may also be useful if the filamentous bacteria population may be reseeded by the recycle streams. If it is discovered that the filamentous bacteria are able to survive in part due to reseeding of the population by recycling processes, selectively destroying these bacteria before they re-enter the activated sludge system may mitigate foaming problems (Jenkins et al., 2004; Pagilla et al., 1998).

The addition of cationic polymers to activated sludge in the aeration basin has been used in some plants to control Nocardia foaming. Clarifier foaming may be due to the presence of Nocardia filaments both within sludge flocs, and those floating freely in mixed liquor, and so the use of polymers to coagulate free-floating filaments is a logical control measure (Jenkins et al., 2004; Shao et al., 1997). Shao et al. (1997) performed 
experiments that suggest that free-floating Nocardia bacteria are more effective at causing foaming problems than those contained within flocs. They surmised that anionic surfactants in the influent at a WWTP in Los Angeles may be contributing to Nocardia foaming in the aeration and clarification systems, and so they experimented with addition of a cationic polyacrylamide solution. They found that polymer addition eliminated the episodic foaming problem. Jenkins et al. (2004) discuss polymer addition to prevent foaming and bulking problems, and warn that polymer addition for these purposes should be closely controlled and monitored to prevent sludge gelling, which may in fact make bulking and/or settling problems worse. A major disadvantage of polymer addition to control bulking or foaming problems is the expense associated with an increased continuous polymer demand in the plant.

According to many sources (Frigon et al., 2006; Jenkins et al., 2004; Iwahori et al., 1997; Blackall et al., 1991; Lemmer, 1986) the time that microorganisms spend in the activated sludge system, (i.e. the SRT), may be an important control on the occurrence and persistence of foaming in the secondary clarifier. This is mainly because foam-causing bacteria tend to be slowly growing relative to other microorganisms in the activated sludge, and develop significant populations only if given sufficient time to grow and multiply (Jenkins et al., 2004; Baumann et al., 1988; Lemmer, 1986). Kappeler and Gujer (1994) suggest that scum causing bacteria may be washed out of WWTPs at low solids retention times of approximately 2 days. Even when the average SRT is relatively low, erratic SRT may encourage foam-causing bacteria to proliferate in periods of relatively high SRT, and remain in the activated sludge system due to the influence of recycle 
streams and/or foam-trapping (Jenkins $e$ al., 2004). Therefore, it may be advantageous to implement automatic SRT control using computer-based process logic that maintains a pre-set SRT. Jenkins et al. (2004), suggest that it is possible to maintain a foam-free environment at higher SRT with automatic SRT control, compared to when SRT is controlled manually. Automating SRT involves returning RAS and wasting WAS from the activated sludge system at a constant rate, so that the amount of time that activated sludge solids spend in the process train is maintained at a constant value. This type of process control may also be used to regulate the F/M ratio, especially at domestic plants such as Crystal Beach WWTP, where the composition of the influent remains relatively constant, because the concentration of microorganisms in the activated sludge, (approximated by the MLVSS concentration), remains constant. This is an important consideration because the food to micro-organism (F/M) ratio, defined as the mass of incoming carbonaceous BOD per day, divided by the mass of micro-organisms housed in the aeration basins, (which is related to the SRT), may also be an important control on the prevalence of foaming (Jenkins et al., 2004; Kappeler and Brodmann, 1995; Lemmer 1986). Because the slowly growing filamentous bacteria can metabolize a larger variety of substrates relative to other microorganisms in activated sludge, foam-causing bacteria may obtain a competitive advantage at low F/M ratios (Jenkins et al., 2004; Kappeler and Brodmann, 1995; Blackall et al., 1991). Although it is difficult to alter the character of the plant influent, (i.e. the food), it is possible to adjust the amount of microorganisms in the aeration basin by controlling the ratio of the amount of sludge wasted to the amount of sludge returned (Metcalf and Eddy, 2003; Droste, 1997). 


\section{Methods and Materials}

\subsection{Sludge Thickening}

The polymer selection process employed 4 phases. From a group of 20 samples, 3 were selected for full-scale testing. The progression is outlined in Figure 3.1.

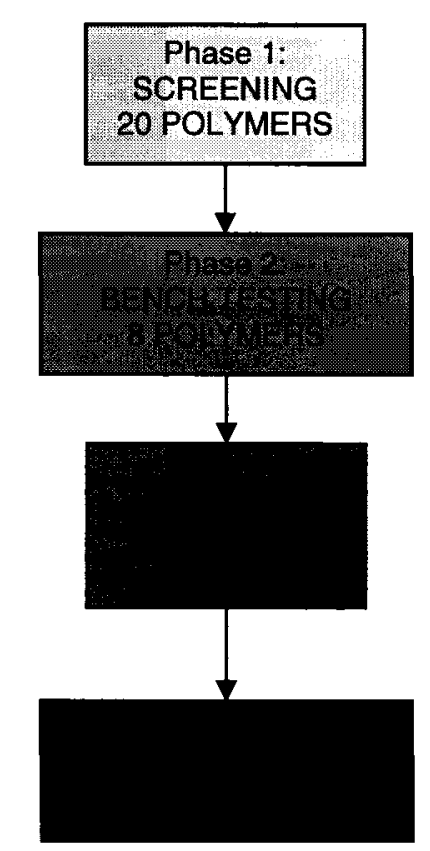

Figure 3.1 - Polymer Testing Progression

\subsubsection{Polymer Preparation for Bench-Scale Testing}

All polymers tested in this study are cationic granular polymers. For all bench-scale testing, each type of polymer is prepared in a stock solution at $0.1 \%$, using tap water at 20 degrees Celsius. Each solution is mixed on a jar test apparatus at $25 \mathrm{rpm}$ for 1 hour. Polymer solutions are prepared each day for testing. 


\subsubsection{Phase 1 Polymer Testing - Oxidation-Reduction Potential}

Polymer solutions are prepared in triplicate for phase 1 testing. To characterize the ability of the polymers to neutralize the negatively charged particles within the WAS, the polymer solutions are tested for oxidation-reduction potential (ORP) using an extech RE300 handheld probe. This device measures the ability of a solution to donate or accept electrons, and thus gives a measure of the polymers ability to neutralize charged sludge particles, and allow flocculation to occur. After the probe is inserted into the polymer solution, the reading is allowed to stabilize for at least 90 seconds, and each solution is tested twice. 1.00 M KCL standard redox solution is used as a reference standard after every measurement. The calculation of the oxidation-reduction potential (ORP) is done using methods described in Standard Methods, $20^{\text {th }}$ edition, (American Public Health Association, 1998). ORP testing is shown below in Figure 3.2. See Appendix 2 for calculations.

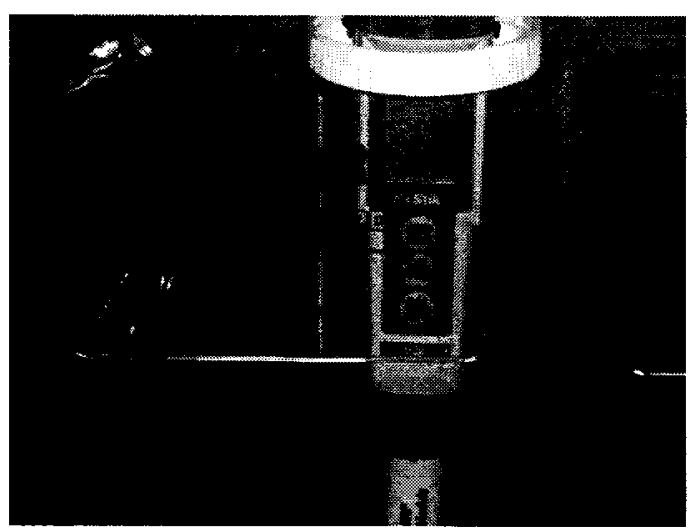

Figure 3.2 - ORP Testing of Polymer Solution 


\subsubsection{Phase 2 Polymer Testing}

After phase 1 polymer testing, eight polymers were selected for further testing. To simulate the thickening performance of each polymer, a bench scale gravity thickening device is used, which consists of a large screw-top plastic jar, which had the bottom cut off. The lid was modified by cutting a large hole, leaving only the threaded outside edge, and a small strip of plastic around the top. Inside the lid, a piece of belt material from the GBT was placed and glued into position using waterproof silicone, after which the top was refastened to the bottle. By inverting the bottle and pouring sludge onto the gravity belt material, the sludge may be thickened by gravity, as thickened solids collect on the surface of the gravity belt material, and liquid filtrate passes through the porous belt material, and can be collected in a beaker.

Each polymer solution was added to a sample of waste activated sludge, at a concentration of $4.5 \mathrm{~g}$ of polymer per $\mathrm{kg}$ sludge solids, which is equivalent to the average full-scale polymer concentration from June 2005 to June 2006. The sludge was characterized each day to ensure correct dosage. Because the WAS was found to be a relatively constant 0.8 percent solid at Crystal Beach WWTP, $36 \mathrm{~mL}$ polymer per litre of sludge was the approximate dosage used on most days. A summary of the sludge characteristics is shown in Table 3.1. The polymer and sludge were mixed using the same method outlined in Severin and Grethlein (1996), using $500 \mathrm{~mL}$ beakers to pour the mixture back and forth 10 times. $350 \mathrm{~mL}$ samples were used to ensure that sufficient surface area was exposed so that water could not pool on the surface during drainage (Severin et al., 1999). Samples were poured onto the gravity thickener and allowed to 
drain for 10 minutes. Testing was then performed on the separated solid and liquid phases. The thickening apparatus is shown below in Figure 3.3.

Table 3.1 - Summary of Sludge Characteristics at Crystal Beach WWTP:

\begin{tabular}{|l|l|l|l|l|}
\hline Sample Type & \multicolumn{2}{|l|}{ Activated Sludge } & \multicolumn{2}{l|}{ Waste Activated Sludge } \\
\hline Parameter & $\begin{array}{l}\text { Suspended Solids } \\
(\mathrm{mg} / \mathrm{L})\end{array}$ & $\begin{array}{l}\text { Volatile } \\
\text { Suspended Solids } \\
(\%)\end{array}$ & Total Solids (\%) & $\begin{array}{l}\text { Total Volatile } \\
\text { Solids (\%) }\end{array}$ \\
\hline Average & 3360 & 66 & 0.83 & 34 \\
\hline Standard Deviation & 758 & 11 & 0.15 & 3 \\
\hline
\end{tabular}

Methods for the tests performed were taken from Standard Methods (American Public Health Association, 1998). Solid phase testing included: total solids, total volatile solids, total phosphorous, total Kjeldahl nitrogen, ammonia nitrogen, and total five-day BOD. The same parameters were measured in the liquid samples except total volatile solids; in addition liquid samples were tested for total suspended solids and turbidity. Table 3.2 summarizes the parameters tested. Please see Appendix 2 for calculations related to analytical methods. 


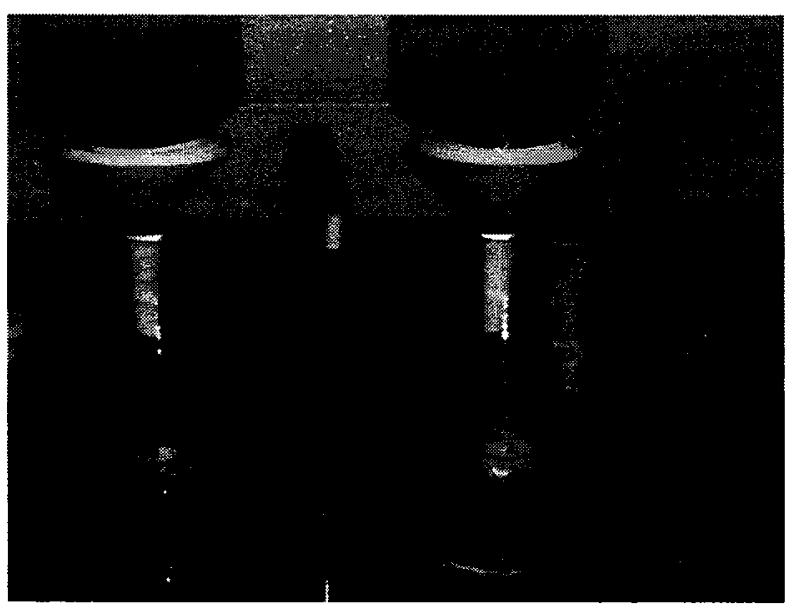

Figure 3.3 - Polymer Thickening Apparatus

Table 3.2 - Parameters for Polymer Screening Tests:

\begin{tabular}{|l|l|l|l|}
\hline Test & Units & $\begin{array}{l}\text { Performed on } \\
\text { Phases }\end{array}$ & Significance \\
\hline $\begin{array}{l}\text { Total solids } \\
\text { (TS) }\end{array}$ & $\%$ & Solid and liquid & $\begin{array}{l}\text { Thickening } \\
\text { effectiveness }\end{array}$ \\
\hline $\begin{array}{l}\text { Total suspended } \\
\text { solids (TSS) }\end{array}$ & $\mathrm{mg} / \mathrm{L}, \mathrm{mg} / \mathrm{kg}$ & Liquid & $\begin{array}{l}\text { Clarity of } \\
\text { supernatant }\end{array}$ \\
\hline $\begin{array}{l}\text { Total volatile } \\
\text { solids (TVS) }\end{array}$ & $\mathrm{mg} / \mathrm{L}, \mathrm{mg} / \mathrm{kg}$ & Solid & $\begin{array}{l}\text { Digestion } \\
\text { indicator }\end{array}$ \\
\hline $\begin{array}{l}\text { Total } \\
\text { Phosphorous (P) }\end{array}$ & $\mathrm{mg} / \mathrm{L}, \mathrm{mg} / \mathrm{kg}$ & Solid and liquid & Nutrient conc. \\
\hline $\begin{array}{l}\text { Ammonia } \\
\text { Nitrogen } \\
\text { (NH } \text { }_{3}\end{array}$ & $\mathrm{mg} / \mathrm{L}, \mathrm{mg} / \mathrm{kg}$ & Solid and liquid & Nutrient conc. \\
\hline $\begin{array}{l}\text { Total Kjeldahl } \\
\text { Nitrogen (TKN) }\end{array}$ & $\mathrm{mg} / \mathrm{l}, \mathrm{mg} / \mathrm{kg}$ & Solid and liquid & Nutrient conc. \\
\hline tBOD 5 & $\mathrm{mg} / \mathrm{L}, \mathrm{mg} / \mathrm{kg}$ & $\begin{array}{l}\text { Solid and } \\
\text { Liquid }\end{array}$ & $\begin{array}{l}\text { Regulatory } \\
\text { objective }\end{array}$ \\
\hline Turbidity & $\mathrm{NTU}$ & Liquid & $\begin{array}{l}\text { Clarity of } \\
\text { supernatant }\end{array}$ \\
\hline
\end{tabular}




\subsubsection{Total Solids Test}

Samples of approximately $20 \mathrm{~g}$ (for solids), or $20 \mathrm{~mL}$ (for liquids), were dried in ceramic crucibles at 105 degrees Celsius for 18 hours, allowed to cool in a desiccator to room temperature, and weighed on an electronic balance (Sartorius ${ }^{\mathrm{TM}}$ Model 1200s).

\subsubsection{Total Suspended Solids Test}

Whatman ${ }^{\mathrm{TM}}$ 934-AH glass fibre filter papers $(1.5 \mu \mathrm{m}$ aperture size), were removed from a dessicator and weighed on an electronic balance. Liquid samples of $100 \mathrm{~mL}$ were vacuum filtered through the filter papers using a Buchner funnel, and papers were rinsed with distilled water. The filter papers were then dried at 105 degrees Celsius for 18 hours, allowed to cool in a dessicator to room temperature, and weighed on an electronic balance.

\subsubsection{Total Volatile Solids Test}

After total solids testing, (see section 3.1.3.1), the contents of the crucibles were burned at 550 degrees Celsius for 2 hours, allowed to cool in a dessicator to room temperature, and weighed on an electronic balance. The difference in mass between the crucibles after total solids testing and the crucibles after burning is converted into a percentage, and reported as the percent total volatile solids (see Appendix 2). This test shows what percentage of the dried solids that are volatized at 550 degrees Celsius. 


\subsubsection{Total Phosphorous Test}

The total phosphorous test consists of a digestion phase in which phosphorous is converted to ortho-phosphate in a reaction with sulfuric acid, potassium sulfate and mercuric sulfate. Ortho-phosphate then reacts with ammonium molybdate and potassium antimony tartrate to form an antimony-phospho-molybdate complex. This complex is reduced by ascorbic acid, after which it exhibits a blue colour that can be identified by a spectrophotometer at $880 \mathrm{~nm}$ (Cheese, 2005).

For liquid samples, $12.5 \mathrm{~mL}$ of sample is diluted with $12.5 \mathrm{~mL}$ deinonized (DI) water. For solid samples, approximately $0.2 \mathrm{~g}$ of sample is weighed on an electronic balance, and mixed with enough DI water to make a sample of $25 \mathrm{~mL}$ total volume. Between four and six Hengar boiling stones are added to each test tube. $5 \mathrm{~mL}$ of digestion solution is added. The digestion solution is made by adding $650 \mathrm{~mL}$ DI water to a 1 liter flask, then adding $134 \mathrm{~g}$ of potassium sulphate, and $200 \mathrm{~mL}$ of sulfuric acid (97 percent concentration). While stirring, $25 \mathrm{~mL}$ of mercuric sulfate solution, (87.5 percent DI water, 12.5 percent sulphuric acid, $8.0 \mathrm{~g}$ mercuric oxide) is added. The solution is mixed on a vortex mixer and heated at 200 degrees Celsius in a digestion rack for 180 minutes, and then at 380 degrees Celsius for 60 minutes. Samples are cooled at 20 degrees Celsius for 30 minutes. Samples are brought back up to $25 \mathrm{~mL}$ with DI water, and mixed again on the vortex mixer. Solid samples are diluted by a factor of 10 after digestion. Samples are then transferred to $10 \mathrm{ml}$ autosampler tubes, and measured for absorbance at $880 \mathrm{~nm}$ using a Skalar 01- SAN Plus System- Model \# 4001 Segmented Flow Analyser. 


\subsubsection{Ammonia Nitrogen Test}

The ammonia nitrogen test uses chlorine to form monochloramine, which then reacts with salicylate to form 5-aminosalicylate. The solution is oxidized and forms a green coloured complex, which is measured for absorbance at $660 \mathrm{~nm}$, (Linkiewicz, 2005).

For liquid samples, approximately $10 \mathrm{~mL}$ of sample is poured into a $12 \mathrm{ml}$ autosampler tube. Solid samples are prepared by weighing $1 \mathrm{~g}$ of sample into a $50 \mathrm{ml}$ plastic tube using an electronic balance, and then adding $50 \mathrm{~mL}$ DI water, and 3 drops of sulphuric acid (97 percent concentration). Samples are then placed in a sonicator for 20 minutes, then filtered with a 0.45 micron filter. Samples are diluted by a factor of 10 prior to measuring absorbance.

\subsubsection{Total KjeldahI Nitrogen Test}

The Total Kjeldahl Nitrogen, (TKN) test employs a digestion phase identical to the one used in the total phosphorous test, (see section 3.1.3.4). Since TKN is equal to the amount of organic nitrogen plus ammonia, the reaction to form an oxidized 5aminosalicylate complex is also performed as in section 3.1.3.5

\subsubsection{Total Biochemical Oxygen Demand Test}

The $\mathrm{ABOD}_{5}$ test employs the Hach BODTrak apparatus. This equipment uses air tight sample containers equipped with pressure sensors. Samples are incubated for five days, and reductions in headspace pressure in the bottles are equated to oxygen uptake by 
microorganisms and chemical oxidation processes. To prevent inaccurate measurements, lithium hydroxide crystals are present below the pressure sensor to absorb carbon dioxide formed by the oxidation of organic matter (Hach Company, 2006). Since the equipment does not allow measurement of chemical oxygen demand early in the five day testing interval, the COD is not subtracted from the measurement, and the results are listed as total biochemical oxygen demand, not total biological oxygen demand.

Liquid samples were diluted by a factor of 10 by volume, while solid samples were diluted by a factor of 100 by weight using distilled water. Using a graduated cylinder, approximately $85.5 \mathrm{~mL}$ of sample were poured into sample bottles. Using a pipette, 9.5 $\mathrm{mL}$ of raw sewage influent of known $\mathrm{tBOD}_{5}\left(\sim 200 \mathrm{mg} / \mathrm{L} \mathrm{tBOD}_{5}\right)$ is inserted into each bottle. $0.5 \mathrm{~mL}$ of nutrient buffer is added (Hach Company product \# 1416066), to ensure optimal bacterial growth, and a $1 \mathrm{~cm}$ magnetic stir bar is inserted. Each sample container is capped with a rubber seal that includes a cup filled with lithium hydroxide crystals. Sample bottles are placed on magnetic stirrers, and sealed with pressure sensitive tops. The BODTrak unit and samples are incubated at 20 degrees Celsius for five days. A quality control sample is obtained by using a glucose-glutamic acid standard solution at 2 percent concentration. Samples are discarded if standard solution $\mathrm{tBOD}_{5}$ is not measured at $198 \pm 30.5 \mathrm{mg} / \mathrm{L}$, (American Public Health Association, 1998).

\subsubsection{Turbidity Test}

Turbidity tests were performed using the Hach $2100 \mathrm{P}$ portable turbidimeter. Liquid samples are swirled by hand, and approximately $15 \mathrm{~mL}$ of sample are poured into $20 \mathrm{~mL}$ 
glass sample cells that have been rinsed with DI water. Sample cells are placed in the turbidimeter, and turbidity measured. Quality control is established by using a $100 \mathrm{NTU}$ formazin calibration standard.

\subsubsection{Phase 3 Polymer Testing}

After phase 2 polymer testing, three polymers were tested further to determine appropriate polymer dosages for subsequent full scale testing.

The dosages used are described in Table 3.3

Table 3.3 - Polymer Concentrations for Phase 3 and Phase 4 Testing

\begin{tabular}{l|llllll}
\hline Dose & Control & 1 & 2 & 3 & 4 & 5 \\
\hline$\frac{g \text { polymer solids }}{\mathrm{kg} \text { sludge }}$ & 0 & 2.75 & 3.65 & 4.55 & 5.45 & 6.35 \\
\hline
\end{tabular}

The polymer was added to the sludge samples using a pipette, and the mixture was rapid mixed for 30 seconds at $300 \mathrm{rpm}$, then slowly mixed at $25 \mathrm{rpm}$ for 3 minutes on the jar test apparatus. After mixing, $500 \mathrm{~mL}$ of flocculated sludge was poured through the gravity filter, and allowed to drain for 10 minutes. The thickened solids and the collected filtrate were stored separately for testing.

Both solid and liquid phases were tested for total solids. The solid phase samples were also tested for total phosphorous and total Kjeldahl nitrogen. The liquid phase was tested for ammonia and total BOD (tBOD). Because of equipment limitations, only 4 liquid samples were tested for tBOD. The $3.65,4.55,5.45$, and $6.35 \mathrm{~g}$ polymer per kg sludge solids concentration samples were used for tBOD testing. 
A sample of filtrate was also collected after 12 seconds of drainage, and tested for turbidity. This test approximated the contact time that the sludge and polymer mixture achieves at full scale on the GBT.

\subsubsection{Polymer Full-Scale Testing}

Three polymer types, (including the incumbent), were selected for two-week trials at fullscale. Samples of the thickened sludge and the filtrate from the thickening process were tested weekly for the parameters listed in Table 3.2. In this segment of testing, the polymer solutions are mixed automatically using tap water. The temperature of the mix water was not controlled at this point, but batches of polymer solutions were mixed at least 12 hours before testing, and kept at stored at room temperature, approximately 20 degrees Celsius.

\subsubsection{Description of Thickening Process at Crystal Beach WWTP}

At Crystal Beach, the GBT is the device used to thicken WAS, primarily because of its ease of operation and its ability to thicken automatically, with minimal operator supervision. The unit uses a variable speed belt with $200 \mu \mathrm{m}$ aperture, which is capable of accepting up to $80 \mathrm{~m}^{2}$ of WAS per hour. Typically, the unit is operated at a flow rate of approximately $60 \mathrm{~m}^{2}$ per hour, for 0 to 6 hours per day. The WAS is first conditioned using a cationic polymer that increases the effectiveness of the thickening process. The WAS is mixed with an aqueous polymer solution by turbulence in a cylindrical 
headstock, and the flocculated sludge overflows the headstock and is spread over the belt. Typically, flocculated sludge spends approximately 8 to 10 seconds on the belt, travelling 3.5 meters before being conveyed by gravity into an outlet hopper that uses thickened waste activated sludge pumps to pump the thickened sludge to the anaerobic digester.

Sampling from the GBT was done by hand, using $500 \mathrm{~mL}$ plastic jars. Thickened sludge was collected from the GBT outlet hopper, while filtrate was sampled using a $2.5 \mathrm{~m}$ metal sampling pole to which the sampling jars were attached. The filtrate sampling is shown in Figure 3.4.

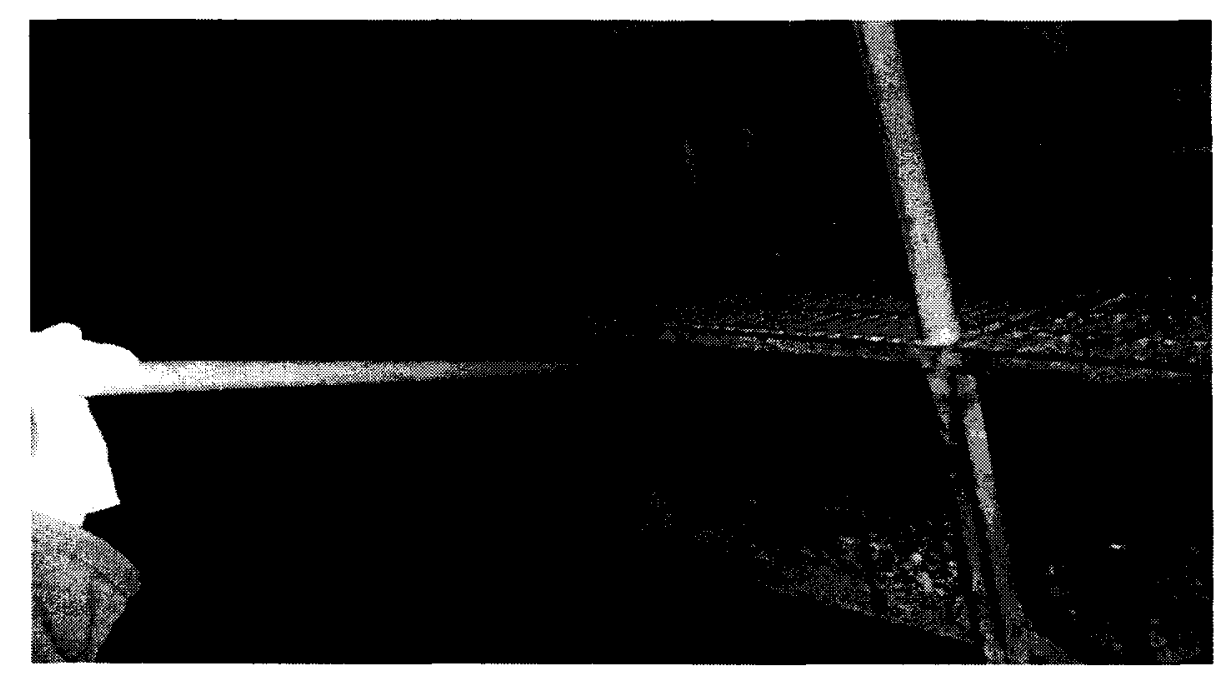

Figure 3.4 - Full-scale Filtrate Sampling

\subsubsection{Total Phosphorous Test}

During full-scale testing, the PhosVer $3^{\mathrm{TM}}$ with acid persulfate digestion method was used for liquid samples of GBT filtrate (Hach Company method 8190). Samples were diluted by a factor of five, and $5 \mathrm{~mL}$ of diluted sample was inserted into glass test vials. Potassium persulfate pillows, (Hach product 20847-66), were emptied into each vial, and vials capped and shaken to mix contents. Vials were incubated at 150 degrees Celsius in 
a DRB 200 reactor for 30 minutes, and then cooled to room temperature. Using a pipette,

$2 \mathrm{~mL}$ of $1.54 \mathrm{~N}$ sodium hydroxide is added to each sample, and vials are capped and shaken. Vials are placed into Hach DRB 2800 spectrophotometer analyzer unit cell holder, and zeroed. The contents of one PhosVer ${ }^{\mathrm{TM}}$ powder pillow, (Hach product 21060-46), are added, and vials capped and shaken for 15 seconds. After a three minute reaction period, vials are placed into analyzer cell holder. The results are expressed in $\mathrm{mg} / \mathrm{L} \mathrm{PO}_{4}{ }^{3-}$.

\subsubsection{Ammonia Nitrogen Test}

The Nessler method for nitrogen ammonia analysis was used during full-scale testing, (Hach method 8038). A $25 \mathrm{~mL}$ mixing graduated cylinder was filled with sample, and three drops of mineral stabilizer (Hach product 23776-26), were added to complex hardness. The cylinders were sealed with stoppers, and inverted four times to mix contents. Three drops of polyvinyl alcohol were added to each sample, (Hach product 23765-26), and samples mixed once more by inverting four times. Using a pipette, $1 \mathrm{~mL}$ of Nessler reagent, a $0.09 \mathrm{~mol} / \mathrm{L}$ solution of potassium tetraiodomercurate(II) $\left(\mathrm{K}_{2}\left[\mathrm{HgI}_{4}\right]\right)$ in $2.5 \mathrm{~mol} / \mathrm{L}$ potassium hydroxide, (Hach product $21194-49$ ), is inserted into each sample, and cylinders are sealed and inverted four times to mix. After a one-minute reaction period, samples are placed in Hach DRB 2800 spectrophotometer analyzer cell holder, and measured for ammonia concentration. Each sample is measured directly after a DI water blank containing the same reagents, used to zero the meter. 


\subsection{Foam Control}

\subsubsection{Microbial Identification}

To determine the composition of the clarifier foam, a sample is obtained from the clarifier and examined under a compound binocular laboratory microscope. Samples are collected from the clarifier surface using a $500 \mathrm{~mL}$ polyethylene terephthalate (PET) plastic sample container. Samples of clarifier foam were collected in June, August, October, and December, to determine whether the dominant species remain so over time. Samples were also obtained from other points in the process stream, to understand how filamentous bacteria may be surviving, proliferating, and possibly reintroduced into the activated sludge system. Samples of raw influent from the headworks of the plant, from the waste activated sludge storage tanks, from the return activated sludge system, and from the sludge thickening filtrate, (which is sent to the aeration basins for treatment), were all examined.

Samples were examined at 100 times magnification for initial characterization of representative bacteria. Each sample was then stained using the crystal violet gramstaining method: After using a dropper to deposit approximately $1 \mathrm{~mL}$ of foam sample on slide, the slides were warmed at 40 degrees Celsius for approximately five minutes. The slides were then flooded with crystal violet solution $(2 \mathrm{~g}$ crystal violet dissolved in $20 \mathrm{~mL}$ ethanol, mixed with $0.8 \mathrm{~g}$ ammonium oxalate dissolved in $80 \mathrm{~mL}$ distilled water) and rinsed with distilled water. Slides were then flooded with Lugol's Iodine $(2 \mathrm{~g}$ potassium iodide and $1 \mathrm{~g}$ iodine crystals dissolved in $100 \mathrm{~mL}$ distilled water), and rinsed again with distilled water. A three-second rinse with acetone was then performed to 
decolourize the slides, and then they were counter-stained using a wash of saffranin red (0.25 g saffranin $\mathrm{O}$ powder dissolved in $10 \mathrm{~mL}$ ethanol, mixed with $90 \mathrm{~mL}$ distilled water). After staining, the slides were re-examined at 100 times magnification, then examined again at 1000 times magnification using an oil mount objective lens.

\subsubsection{Microbial Enumeration}

To determine the concentration of $E$. coli culture forming units (cfu) in the foam, the Colilert ${ }^{\mathrm{TM}}$ system was used. This system uses a substrate that contains a combination of salts, nitrogen, and carbon sources designed specifically as a substrate for coliform bacteria. When metabolized by $E$. coli, a compound is released that fluoresces in the presence of UV light. Samples were well mixed with $10 \mathrm{~mL}$ distilled water, and placed in reactor tubes, which were pre-filled with fluorescent reagent. The tubes were mixed vigorously, and incubated at 35 degrees Celsius for 24 hours. After incubation, the tubes were observed under natural and UV light. By counting the number of fluorescent tubes under UV light, and comparing with a table of values, a 95 percent confidence level range was identified for the concentration of $E$. coli.

\subsubsection{Process Adjustment}

To prevent filamentous bacteria from existing in sufficient numbers to cause foaming problems, numerous areas requiring adjustment were identified: 1.) The SRT maintained in the activated sludge system. 2.) The F/M ratio range that was typical at the plant. 3.) The possibility of foam trapping occurring between the aeration cells and clarifiers. 
Areas 1.) and 3.) were specifically identified for further investigation. To control the SRT, the plant will automate the sludge wasting and return processes. In other words, the sludge wasting and return valves at the plant will be operated automatically by computerbased process control logic. This will ensure that the plant operates at a consistent SRT that may be adjusted in order to make it more difficult for filamentous bacteria to survive. Two out of four clarifiers will be taken out of service, which will lower the SRT by causing the total plant flow to progress through the plant more quickly. To understand how foaming may be affected by the physical character of the activated sludge passage from the aeration system to the clarification system, a baffle wall will be installed on one of two clarifiers to show how foam trapping may play a role in the sludge separation problem. To prevent foam from becoming more concentrated in trapping areas, a surface spray system was tested. This system was made using four segments of garden hose that had showerheads at their ends to allow a diffuse spray to contact the foam surface. The hose segments were attached to a plastic cylinder that could be opened to insert a chlorine puck. This allowed testing to determine the relative difference between a pure water spray and a chlorinated water spray. The results from the trial of the spray system are presented in Appendix 3. 


\section{Results}

\subsection{Polymer Testing}

\subsubsection{Pre Screening (Phase 1)}

As discussed in Section 2.1.2, the purpose of sludge conditioning is to coagulate sludge particles by neutralizing the charge, and/or enhance floc formation by entangling sludge particles (Dentel, 2001). In this study, the oxidation-reduction potential (ORP) of the aqueous polymer solutions is measured in order to characterize the electrochemistry of the polymer solutions. Using an ORP test allows measurement of the ability of a solution to act as an electron donor or acceptor, and so an estimation of the ability of a polymer to neutralize charged sludge particles may be made. Electron acceptors, such as cationic polymers, should have positive ORP values, while electron donors, such as negatively charged sludge particles in WAS, should have negative ORP values (Atkins and Jones, 2005). The results from the ORP testing are shown in Figure 4.1. The data shows the mean values of three trials $(n=3)$, plus or minus one standard deviation. The data showed that all polymer solutions had mean oxidation-reduction potentials between 190 and 280 millivolts. It is clear that there is significant variability in the data among different polymer types, but nonetheless, it seems that some polymer solutions may be characterized by larger oxidation-reduction potentials (e.g. CIBA 8160), while others have relatively lower oxidation-reduction potentials (e.g. SNF 4190). In theory, the polymers which have high ORP values in solution are those that have a high molecular weight and/or charge density, and so produce a solution with greater transferability of charge (Atkins and Jones, 2005; Dentel, 2001). Conversely, the polymers with low ORP 
values in solution should theoretically have lower molecular weight and/or charge. For example, polymers CIBA 8160 and EC 4925 produced solutions with the highest observable ORP values. These polymers are high molecular weight, high charge density, and are specialized for conditioning of biological sludge. Polymer EC 4925 is commonly used to condition activated sludge from slaughterhouses, which is typically difficult to dewater relative to domestic wastewater sludge (Al Mutairi et al., 2004). Lower ORP polymers, such as SNF 4290 are mainly lower charge density polymers commonly used in domestic wastewater applications. See Appendix 4 for a summary of the charge density and molecular weight characteristics of the polymers. The eight polymer types selected for screen testing, (listed with asterisks in Figure 4.1), have a range of ORP values, and were selected to give an approximate cross-section of the larger group. The group of selected polymers also contain at least one representative from each of the polymer supply companies that furnished samples for this study. The charge density of the eight polymers range from low to high, while the molecular weights range from medium to very high. 


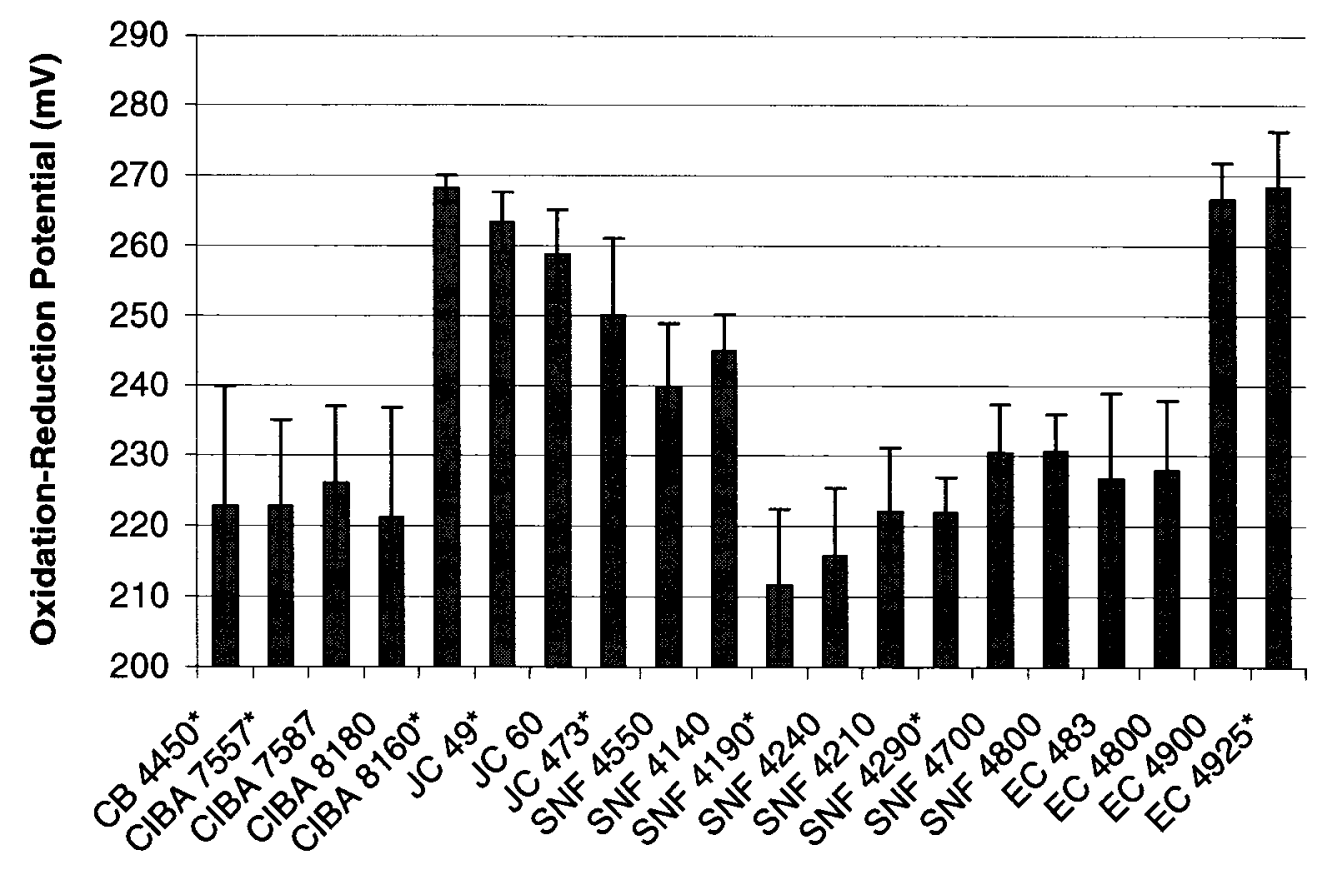

Polymer Solutions $(0.1 \%$ concentration, $n=3)$

Figure 4.1 - Polymer Solution Oxidation-Reduction Potential \pm 1 Standard Deviation

\subsubsection{Polymer Testing - Screen Test (Phase 2)}

After pre-screening, eight polymers were used for the second phase of testing. This section shows the results of testing of solid samples (i.e. thickened sludge), and liquid samples (i.e. filtrate from the thickening process). Solid samples were tested for percent total solids, percent volatile solids, TKN concentration, total phosphorous concentration, and total BOD concentration. Liquid samples were tested for percent total solids, ammonia concentration, TKN concentration, and total phosphorous concentration. Figures 4.2 to 4.9 summarize the results. Each chart shows polymers listed by company name and model number, and includes a control sample (which was sludge that was 
thickened without adding polymer to condition the sludge) and a sample from the fullscale GBT apparatus (labelled GBT). Polymer CB 4450 is shown on the left-hand side of all graphs, and is the incumbent polymer that was being used full-scale at the time of testing. All graphs show the average of two samples $(n=2)$, and show the results of polymers being applied at a dosage of $4.5 \mathrm{~g}$ polymer per kilogram sludge solids. The data, including maximum and minimum values for each data series are presented in Appendix 7, section A7.1. Further information on the preparation of data can be found in Appendix 5.

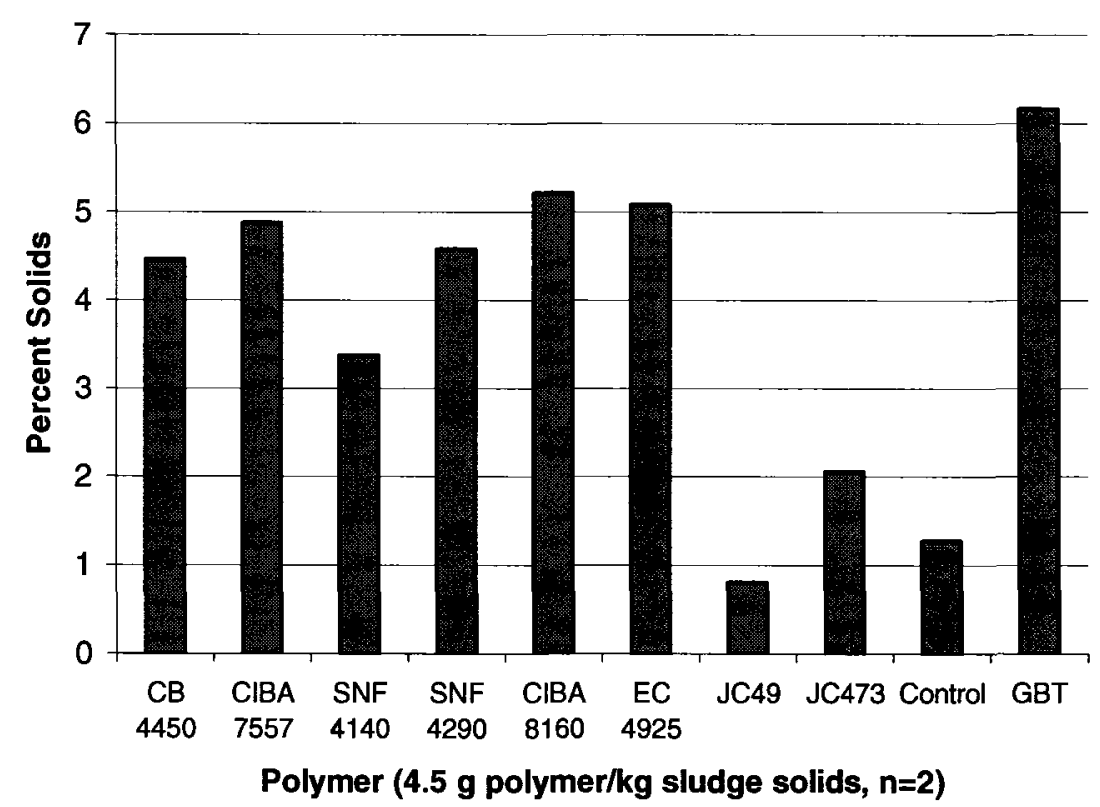

Figure 4.2 - Thickened Sludge Percent Total Solids

Figure 4.2 shows the percent total solids measured of each thickened sludge sample at bench scale. This test measures the mass of thickened sludge samples before and after drying, and thus reveals the amount of dry solids in the thickened sludge. The goal of thickening in this application is to produce thickened sludge that is between 
approximately 4 and 6 percent total solids. The data shows that most polymers provide thickened sludge of higher total solids content than the control sample, which contained no polymer. The notable exceptions are the JC 49 and JC 473 polymers, which do not improve thickening relative to the control sample, and produced thickened sludge well below the required 4 to 6 percent total solids range. This may be because the JC polymers were not applied at a high enough dosage to condition sludge properly for thickening. The CIBA polymers produced thickened sludge with relatively high levels of total solids, approximately 5 percent, but the results observed also contain relatively high variability. SNF 4290, CB 4450, and EC 4925 all produced thickened sludge with over 4 percent total solids content, and were less variable in performance than others were. At bench-scale, five of the eight polymers produced thickened sludge within the target range of 4 to 6 percent total solids, one polymer produced sludge slightly below this range, (approximately 3.5 percent total solids), and two polymers produced thickened sludge significantly below this range, (approximately 1 percent total solids). So there do seem to be some distinct advantages in solids capture provided by some polymers. This means that some polymers provide a combination of charge neutralization and interparticle bridging that allow for proper thickening to occur. Other polymers may be better suited to different WWTP sites and/or different types of thickening apparatus. Also, it is notable that one of the most effective polymers in this test, EC 4925, and one of the least effective polymers in this test, JC 49, were both among the very highest in ORP values in phase one testing. Thus, the ORP test as performed appears not to be useful for gauging the solids capture performance of polymers in this context. It is also notable that the fullscale GBT performs better than the bench-scale GBT using the incumbent polymer (CB 
4450). The bench-scale apparatus delivers thickened sludge of approximately 4.5 percent total solids, while the full-scale GBT delivers thickened sludge of approximately 6 percent total solids, a 33 percent difference. This suggests that the bench-scale testing is likely to underestimate the performance of a given polymer. There are various reasons why this may be. One is that on the full-scale GBT, thickened sludge collects at the outlet end, increasing the retention time that sludge achieves on the belt. The thickened sludge also piles up, which may cause pressure at the belt surface, increasing the compressive force that the sludge undergoes. Because of this, during full-scale trials, sludge is sampled from the belt immediately before the outlet where the sludge piles up.

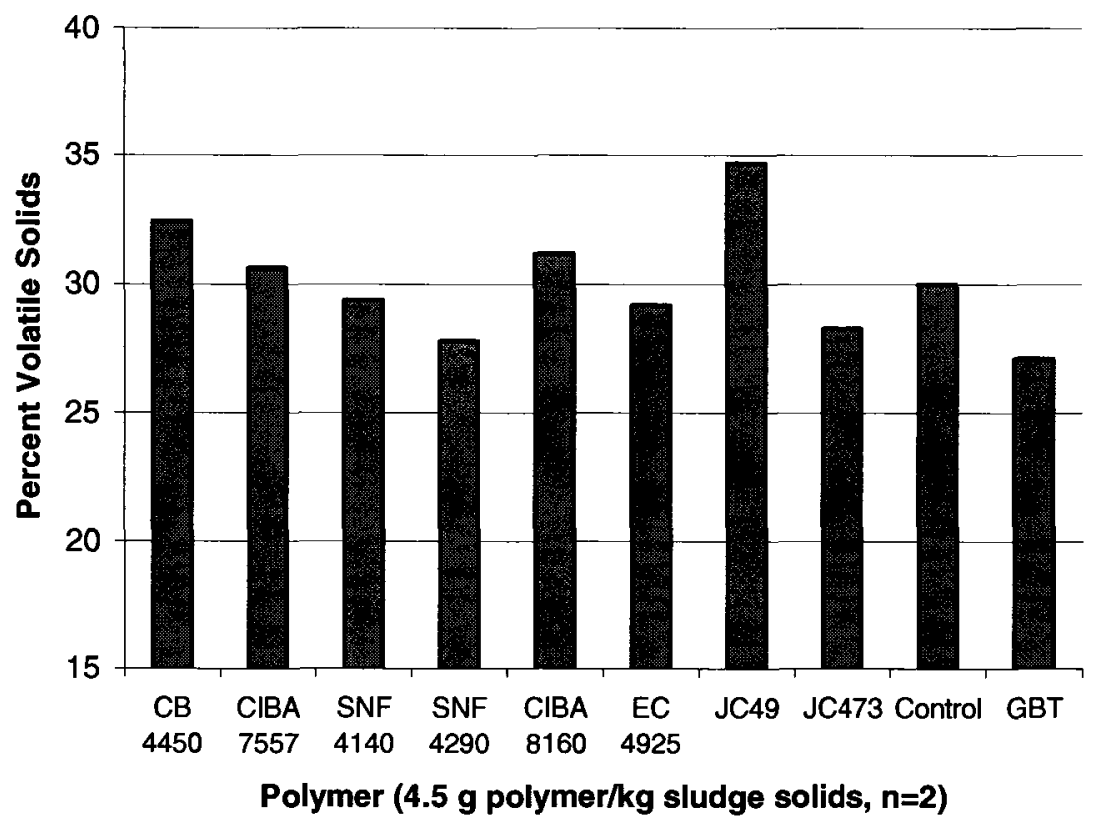

Figure 4.3 - Thickened Sludge Percent Volatile Solids

Figure 4.3 shows the volatile solids concentration of thickened sludge. This test reveals the percentage of mass of dried sludge that is volatized at 550 degrees Celsius. This 
value approximates the amount of organic matter in the dried sludge. Because the thickened sludge will be introduced to further biological treatment, (i.e. digestion), and organic matter within the sludge may be used as substrate for the microorganisms in this process, the TVS measurement allows us to characterize how much substrate may be available for the digestion process (Droste, 1997). The results show that all thickened sludge samples were measured to be within one standard deviation of approximately 30 percent volatile solids. The full-scale GBT produced thickened sludge with a very high variability, and so perhaps the thickened sludge is naturally variable in volatile solids content, or perhaps the method used to measure volatile solids is imprecise. In these experiments, the amount of thickened sludge that could be collected in the bench-scale apparatus was tested for 8 different parameters, and so only a small amount (less than 0.1 kg) was used for TS and TVS testing. Perhaps with larger sample sizes, less variable results may have been achieved. However, due to the variability observed, the percent volatile solids of thickened sludge was not used as a selection parameter for subsequent testing. 


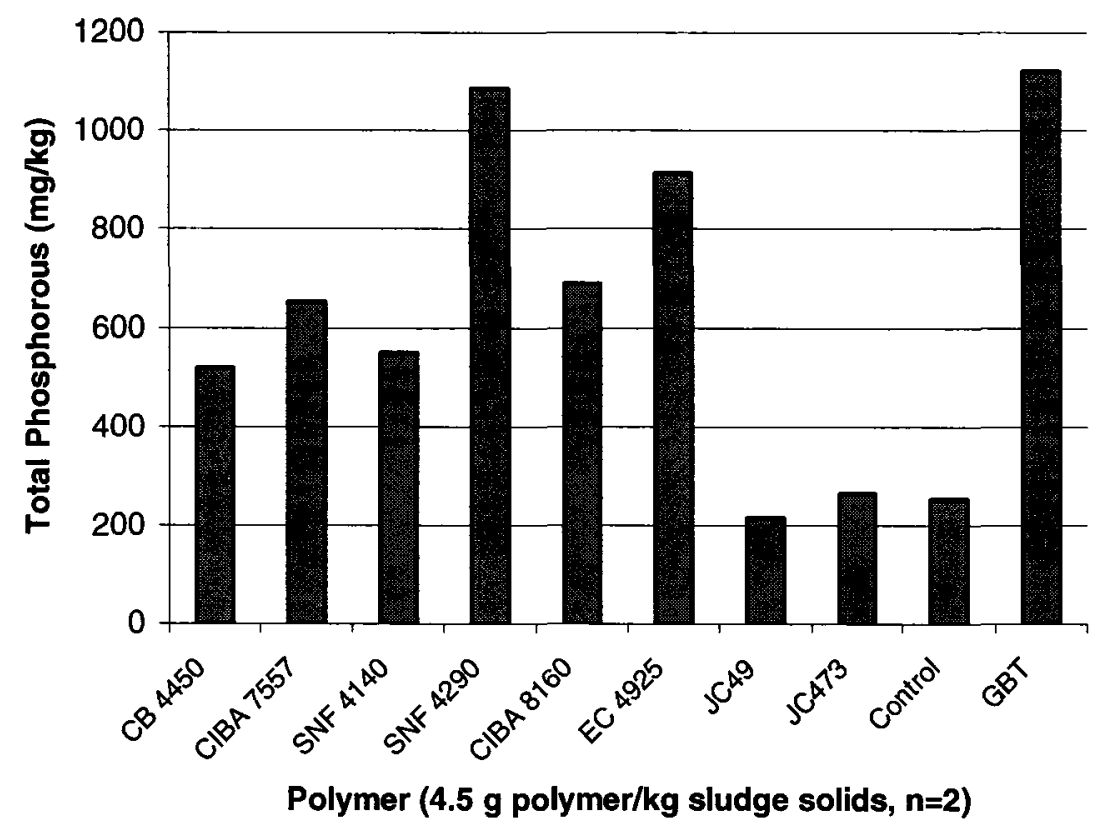

Figure 4.4 - Total Phosphorous Content of Thickened Sludge

The total phosphorous concentration in thickened sludge is shown in Figure 4.4. Polymer SNF 4290 produced thickened sludge with a total phosphorous concentration of approximately $1100 \mathrm{mg}$ total phosphorous per $\mathrm{kg}$ of thickened sludge, and polymer EC 4925 produce thickened sludge with approximately $900 \mathrm{mg} / \mathrm{kg}$ total phosphorous. With the exception of JC 49 and JC 473, the other polymers delivered thickened sludge with a total phosphorous concentration between 500 and $700 \mathrm{mg} / \mathrm{kg}$. The full-scale GBT value shown above represents only one sample tested. The GBT sample was measured to be highest in total phosphorous content at $1125 \mathrm{mg} / \mathrm{kg}$. This data suggests that some polymers do offer an advantage in nutrient selection. Polymer SNF 4290 produced thickened sludge at bench-scale with approximately twice as much total phosphorous as the incumbent polymer, CB 4450, while polymers JC 49 and JC 473 produced thickened sludge with about half of the concentration of total phosphorous relative to the incumbent 
polymer. The differences observed in total phosphorous in thickened sludge between the bench-scale and full-scale applications may be due in part to the higher percent total solids found in the full-scale thickened sludge (approximately 33 percent higher total solids in the GBT samples), since the sludge solids are the source of nutrient chemicals such as total phosphorous in WAS. So we should expect that the total phosphorous concentration of the thickened sludge should be higher when the solids content is higher. This dependence on solids content is discussed further in Section 4.2.1.

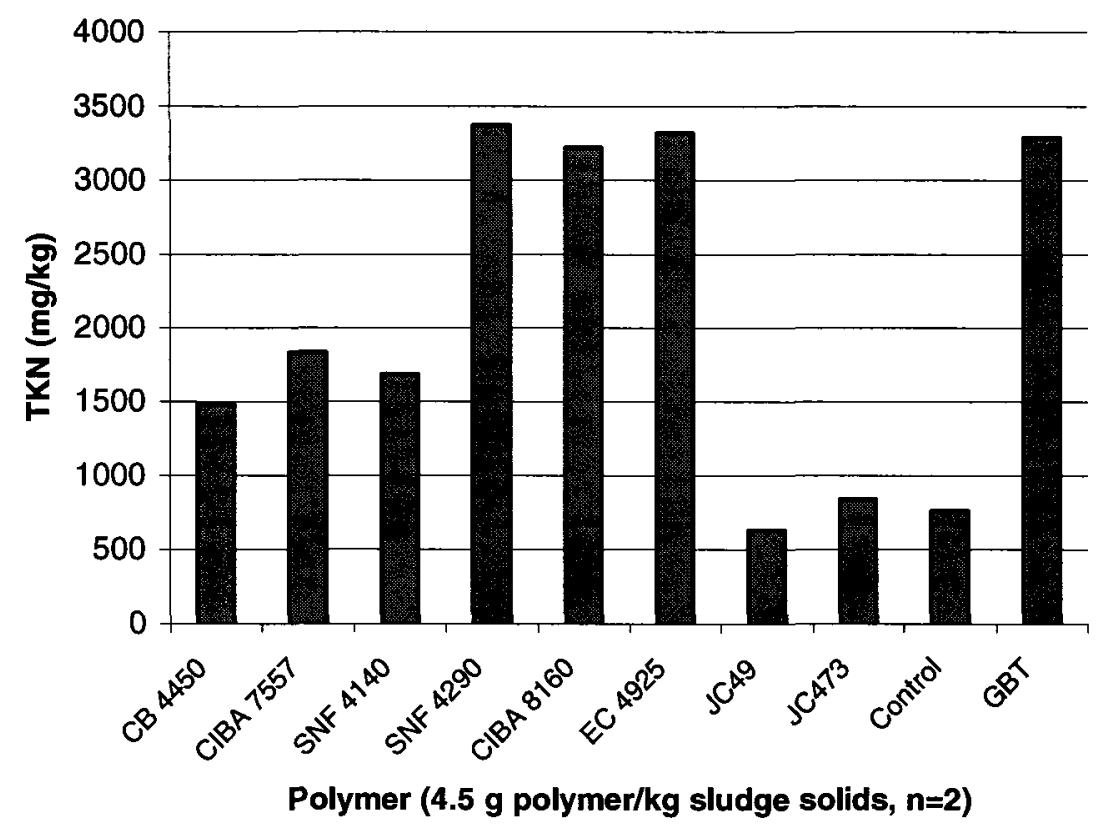

Figure 4.5 -Total Kjeldahl Nitrogen Content of Thickened Sludge

The TKN content of the samples is shown in Figure 4.5. The TKN content is an important parameter in this study, because this form of nitrogen appeared to be much more significant than ammonia nitrogen in the characterization of solid samples. Most samples had ammonia nitrogen contents that were very similar in magnitude, and very 
close to the lower detection limit of the lab tests, which is $30 \mathrm{mg}$ ammonia nitrogen per kilogram solids. For all solid samples tested the TKN concentration was over $500 \mathrm{mg} / \mathrm{kg}$, and so the concentration of TKN greatly outweighs the concentration of ammonia nitrogen in this case. Since organic nitrogen is equal to the TKN value minus the ammonia nitrogen value, TKN is a good estimator of organic nitrogen in this context. The TKN concentration results are similar to the total phosphorous results observed in Figure 1.5. The full-scale GBT value shown above represents only one sample tested. Polymers SNF 4290 and EC 4925 produce thickened sludge with relatively high levels of TKN compared to other polymer types, and exhibit less variability. Thus, this data also suggests an advantage in nutrient selection. Polymers SNF 4290, CIBA 8160, and EC 4925 concentrate approximately twice as much $\mathrm{TKN}$ in thickened sludge relative to $\mathrm{CB}$ 4450. We may note, again, that the comparison of relative polymer performance with respect to nutrient concentrations is somewhat similar to a comparison of total solids concentrations. In other words, thickened sludge with higher nutrient concentrations seems to be due in part to a higher total solids concentration. A comparison of total solids concentration and nutrient concentration does yield some interesting information, however. With respect to total phosphorous concentration, polymers SNF 4290 and EC 4925 produce thickened sludge with higher total phosphorous concentration compared to other polymers which perform about as well with respect to total solids, (such as CB 4450 and CIBA 7557). With respect to TKN, SNF 4290, EC 4925, and CIBA 8160 all out-perform polymers with similar solids capture. Since SNF 4290 and EC 4925 offered advantages in both phosphorous and ammonia concentration, they were selected as the strongest candidates for full-scale trials. 


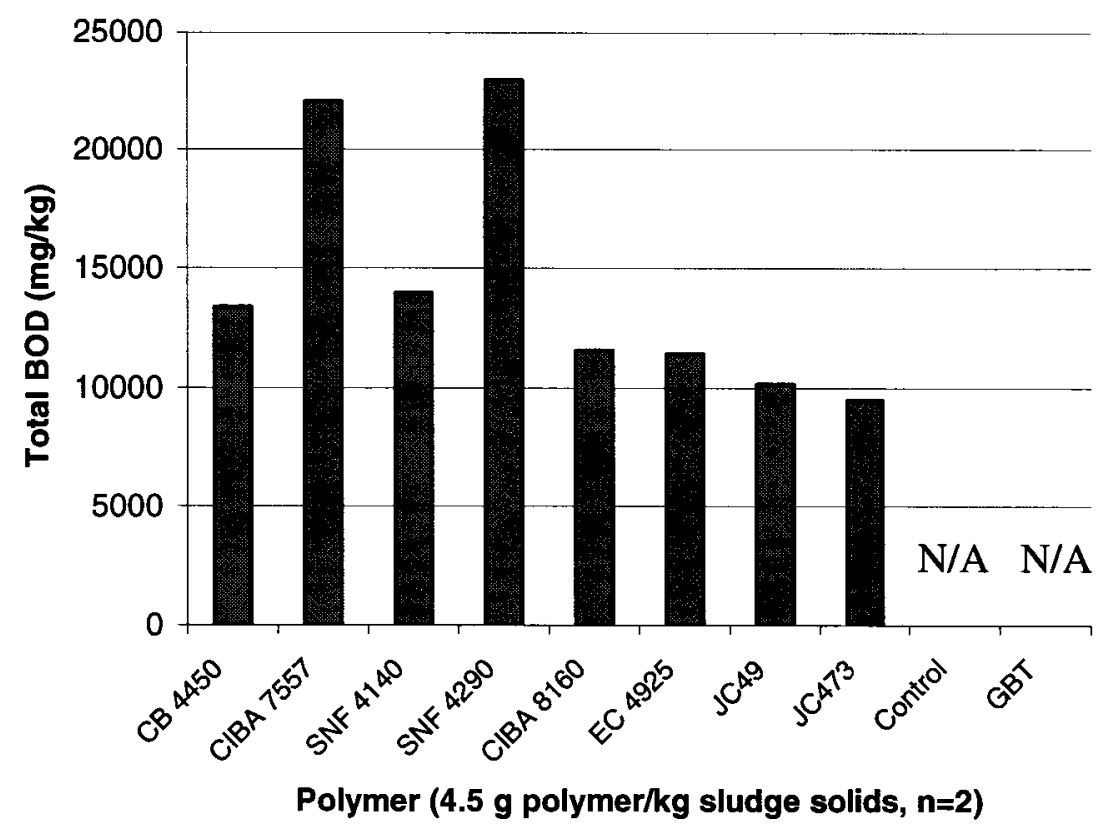

Figure 4.6 - Total BOD of Thickened Sludge

The total BOD of the thickened solid samples is shown in Figure 4.6. This test shows the amount of oxygen that is consumed by biological and chemical processes over a five-day period. This parameter measures the potency of wastewater, in terms of its ability to affect an aquatic environment. High BOD wastewater is thus potent in its ability to remove oxygen from an aquatic environment, which can greatly degrade habitat for aerobic aquatic organisms such as fish (Metcalf and Eddy, 2003; Droste 1997). Therefore, producing thickened sludge with high BOD is desirable compared to allowing it to persist in the liquid stream of the plant. Since removing BOD from wastewater is one of the primary goals of wastewater treatment in general, (Metcalf and Eddy, 2003; Droste, 1997), selecting polymers that concentrate the components that contribute to the $\mathrm{BOD}$ in waste sludge more efficiently can improve the overall effectiveness of the treatment process. This test revealed that polymers SNF 4290 and CIBA 7557 produce 
thickened sludge with approximately 75 percent higher tBOD than other polymer types. Because of resource and time constraints, control and GBT samples were not included in the tBOD analysis. The data from polymer CB 4450 and CIBA 7557 represents only one trial; the other samples were improperly preserved. This data shows some definite advantages in choosing one polymer over another with respect to tBOD. Most polymers deliver thickened sludge with approximately 10 to 15 grams of tBOD per kilogram sludge, including JC 49 and JC 473, which performed poorly in other tests. Polymers CIBA 7557 and SNF 4290, however, deliver thickened sludge with over 20 grams tBOD per kilogram.

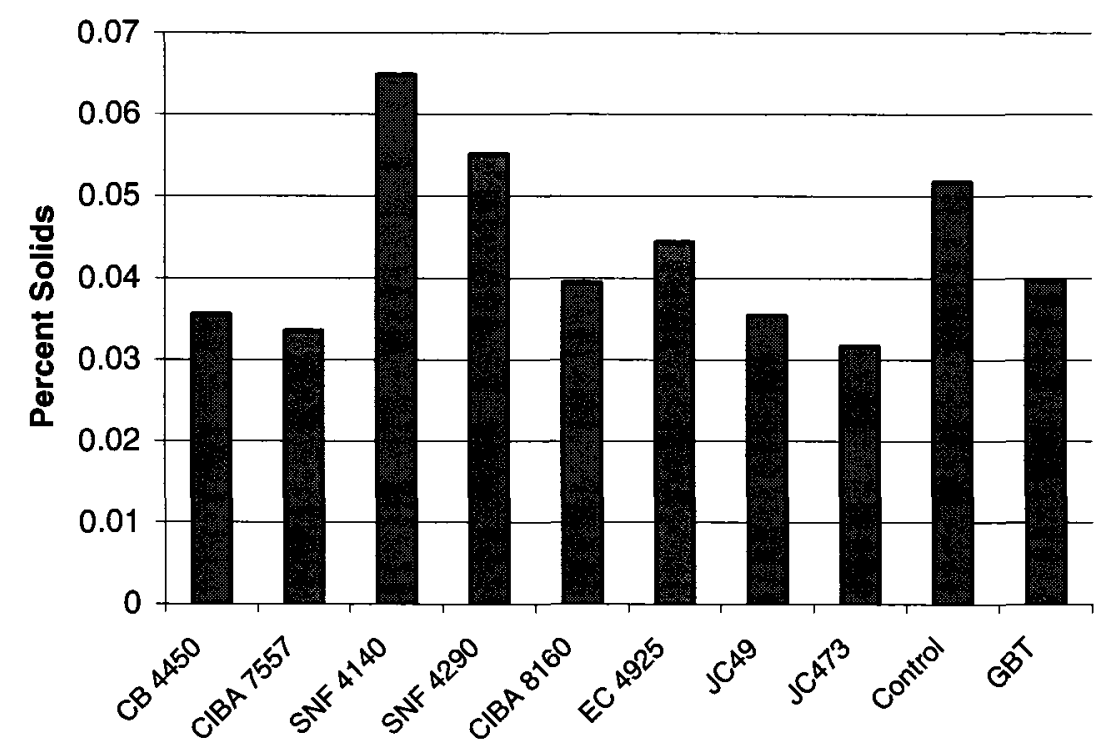

Polymer (4.5 $\mathrm{g}$ polymer $/ \mathrm{kg}$ sludge solids, $\mathrm{n}=2$ )

Figure 4.7 - Filtrate Percent Total Solids

Figure 4.7 shows the percent total solids found in filtrate samples. This parameter characterizes the amount of total solids in the filtrate, and thus shows what quality of filtrate is produced by the GBT. All samples that had lower percentages of total solids 
than the control sample had standard deviations of at least 25 percent of mean values. Since it should be expected that most polymers would produce filtrate with significantly lower total solids content than the control, it is possible that this data has a high experimental error associated with it. Since the filtrate percent solid values are around 0.05 percent, we are measuring very small amounts of total solids in these samples. To achieve better results, a larger amount of filtrate may have been beneficial, but the crucibles used to dry the samples had a capacity of approximately $0.1 \mathrm{~L}$. Essentially, the equipment used to measure total solids is designed for solid samples with high total solids (such as thickened sludge samples), as opposed to samples which characteristically are mostly liquid (such as filtrate samples). Therefore, to accurately measure filtrate total solids, higher capacity crucibles that can be used to dry larger samples would be useful. Because of the high variability observed, this parameter was not considered when selecting polymers for subsequent testing. 


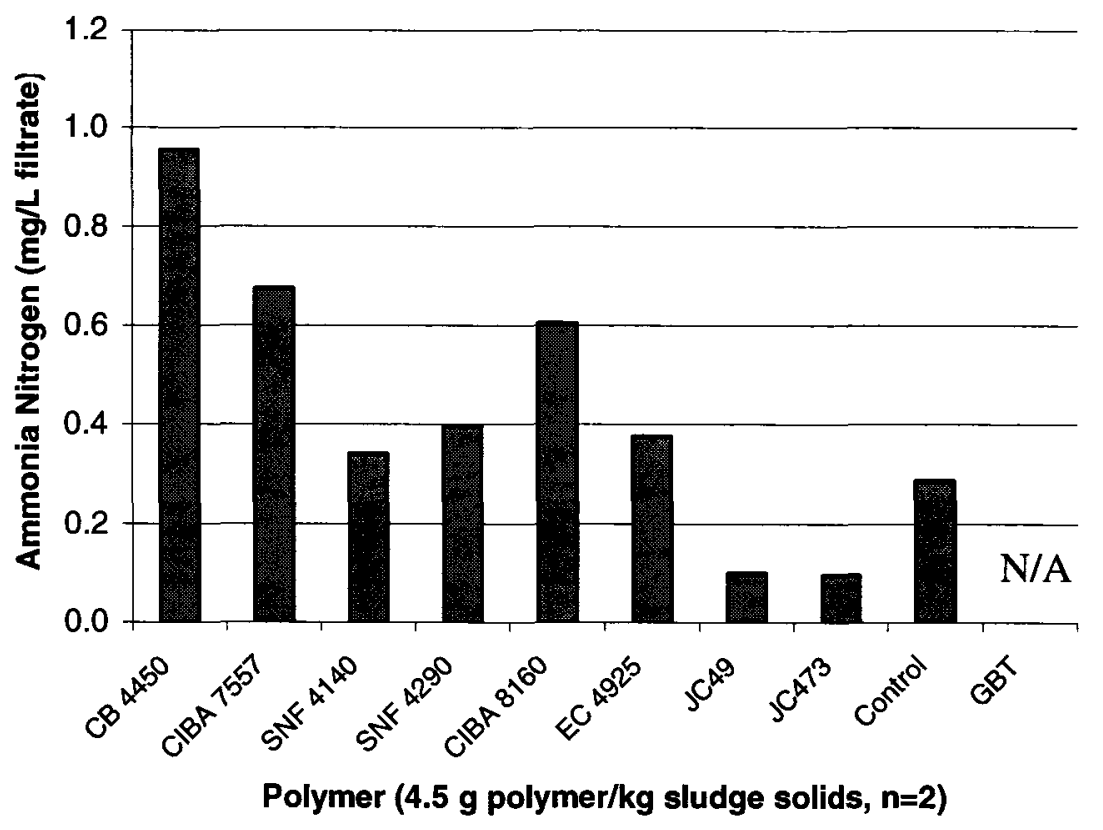

Figure 4.8 - Concentration of Ammonia in Filtrate

Figures $4.8,4.9$, and 4.10 show the concentration of ammonia, TKN and total phosphorous in filtrate, respectively. Characterizing the concentration of nutrient chemicals in the filtrate is important because filtrate is recycled back through the plant to be retreated. Thus, polymers that produce filtrate with relatively lower concentrations of nutrient chemicals will be desirable. Figure 4.8 shows the concentration of ammonia in the filtrate. The variability observed may be due in part to the variability observed in the solids concentration of the filtrate. The solids tested for ammonia nitrogen all had concentrations near or below the lower limit of the testing equipment of $30 \mathrm{mg} / \mathrm{kg}$ thickened solids. This is highly concentrated in ammonia compared to the filtrate, as no average concentration of filtrate for any polymer exceeded $1.0 \mathrm{mg}$ ammonia/liter filtrate. Therefore, it seems that even small changes in total solids percentage of filtrate may result in large differences in the concentration of ammonia measured in the filtrate. A 
study focused specifically on the removal of nutrient chemicals from the filtrate of thickening processes may benefit from tighter control of conditions to isolate the effects of polymers on nutrient concentrations in liquid streams. The variability in the data, particularly the relatively high variability associated with the control sample, makes it difficult to choose polymer types based on the filtrate ammonia data.

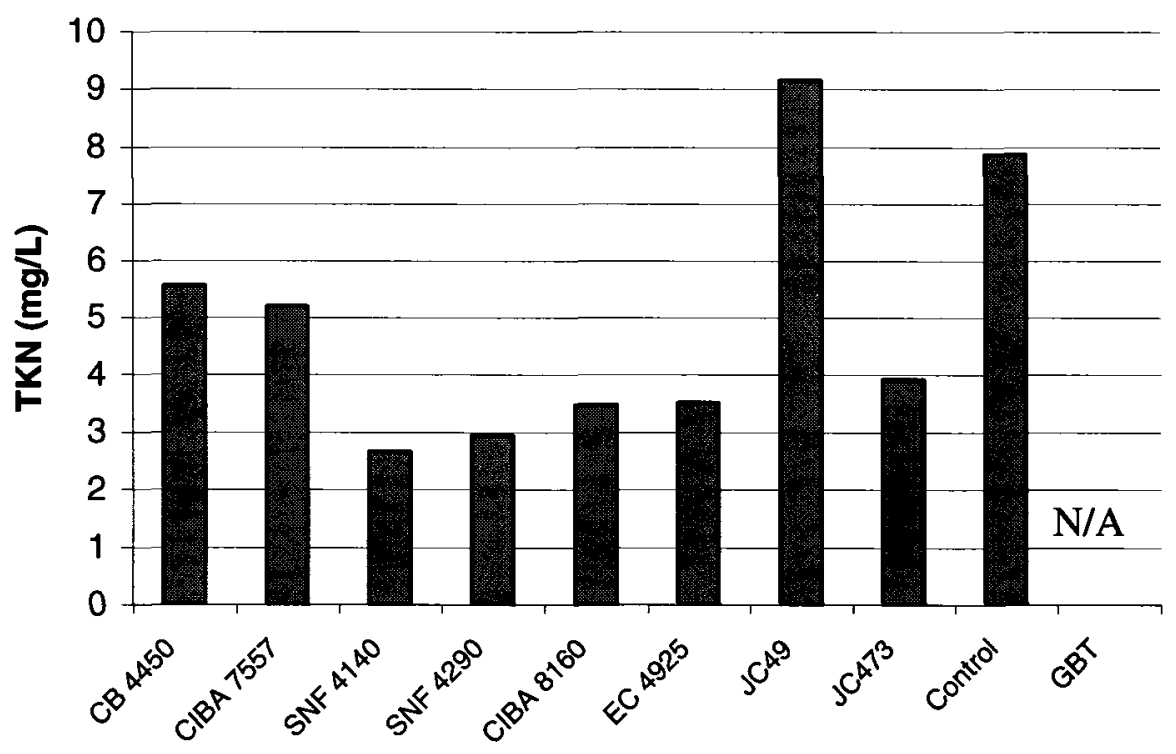

Polymer (4.5 g polymer/kg sludge solids, $\mathrm{n}=2$ )

Figure 4.9 - Concentration of TKN in Filtrate

The data in figure 4.9 shows that the SNF polymers lower the TKN concentration in the filtrate to approximately $3 \mathrm{mg} / \mathrm{L}$ versus the control sample, which averages about $8 \mathrm{mg} / \mathrm{L}$ TKN. CIBA 8160 and EC 4925 produce filtrate below $4 \mathrm{mg} / \mathrm{L} \mathrm{TKN}$, while CB 4450 and CIBA 7557 produce filtrate between 5 and $6 \mathrm{mg} / \mathrm{L} \mathrm{TKN}$, within one standard deviation of the control sample. 


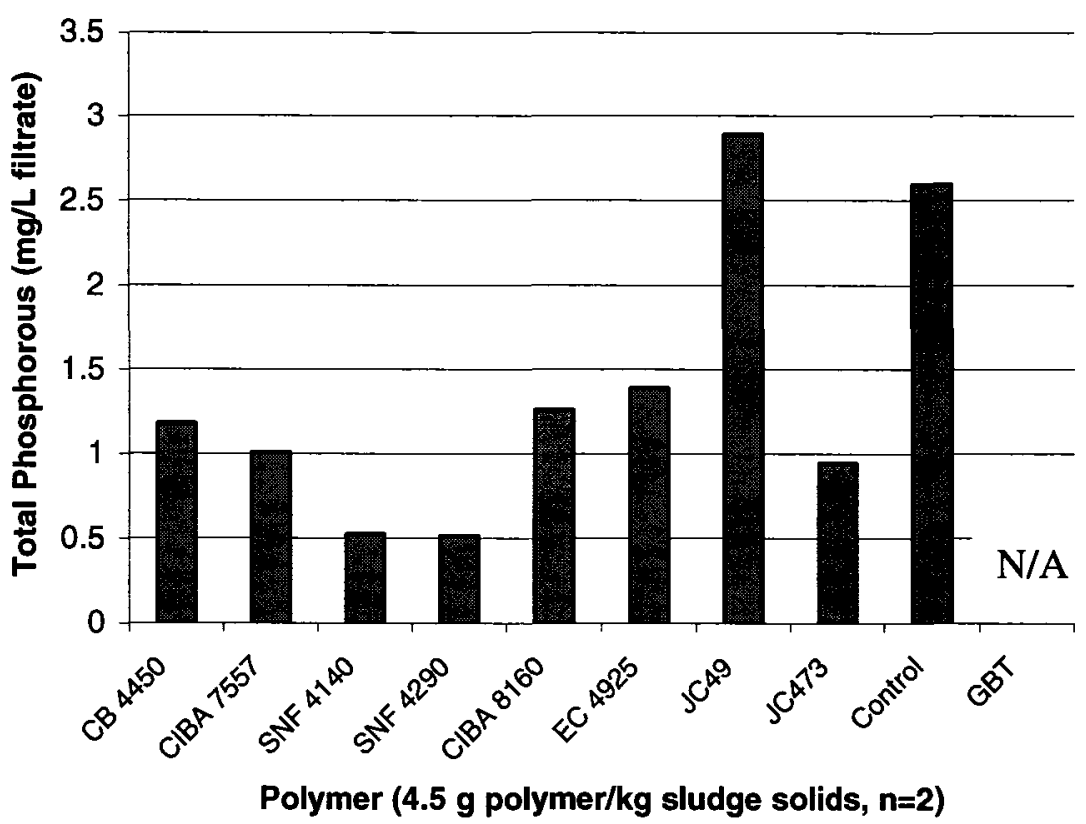

Figure 4.10 - Total Phosphorous Concentration of Filtrate

The concentration of total phosphorous in filtrate is shown in Figure 4.10. This is a particularly important parameter, because chemical coagulants are used to remove phosphorous from wastewater at Crystal Beach WWTP. Thus, using a polymer that reduces the amount of total phosphorous in the recycled filtrate may improve plant effluent and save money. The data suggests that, with the exception of polymer JC49, all polymers reduce the amount of total phosphorous in the filtrate compared to control samples, which averaged about $2.5 \mathrm{mg}$ total phosphorous per liter filtrate. Polymers CB 4450, CIBA 8160 and EC 4925 lower the total phosphorous concentration in filtrate to between 1 and $1.5 \mathrm{mg}$ total phosphorous per liter (about half the concentration of the control sample). Polymer CIBA 7557 produced filtrate with a total phosphorous concentration of approximately $1.0 \mathrm{mg} / \mathrm{L}$. With respect to total phosphorous removal, the SNF polymers appear to do the best job, producing filtrate with approximately $0.5 \mathrm{mg}$ 
total phosphorous per liter, reducing total phosphorous by about 80 percent relative to the control sample.

\subsubsection{Bench Scale Testing - Nutrient Values Adjusted}

In this section, the concentration of total phosphorous and TKN in solid phase is examined in concert with the percent total solids data, by using the total solids percentage to normalize the nutrient data. In other words, the nutrient concentrations observed in this section are not expressed in mg per $\mathrm{kg}$ thickened sludge, they are listed in $\mathrm{mg}$ per $\mathrm{kg}$ dry solids. The nutrient concentration data are divided by the total solids percentage in this analysis, (see Appendix 2 for sample calculation). This analysis ties the nutrient concentration of the sludge to the total solids content, thereby correcting for differences in the liquid content of the sludge. In section 4.1.2, the nutrient concentration of thickened sludge is measured by sampling the thickened sludge as it is thickened by the gravity filter. This means that the sludge samples may have very different percentages of solid material. For example, sludge thickened using polymer CIBA 8160 averaged over 5 percent total solids, while sludge thickened using polymer JC 49 averaged under one percent total solids. Since the sludge solids are a potent source of nutrient chemicals, sludge with a higher solids percentage also has a higher concentration of nutrient chemicals. By dividing the nutrient chemical concentrations by the percent total solids, it is possible to characterize the chemistry of the sludge without allowing differences in solids content affect the results. In Figure 4.11, the total phosphorus concentration of the thickened sludge is examined, while in Figure 4.12, the TKN concentration of the sludge is displayed 


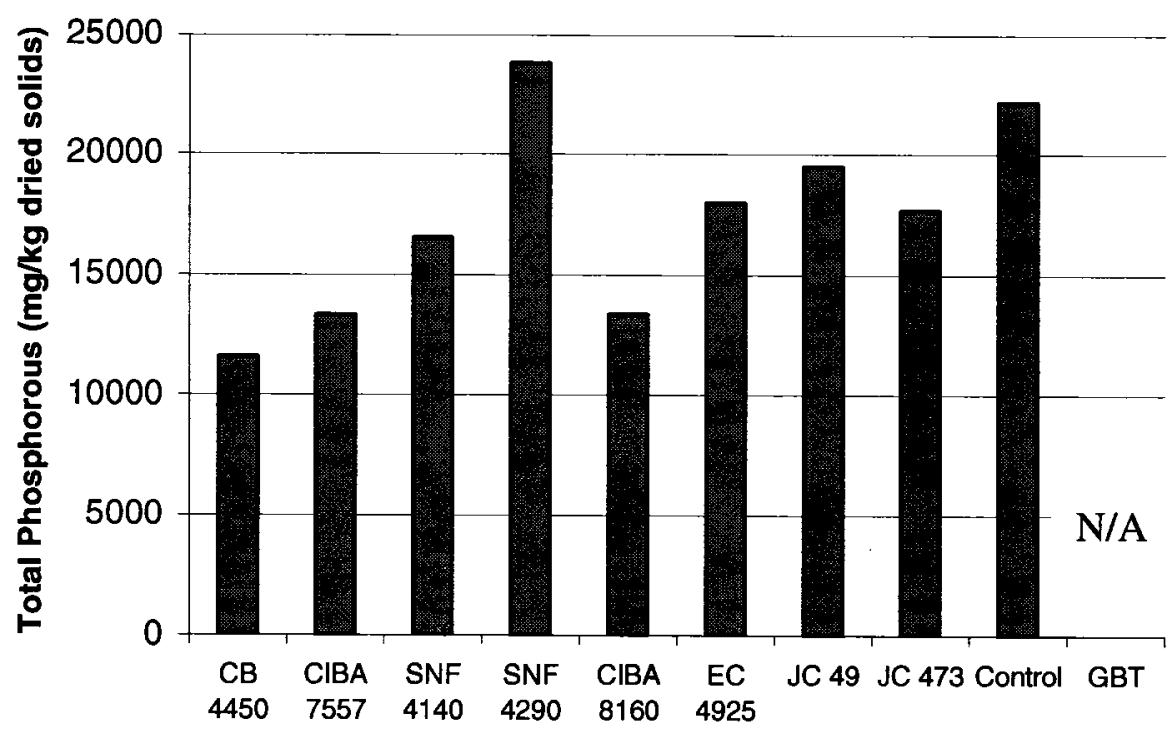

Polymer (4.5 mg dry polymer/kg sludge solids, $n=2$ )

Figure 4.11 - Total Phosphorous Concentration of Thickened Sludge Normalized Using Total Solids

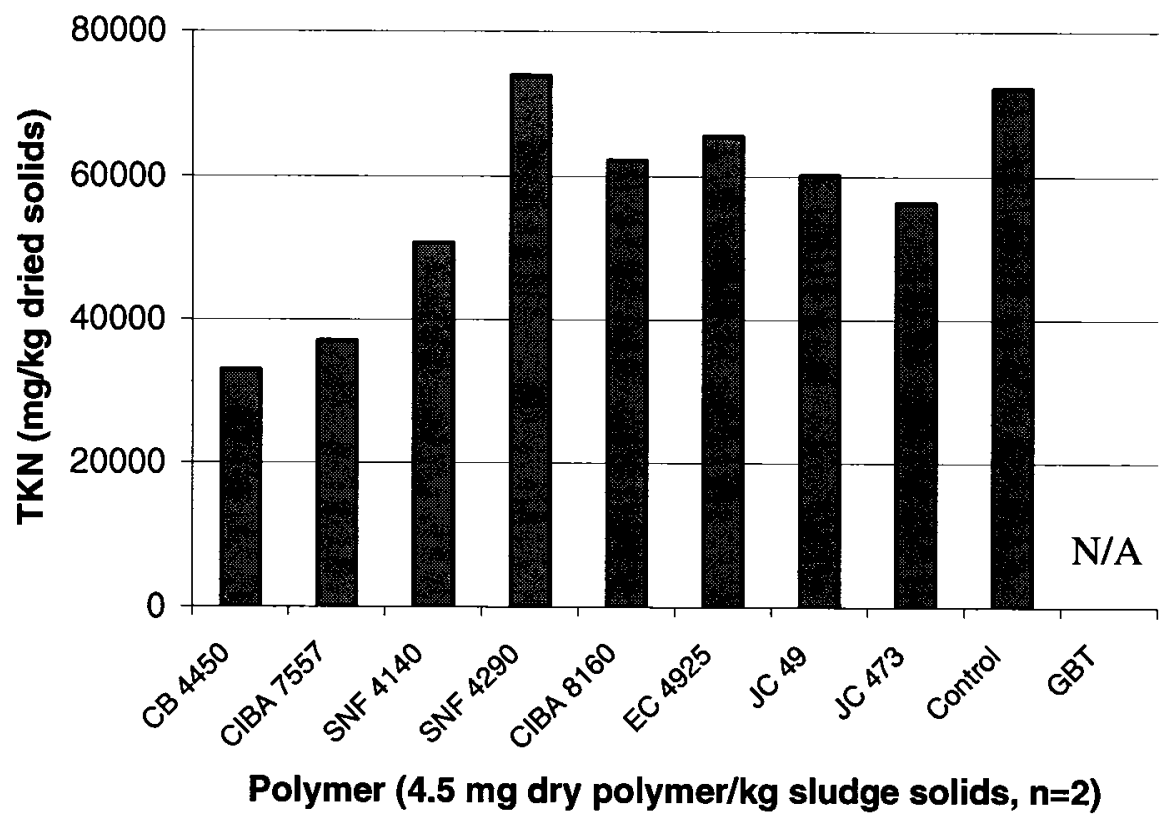

Figure 4.12 - TKN Concentration of Thickened Sludge Normalized Using Total Solids

This analysis shows that there may indeed be chemical differences in the sludge produced by the different polymers. For example, with the exception of polymer SNF 4290, all 
polymers produce sludge with lower concentrations of total phosphorous and TKN per unit weight of dried solids than the control sample, which was not dosed with polymer. In fact, the incumbent polymer produced sludge with the lowest levels of total phosphorous and TKN per kilogram dried solids on average. This suggests that the polymers may dilute the nutrient concentration of the sludge to varying degrees. Perhaps polymers cause chemical reactions that alter nutrient chemicals, making them unavailable for other chemical reactions. Polymers may cause damage to organisms in the sludge, causing cell lysis and/or breakdown of organics. In the future, a more in depth look at the interactions between polymers and nutrient chemicals in sludge during thickening may shed some light on the effects of polymer conditioning on the availability of nutrients in thickened sludge. A similar analysis was not performed using the filtrate data, due to the high variability in the solids content of filtrate samples (see Figure 4.7).

\subsubsection{Summary of Bench-Scale Polymer Screening}

The data from bench-scale polymer testing are presented in Table 4.1 (thickened sludge data) and Table 4.2 (filtrate data), along with the rank of each polymer in each test. In the case of the thickened, a rank of 1 indicates the polymer that was most effective at producing sludge with the highest total solids percentage or highest nutrient concentration. In the case of the filtrate, the opposite is true; a rank of 1 indicates the polymer that was most effective at producing filtrate with the lowest solids percentage and nutrient concentration. For subsequent testing, polymers SNF 4290 and EC 4925 were chosen. Polymer SNF 4290 had the lowest average rank for both thickened sludge and filtrate testing, (average rank of 3). Polymers CIBA 7557, CIBA 8160, and EC 4925 
had the next average rank, (average rank of 4.25). Polymer EC 4925 seemed to be most consistent of these three, exhibiting lower variability, and producing thickened sludge with relatively high levels of total solids, TKN and total phosphorous. Both polymers selected for subsequent testing were relatively effective at producing thickened sludge with consistent solids content, and were most effective at producing thickened sludge with high nutrient content relative to other polymer types. From a practical perspective, the nutrient content of the sludge was a secondary objective compared to the solids percentage, because the thickened sludge must have solid content within the design specifications of the full-scale thickening apparatus, between 4 and 6 percent total solids. Overall, the filtrate data appeared to be less important for selection. The filtrate samples had highly variable values for nutrient concentrations, probably because it was difficult to produce filtrate with consistent total solids content. An alternative and automatic way of analysing the bench-scale data was also explored. To rank polymer performance, the data for a given parameter was averaged across all the polymers, and the datasets could then be converted to $\mathrm{z}$-scores. This allowed for different parameters to be weighted when calculating the average rank of a given polymer. To see the analysis, see Appendix 6.

Table 4.1 - Summary of Data from Bench-Scale Polymer Testing - Solid Phase

\begin{tabular}{|c|c|c|c|c|c|c|c|c|c|}
\hline \multirow[t]{2}{*}{ Polymer } & \multicolumn{2}{|c|}{$\begin{array}{l}\text { Total } \\
\text { Solids }\end{array}$} & \multicolumn{2}{|c|}{$\begin{array}{c}\text { Total } \\
\text { Phosphorous }\end{array}$} & \multicolumn{2}{|c|}{ TKN } & \multicolumn{2}{|c|}{ tBOD } & \multirow[t]{2}{*}{$\begin{array}{c}\text { Average } \\
\text { Rank }\end{array}$} \\
\hline & $\%$ & Rank & $\mathrm{mg} / \mathbf{k g}$ & Rank & $\mathrm{mg} / \mathrm{kg}$ & Rank & $\mathrm{mg} / \mathrm{kg}$ & Rank & \\
\hline CB 4450 & 4.5 & 5 & 519 & 6 & 1480 & 6 & 13380 & 4 & 5.25 \\
\hline CIBA 7557 & 4.9 & 3 & 651 & 4 & 1830 & 4 & 22030 & 2 & 3.25 \\
\hline SNF 4140 & 3.4 & 6 & 550 & 5 & 1685 & 5 & 13960 & 3 & 4.75 \\
\hline SNF 4290 & 4.6 & 4 & 1085 & 1 & 3370 & 1 & 22950 & 1 & 1.75 \\
\hline CIBA 8160 & 5.2 & 1 & 687 & 3 & 3220 & 3 & 11540 & 5 & 3.00 \\
\hline EC 4925 & 5.1 & 2 & 913 & 2 & 3320 & 2 & 11390 & 6 & 3.00 \\
\hline JC 49 & 0.8 & 9 & 166 & 9 & 513 & 9 & 10130 & 7 & 8.50 \\
\hline JC 473 & 2.1 & 7 & 265 & 7 & 844 & 7 & 9500 & 8 & 7.25 \\
\hline Control & 1.3 & 8 & 250 & 8 & 744 & 8 & N/A & N/A & 8.00 \\
\hline
\end{tabular}


Table 4.2 - Summary of Data from Bench-Scale Polymer Testing - Liquid Phase

\begin{tabular}{|l|c|c|c|c|c|c|c|c|c|}
\hline \multirow{2}{*}{ Polymer } & \multicolumn{2}{|c|}{ Total Solids } & \multicolumn{2}{c|}{$\begin{array}{c}\text { Ammonia } \\
\text { Nitrogen }\end{array}$} & \multicolumn{2}{c|}{ TKN } & \multicolumn{2}{c|}{$\begin{array}{c}\text { Total } \\
\text { Phosphorous }\end{array}$} & $\begin{array}{c}\text { Average } \\
\text { Rank }\end{array}$ \\
\cline { 2 - 9 } & $\%$ & Rank & $\mathbf{m g / L}$ & Rank & $\mathbf{m g} / \mathbf{L}$ & Rank & $\mathbf{m g} / \mathbf{L}$ & Rank & \\
\hline CB 4450 & .036 & 4 & .96 & 9 & 5.6 & 7 & 1.18 & 5 & 6.25 \\
\hline CIBA 7557 & .033 & 2 & .68 & 8 & 5.2 & 6 & 1.01 & 4 & 5.00 \\
\hline SNF 4140 & .065 & 9 & .34 & 4 & 2.7 & 1 & 0.53 & 2 & 4.00 \\
\hline SNF 4290 & .055 & 8 & .40 & 6 & 2.9 & 2 & 0.52 & 1 & 4.25 \\
\hline CIBA 8160 & .039 & 5 & .61 & 7 & 3.5 & 3 & 1.31 & 6 & 5.25 \\
\hline EC 4925 & .044 & 6 & .38 & 5 & 3.5 & 3 & 1.45 & 7 & 5.25 \\
\hline JC 49 & .035 & 3 & .16 & 2 & 9.1 & 9 & 2.89 & 9 & 5.75 \\
\hline JC 473 & .032 & 1 & .15 & 1 & 3.9 & 5 & 0.95 & 3 & 2.50 \\
\hline Control & .052 & 7 & .29 & 3 & 7.9 & 8 & 2.59 & 8 & 6.50 \\
\hline
\end{tabular}

\subsubsection{Polymer Testing - Screen Test (Phase 3)}

The purpose of the Phase 3 testing plan was to determine appropriate dosages for the polymers for subsequent full-scale testing. In Figure 4.13, the curve shows the percent solids of thickened sludge after conditioning with three different polymer types. Polymer CB 4450, represented by the diamond-shaped data points, is the incumbent polymer at Crystal Beach WWTP. Each polymer type is tested at five different dosages. The data shows that over the dosage range used, the polymers are always within one percentage point of one another. It is also apparent that increasing the dosage past a certain point only causes a marginal increase in solids percentage, and that increasing further may actually cause thickened sludge with lower total solids. It is expected that an overdose of polymer may increase the moisture content of thickened sludge, as excess polymer may produce large, loosely bound flocs with water incorporated into the floc structure (Vaxelaire and Olivier, 2006; Mikkelsen and Keiding, 2001). Therefore, it seems that to achieve a thickened sludge total solids percentage of about five percent requires a dosage 
of about $3.75 \mathrm{~g}$ dry polymer per kilogram sludge solids. Increasing the dose will be only marginally effective, and may actually lower the solids content of the sludge.

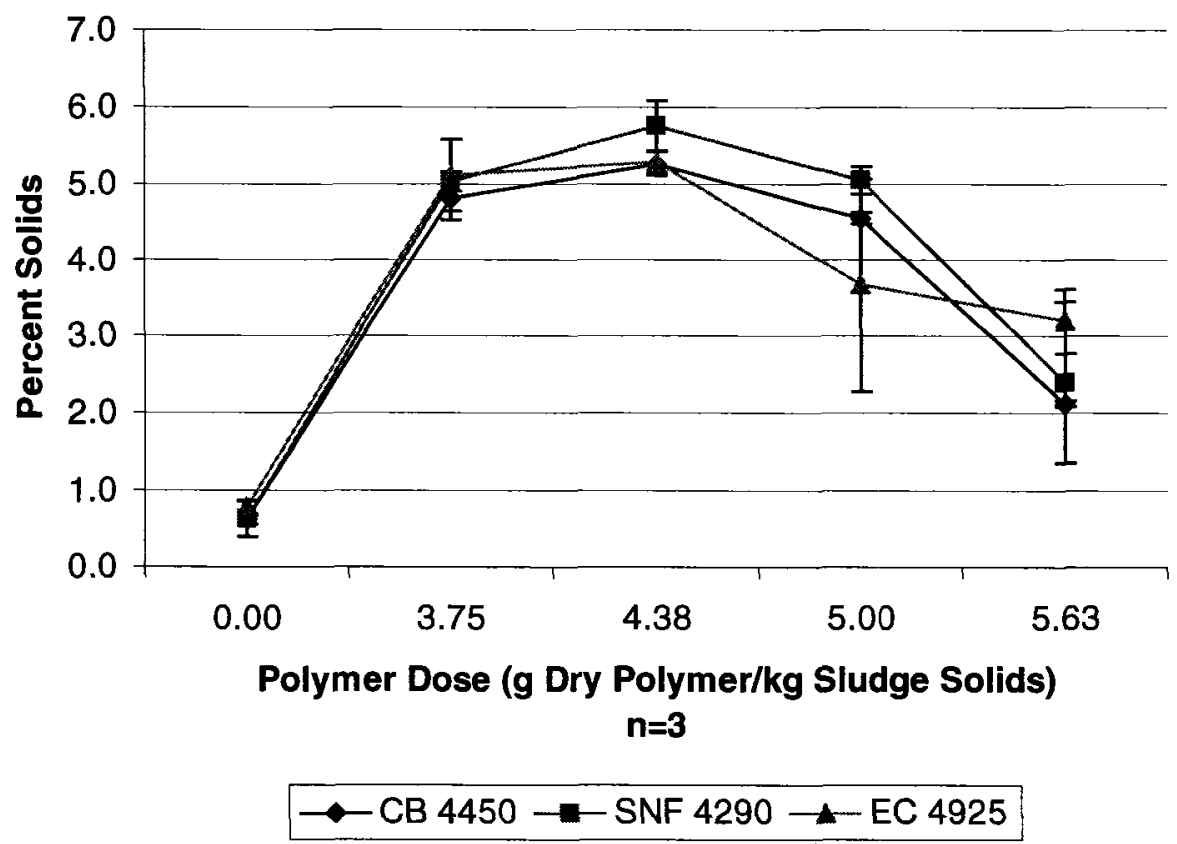

Figure 4.13 - Thickened Sludge Percent Solids \pm 1 Standard Deviation Dosage Curve

Figure 4.14 shows the liquid phase solids percentage on the left vertical axis, and tBOD concentration on the right vertical axis. This shows that the dose of polymer may affect the filtrate solids concentration differently than it affects the oxygen demand of the filtrate. Achieving a total solids percentage of approximately 0.05 percent is possible with the lowest polymer dose, (3.75 g dry polymer per kg sludge solids), and higher doses do not appear to result in significantly lower percent total solids. However, maximum reductions in $\mathrm{tBOD}$ concentration occur only at a much higher dose, $(5.00 \mathrm{~g}$ dry polymer per $\mathrm{kg}$ sludge solids). This data suggests that achieving simultaneous advantages in $\mathrm{tBOD}$ and solids removal from GBT filtrate may be impractical, since the dose required to maximize solids removal is much lower than the dose required to 
maximize tBOD removal. In this case, it is helpful to consider tBOD to be akin to the nutrient chemicals examined, such as phosphorous and nitrogen. While this is not technically true, it is common to consider BOD a pseudo-nutrient, as it is an indicator of the potency of wastewater, and is a measure of a type of load (i.e. a demand for oxygen), that can affect aquatic environments (Droste, 1997). The importance of this tBOD analysis is that we are able to see the difference between how a polymer affects solids capture versus the chemistry of the filtrate. Using polymer dosing to minimize the tBOD of GBT filtrate requires 75 percent higher polymer dose than that required to minimize filtrate percent solids.

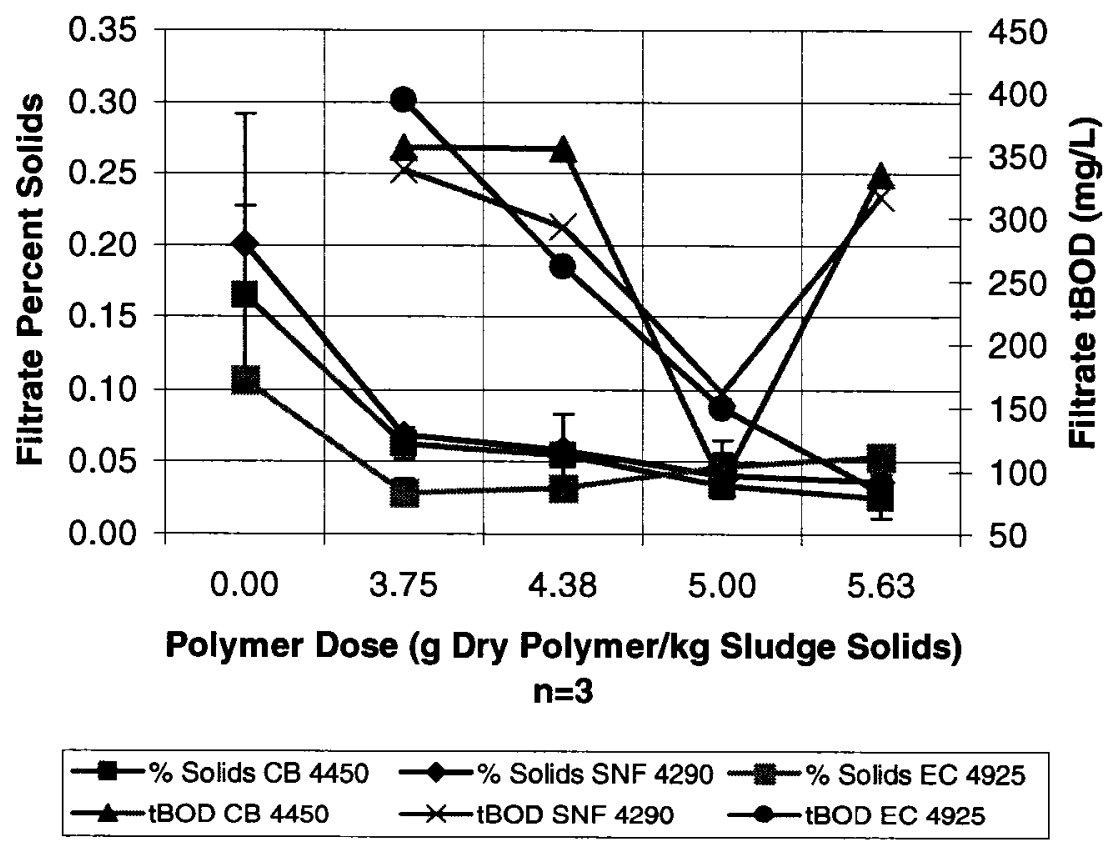

Figure 4.14 - Percent Solids \pm 1 Standard Deviation and Total BOD of Filtrate 
In Figure 4.15 , the filtrate is characterized by turbidity over a range of polymer doses. The dosage range is slightly different than that used in figure 4.14. This was necessary because at low polymer doses, the filtrate is too turbid for accurate measurement, and so higher polymer doses were used for this test. The data suggests that SNF 4290 and EC 4925 may be more effective at lowering filtrate turbidity than polymer CB 4450 at doses below 3.75 grams dry polymer per kilogram sludge solids. Therefore, the two trial polymers were tested at full-scale at a minimum dose of $1.85 \mathrm{~g}$ dry polymer/kilogram sludge solids, while the minimum dose that the incumbent CB 4450 polymer was tested at was $2.75 \mathrm{~g}$ dry polymer/kg sludge solids. See figures 4.19 and 4.20 for a comparison to full-scale filtrate suspended solids content and turbidity.

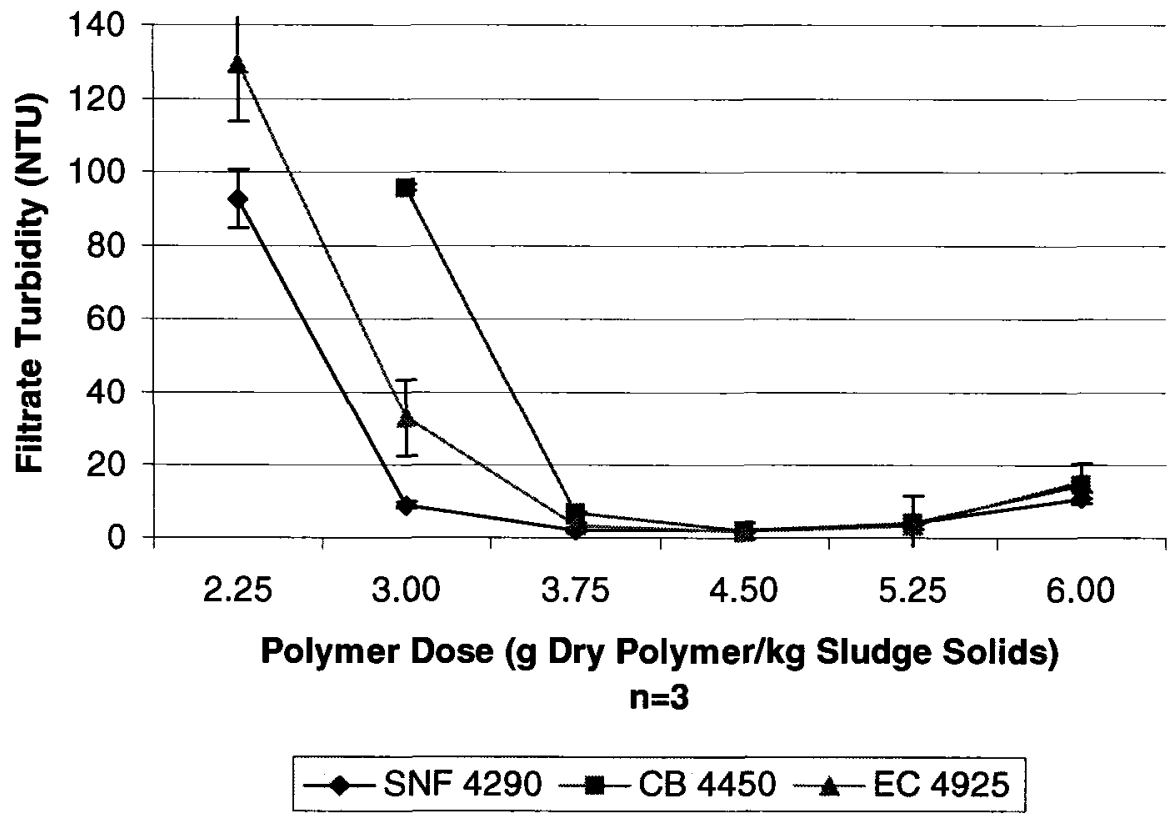

Figure 4.15 - Filtrate Turbidity \pm 1 Standard Deviation Dosage Curve 


\subsubsection{Polymer Testing - Full Scale Trials (Phase 4)}

In the following sections, the results of full-scale sampling and analysis are discussed. During full-scale sampling, one of the three polymer types were tested for two weeks. For each week, samples were collected in triplicate over a range of six dosages. The following week, the same dosages were applied, in order to ensure that the data obtained in the first week was reproducible on the second week. To test whether the data was indeed similar on both weeks, a Student's t-test of paired comparison was performed to ensure that the data sets for each dose came from the same population of data. Although the majority of data sets were within a 95 percent confidence interval, some were outside the 95 percent interval. To see the results of the statistical analysis of the paired fullscale data, see Appendix 5.

The dosage range was implemented by adjusting the polymer distribution system pump to deliver a set amount of polymer solution to the WAS before reaching the GBT. Although bench scale testing occurred at only one dose, it was possible to compare bench scale testing with some of the full scale results. However, since the loading rates of the bench apparatus in phase 2 testing was different from the full scale loading rate and timing on the full scale apparatus, a direct comparison of bench scale versus full scale results was not one of the major investigations pursued in this research. Bench scale testing was designed to predict the relative performance of different polymers at full scale. See Appendix 7 for a direct comparison of bench scale and full scale results. Thickened sludge samples were taken from the GBT belt just prior to the outlet, while filtrate was sampled from the filtrate collection pipes before entering the filtrate drain beneath the 
GBT. The data obtained from analysing the thickened sludge and filtrate samples is presented graphically in Sections 4.17 and 4.18.

\subsubsection{Data From Full-Scale Sampling}

Figure 4.16 shows total solids percentage of thickened sludge samples. All three polymers produce sludge between 4 and 5 percent total solids at a dosage of $3.65 \mathrm{~g}$ dry polymer per kg sludge solids. At a lower dose of $2.75 \mathrm{~g}$ dry polymer per $\mathrm{kg}$ sludge solids, the two trial polymers deliver sludge over 4 percent total solids, while the incumbent delivers sludge under 2 percent total solids. This data suggests that achieving sludge total solids percentage of over 4 percent can be done at a lower dose with either trial polymer relative to the incumbent polymer. At doses above $3.65 \mathrm{~g}$ dry polymer per kilogram sludge solids, increases in percent total solids were small, and all three polymers produced thickened sludge between approximately 5 and 6 percent. This suggests that with respect to solids capture, either trial polymer may produce a savings in polymer demand of about 25 percent, as long as proper dose control is maintained, and assuming that thickened sludge with a total solids percentage of 4 percent is acceptable.

There is some discrepancy between the bench-scale data observed in Figure 4.13 and the full-scale data observed in Figure 4.16. The bench-scale dosage data suggested that increasing polymer dose above $4.55 \mathrm{~g}$ dry polymer per kilogram digested sludge will negatively impact sludge total solids. At bench-scale, a dose of $5.63 \mathrm{~g}$ dry polymer per kilogram sludge solids produced thickened sludge below 4 percent solids, for all 
polymers tested. On the other hand, the full-scale data shows that dosages up to $7.25 \mathrm{~g}$ dry polymer per kilogram sludge solids produced sludge between approximately 5 and 6 percent solids. This highlights an important difference between the bench-scale model and the full-scale application. There seems to be a need for developing dedicated models that can be used to mimic full-scale plant behaviour at bench or pilot scale. Perhaps conditioning occurs more efficiently at higher polymer doses in the full-scale apparatus than in the bench-scale simulation. In the future, studies dedicated to characterizing these differences would be useful, and would allow for a more deliberate bench-scale investigation of polymer performance.

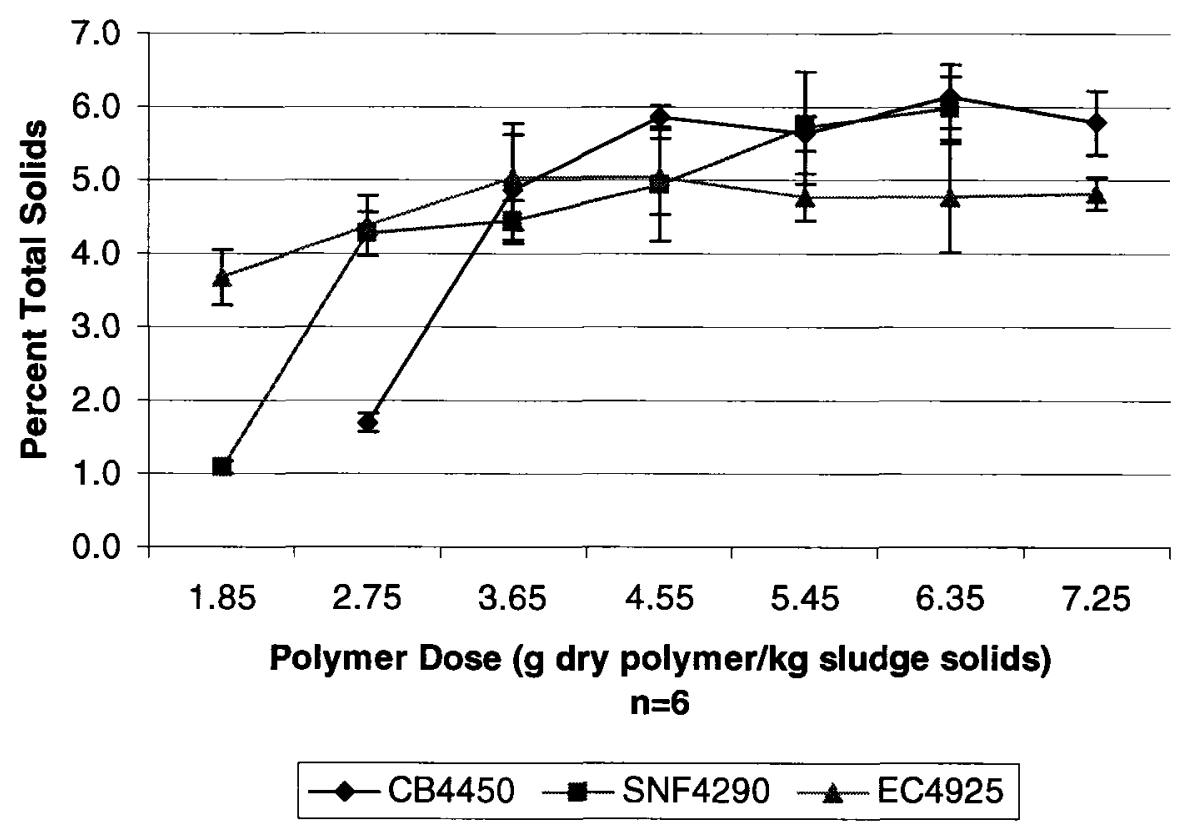

Figure 4.16 - Full-scale Percent Total Solids of Thickened Sludge \pm 1 Standard Deviation

Figure 4.17 and Figure 4.18 examine the TKN and total phosphorous content of thickened sludge. The data shows that at low doses, $(1.85$ to $2.75 \mathrm{~g}$ dry polymer per $\mathrm{kg}$ 
sludge solids), polymer SNF 4290 produces thickened sludge with a higher concentration of nutrient chemicals, increasing both the TKN and total phosphorous concentration of thickened sludge by approximately two and a half times. At a dosage of $3.65 \mathrm{~g}$ dry polymer per kg sludge solids, the two polymers perform within one standard deviation of one another. At dosages between 4.55 and $5.65 \mathrm{~g}$ dry polymer per $\mathrm{kg}$ sludge solids, however, the incumbent polymer CB 4450 produces sludge with relatively higher TKN and total phosphorous concentration in thickened sludge, increasing both parameters by approximately 50 percent relative to polymer SNF 4290 .

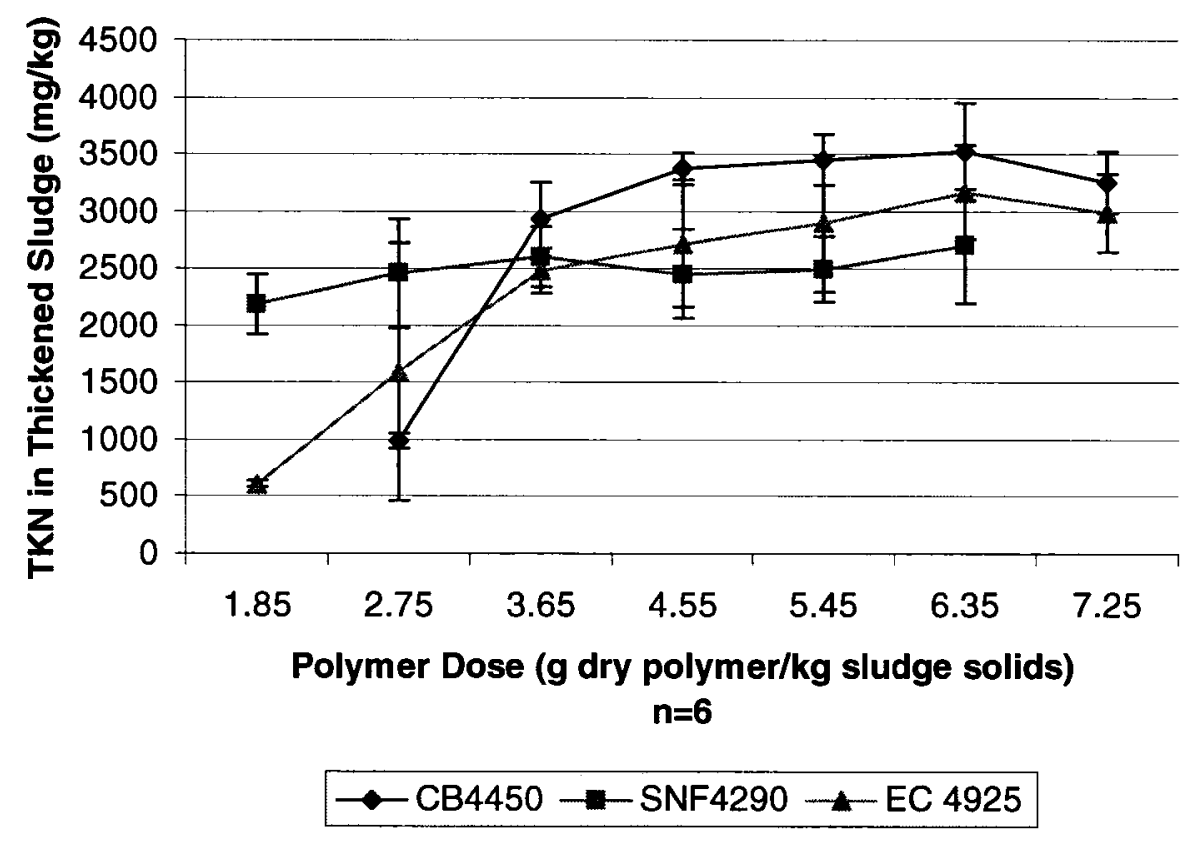

Figure 4.17 - Full-scale Thickened Sludge TKN Concentration \pm 1 Standard Deviation 


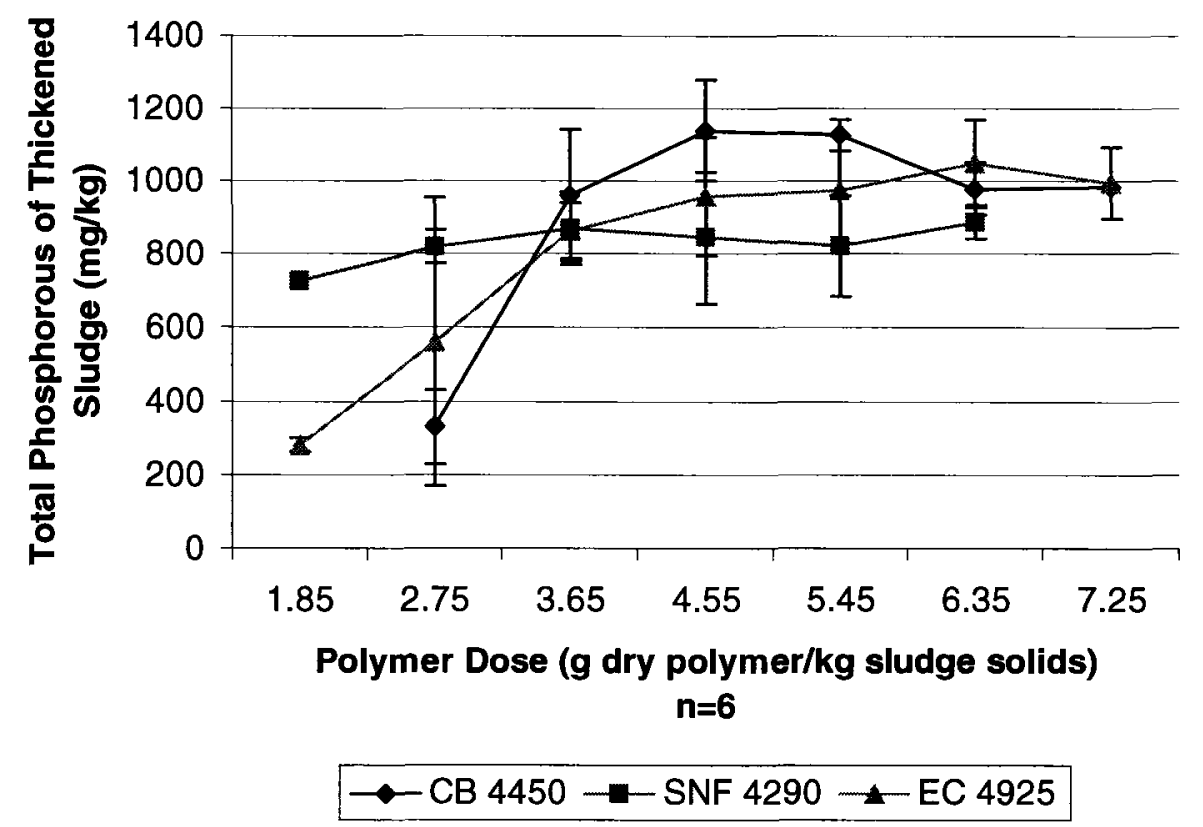

Figure 4.18 - Full-scale Thickened Sludge Total Phosphorous Concentration \pm 1 Standard Deviation

In Figure 4.19, the suspended solids concentration of the filtrate is shown. In this test, the two trial polymers are shown to produce filtrate with a suspended solids concentration below $300 \mathrm{mg} / \mathrm{L}$ at all at polymer dosages above $2.75 \mathrm{~g}$ dry polymer per kg sludge solids. The incumbent polymer produces filtrate with approximately ten times the suspended solids concentration at the $2.75 \mathrm{~g}$ dry polymer per kg sludge solids dosage. At dosages of $3.65 \mathrm{~g}$ dry polymer per $\mathrm{kg}$ sludge solids and above, the three polymers appear to perform approximately equally. 


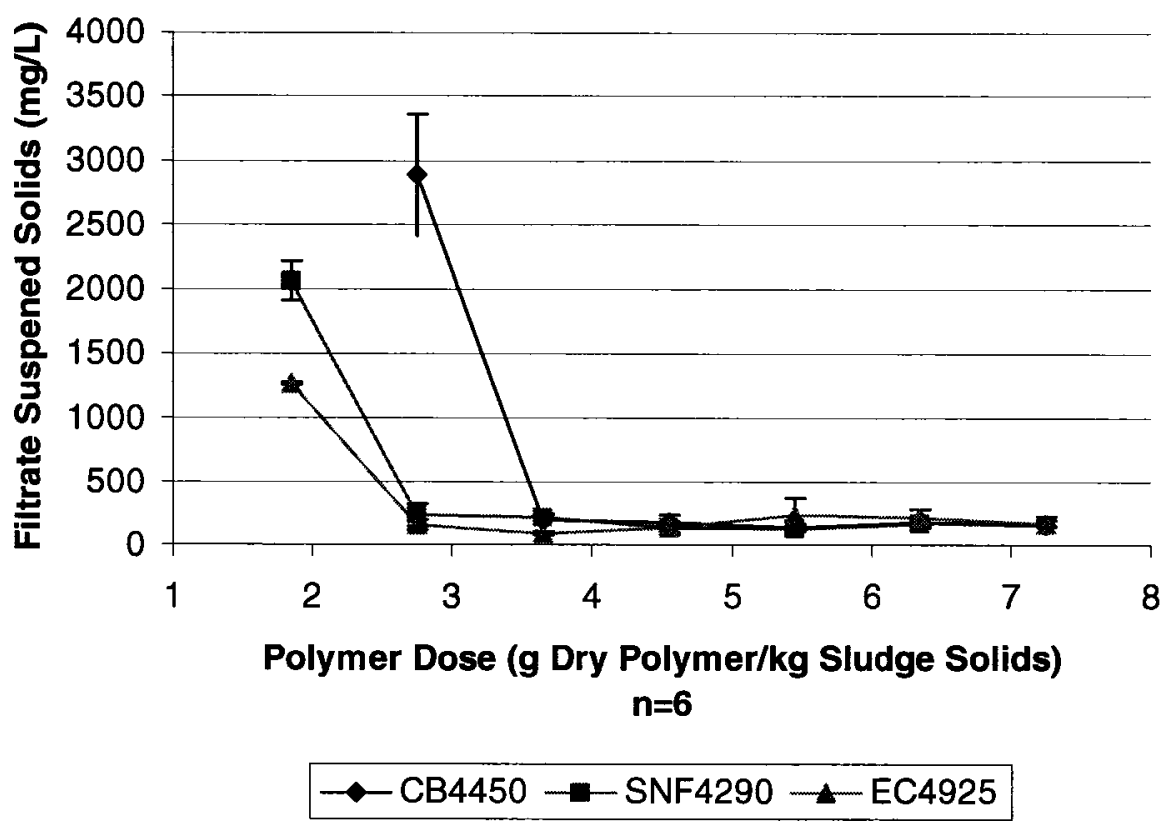

Figure 4.19 - Full-scale Suspended Solids Concentration in Filtrate \pm 1 Standard Deviation

In Figure 4.20, the data shows that trial polymers produce filtrate with turbidity below $200 \mathrm{NTU}$ at all dosages from $2.75 \mathrm{~g}$ dry polymer per kg sludge solids. At a dose of 2.75 g dry polymer per kilogram sludge solids, the trial polymers produce filtrate with 80 percent lower turbidity than the incumbent. The incumbent polymer must be applied at a dosage of at least $3.65 \mathrm{~g}$ dry polymer per $\mathrm{kg}$ sludge solids to achieve filtrate turbidity below 200 NTU. 


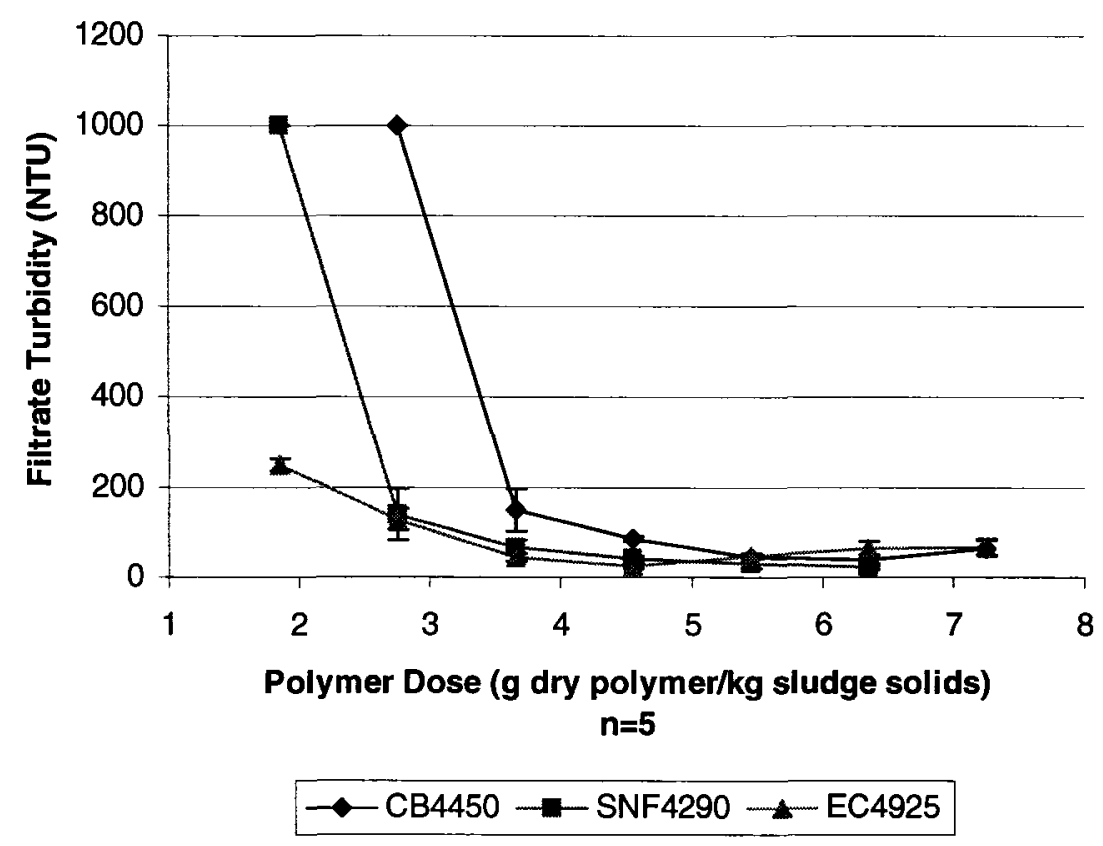

Figure 4.20 - Full-scale Filtrate Turbidity \pm 1 Standard Deviation

The total phosphorous concentration observed in filtrate is shown in Figure 4.21. This data is less conclusive than the data pertaining to the solid phase analysis in Figures 4.16, 4.17 and 4.18. Due to the variability observed, it seems that dosages of $3.65 \mathrm{~g}$ dry polymer per $\mathrm{kg}$ sludge solids or more are needed to ensure total phosphorous concentration in filtrate of $5 \mathrm{mg} / \mathrm{L}$. At the dose of $2.75 \mathrm{~g}$ dry polymer per kilogram sludge solids, the incumbent polymer produces filtrate with mean total phosphorous concentration 75 percent higher than polymer SNF 4290, and 300 percent higher than EC 4925, although the data from CB 4450 and SNF 4290 are within one standard deviation of one another. At higher doses, however, all polymers perform similarly. Thus, at fullscale, it seems unlikely that an overall reduction in total phosphorous in filtrate is possible with any of the polymers tested, even though an overall polymer savings may be observed when either trial polymer is used. This data shows that switching polymers to 
achieve a polymer savings may be a wise decision, since the trial polymers achieve about the same total phosphorous concentration as the incumbent polymer at the lower dose of $2.75 \mathrm{~g}$ dry polymer per kilogram sludge solids. In other words, the thickening process at Crystal Beach WWTP could be operated using the trial polymers, and a similar solids capture could be achieved compared to when the incumbent polymer is in use, but at a lower polymer dose ( $2.75 \mathrm{~g}$ dry polymer per $\mathrm{kg}$ sludge solids versus $3.65 \mathrm{~g}$ dry polymer per kg sludge solids). The data show that using the trial polymers at the lower dose is unlikely to impact the phosphorous loading of the WWTP due to the GBT filtrate stream, because the concentration of total phosphorous in the filtrate is comparable in either scenario. The implications of using the trial polymers at the lower dose of $2.75 \mathrm{~g}$ dry polymer per kilogram sludge solids versus the incumbent at a dose of $3.65 \mathrm{~g}$ dry polymer per kilogram sludge solids are explored in Section 4.4.2.

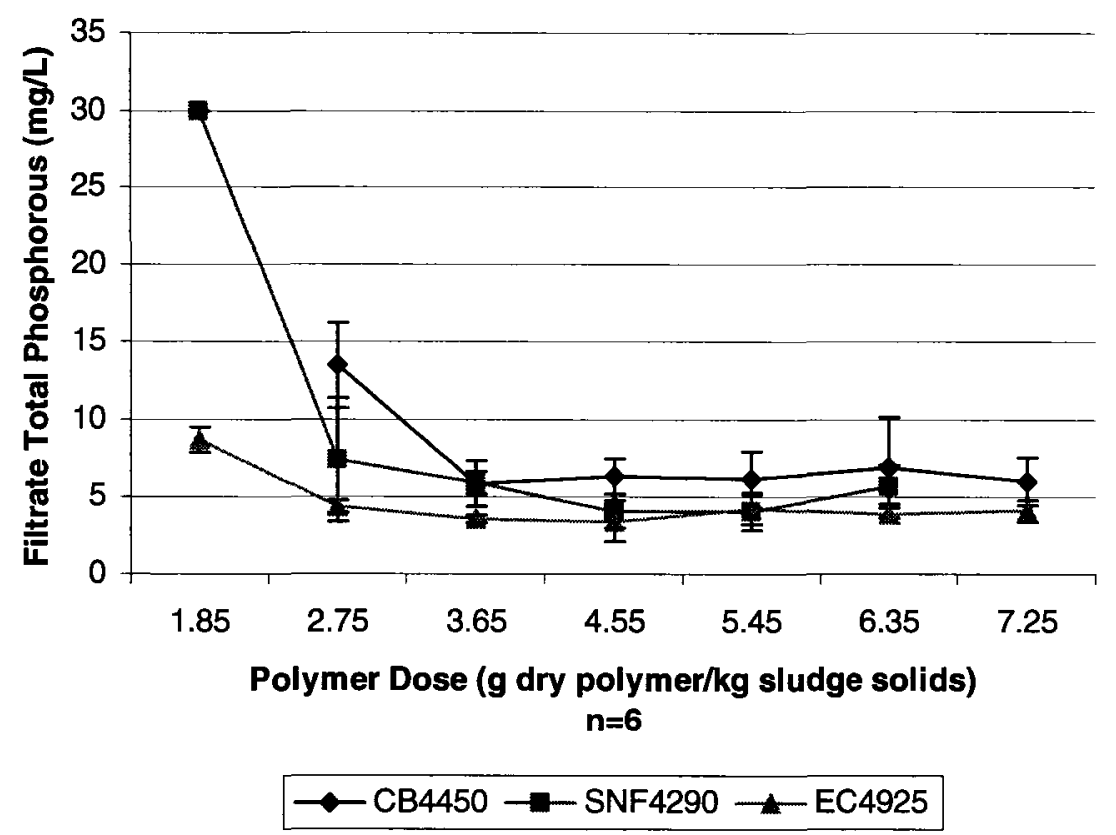

Figure 4.21 - Full-scale Total Phosphorous Concentration in Filtrate \pm 1 Standard Deviation 
Figure 4.22 shows the ammonia concentration observed in filtrate. The data shows that at dosages of $2.75 \mathrm{~g}$ dry polymer per $\mathrm{kg}$ sludge solids and up, the trial polymers produce filtrate with an ammonia concentration near $0.5 \mathrm{mg}$ ammonia per liter filtrate, while the incumbent produces filtrate with an ammonia concentration about 4 times higher at the $2.75 \mathrm{~g}$ dry polymer per kilogram sludge solids dosage. The incumbent polymer achieves filtrate concentration around $5 \mathrm{mg} / \mathrm{L}$ only at the two highest dosages, above $6.35 \mathrm{~g}$ dry polymer per kilogram sludge solids.

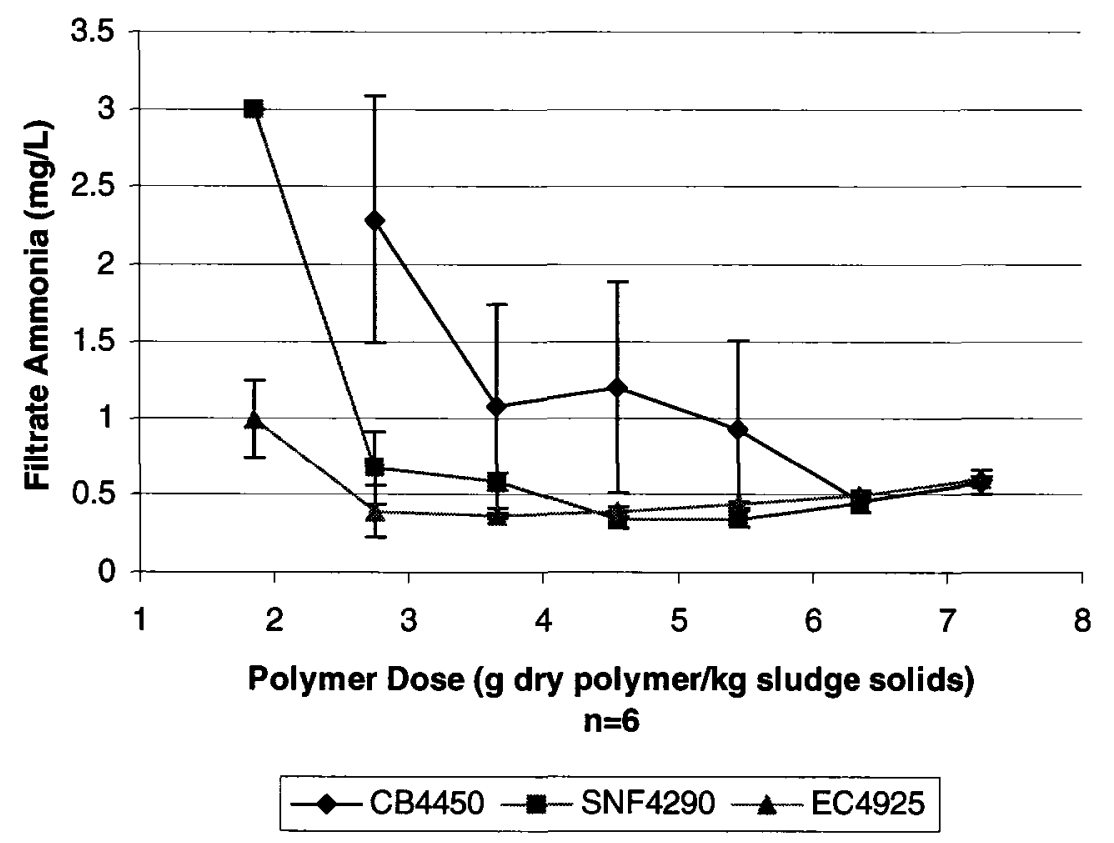

Figure 4.22 - Full-scale Ammonia Concentration in Filtrate \pm 1 Standard Deviation 


\subsubsection{Examination of Trial Polymers at Lower Doses}

The data presented in Section 4.4.1 suggests that achieving a total solids level of thickened sludge between 4 and 5 percent may be achieved at a 25 percent lower polymer dose using one of the trial polymers instead of the incumbent polymers. However, the purpose of this study has been to look at both the solids capture and the nutrient loading of solid and liquid streams during thickening. Therefore, in order to justify using a trial polymer in place of the incumbent, it is necessary to examine how the trial polymers will affect nutrient direction at the lower dose. The doses examined are $2.75 \mathrm{~g}$ dry polymer per kilogram sludge solids and $3.65 \mathrm{~g}$ dry polymer per kilogram sludge solids. Figure 4.23 shows that the trial polymers achieve a solids capture at either dose between 4 and 5 percent total solids, which is approximately equal to the incumbent polymer, but only when the incumbent is applied at the higher dose. In Figure 4.24, the full-scale TKN content of thickened sludge is shown, while in Figure 4.25 , the corresponding total phosphorous data is shown. In both cases, at the lower dose, polymer SNF 4290 clearly outperforms the incumbent polymer. Furthermore, at the lower dose, SNF 4290 produces sludge within about 10 percent of the TKN and total phosphorous content of the incumbent polymer at the higher dose. Polymer EC 4925, on the other hand, produces thickened sludge only about half as concentrated in TKN and total phosphorous at the lower dose compared to the incumbent at the higher dose. In Figure 4.26, the total phosphorous content of filtrate is shown. Polymer SNF 4290 produces filtrate averaging about 25 percent higher in total phosphorous using the lower dose than the incumbent polymer dose at the higher dose, although there is a fair degree of variability in this data. Overall, the data shown here allow for a more deliberate decision making process. It is 
clear that switching polymers from the incumbent to polymer SNF 4290 at the lower dosage results in similar solids and nutrient capture for this thickening application. However, the data show that a maximum decrease in TKN and total phosphorous content of thickened sludge of about 10 percent, and a maximum increase in filtrate total phosphorous of approximately 25 percent may be expected. If any costs associated with these nutrient concentration changes are less than the savings associated with a 25 percent savings in polymer, then switching polymer may be recommended.

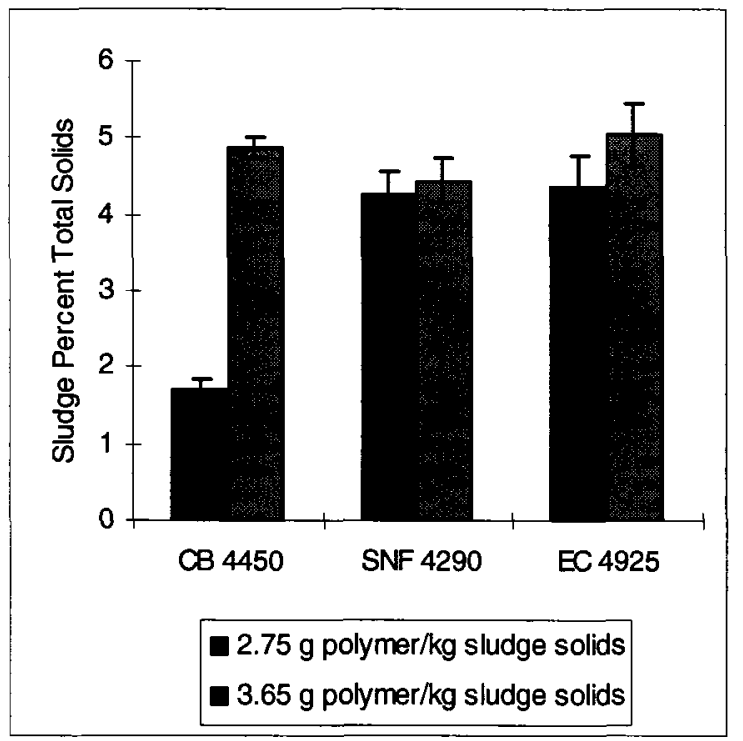

Figure 4.23 - Full-Scale Sludge Total Solids; $n=6$

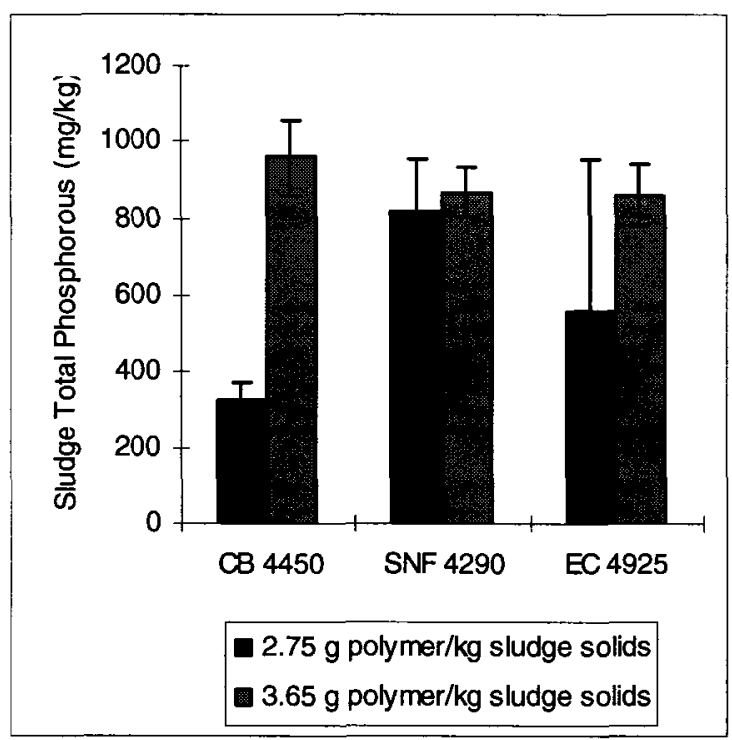

Figure 4.25 - Full-Scale Sludge Total Phosphorous; $n=6$

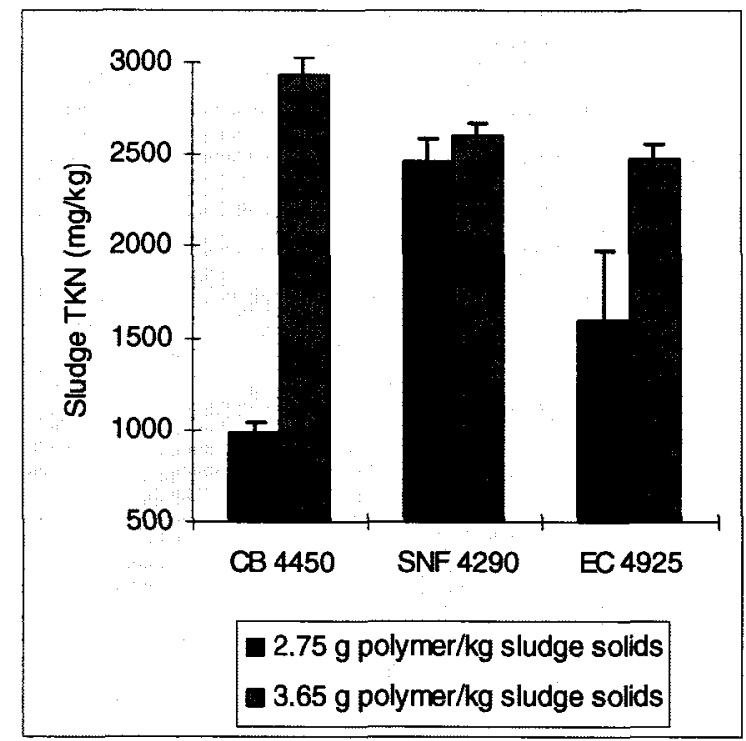

Figure 4.24 - Full-Scale Sludge TKN; n=6

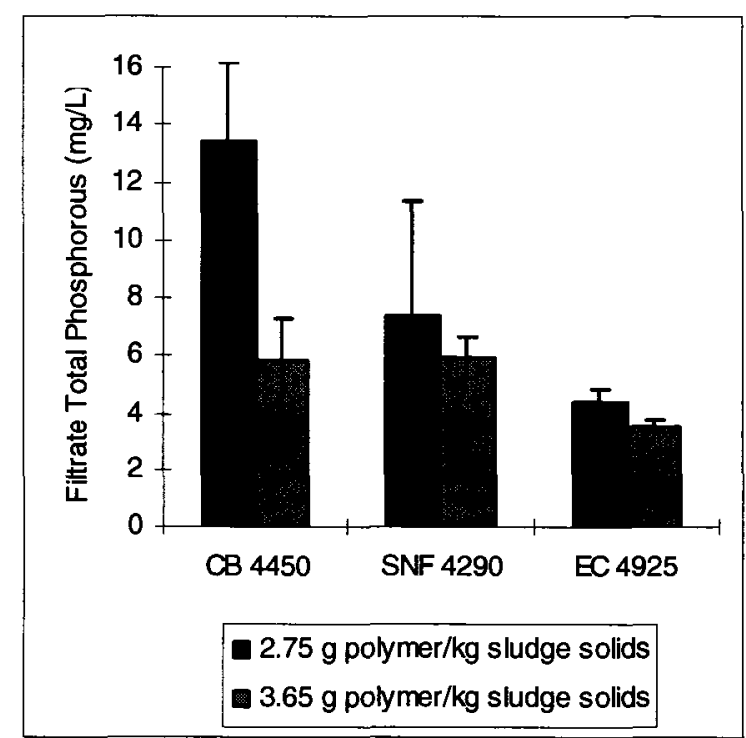

Figure 4.26 - Full-Scale Filtrate Total

Phosphorous; $n=6$ 


\subsubsection{Summary of Polymer Optimization}

In general, the overall advantage in selecting one polymer over another seems to disappear at higher polymer doses. At low polymer doses, however, the trial polymers SNF 4290 and EC 4925 outperformed the incumbent polymer. Achieving thickened sludge with over 4 percent solids is possible with the trial polymers at a dose approximately 25 percent less than the incumbent polymer. The picture is slightly more complicated when the nutrient selection is considered. At the lower dose of $2.75 \mathrm{~g}$ dry polymer per kilogram sludge solids, trial polymer SNF 4290 produced thickened sludge with approximately two and a half times higher TKN and total phosphorous concentration than the incumbent. At higher doses between 4.55 and $5.65 \mathrm{~g}$ dry polymer per kilogram sludge solids, the incumbent polymer produced thickened sludge with approximately 50 percent higher concentrations of TKN and total phosphorous. Filtrate turbidity was about five times lower during trials of SNF 4290 and EC 4925 than when the incumbent polymer was used, when the polymer dosage was $2.75 \mathrm{~g}$ dry polymer per kilogram sludge solids, but at higher doses the polymers performed approximately equally. At the $2.75 \mathrm{~g}$ dry polymer per kilogram sludge solids, the ammonia concentration of filtrate was about four times higher when the incumbent polymer was used versus the trial polymers, but the differences between polymer types fell within a one standard deviation at higher doses. Similarly, with respect to total phosphorous in filtrate, a significant difference between polymer types was observed only at the lower dose of $2.75 \mathrm{~g}$ dry polymer per kilogram sludge solids. The full-scale data from thickened sludge samples is summarized in Table 4.3, and the data from filtrate is presented in Table 4..4. 
Table 4.3 - Summary of Full-Scale Data - Thickened Sludge \pm 1 Standard Deviation

\begin{tabular}{|c|c|c|c|c|c|c|}
\hline $\begin{array}{l}\text { Dosage (g dry } \\
\text { polymer } / \mathrm{kg} \text { sludge } \\
\text { solids) } \rightarrow \\
\text { Parameter } \downarrow\end{array}$ & 1.85 & 2.75 & 3.65 & 4.55 & 5.45 & 6.35 \\
\hline \multicolumn{7}{|c|}{ Polymer CB 4450} \\
\hline Total Solids (\%) $n=6$ & N/A & $1.7 \pm 0.1$ & $4.9 \pm 0.8$ & $5.6 \pm 0.2$ & $5.9 \pm 0.2$ & $6.1 \pm 0.4$ \\
\hline $\begin{array}{l}\text { Total Phosphorous } \\
(\mathrm{mg} / \mathrm{kg}) \mathrm{n}=6\end{array}$ & N/A & $330 \pm 47$ & $960 \pm 100$ & $\begin{array}{c}1138 \pm \\
182 \\
\end{array}$ & $\begin{array}{c}1125 \pm \\
138\end{array}$ & $978 \pm 43$ \\
\hline TKN (mg/kg) n=6 & N/A & $988 \pm 68$ & $\begin{array}{c}2927 \pm \\
323\end{array}$ & $\begin{array}{c}3365 \pm \\
143\end{array}$ & $\begin{array}{l}3448 \pm \\
226\end{array}$ & $\begin{array}{c}3521 \pm \\
428\end{array}$ \\
\hline \multicolumn{7}{|c|}{ Polymer SNF 4290} \\
\hline Total Solids (\%) n=6 & $1.1 \pm 0.1$ & $4.3 \pm 0.3$ & $4.4 \pm 0.4$ & $4.9 \pm 0.8$ & $5.7 \pm 0.8$ & $6.0 \pm 0.4$ \\
\hline $\begin{array}{l}\text { Total Phosphorous } \\
(\mathrm{mg} / \mathrm{kg}) \mathrm{n}=6\end{array}$ & $723 \pm 65$ & $818 \pm 135$ & $869 \pm 64$ & $843 \pm 123$ & $820 \pm 108$ & $883 \pm 178$ \\
\hline TKN (mg/kg) n=6 & $\begin{array}{c}2185 \pm \\
264 \\
\end{array}$ & $\begin{array}{c}2453 \pm \\
479 \\
\end{array}$ & $\begin{array}{c}2603 \pm \\
267\end{array}$ & $\begin{array}{c}2452 \pm \\
392 \\
\end{array}$ & $\begin{array}{c}2493 \pm \\
282 \\
\end{array}$ & $\begin{array}{c}2695 \pm \\
500\end{array}$ \\
\hline \multicolumn{7}{|c|}{ Polymer EC 4925} \\
\hline Total Solids (\%) n=6 & $\begin{array}{c}3.7 \pm 0.3 \\
(\mathrm{n}=3)\end{array}$ & $4.4 \pm 0.4$ & $5.0 \pm 0.7$ & $5.0 \pm 0.5$ & $4.8 \pm 0.3$ & $4.8 \pm 0.7$ \\
\hline $\begin{array}{l}\text { Total Phosphorous } \\
(\mathrm{mg} / \mathrm{kg}) \mathrm{n}=6\end{array}$ & $\begin{array}{c}281 \pm 18 \\
(\mathrm{n}=3)\end{array}$ & $561 \pm 391$ & $862 \pm 78$ & $958 \pm 164$ & $975 \pm 149$ & $\begin{array}{l}1050 \pm \\
117\end{array}$ \\
\hline TKN (mg/kg) n=6 & $\begin{array}{c}606 \pm 29 \\
(n=3)\end{array}$ & $\begin{array}{c}1592 \pm \\
1131 \\
\end{array}$ & $\begin{array}{c}2480 \pm \\
499\end{array}$ & $\begin{array}{c}2715 \pm \\
556 \\
\end{array}$ & $\begin{array}{c}2895 \pm \\
598\end{array}$ & $\begin{array}{c}3162 \pm \\
412\end{array}$ \\
\hline
\end{tabular}

Table 4.4 - Summary of Full-Scale Data - Filtrate \pm 1 Standard Deviation

\begin{tabular}{|c|c|c|c|c|c|c|}
\hline $\begin{array}{l}\text { Dosage (g dry } \\
\text { polymer } / \mathrm{kg} \text { sludge } \\
\text { solids) } \rightarrow \\
\text { Parameter } \downarrow\end{array}$ & 1.85 & 2.75 & 3.65 & 4.55 & 5.45 & 6.35 \\
\hline \multicolumn{7}{|c|}{ Polymer CB 4450} \\
\hline Total Solids (\%) $\mathrm{n}=6$ & N/A & $\begin{array}{c}0.259 \pm \\
.160\end{array}$ & $\begin{array}{c}0.057 \pm \\
0.014\end{array}$ & $\begin{array}{c}0.059 \pm \\
0.019\end{array}$ & $\begin{array}{c}0.043 \pm \\
0.21\end{array}$ & $\begin{array}{c}0.068 \pm \\
0.08\end{array}$ \\
\hline $\begin{array}{l}\text { Total Phosphorous } \\
\text { (mg/L) n=6 }\end{array}$ & N/A & $13.4 \pm 2.8$ & $5.8 \pm 1.5$ & $6.3 \pm 1.1$ & $6.1 \pm 1.8$ & $6.9 \pm 3.2$ \\
\hline Ammonia (mg/L) $n=6$ & N/A & $2.3 \pm 0.8$ & $1.1 \pm 0.7$ & $1.2 \pm 0.7$ & $0.9 \pm 0.6$ & $0.5 \pm 0.1$ \\
\hline \multicolumn{7}{|c|}{ Polymer SNF 4290} \\
\hline Total Solids (\%) n=6 & $\begin{array}{c}0.363 \pm \\
0.131 \\
\end{array}$ & $\begin{array}{c}0.084 \pm \\
0.014 \\
\end{array}$ & $\begin{array}{c}0.061 \pm \\
0.011 \\
\end{array}$ & $\begin{array}{c}0.050 \pm \\
0.013 \\
\end{array}$ & $\begin{array}{c}0.043 \pm \\
0.019 \\
\end{array}$ & $\begin{array}{c}0.048 \pm \\
0.012 \\
\end{array}$ \\
\hline $\begin{array}{l}\text { Total Phosphorous } \\
\text { (mg/L) n=6 }\end{array}$ & $\geq 30$ & $7.4 \pm 4.0$ & $5.9 \pm 0.7$ & $4.1 \pm 1.1$ & $4.0 \pm 1.2$ & $5.7 \pm 1.2$ \\
\hline Ammonia $(\mathrm{mg} / \mathrm{L}) \mathrm{n}=6$ & $\geq 3.0$ & $0.7 \pm 0.2$ & $0.6 \pm 0.1$ & $0.3 \pm 0.1$ & $0.3 \pm 0.1$ & $0.4 \pm 0.1$ \\
\hline \multicolumn{7}{|c|}{ Polymer EC 4925} \\
\hline Total Solids (\%) n=6 & $\begin{array}{c}0.071 \pm \\
0.01(\mathrm{n}=3)\end{array}$ & $\begin{array}{c}0.048 \pm \\
0.021 \\
\end{array}$ & $\begin{array}{c}0.052 \pm \\
0.016 \\
\end{array}$ & $\begin{array}{c}0.066 \pm \\
0.007 \\
\end{array}$ & $\begin{array}{c}0.060 \pm \\
0.006 \\
\end{array}$ & $\begin{array}{l}0.061 \pm \\
0.005\end{array}$ \\
\hline $\begin{array}{l}\text { Total Phosphorous } \\
(\mathrm{mg} / \mathrm{L}) \mathrm{n}=6\end{array}$ & $\begin{array}{c}8.7 \pm 0.8 \\
(n=3)\end{array}$ & $4.4 \pm 0.4$ & $3.6 \pm 0.3$ & $3.4 \pm 1.3$ & $4.3 \pm 1.0$ & $3.9 \pm 0.6$ \\
\hline Ammonia (mg/L) n=6 & $\begin{array}{c}1.0 \pm 0.3 \\
(n=3)\end{array}$ & $0.4 \pm 0.2$ & $0.4 \pm 0.01$ & $0.4 \pm 0.03$ & $0.4 \pm 0.02$ & $0.5 \pm 0.02$ \\
\hline
\end{tabular}


At doses above $3.65 \mathrm{~g}$ dry polymer per $\mathrm{kg}$ sludge solids in almost every case, the polymers seem to exhibit similar performance. The only exception was when the TKN and total phosphorous concentrations of thickened sludge were examined at relatively high polymer doses, where the incumbent polymer outperformed the trial polymers. Therefore, this study only found simultaneous advantages in solids and nutrient delivery at low polymer doses.

\subsection{Clarifier Foaming}

\subsubsection{Microscope Analysis}

In this section, the focus is on characterizing a foaming problem that exists in the clarification basins at Crystal Beach WWTP. The clarifiers are designed to let solids in the activated sludge settle out of suspension, so that sludge may be collected, and the clarified liquid may be separated from the sludge solids. Foaming problems cause sludge to float on the clarifier surfaces, causing operational problems and impacting the quality of the effluent liquid that exits the clarifiers. Microscope analysis of the foam is useful to identify the types of microbes present in the foam, which is useful as a first step towards characterizing the nature and causes of the foaming problem (Jenkins et al., 2004; Richard, 2003). The samples used in this study were obtained from the surface of clarification and aeration basins, as well as from GBT filtrate, from WAS storage tanks, and from raw influent. The samples used from the clarification basin surfaces were used to characterize the foaming problem directly. The samples taken from aeration basins were used to determine the relative abundance of foam-causing microorganisms in 
surface foam versus in the bulk liquid. This comparison is useful to determine the microbial culprit(s) that can be implicated as causative factors in foaming issues, (Jenkins et al., 2004; Richard, 2003; Parker et al., 2003). The samples obtained from GBT filtrate, WAS storage tanks, and raw influent were used to determine whether foam-causing microorganisms were recycled through the plant during thickening, proliferating in sludge storage before thickening, or introduced from an exogenous source. Table 4.5 summarizes the major findings of the microscope analysis.

Table 4.5 - Summary of Findings of Microscope Analysis

\begin{tabular}{|c|c|c|}
\hline Sample Location & Foam Causing Microbes & Conclusion(s) \\
\hline Clarifier Surface & $\begin{array}{l}\text { Nocardia (excessive) } \\
\text { Type } 0041 \text { (very common) } \\
\text { Beggiatoa (rare) }\end{array}$ & $\begin{array}{l}\text { Foaming in } \begin{array}{l}\text { clarifiers } \\
\text { characteristic } \\
\text { foaming. Type }\end{array} \text { o041 also present } \\
\text { in foam }\end{array}$ \\
\hline Clarifier Bulk Liquid & Nocardia (few) & $\begin{array}{l}\text { Foam may be floating from } \\
\text { trapping locations at clarifier } \\
\text { inlets }\end{array}$ \\
\hline Aeration Foam & $\begin{array}{l}\text { Nocardia (common) } \\
\text { Type } 0041 \text { (few) }\end{array}$ & $\begin{array}{l}\text { Fewer Nocardia and Type } 0041 \\
\text { in aeration suggest growth } \\
\text { between aeration } \\
\text { clarification, possibly foam } \\
\text { trapping }\end{array}$ \\
\hline Aeration Liquid & Nocardia (few) & $\begin{array}{l}\text { Fewer Nocardia in bulk liquid } \\
\text { suggests stable foam }\end{array}$ \\
\hline Raw Sewage & None & $\begin{array}{l}\text { Foaming microbes endogenous to } \\
\text { plant }\end{array}$ \\
\hline WAS Storage & None & $\begin{array}{l}\text { Foaming microbes not } \\
\text { proliferating in sludge storage }\end{array}$ \\
\hline GBT filtrate & None & $\begin{array}{l}\text { Foaming microbes not recycled in } \\
\text { filtrate from thickening }\end{array}$ \\
\hline
\end{tabular}

* See Appendix 1 for summary of filamentous organisms and classification of abundance

Figures 4.29 to 4.32 show the photographs obtained from the microscopic analysis of clarifier foam. These figures are used to identify the types of filamentous bacteria that dominate the foam (Jenkins et al., 2004). Since different types of filamentous bacteria are known to thrive under specific conditions, process adjustment can be used to cause 
conditions in the plant that may cause physical stress to targeted filamentous bacteria (Jenkins et al, 2004; Parker et al., 2003; Iwahori et al., 1997).

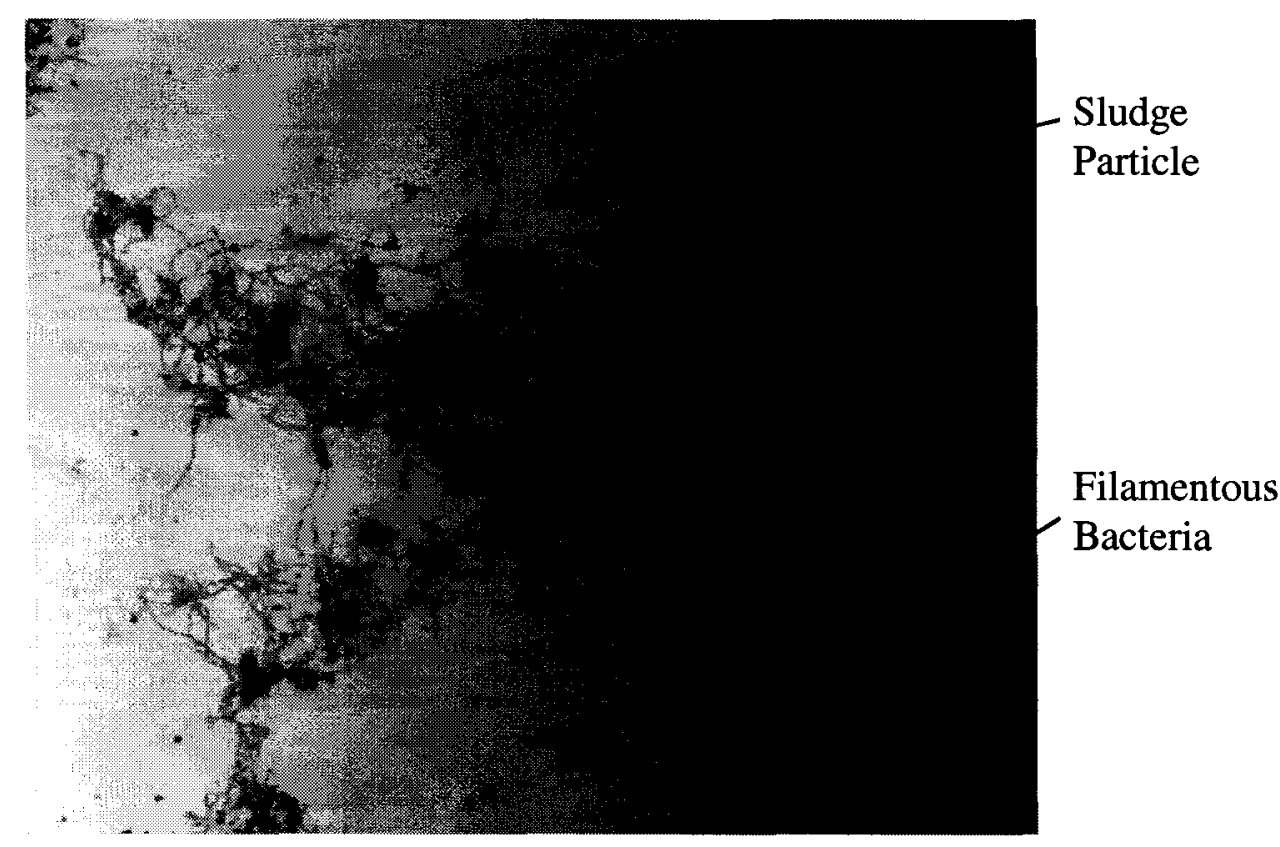

Figure 4.27 - Dilute Clarifier Foam - 100 Times Magnification

The foam shown in Figure 4.27 is mixed with clarifier liquid, and is somewhat dilute compared to the thick surface foam. The sample contains a noticeable amount of filamentous bacteria. The dark spots are sludge particles, which appear to be enmeshed within the filamentous structure of the bacteria. The filaments can become entangled, causing bridging between sludge particles, and forming large, loose clumps that do not settle easily (Frigon et al., 2006; Jenkins et al., 2004; Richard, 2003; Baumann et al., 1988). 


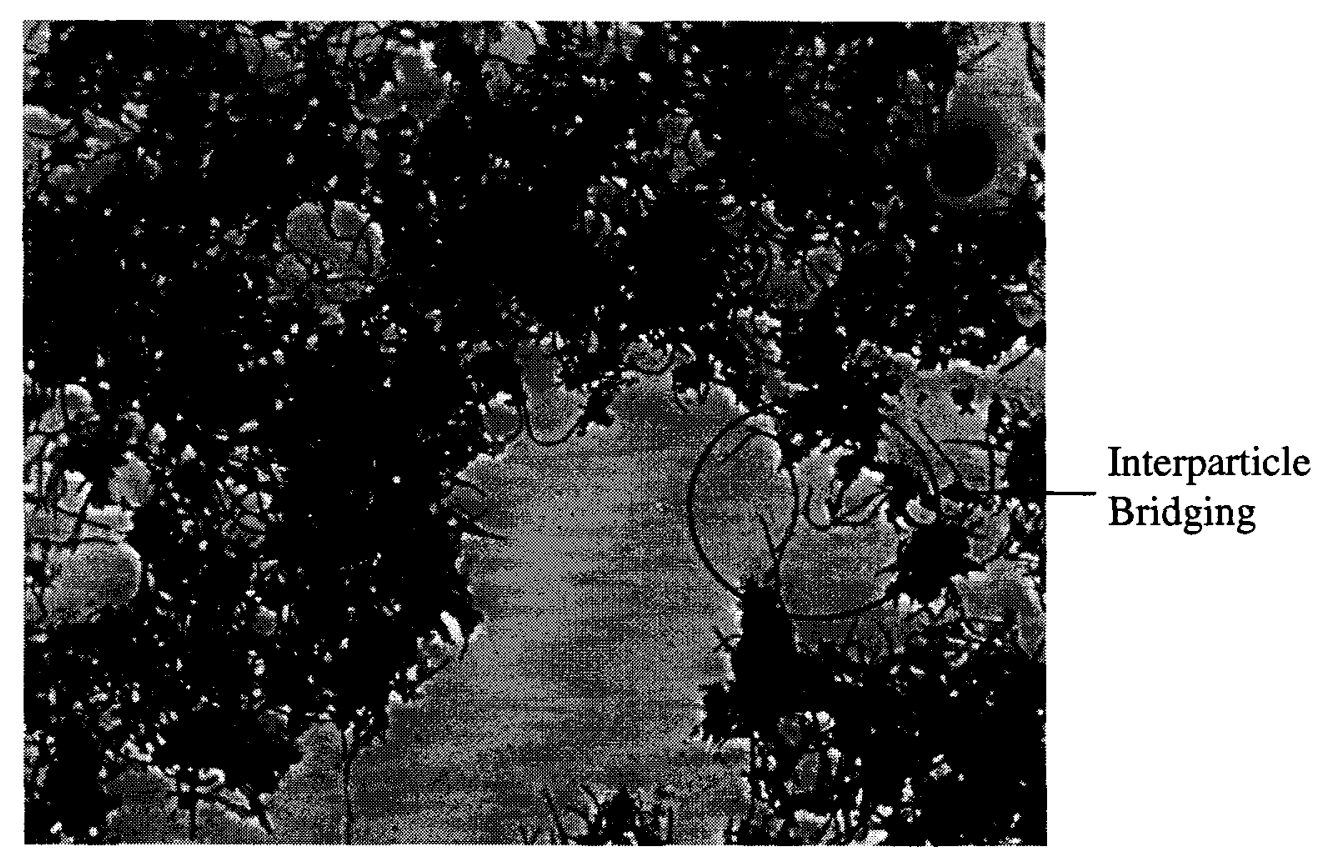

Figure 4.28 - Dilute Clarifier Foam - 100 Times Magnification, Gram Stained

The photograph shown in Figure 4.28 shows a similar mixed foam and liquid sample as in Figure 4.27. This microscope slide shows the effect of gram-staining, which makes the bacteria easier to identify against the background. From this photo, it is possible to determine that the foam is dominated by Nocardia bacteria. These are gram-positive bacteria that stain a dark colour against the background, and exhibit branching physiology (Eales et al., 2005; Jenkins et al., 2004). The bridging mechanism by which the filamentous bacteria can cause sludge particles to become enmeshed into larger particles is also evident. The filamentous bacteria form dense mats of intertwined bacteria. 


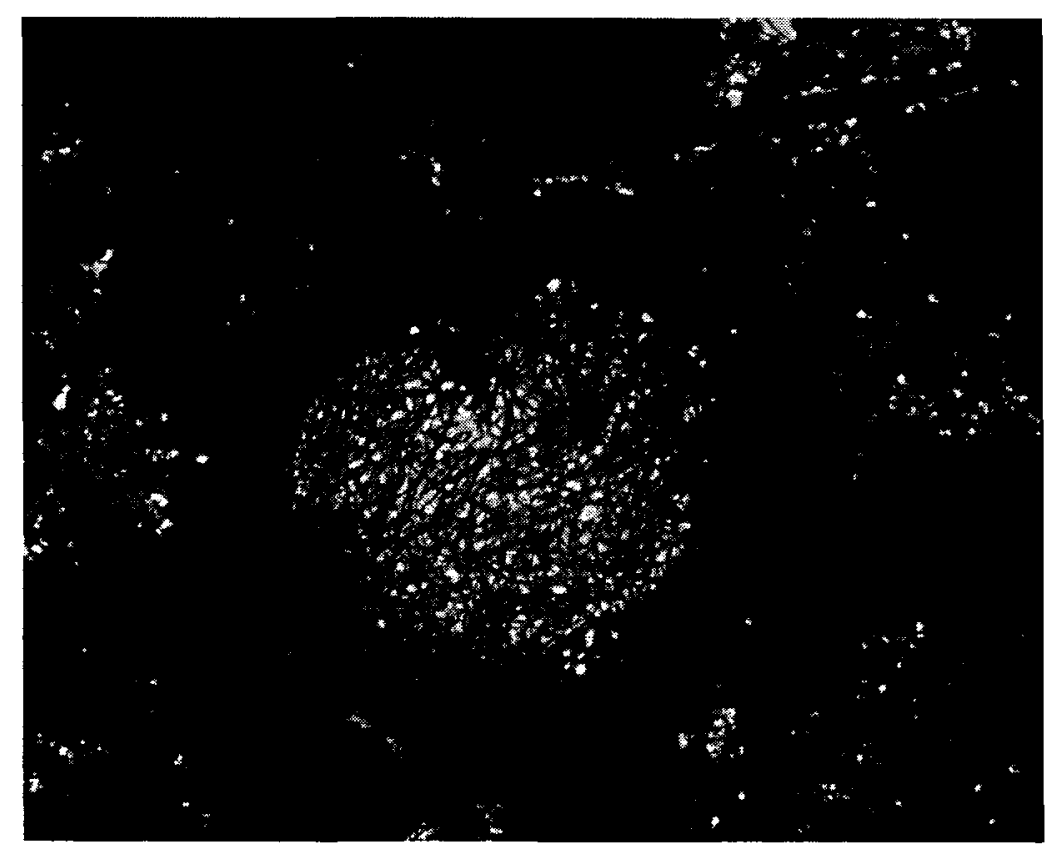

Figure 4.29- Clarifier Foam - 100 Times Magnification, Gram Stained

In Figure 4.29, the thick, floating foam from the clarifier surface is shown at 100 times magnification after gram staining. It appears that the thick foam is formed mainly of large masses of attached filamentous bacteria. An air bubble at the center of the figure helps show how dense the bacterial colony is within the thick surface foam. 


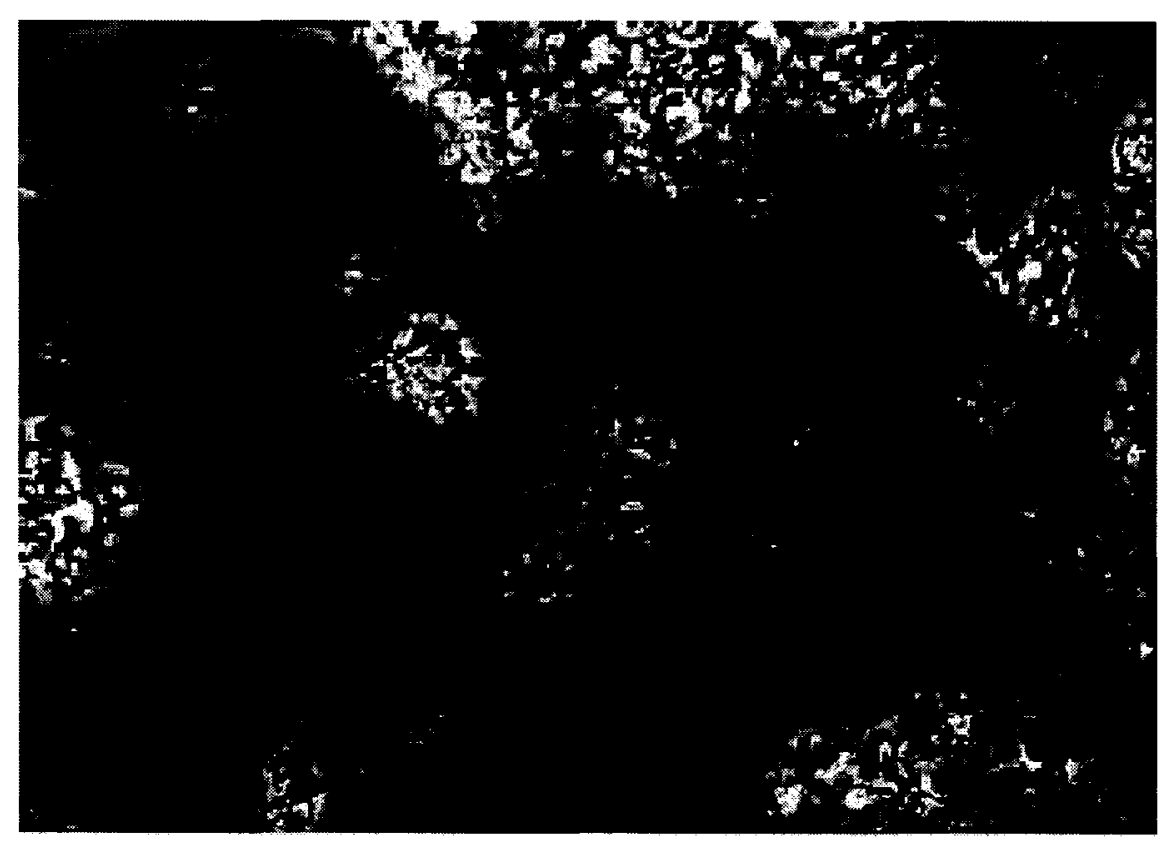

Figure 4.30 - Clarifier Foam at 100 times magnification, Phase Contrast

In Figure 4.30, the branching physiology of the filamentous bacteria is shown by observing the slide using a phase contrast light filter. The dense, brightly coloured sludge particles are entwined within a network of dark, branching bacterial hyphae. This is thought to hamper settling, and may also cause sludge bulking, (Jenkins et al., 2004; Richard, 2003). 


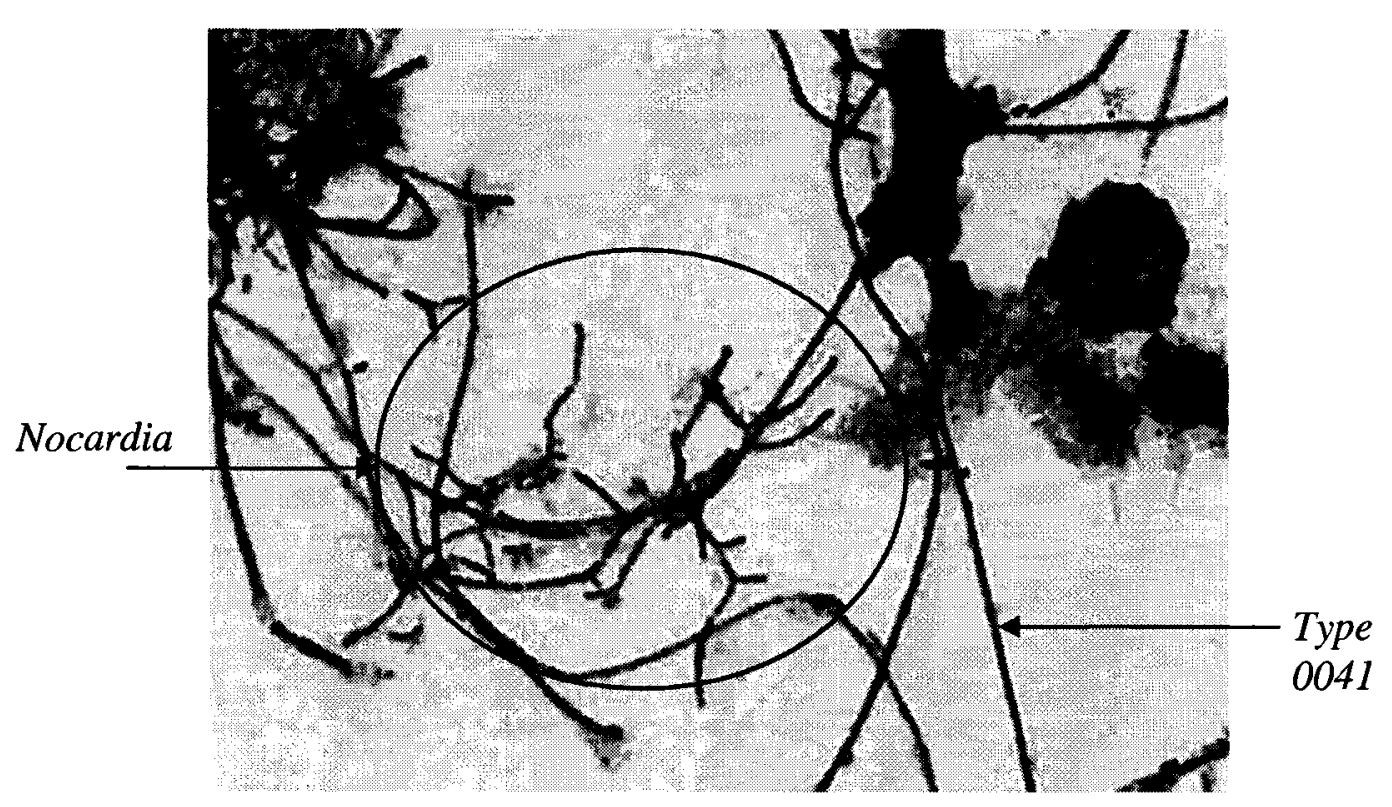

Figure 4.31 - Clarifier Foam - 1000 Times Magnification, Gram Stained

Figure 4.31 shows the filamentous bacteria at 1000 times magnification. At this magnification, it is possible to identify two specific species in the clarifier foam. The bacterium in the center exhibits gram-positive staining characteristics, (appearing purple), and true branching, characteristic of Nocardia bacteria. The longer, gently curving bacteria that exhibit gram-variable staining, (appearing purple and orange), are identified as type 0041 bacteria (Jenkins et al., 2004).

Microscopic analysis of samples taken from the plant influent, the waste activated sludge storage, and the filtrate from sludge thickening showed very little filamentous bacteria. This suggests that the filamentous bacteria responsible for the observed foaming originate in the activated sludge system, and do not survive well in other parts of the process stream. Because the sample from the plant headworks was free of filamentous bacteria, it 
appears that the filamentous bacteria are endogenous to the plant, and not imported within raw influent.

\subsubsection{E. Coli Enumeration Analysis}

Figure 4.32 shows the results of $E$. coli testing of foam from the aeration and clarification systems, and clarifier effluent. The Ontario regulation for plant effluent is shown with a red line. Practically, the disinfection process that occurs after clarification must bring the E. coli concentration from about $10^{5} \mathrm{cfu} / 100 \mathrm{~mL}$ down to the regulatory limit of 200 $\mathrm{cfu} / 100 \mathrm{~mL}$. The data suggests that the clarifier foam is a potent source of $E$. coli, approximately 100 times as concentrated in $E$. coli colony forming units than the clarifier effluent, and approximately fifty thousand times more concentrated than regulations permit in plant effluent. In other words, at Crystal Beach, it seems that foam mixes with bulk liquid from the clarifiers, and the $E$. coli concentration observed is approximately four orders of magnitude higher than the certificate of approval objective for effluent $E$. coli concentration. This suggests that the foam may increase the need for chlorine disinfection to kill $E$. coli and maintain compliance. At this point, there does not appear to be an abundance of literature sources that have examined the connection between sludge foaming and elevated levels of $E$. coli and/or suspended solids in clarifier effluent. Future work may be directed towards specifically measuring how foaming problems impact the quality of clarifier effluent, and discovering important mechanisms that may be at work. For example, it is not understood whether activated sludge foam is high in $E$. coli due to the presence of sludge particles within the foam matrix, or whether $E$. coli is able to proliferate in the foam layer. 


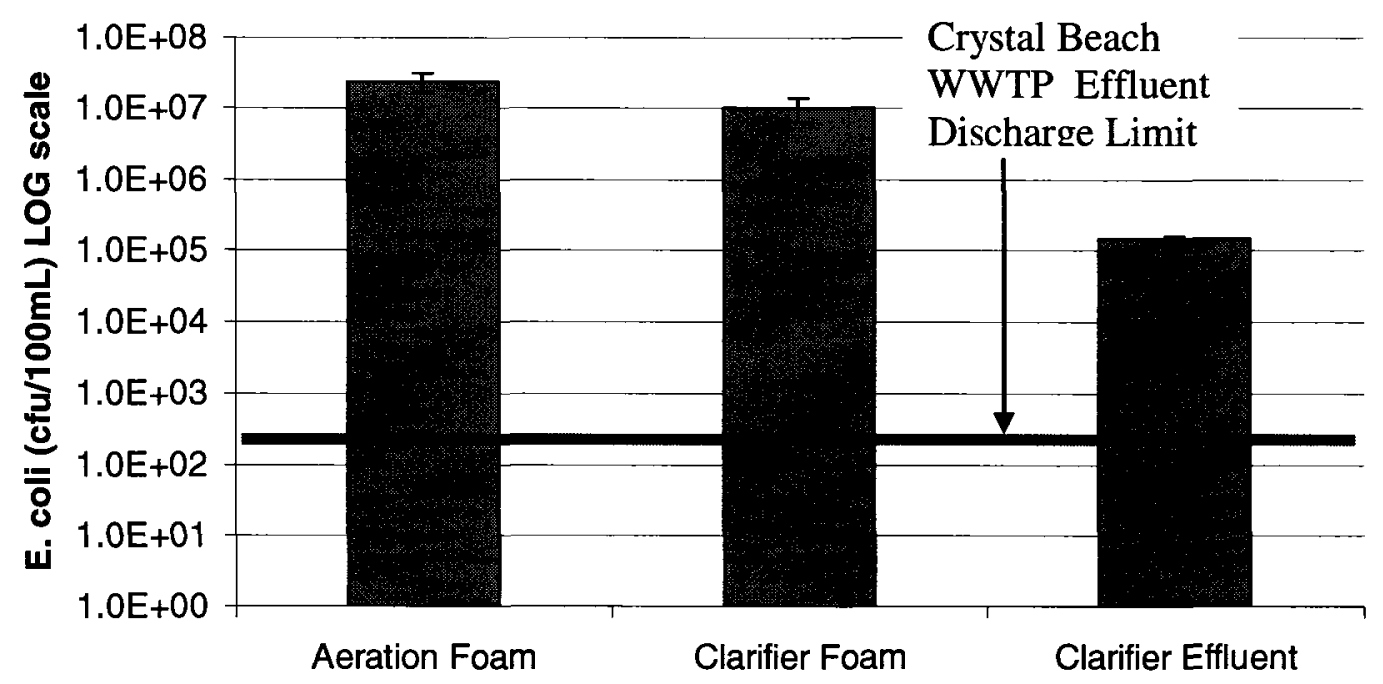

Figure 4.32 - E. coli Concentration at Three Different Sample Locations (n=3)

\subsubsection{Process Data Analysis}

Some research has suggested that both Nocardia and type 0041 thrive when SRT is too long, temperature is too high, the F/M ratio is too low, and the dissolved oxygen (DO) concentration is erratic, (Frigon et al., 2006; Jenkins et al., 2004; Parker et al., 2003; Scruggs and Randall, 1998; Kappeler and Brodmann, 1995; Blackall et al., 1991; Wanner and Grau, 1989; Baumann et al., 1988; Lemmer and Baumann, 1988). Using data from plant records, analysis was performed to determine whether the conditions at the plant are conducive to filamentous bacteria growth and may potentially allow foaming problems to occur. Figure 4.33 shows the SRT observed at Crystal Beach WWTP in 2006. This parameter represents the average amount of time that activated sludge solids reside in the aeration and clarification systems. The red line represents a conventional design 
parameter of eight days. Some studies suggest that in plants susceptible to filamentous bacteria foaming, SRT should be set as low as two days, (Jenkins et al., 2004; Blackall et al., 1991). Crystal Beach WWTP, however has an extended aeration system, which keeps organics and microorganisms under aeration for a greater period of time, in order to allow microorganisms to metabolize more organic matter. The SRT levels maintained at these types of plants is commonly longer, as high as 25 days (Metcalf and Eddy, 2005). However, because Crystal Beach does have foaming problems, and because higher SRTs are not maintained in order to allow nitrification-denitrification reactions to occur, (since Crystal Beach WWTP does not have regulated ammonia limits for the effluent), it has historically been operated with an eight day SRT target. The data shown in Figure 4.33 suggest that there is significant variability in the SRT maintained in the activated sludge system at Crystal Beach WWTP. Because the automatic flow meters that regulate SRT do not operate properly, it is difficult for operators to maintain a consistent SRT. This is an important point, since an erratic SRT has been implicated as a exacerbating factor in plants susceptible to Nocardia foaming problems (Jenkins et al., 2004). Providing operators with the ability to automate and analyze parameters such as SRT may allow the plant to maintain consistent conditions under which foaming is less likely to continue. 


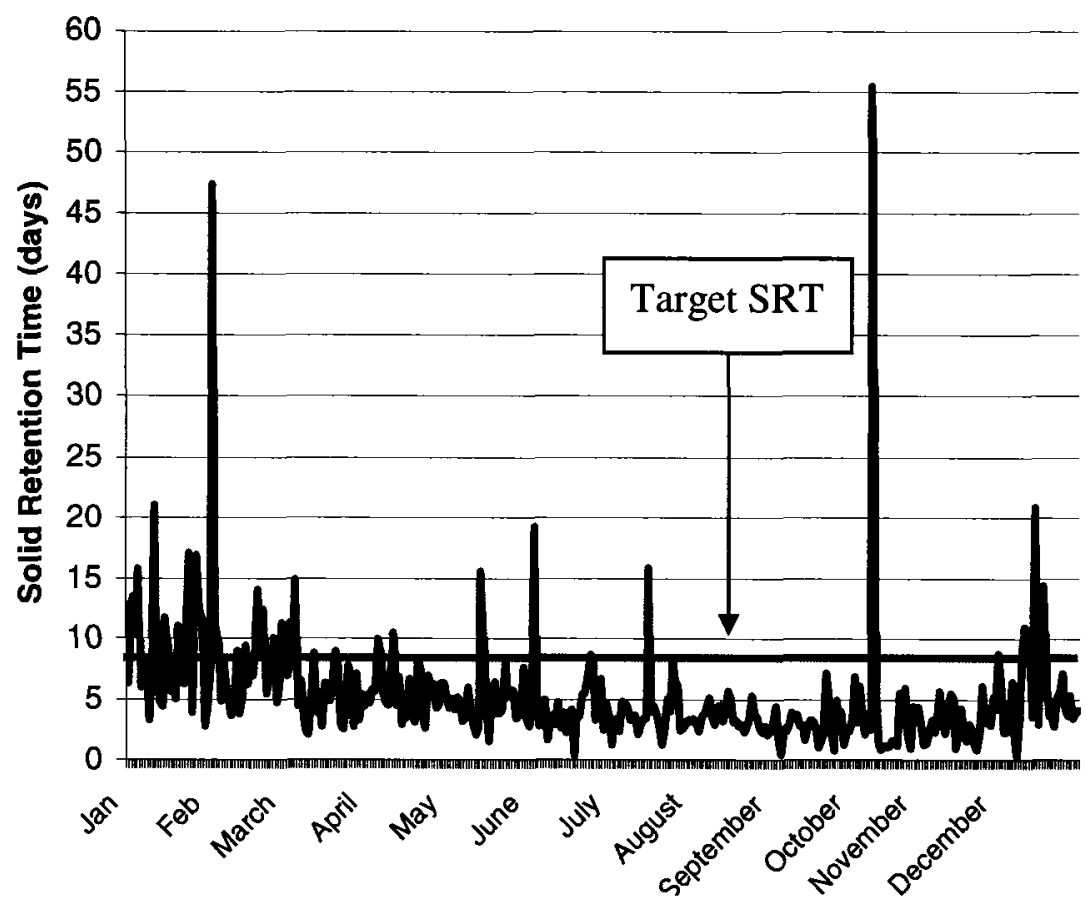

Figure 4.33 - Solid Retention Time Observed at Crystal Beach WWTP 2006

In Figure 4.34, the F/M ratio at Crystal Beach WWTP is shown. The red line shows the maximum F/M prescribed by the design parameters for extended aeration plants of 0.15 mg CBOD/mg mixed liquor volatile suspended solids. It is apparent that Crystal Beach WWTP tends to operate well above the designed F/M ratio, and exhibits a highly variable measured F/M ratio. By controlling SRT, and maintaining a range of values that is adjusted automatically instead of manually, related parameters such as $\mathrm{F} / \mathrm{M}$ will also become less variable. The F/M ratio data does not appear to support the assumption that Nocardia bacteria proliferate under low F/M conditions. However, conventional activated sludge plants without extended aeration typically maintain $\mathrm{F} / \mathrm{M}$ values around $0.3 \mathrm{mg} \mathrm{CBOD} / \mathrm{mg}$ MLVSS, (Metcalf and Eddy, 2005). Crystal Beach WWTP may 
behave more like a typical conventional activated sludge plant, in which case, the observed F/M may periodically be lower than ideal.

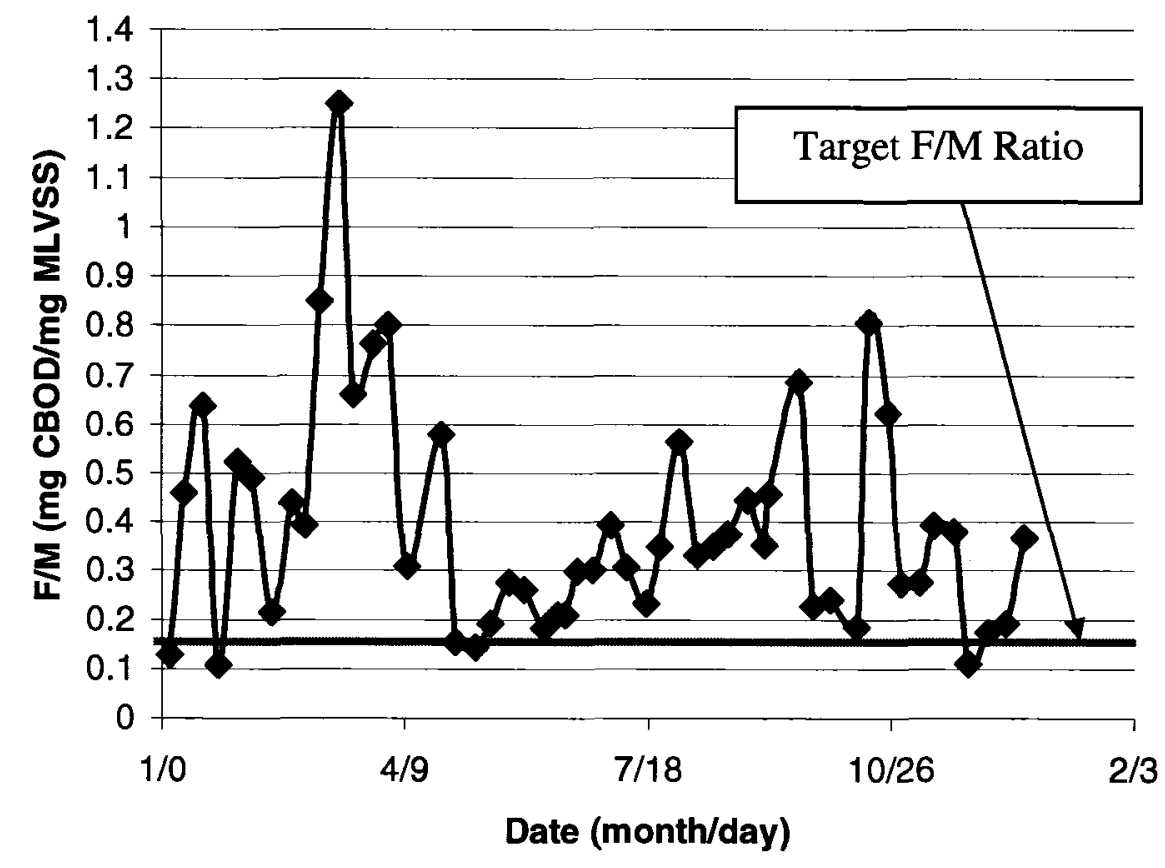

Figure 4.34 - F/M Ratio Observed at Crystal Beach WWTP 2006

Figure 4.35 shows the dissolved oxygen concentration in the aeration system at Crystal Beach WWTP observed over a three-week period in December 2006. Scruggs and Randall (1998) noted that scum causing Nocardia bacteria was enhanced by DO concentrations above $1.0 \mathrm{mg} / \mathrm{L}$, and that growth of Nocardia increased linearly with DO concentration as DO increases from 1.0 to $5.0 \mathrm{mg} / \mathrm{L}$. Jenkins et al., (2004) suggested that the filamentous bacteria type 0041 may thrive in conditions with erratic DO concentration. The DO data in Figure 4.35 reveals that the DO concentration reaches up 
to $8 \mathrm{mg} / \mathrm{L}$, and that the concentration is also somewhat erratic, fluctuating up to $2 \mathrm{mg} / \mathrm{L}$ in the interval shown. The design DO concentration for the plant is $2.0 \mathrm{mg} / \mathrm{L}$.

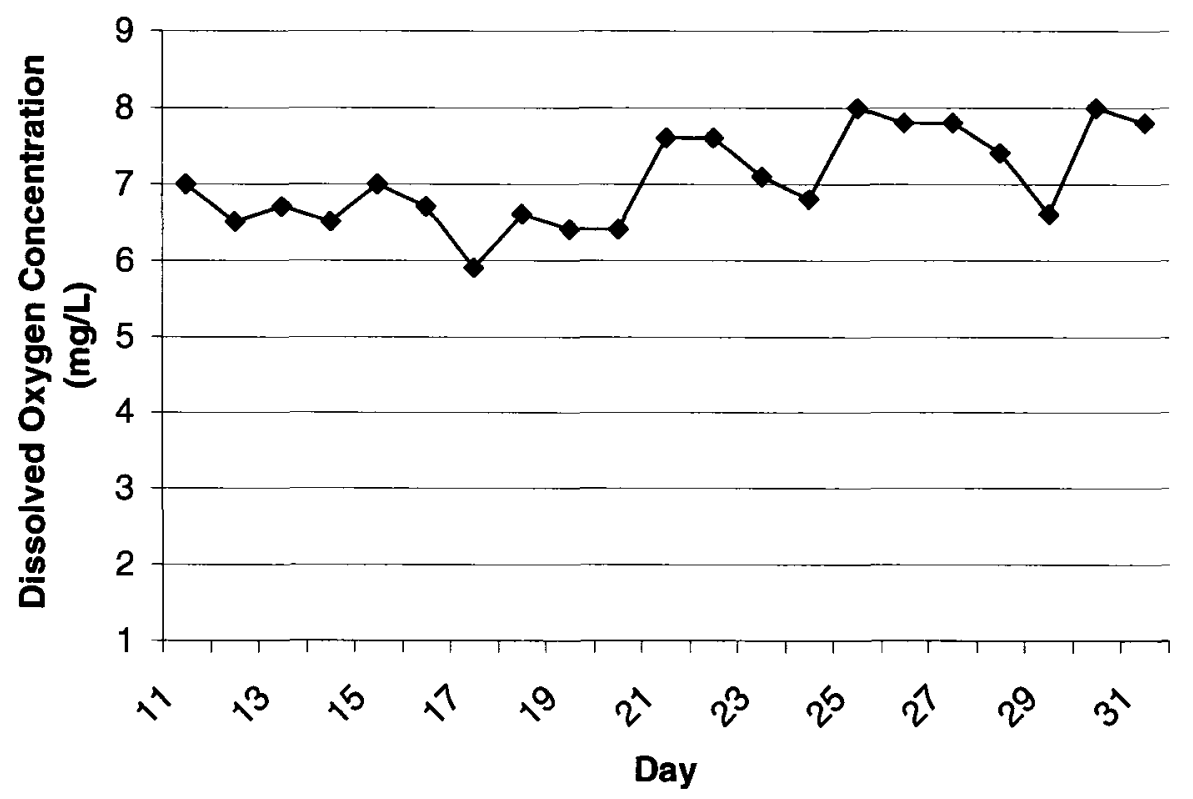

Figure 4.35 - Dissolved Oxygen Concentration Observed at Crystal Beach WWTP December 2006

The process data is summarized in Table 4.6, along with suggested design parameters. The data is listed by average, and the range observed over a given period of time is listed, to show the variability observed. 
Table 4.6 - Summary of Process Parameter Records at Crystal Beach WWTP

\begin{tabular}{|l|l|l|l|l|l|}
\hline Parameter & $\begin{array}{l}\text { Time } \\
\text { Interval }\end{array}$ & $\begin{array}{l}\text { Average } \\
\text { Value }\end{array}$ & Range & Recommended Value & Source(s) \\
\hline SRT & 2006 & 5.30 & $\begin{array}{l}0.31- \\
55.45\end{array}$ & $\begin{array}{l}8.0 \text { (design) } \\
2.0 \text { (to wash out foam) }\end{array}$ & $\begin{array}{l}\text { Jenkins } \text { et al., } \\
\text { 2004; Blackall } \\
\text { et al., } 1991\end{array}$ \\
\hline F/M & 2006 & 0.32 & $0.05-$ & $\begin{array}{l}0.15 \text { (design standard for extended } \\
\text { aeration) } \\
0.3 \text { (design standard for } \\
\text { conventional WWTP) }\end{array}$ & $\begin{array}{l}\text { Metcalf and } \\
\text { Eddy, 2003 }\end{array}$ \\
& & & 0.86 & $\begin{array}{l}<1.0 \text { (to combat foam microbes) } \\
2.0 \text { (design standard) }\end{array}$ & $\begin{array}{l}\text { Scruggs and } \\
\text { Randall, 1998 }\end{array}$ \\
\hline DO & $\begin{array}{l}\text { December } \\
2006\end{array}$ & 7.1 & $5.9-8.0$ & &
\end{tabular}

\subsubsection{Control of Clarifier Foaming}

To control the observed clarifier foaming problem at Crystal Beach WWTP, a number of methods have been recommended for the future. To reduce the generation time of filamentous bacteria in the activated sludge, the SRT must be controlled and reduced. An examination of the plant revealed that stabilizing SRT automatically is not currently possible. This is due to the current configuration of the sludge return and wasting equipment. Setting an automatic SRT will require that the sludge return rate is set as a proportion of wastewater influent flow, which at present is not possible due to poorly functioning flow meters and automatic valves at critical locations in the plant. Setting an automatic SRT will also regulate the F/M ratio, since Crystal Beach is known to receive influent at a relatively consistent CBOD concentration, probably because the influent is made up mainly of domestic wastewater.

The DO concentration must be regulated as well, and lowered to the design concentration of $2.0 \mathrm{mg} / \mathrm{L}$. At present, this is not possible because the valves from the blowers to the diffusers in the aeration system will not allow the air flow to be manipulated. Also, the 
blowers in use at the plant are oversized, and so excess air is delivered to the aeration cells. Reduction and proper control of DO concentration will require automatically controlled valves that adjust air input according to the DO levels measured in the aeration cells.

\subsubsection{Summary of Clarifier Foaming Research}

The major benefit of the clarifier foaming study was to provide information that did not exist previously. The persistent foaming problem was known to occur year-round, and was characterized by thick, brown, viscous foam that re-established itself after manual removal. The foam was known to cause activated sludge to float on the surface of the clarifiers, and was thought to increase the demand for chlorine in the disinfection process. The microscope analysis provided the necessary information to determine the dominant types of filamentous bacteria in the foam, and to rule out recycling and proliferation of filamentous bacteria in the plant in areas other than the clarification and aeration systems. Furthermore, the microscope analysis showed that the bacteria responsible for foaming were not imported to the plant in the raw influent, but rather were growing within the plant. After identifying the dominant bacteria in the foam (such as Nocardia), it was possible to consult literature sources that suggested specific conditions under which particular species can persist and proliferate. An examination of plant records suggested that important parameters such as SRT, F/M ratio, and DO may require adjustment and/or automation to maintain important target ranges that will make conditions less favourable for filamentous organisms and foaming incidents. In the future, the effectiveness of controlling process parameters at the plant may be documented, to show whether the 
foaming problem could be solved using a process-based approach, and to underscore the importance of taking an exhaustive approach that begins primarily with characterization of the microbiological community in the foam, and in the plant at various points in the process stream.

The E. coli analysis proved that the foam was a potent source of $E$. coli bacteria, approximately four orders or magnitude higher in $E$. coli colony forming units than the plant effluent discharge limit. In the future, an analysis of the effect of foaming on the chlorine demand on the disinfection process may prove that eradicating foaming problems is more important than simply rectifying a nuisance, but also a way to lower cost economically by lowering chlorine demand, and environmentally by lowering the amount of chlorine introduced into the natural aquatic environment. 


\section{Conclusions}

This research was aimed at improving the solids handling at a domestic WWTP by focusing on two main studies:

1.) Identifying the performance of a number of commercially available polymers in an existing sludge thickening system.

2.) Characterizing and recommending possible control strategies to combat a persistent, year round foaming problem that causes activated sludge to float on clarifier surfaces.

The polymer study took a practical approach to investigating the performance of a number of polymers at bench and full-scale, both in terms of solids capture, and nutrient selection during phase separation. To pre-screen polymers for solids capture and nutrient testing, an oxidation-reduction test was used. Polymers were then tested on a bench-scale gravity filter. Solid and liquid samples were tested for a variety of physical and chemical parameters. Some polymers produced sludge with higher concentrations of TKN than others, although significant advantages in total phosphorous concentration of filtrate were unclear. Three polymers were tested at full-scale. The two trial polymers appeared to be more effective than the incumbent polymer at lower dosages with respect to both solids capture, and nutrient delivery to the thickened sludge. The data shows that at lower doses, the trial polymers produced thickened sludge higher in TKN concentration, and filtrate lower in ammonia concentration, compared to the incumbent polymer. At higher doses, however, the incumbent polymer was better than the trial polymer SNF 4920 at concentrating TKN in solid phase at doses over $3.65 \mathrm{~g}$ polymer per kilogram sludge solids. Trial polymer EC 4925 appeared to outperform the other two polymers at 
maintaining a low concentration of total phosphorous in filtrate, but only at doses below $3.65 \mathrm{~g}$ polymer per kilogram sludge solids. Overall, the trial polymers tested offer simultaneous advantages in both solids capture and nutrient selection at relatively lower doses than the incumbent polymer. The results confirm that polymer selection can influence nutrient delivery to thickened WAS, which does not appear to have been previously reported in literature.

The foaming research completed to date has proven that the foaming problem observed at Crystal Beach is due mainly to a persistent, endogenous population of Nocardia bacteria, (among other less dominant filamentous bacteria), that cause sludge separation problems in the aeration cells and clarification basins. The foam that floats on the clarification basins overwhelms the automatic scum removal system, and requires additional work hours for operators to remove scum from clarifier surfaces manually. The foam may also compromise the quality of the effluent, and has been shown to be a potent source of $E$. coli, which requires an excessive amount of sodium hypochlorite to be used for disinfection, increasing the chlorine residual delivered to the natural aquatic environment. This foaming phenomenon is believed to be due in large part to the environment maintained in the activated sludge system. This study has shown that the activated sludge system is characterized by somewhat variable conditions. The SRT, F/M ratio, and DO concentration, three standard measures of activated sludge system conditions, are historically erratic, and may be maintained far outside of the design ranges. As a result of these findings, recommendations have been made to impose controls on the activated sludge system, (especially the SRT), by automating sludge wasting and return, processes 
that currently are controlled manually, and maintaining a constant DO concentration in the aeration system that is within the design specifications of the plant. The clarifier foaming study was mainly focused on characterizing the problem, and so a follow-up study should be conducted to evaluate the effectiveness of the recommended control strategies. 


\section{References}

Al-Mutairi, N.Z., Hamoda, M.F., Al-Ghusain, I. (2004). Coagulant selection and sludge conditioning in a slaughterhouse wastewater treatment plant. Bioresource Technology 95, 115-119.

Al-Muzaini, S., Hamoda, M.F. (1998). Selection of an effective sludge dewatering system for a small wastewater treatment plant. Environment International, 25(8), 983990.

American Public Health Association/American Water Works Association. (1998). Standard methods for the examination of water and wastewater 20th edn

Atkins, P., Jones, L. (2005). Chemical Principles, $3^{\text {rd }}$ ed., W.H. Freeman and Company. New York.

Ayol1, A, Dentel, S.K., Filibeli, A. (2005). Dual polymer conditioning of water treatment residuals. Journal of Environmental Engineering.

Baumann, M., Lemmer, H., Ries, H. (1988) Scum actinomycetes in sewage treatment plants - part 1. Water Research, 22, 6, 755-759.

Benitez, J., Rodriguez, A., Suarez, A. (1994). Optimization technique for sewage sludge conditioning with polymer and skeleton builders. Water Research, 28(10), 2067-2073.

Blackall, L.L., Harbers, A.E., Greenfield, P.F., Hayward, A.C. (1991). Foaming in activated sludge plants: A survey in Queensland, Australia and an evaluation of some control strategies. Water Research, 25(3), 313-317.

Cha, D.K., Jenkins, D., Lewis, W.P., Kido, W.H. (1992). Process control factors influencing Nocardia populations in activated sludge. Water Environment Research, 64, 37.

Chen, G., Yue, P.L., Mujumder, A.S. (2002). Sludge dewatering and drying. Drying Technology, 20(4\&5), 883-916.

Chitikela, S., Dentel, S.K. (1998). Dual-chemical conditioning and dewatering of anaerobically digested biosolids: laboratory evaluations. Water Environment Research, 70(5), 1062-1069.

Deneux-Mustin, S., Lartiges, B.S., Villemin, G., Thomas, F., Yvon, J., Bersillon, J.L., Snidaro, D. (2001). Ferric chloride and lime conditioning of activated sludges: an 
electron microscopic study on resin embedded samples. Water Research, 35(12), 30183024.

Dentel, S.K., in: Spinosa L., Vesilind P.A. (Eds.), Sludge into biosolids, IWA Publishing, London, 2001, Chapter 16.

Dentel, S.K. (2001). Conditioning, thickening, and dewatering - research update/research needs. Water Science and Technology, 44(10), 9-18.

Droste, R.L. (1997). Theory and Practice of Water and Wastewater Treatment. John Wiley and Sons. Toronto.

Eales, K., Nielsen, J.L., Kragelund, C., Seviour, R., Nielson, P.H. (2005). The in-situ physiology of pine tree like organisms in activated sludge foams. Acta Hydrochimica et Hydrobiologica, 33(3), 203-209.

Eikelboom, D.H., Andreadakis, A., Andreasen, K. (1998). Survey of filamentous populations in nutrient removal plants in four European countries. Water Science and Technology, 37(4-5), 281-289.

Frigon, D., Guthrie, R.M., Bachman, G.T., Royer, J., Bailey, B., Raskin, L. (2006). Long term analysis of a full-scale activated sludge wastewater treatment system exhibiting seasonal biological foaming. Water Research, 40, 990-1008.

Government of Ontario. (2002). Nutrient management act. c.4, s.6 (2).

Government of Canada. (2003). Canada Gazette, Part II, 135(1) 143-153.

Iwahori, K., Taki, H., Miyata, N., Fujita, M. (1997). Analysis of nocardia amarae profiles in actual foaming activated sludge plant with viable cell count measurement. Journal of Fermentation and Bioengineering, 84, 98-102.

Jenkins, D., Richard, M.G., Daigger, G.T. (2004). Manual on the causes and control of activated sludge bulking and foaming. Lewis Publishers. $3^{\text {rd }}$ edition.

Jess, D. (2005). Secondary foam chlorination the easy way. Environmental Science and Engineering. January: 28.

Kappeler, J., Brodmann, R. (1995). Low F/M bulking and scumming: towards a better understanding by modelling. Water Science and Technology, 31(2), 225-234. 
Kappeler, J., Gujer, W. (1994). Scumming due to actinomycetes: toward a better understanding by modeling. Water Research, 28(4), 763-779.

Kiely, P. (1997). Environmental engineering. McGraw-Hill. NewYork

Knoop, S., Kunst, S. (1998). Influence of temperature and sludge loading on activated sludge settling, especially on Microthrix Parvicella. Water Science and Technology, 37(4-5), 37-45.

Krishnamurthy, S. and Viraraghavan, T. (2005). Chemical conditioning for dewatering municipal wastewater sludges. Energy Sources, Part A: Recovery, Utilization, and Environmental Effects, 27(1), 113 - 122.

Lemmer, H., Baumann, M. (1988). Scum actinomycetes in sewage treatment plantspart 2. Water Research, 22(6), 761-763.

Lemmer, H., Baumann, M. (1988). Scum actinomycetes in sewage treatment plants Part 3. Water Research 22(6), 765-767.

Lemmer, H., Lind, G., Muller, E., Schade, M., Ziegelmayer, B. (2000). Scum in activated sludge plants: impact of filamentous and non-filamentous bacteria. Acta Hydrochimico et Hydrobiologico 28(1), 34-40.

Lemmer, H. (1986). The ecology of scum causing actinomycetes in sewage treatment plants. Water Research 20(4), 531-535.

Mikkelsen, L.H., Keiding, K. (2001). Effects of solids concentration on activated sludge deflocculation, conditioning and dewatering. Water Science and Technology, 44(2-3), 417-26.

Metcalf and Eddy Incorporated. (2003) Wastewater engineering, treatment and reuse, $4^{\text {th }}$ edition. McGraw-Hill College Publications. New York

Novak, J.T., Agerbæk, M.L., Sørensen, B.L., Hansen, J.A. (1999). Conditioning, filtering, and expressing waste activated sludge. Journal of Environmental Engineering 125(9), 816-824. 
Oerther, D.B., De Los Reyes III, F.L., De Los Reyes, M.F., Raskin, L. (2001).

Quantifying filamentous microorganisms in activated sludge before, during, and after an incident of foaming by oligonucleotide probe hybridizations and antibody staining.

Water Research 35(14), 3325-3326.

Olezskiewicz, J.A., Mavinic, D.S. (2001). Wastewater biosolids: an overview of processing, treatment, and management. Canadian Journal of Environmental Engineering. 28, 102-114.

Olivier, J., Vaxelaire, J., Ginisty, P. (2004). Gravity drainage of activated sludge: from laboratory experiments to industrial process. Journal of Chemical Technology and Biotechnology. 79, 461-467.

Pagilla, K.R., Jenkins, D., Kido, W. (1998). Nocardia effects in waste activated sludge. Water Science and Technology. 38(2), 49-54.

Parker, D., Geary, S., Jones, G., McIntyre, L., Oppenheim, S., Pedregon, V., Pope, R., Richards, T., Voight, C., Volpe, G., Willis, J., Witzgall, R. (2003). Making classifying selectors work for foam elimination in the activated sludge process. Water Environment Research, 75(1), 83-92.

Richard, M. (2003). Activated sludge microbiology problems and their control. Presented at the $20^{\text {th }}$ Annual USEPA Nation Operator Training Conference. Buffalo, New York.

Saveyn, H.., Meersseman, S., Thas, O., Van der Meeren, P. (2005). Influence of polyelectrolyte characteristics on pressure-driven activated sludge dewatering. Colloids and Surfaces A: Physicochemical Engineering Aspects 262, 40-51

Scales, P.J., Lester, D., Dixon, D.R., in: Spinosa L., Vesilind P.A. (Eds.), Sludge into biosolids, IWA Publishing, London, 2001, Chapter 17.

Scruggs, C.E., Randall, C.W. (1998). Evaluation of filamentous microorganism growth factors in an industrial wastewater activated sludge system. Water Science and Technology, 37(4-5), 263-270.

Severin, B.F., Grethlein, H.E. (1996). Laboratory Simulation of belt press dewatering: application of the Darcy equation to gravity drainage. Water Environment Research. 68 (3), 359-369.

Severin, B.F., Nye, J.V., Kim, B.J. (1999). Model and analysis of belt drainage thickening. Journal of Environmental Engineering. 125 (9), 807-815. 
Shao, Y.J., Starr, M., Kaporis, K., Kim, H.S., Jenkins, D. (1997). Polymer addition as a solution to Nocardia foaming problems. Water Environment Research. 69, 25-27.

Sodell, J., Seviour, R. (1996). Growth of activated sludge foam-forming bacterium, Nocardia Pinensis on hydrophobic substrates. Water Science and Technology, 34(5-6), 113-118.

U.S. Environmental Protection Agency. (1987). Design manual: Dewatering municipal wastewater sludges, EPA-625/1-79-011, Washington, D.C.: Office of Research and Development, 37-55.

Vaxelaire, J., Olivier, J. (2006). Conditioning for municipal sludge dewatering. From filtration compression cell tests to belt press. Drying Technology, 24, 1225-1233.

Vesilind, P.A., Hartman, G.C., Skene, E.T. (1986). Sludge management and disposal for the practicing engineer. Lewis Publishers. Michigan.

Wanner, J., Grau, P. (1989). Identification of filamentous organisms from activated sludge: a compromise between wishes, needs, and possibilities. Water Resources, 23(7) 883-891.

Westlund, A.D., Hagland, E., Rothman, M. (1998). Foaming in anaerobic digesters caused by Microthrix Parvicella. Water Science and Technology, 37(4-5), 51-55. 


\section{Appendix 1 - Index of Filamentous Organisms}

This appendix identifies a selection of filamentous organisms that have been documented in studies that have explored the problems of activated sludge bulking and foaming. In Table A1.1, organisms are listed with their physical characteristics, conditions that may allow them to exist and/or proliferate, and some methods that may be useful to control their occurrence. In Table A1.2, a method from Jenkins et al. (2004), for characterizing the abundance of individual species during microscopic evaluation of samples is presented.

Table A1.1 - Filamentous Organisms that may Cause Sludge Bulking and/or Foaming

\begin{tabular}{|c|c|c|c|c|}
\hline Organism Name & Characteristics & Conditions & Control & Source \\
\hline Nocardioform & $\begin{array}{l}\text { Filaments with true } \\
\text { branching } \\
\text { morphology } 5 \text { to } 30 \\
\mu \mathrm{m} \text { in length }\end{array}$ & $\begin{array}{l}\text { Mixed aeration } \\
\text { systems; High } \\
\text { SRT/Low F/M; High } \\
\text { water temp. (above } 15 \\
\left.{ }^{\circ} \mathrm{C}\right) ; \text { Hydrophobic } \\
\text { substrates; Slowly } \\
\text { degradable substrates; } \\
\text { Oleic acid substrate; } \\
\text { Foam trapping }\end{array}$ & $\begin{array}{l}\text { Decrease mixing } \\
\text { in aeration } \\
\text { system; Decrease } \\
\text { SRT; Reduce } \\
\text { foam trapping }\end{array}$ & $\begin{array}{l}\text { Jenkins et al. } \\
2004 ; \\
\text { Richard, } \\
2003 \text {; } \\
\text { Lemmer et } \\
\text { al., 2000; }\end{array}$ \\
\hline Type 004I & $\begin{array}{l}\text { Straight filaments } \\
100 \text { to } 500 \mu \mathrm{m} \text { in } \\
\text { length; Gram } \\
\text { variable }\end{array}$ & $\begin{array}{l}\text { High SRT/Low F/M; } \\
\text { Slowly degradable } \\
\text { substrates }\end{array}$ & Decrease SRT & $\begin{array}{l}\text { Jenkins } \text { et al. } \\
2004 ; \\
\text { Richard, } \\
2003 ; \\
\text { Lemmer } \text { et } \\
\text { al., } 2000\end{array}$ \\
\hline Beggiatoa sp. & $\begin{array}{l}\text { Straight or curved } \\
\text { filaments } 100 \text { to } \\
500 \mu \mathrm{m} \text { in length; } \\
\text { Gram negative; } \\
\text { motile }\end{array}$ & $\begin{array}{l}\text { May be imported from } \\
\text { outside WWTP; Sulfide } \\
\text { substrate; Septicity }\end{array}$ & $\begin{array}{l}\text { Remove septic } \\
\text { conditions; } \\
\text { Discourage } \\
\text { attached growth } \\
\text { on septic } \\
\text { surfaces }\end{array}$ & $\begin{array}{l}\text { Jenkins } \text { et al. } \\
2004 ; \\
\text { Kappeler and } \\
\text { Gujer, } 1994\end{array}$ \\
\hline $\begin{array}{l}\text { Microthrix } \\
\text { Parvicella }\end{array}$ & $\begin{array}{l}\text { Coiled filaments } 50 \\
\text { to } 200 \mu \mathrm{m} \text {; Gram } \\
\text { positive }\end{array}$ & $\begin{array}{l}\text { High SRT/Low F/M; } \\
\text { Low DO; Low water } \\
\text { temp. (below } 10^{\circ} \mathrm{C} \text { ); } \\
\text { Hydrophobic } \\
\text { substrates; Slowly } \\
\text { degradable substrates; } \\
\text { Oleic acid substrate; } \\
\text { Foam trapping }\end{array}$ & $\begin{array}{l}\text { Decrease SRT; } \\
\text { Increase DO; } \\
\text { Reduce foam } \\
\text { trapping }\end{array}$ & $\begin{array}{l}\text { Jenkins } \text { et al. } \\
2004 ; \\
\text { Richard, } \\
2003 ; \\
\text { Lemmer } \text { et } \\
\text { al., 2000; }\end{array}$ \\
\hline Sphaerotilus Natans & $\begin{array}{l}\text { Straight or gently } \\
\text { curved filaments; }\end{array}$ & $\begin{array}{l}\text { Mixed aeration } \\
\text { systems; Low DO; }\end{array}$ & $\begin{array}{l}\text { Reduce mixing } \\
\text { in aeration }\end{array}$ & $\begin{array}{l}\text { Jenkins et al. } \\
\text { 2004; }\end{array}$ \\
\hline
\end{tabular}




\begin{tabular}{|c|c|c|c|c|}
\hline & $\begin{array}{l}100 \text { to } 500 \mu \mathrm{m} \text { in } \\
\text { length; Gram- } \\
\text { negative; non- } \\
\text { motile }\end{array}$ & $\begin{array}{l}\text { Phosphorus deficiency; } \\
\text { Simple sugar substrate; } \\
\text { May be imported from } \\
\text { outside the WWTP }\end{array}$ & $\begin{array}{l}\text { system; increase } \\
\text { DO; anoxic or } \\
\text { anaerobic } \\
\text { selectors }\end{array}$ & $\begin{array}{l}\text { Richard, } \\
2003 ; \\
\text { Kappeler and } \\
\text { Gujer, } 1994\end{array}$ \\
\hline Type 1701 & $\begin{array}{l}\text { Straight, curved or } \\
\text { bent filaments; } 10 \\
\text { to } 150 \mu \mathrm{m} \text { in } \\
\text { length; Gram- } \\
\text { negative }\end{array}$ & $\begin{array}{l}\text { Mixed aeration } \\
\text { systems; Low DO; } \\
\text { Simple sugar substrate; }\end{array}$ & $\begin{array}{l}\text { Reduce mixing } \\
\text { in aeration } \\
\text { system; increase } \\
\text { DO; anoxic or } \\
\text { anaerobic } \\
\text { selectors }\end{array}$ & $\begin{array}{l}\text { Jenkins et al. } \\
2004 ; \\
\text { Richard, } 2003\end{array}$ \\
\hline $\begin{array}{l}\text { Haliscomenobacter } \\
\text { hydrossis }\end{array}$ & $\begin{array}{l}\text { Straight or bent } \\
\text { filaments } 10 \text { to } 100 \\
\mu \mathrm{m} \text { in length; } \\
\text { Gram negative }\end{array}$ & $\begin{array}{l}\text { Mixed aeration } \\
\text { systems; Low DO; } \\
\text { Simple sugar substrate; } \\
\text { volatile fatty acid } \\
\text { substrate }\end{array}$ & $\begin{array}{l}\text { Reduce mixing } \\
\text { in aeration } \\
\text { system; increase } \\
\text { DO; anoxic or } \\
\text { anaerobic } \\
\text { selectors }\end{array}$ & $\begin{array}{l}\text { Jenkins } \text { et al. } \\
\text { 2004; } \\
\text { Richard, } 2003\end{array}$ \\
\hline Type 021N & $\begin{array}{l}\text { Curved filaments; } \\
50 \text { to } 500 \mu \mathrm{m} \text { in } \\
\text { length; Gram } \\
\text { negative }\end{array}$ & $\begin{array}{l}\text { Mixed aeration } \\
\text { systems; Nitrogen } \\
\text { deficiency; Volatile } \\
\text { fatty acid substrates; } \\
\text { Sulfide substrate; } \\
\text { Septicity; }\end{array}$ & $\begin{array}{l}\text { Reduce mixing } \\
\text { in aeration } \\
\text { system; increase } \\
\text { DO; anoxic or } \\
\text { anaerobic } \\
\text { selectors; } \\
\text { Remove septic } \\
\text { conditions } \\
\end{array}$ & $\begin{array}{l}\text { Jenkins et al. } \\
2004 ; \\
\text { Richard, } 2003\end{array}$ \\
\hline Thiothrix I & $\begin{array}{l}\text { Straight or curved } \\
\text { filaments } 100 \text { to } \\
500 \mu \mathrm{m} \text { in length; } \\
\text { Gram negative, but } \\
\text { may stain Gram } \\
\text { positive when } \\
\text { sulphide present }\end{array}$ & $\begin{array}{l}\text { Nitrogen deficiency; } \\
\text { Volatile fatty acid } \\
\text { substrate; Sulfide } \\
\text { substrate; Septicity; }\end{array}$ & $\begin{array}{l}\text { Remove septic } \\
\text { conditions }\end{array}$ & $\begin{array}{l}\text { Jenkins } \text { et al. } \\
\text { 2004; } \\
\text { Richard, } 2003\end{array}$ \\
\hline Thiothrix II & $\begin{array}{l}\text { Straight or curved } \\
\text { filaments } 50 \text { to } 200 \\
\mu \mathrm{m} \text { in length; } \\
\text { Gram negative, but } \\
\text { may stain Gram } \\
\text { positive when } \\
\text { sulphide present }\end{array}$ & $\begin{array}{l}\text { Nitrogen deficiency; } \\
\text { Volatile fatty acid } \\
\text { substrate; Sulfide } \\
\text { substrate; Septicity; }\end{array}$ & $\begin{array}{l}\text { Remove septic } \\
\text { conditions }\end{array}$ & $\begin{array}{l}\text { Jenkins } \text { et al. } \\
\text { 2004; } \\
\text { Richard, } 2003\end{array}$ \\
\hline Tyре 0914 & $\begin{array}{l}\text { Straight or curved } \\
\text { filaments } 50 \text { to } 200 \\
\mu \mathrm{m} \text { in length; } \\
\text { Gram negative, but } \\
\text { may stain Gram } \\
\text { positive when } \\
\text { sulphide present }\end{array}$ & $\begin{array}{l}\text { Volatile fatty acid } \\
\text { substrate; Sulfide } \\
\text { substrate; }\end{array}$ & $\begin{array}{l}\text { Site-specific } \\
\text { controls }\end{array}$ & $\begin{array}{l}\text { Jenkins et al. } \\
\text { 2004; } \\
\text { Richard, } 2003\end{array}$ \\
\hline Nostocoida limicola & $\begin{array}{l}\text { Bent filaments } 40 \\
\text { to } 100 \mu \mathrm{m} \text { in } \\
\text { length; Gram } \\
\text { positive in } \\
\text { municipal } \\
\text { wastewaters } \\
\end{array}$ & $\begin{array}{l}\text { Phosphorous } \\
\text { deficiency; Simple } \\
\text { sugar substrates; } \\
\text { Volatile fatty acid } \\
\text { substrates }\end{array}$ & $\begin{array}{l}\text { Site-specific } \\
\text { controls }\end{array}$ & $\begin{array}{l}\text { Jenkins et al. } \\
2004 ; \\
\text { Richard, } \\
2003 ; \\
\text { Lemmer et } \\
\text { al., } 2000 \\
\end{array}$ \\
\hline Tyре 0411 & $\begin{array}{l}\text { Curved filaments } \\
50 \text { to } 150 \mu \mathrm{m} \text { in } \\
\text { length; Gram } \\
\text { negative }\end{array}$ & $\begin{array}{l}\text { Low SRT/High F/M; } \\
\text { Volatile fatty acid } \\
\text { substrate; }\end{array}$ & Increase SRT & $\begin{array}{l}\text { Jenkins } \text { et al. } \\
\text { 2004; } \\
\text { Richard, } 2003\end{array}$ \\
\hline
\end{tabular}




\begin{tabular}{|c|c|c|c|c|}
\hline Type 0092 & $\begin{array}{l}\text { Straight or bent } \\
\text { filaments } 10 \text { to } 80 \\
\mu \mathrm{m} \text { in length; } \\
\text { Gram negative }\end{array}$ & $\begin{array}{l}\text { Slowly degradable } \\
\text { substrates; High water } \\
\text { temp. (above } 15^{\circ} \mathrm{C} \text { ); }\end{array}$ & $\begin{array}{l}\text { Site-specific } \\
\text { controls }\end{array}$ & $\begin{array}{l}\text { Jenkins } \text { et al. } \\
2004 ; \\
\text { Lemmer et } \\
\text { al., } 2000\end{array}$ \\
\hline Type 0581 & $\begin{array}{l}\text { Curved or spiral } \\
\text { filaments } 100 \text { to } \\
200 \mu \mathrm{m} \text { in length; } \\
\text { Gram negative }\end{array}$ & High SRT/Low F/M & Decrease SRT & $\begin{array}{l}\text { Jenkins et al. } \\
\text { 2004; } \\
\text { Richard, } 2003\end{array}$ \\
\hline Type 0675 & $\begin{array}{l}\text { Straight filaments } \\
50 \text { to } 150 \mu \mathrm{m} \text { in } \\
\text { length; Gram } \\
\text { variable or Gram } \\
\text { positive }\end{array}$ & $\begin{array}{l}\text { High SRT/Low F/M; } \\
\text { Slowly degradable } \\
\text { substrates; }\end{array}$ & Decrease SRT & $\begin{array}{l}\text { Jenkins } \text { et al. } \\
\text { 2004; } \\
\text { Richard, } 2003\end{array}$ \\
\hline Type 1851 & $\begin{array}{l}\text { Straight or curved } \\
\text { filaments in } \\
\text { bundles } 50 \text { to } 200 \\
\mu \mathrm{m} \text { in length; } \\
\text { Gram variable or } \\
\text { Gram positive }\end{array}$ & $\begin{array}{l}\text { High SRT/Low F/M; } \\
\text { Simple sugar substrate; }\end{array}$ & Decrease SRT & $\begin{array}{l}\text { Jenkins } \text { et al. } \\
2004 ; \\
\text { Richard, } \\
2003 ; \\
\text { Lemmer } \text { et } \\
\text { al., } 2000\end{array}$ \\
\hline Type 0803 & $\begin{array}{l}\text { Straight filaments } \\
50 \text { to } 150 \mu \mathrm{m} \text { in } \\
\text { length; Gram } \\
\text { negative }\end{array}$ & High SRT/Low F/M; & Decrease SRT & $\begin{array}{l}\text { Jenkins et al. } \\
\text { 2004; } \\
\text { Richard, } 2003\end{array}$ \\
\hline Type 1863 & $\begin{array}{l}\text { Bent or curved } \\
\text { filaments } 10 \text { to } 50 \\
\mu \mathrm{m} \text { in length; } \\
\text { Gram negative }\end{array}$ & $\begin{array}{l}\text { Low SRT/High F/M; } \\
\text { Hydrophobic substrates }\end{array}$ & Increase SRT & $\begin{array}{l}\text { Jenkins et al. } \\
\text { 2004; } \\
\text { Richard, } 2003\end{array}$ \\
\hline Fungi & $\begin{array}{l}\text { Filaments with true } \\
\text { branching } \\
\text { morphology } 100 \text { to } \\
1000 \mu \mathrm{m} \text { in length; } \\
\text { Gram positive }\end{array}$ & $\begin{array}{l}\text { Low pH }(<6) ; \\
\text { Septicity; May be } \\
\text { imported from outside } \\
\text { the WWTP. }\end{array}$ & $\begin{array}{l}\text { Increase } \mathrm{pH} ; \\
\text { Remove septicity }\end{array}$ & $\begin{array}{l}\text { Jenkins et al. } \\
2004 ; \\
\text { Richard, } \\
2003 ; \\
\text { Kappeler and } \\
\text { Gujer, } 1994\end{array}$ \\
\hline
\end{tabular}

Table A1.2 - Ranking of Filament Abundance in Microscopic Evaluation

\begin{tabular}{|l|l|l|}
\hline Numerical Value & Descriptor & Filament \\
\hline 0 & None & None observed \\
\hline 1 & Few & Only observed in some flocs \\
\hline 2 & Some & Observed in most but not all flocs \\
\hline 3 & Common & 1 to 5 filaments observed per floc \\
\hline 4 & Very Common & 5 to 20 filaments observed per floc \\
\hline 5 & Abundant & $>20$ filaments per floc \\
\hline 6 & Excessive & $\begin{array}{l}\text { Filaments more abundant than flocs, and observed in bulk } \\
\text { solution }\end{array}$ \\
\hline
\end{tabular}




\section{Appendix 2 - Calculations}

This appendix lists and explains the calculations used to develop parameters that were subject to analysis in this study. The parameters discussed here and in the Results section (section 4) are outlined below in Table A2.1. The equations used to derive the parameters are listed below.

Table A2.1 - List of Derived Parameters

\begin{tabular}{|l|l|l|}
\hline Equation & Term & Description \\
\hline 1 & ORP $(\mathrm{mV})$ & $\begin{array}{l}\text { ORP is a measure of the oxidation-reduction potential } \\
\text { of a solution. It measures the ability of a solution to } \\
\text { gain or lose electrons, and thus ORP measures the } \\
\text { transferability of charge of a solution. }\end{array}$ \\
\hline 2 & Total Solids (\%) & $\begin{array}{l}\text { The total solids test measures the percentage of dry } \\
\text { solids within a sample. }\end{array}$ \\
\hline 3 & Total Suspended Solids $(\mathrm{mg} / \mathrm{L})$ & $\begin{array}{l}\text { Total suspended solids tests measure the mass of dried } \\
\text { solids that are removed from a liquid sample after } \\
\text { vacuum filtration through } 1.5 \mu \mathrm{m} \text { aperture size filter } \\
\text { paper }\end{array}$ \\
\hline 4 & Total Volatile Solids (\%) & $\begin{array}{l}\text { The total volatile solids test measures the percentage of } \\
\text { mass of dried solids that is volatized at } 550^{\circ} \mathrm{C} .\end{array}$ \\
\hline 5 & Solid Retention Time (d) & $\begin{array}{l}\text { The SRT measures the amount of time that activated } \\
\text { sludge is retained in the aeration system. }\end{array}$ \\
\hline
\end{tabular}

1.) The calculation used to determine the oxidation-reduction potential of polymer solutions is shown in equation [1]:

$$
E_{\text {system }}=E_{\text {observed }}+E_{\text {reference }}-E_{\text {reference(observed) }}
$$

Where: $\quad E_{\text {system }}$ is the oxidation-reduction potential of the solution (mV)

$E_{\text {observed }}$ is the oxidation-reduction potential measured by the ORP probe $(\mathrm{mV})$ 
$E_{\text {reference }}$ is the true oxidation-reduction potential of the reference solution $(\mathrm{mV})$

$E_{\text {reference (observed) }}$ is the measured oxidation-reduction potential of the reference solution $(\mathrm{mV})$

The reference solution used for this procedure is $1.00 \mathrm{M} \mathrm{KCL}$ standard redox solution. It provides a benchmark by which the ORP of the polymer solution is adjusted so that fluctuations in the sensitivity of the electrode may be accounted for.

2.) The calculation used to determine the total solids percentage of a sample is shown in equation [2]:

$$
T S=\frac{M_{D S}}{M_{S}} \times 100
$$

Where: $\quad$ TS is the total solids percentage of the sample (\%)

$\mathrm{M}_{\mathrm{DS}}$ is the mass of sample after dying $(\mathrm{g})$

$\mathrm{M}_{\mathrm{S}}$ is the mass of sample before drying (g)

3.) The calculation used to determine the total suspended solids concentration of a sample is shown in equation [3]:

$$
S S=\frac{M_{P S}-M_{P}}{V_{S}} \times 1000
$$

Where: $\quad$ SS is the concentration of suspended solids in the sample $(\mathrm{mg} / \mathrm{L})$ 
$M_{P S}$ is the mass of paper after sample filtration and drying $(\mathrm{g})$

$\mathrm{M}_{\mathrm{P}}$ is the mass of paper before sample filtration (g)

$\mathrm{V}_{\mathrm{S}}$ is the volume of sample $(\mathrm{mL})$

4.) The calculation used to determine the percentage mass of total volatile solids is shown in equation [4]:

$V S=\frac{M_{D S}-M_{V S}}{M_{D S}} \times 100$

Where: $\quad$ VS is the percentage of dried solids in the sample that are volatile (\%)

$\mathrm{M}_{\mathrm{DS}}$ is the mass of sample after drying ( $\mathrm{g}$ )

Mvs is the mass of sample after burning at $550^{\circ} \mathrm{C}$

5.) The calculation used to determine the solid retention time is shown in equation (5):

$$
S R T=\frac{V_{a} X_{a}}{Q_{w} X_{w}+Q_{e} X_{e}}
$$

Where: $\quad$ SRT is the solid retention time (d)

$\mathrm{V}_{\mathrm{a}}$ is the volume of the aeration reactor(s) $\left(\mathrm{m}^{3}\right)$

$X_{a}$ is the concentration of suspended solids in activated sludge within the aeration reactor $\left(\mathrm{g} / \mathrm{m}^{3}\right)$

$Q_{w}$ is the flow of WAS out of the activated sludge system $\left(\mathrm{m}^{3} / \mathrm{d}\right)$

$X_{w}$ is the concentration of suspended solids in WAS $\left(\mathrm{g} / \mathrm{m}^{3}\right)$

$Q_{e}$ is the flow of liquid effluent out of the WWTP $\left(\mathrm{m}^{3} / \mathrm{d}\right)$ 
$\mathrm{X}_{\mathrm{w}}$ is the concentration of suspended solids in of liquid effluent out of the WWTP $\left(\mathrm{g} / \mathrm{m}^{3}\right)$ 


\section{Appendix 3 - Foaming Spray System}

In this appendix, the trial of a spray system used to combat foaming is presented. The reason that a spray system was identified as a potential solution for combating the foaming problem is that foam-trapping has been shown to exacerbate foaming problems in secondary clarifiers. According to Jenkins et al. (2004), and Cha et al. (1992), foam trapping can cause the volume of filamentous bacteria foam to increase greatly. At Crystal Beach WWTP, the secondary clarifier inlets (shown in Figure A3.1), were identified as an area where foam trapping occurred continuously.

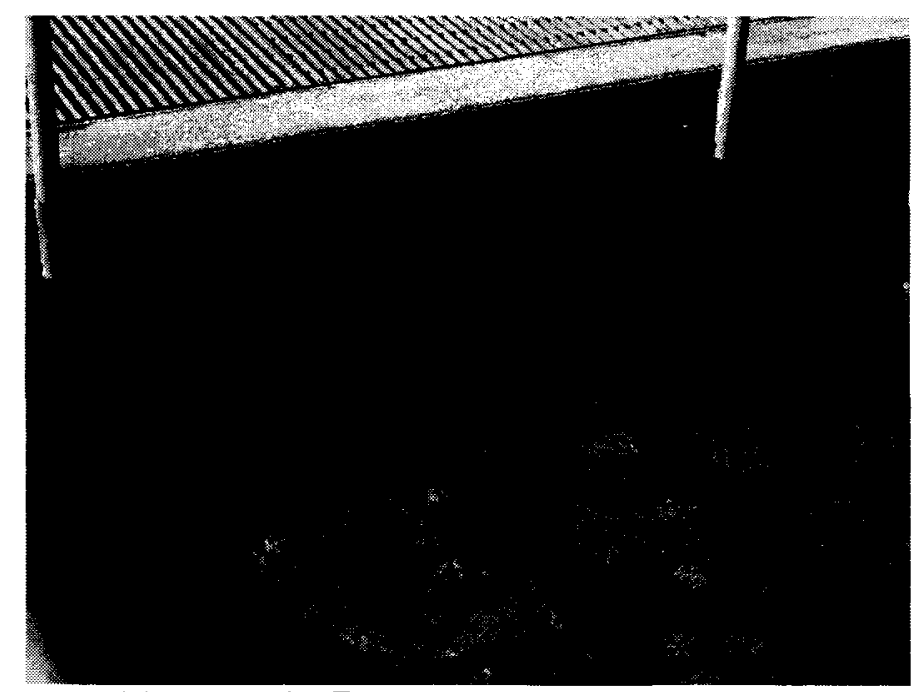

Figure A3.1 - Foam Trapping at Clarifier Inlet

Therefore, a chlorine spray system was designed to test the effectiveness of water or chlorinated water used to contact the foam and cause the foam to subside. Figure A3.2 shows a photograph of the spray system. The system was ineffective at eradicating all of the observed foam from the trial clarifier. This was due to the fact that the range of the spray was not large enough to target the entire surface of the foam. Thus, a permanent 
spray system will need to be capable of targeting the entire surface of the clarifier inlet area, in order to be effective at reducing foam trapping. To do so economically, a more powerful effluent water pump would be useful so that plant effluent may be used, as opposed to municipally treated potable water.

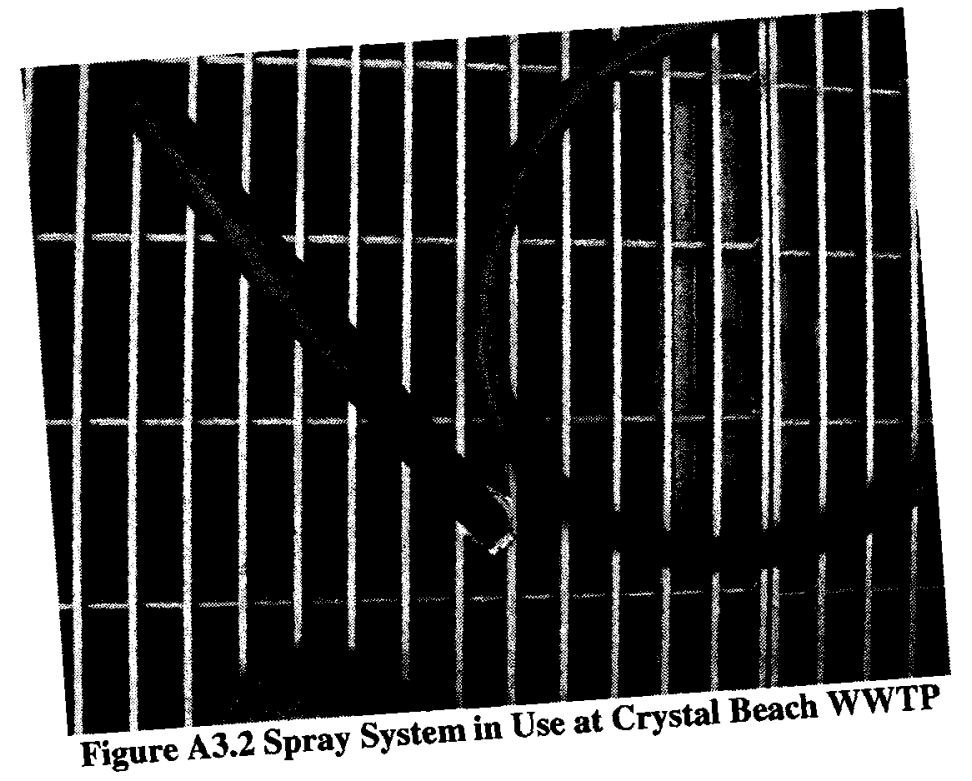




\section{Appendix 4-Polymer Characteristics}

This appendix presents the chemical characteristics of the polymers that were tested in this study. The charge density refers to the percentage of the polymer chain that exhibits a positive charge. This percentage may be very low (less than 10 percent), low (10 to 30 percent), medium (30 to 50 percent), high (50 to 70 percent), or very high (over 70 percent. The molecular weight refers to the average mass in grams of one mole of polymer molecules. Among the polymers tested in this study, the molecular weight may be medium (between approximately $10^{5}$ and $10^{6} \mathrm{~g} / \mathrm{mol}$ ), medium-high (approximately $10^{6} \mathrm{~g} / \mathrm{mol}$ ), high (between approximately $10^{6}$ and $10^{7} \mathrm{~g} / \mathrm{mol}$ ), or very high (over $10^{7}$ $\mathrm{g} / \mathrm{mol})$.

Table A4.1 - Polymer Characteristics

\begin{tabular}{|c|c|c|c|c|}
\hline Supplier & Polymer Name & Charge Density & Molecular Weight & Comments \\
\hline $\begin{array}{l}\text { Investment } \\
\text { Recovery } \\
\text { Group }\end{array}$ & CB 4450 & Medium & High & $\begin{array}{l}\text { Incumbent Polymer } \\
\text { at Crystal Beach } \\
\text { WWTP }\end{array}$ \\
\hline \multirow[t]{4}{*}{$\begin{array}{l}\text { CIBA } \\
\text { Chemical }\end{array}$} & 7557 & Medium & Medium & $\begin{array}{l}\text { Used for bench- } \\
\text { scale testing }\end{array}$ \\
\hline & 7587 & High & Medium & \\
\hline & 8180 & High & Medium - High & \\
\hline & 8160 & Medium & Medium - High & $\begin{array}{l}\text { Used for bench- } \\
\text { scale testing }\end{array}$ \\
\hline \multirow[t]{3}{*}{ Jes-Chem } & 49 & Low & High & $\begin{array}{l}\text { Used for bench- } \\
\text { scale testing }\end{array}$ \\
\hline & 60 & Medium & High & \\
\hline & 473 & High & High & $\begin{array}{l}\text { Used for bench- } \\
\text { scale testing }\end{array}$ \\
\hline \multirow[t]{8}{*}{ SNF Chemical } & 4550 & High & High & \\
\hline & 4140 & Very low & Medium - High & \\
\hline & 4190 & Low & High & $\begin{array}{l}\text { Used for bench- } \\
\text { scale testing }\end{array}$ \\
\hline & 4240 & Low & High & \\
\hline & 4210 & Low & Very High & \\
\hline & 4290 & Low & High & $\begin{array}{l}\text { Used for bench- } \\
\text { scale and full-scale } \\
\text { testing }\end{array}$ \\
\hline & 4700 & High & Medium - High & \\
\hline & 4800 & Very High & Medium - High & \\
\hline
\end{tabular}




\begin{tabular}{|l|l|l|l|l|}
\hline \multirow{3}{*}{$\begin{array}{l}\text { Epsilon } \\
\text { Chemical }\end{array}$} & 483 & Medium & High & \\
\cline { 2 - 5 } & 4800 & Medium & High & \\
\cline { 2 - 5 } & 4900 & High & Very High & \\
\cline { 2 - 6 } & 4925 & High & Very High & $\begin{array}{l}\text { Used for bench- } \\
\text { scale and full-scale } \\
\text { testing }\end{array}$ \\
\hline
\end{tabular}




\section{Appendix 5 - T test for Paired Datasets}

In this Appendix, the full-scale polymer data is examined with a Student's t test to determine the reproducibility of data from week one testing to week two testing. $\mathrm{T}$ statistics from two different confidence intervals are listed, a 95 percent confidence interval and a 99 percent confidence interval. If the calculated $t$ value ( $t$ calculated) is less than $\mathrm{t}$ statistic corresponding to a given confidence interval ( $\mathrm{t}$ critical), then it is assumed that the data sets came from the same data population, and thus combining the data from the two different data sets (i.e. week 1 and week 2), is statistically justifiable. For the purpose of this study, the 99 percent confidence interval was selected as the critical $t$ value. The sample calculation below uses the following two equations [5] and [6] to calculate the t statistic:

$$
S_{c}^{2}=\frac{\left(N_{a} \times{s_{a}}^{2}\right)+\left(N_{b} \times s_{b}{ }^{2}\right)}{N_{a}+N_{b}}
$$

Where: $\quad S_{c}$ is the pooled estimate of variance between dataset $a$ and dataset $b$ $\mathrm{N}_{\mathrm{a}}$ is the number of samples in dataset a $\mathrm{s}_{\mathrm{a}}{ }^{2}$ is the standard deviation of dataset a $\mathrm{N}_{\mathrm{b}}$ is the number of samples in dataset $b$ $\mathrm{s}_{\mathbf{b}}{ }^{2}$ is the standard deviation of dataset $\mathrm{b}$ 


$$
t=\frac{\left|X_{a}-X_{B}\right|}{S_{C} \times \sqrt{\frac{N_{a}+N_{b}}{N_{a} \times N_{b}}}}
$$

Where: $\quad t$ is the $t$ statistic

$$
\begin{aligned}
& X_{a} \text { is the mean of dataset } a \\
& X_{b} \text { is the mean of dataset } b \\
& S_{c} \text { is the pooled estimate of variance between dataset a and dataset } b \\
& N_{a} \text { is the number of samples in dataset } a \\
& N_{b} \text { is the number of samples in dataset } b
\end{aligned}
$$

Sample Calculation:

\begin{tabular}{l|r|r|r|} 
Polymer & Dose & Set 1 & \multicolumn{1}{l|}{ Set 2 } \\
\hline $\mathrm{CB}$ & 2.75 & 1.50411 & 1.7665751 \\
& & 1.60814 & 1.6486758 \\
& & 1.78607 & 1.856255 \\
\hline average & & 1.63277 & 1.7571687 \\
stdev & & 0.14258 & 0.1041088 \\
samples & & 3 & 3
\end{tabular}

pooled estimate of variance AverageX1-AverageX2 Sc*sample numbers calculate $T$ value Degrees of Freedom T critical (.05 2 tailed) Since $\mathrm{T}<\mathrm{Tcrit}$ we conclude that the averages are not different

The results of the $t$ test are summarized in Table A5.1. Where values are in grey boxes, the calculated $t$ value exceeds the critical $t$ value for a 99 percent confidence interval, and so the datasets are from different populations. In other words, for those parameters corresponding to a $t$ value greater than the critical $t$ value, the data was not reproducible from week 1 to week 2 for a given parameter and polymer. 
Table A5.1 - Summary of Paired T Test Results

\begin{tabular}{|c|c|c|c|c|c|}
\hline \multicolumn{6}{|c|}{ T Test Summary - Thickened Sludge } \\
\hline Parameter & Polymer & $\begin{array}{l}\text { Dose (g dry polymer/kg } \\
\text { sludge solids) }\end{array}$ & $\begin{array}{l}\text { T critical } \\
(.95)\end{array}$ & $\begin{array}{l}\text { T Critical } \\
(.99)\end{array}$ & $\begin{array}{l}\mathbf{T} \\
\text { Calculated } \\
\end{array}$ \\
\hline \multirow{17}{*}{$\%$ Solid } & CB4450 & 2.75 & 2.78 & 4.60 & 0.33 \\
\hline & & 3.65 & 2.78 & 4.60 & 2.42 \\
\hline & & 4.55 & 2.78 & 4.60 & 1.11 \\
\hline & & 5.45 & 2.78 & 4.60 & 0.29 \\
\hline & & 6.35 & 2.78 & 4.60 & 0.43 \\
\hline & & 7.25 & 2.78 & 4.60 & 0.94 \\
\hline & SNF4290 & 1.85 & 2.78 & 4.60 & 0.03 \\
\hline & & 2.75 & 2.78 & 4.60 & 1.41 \\
\hline & & 3.65 & 2.78 & 4.60 & 1.01 \\
\hline & & 4.55 & 2.78 & 4.60 & 3.13 \\
\hline & & 5.45 & 2.78 & 4.60 & 2.37 \\
\hline & & 6.35 & 2.78 & 4.60 & 1.15 \\
\hline & EC4925 & 2.75 & 2.78 & 4.60 & 2.80 \\
\hline & & 3.65 & 2.78 & 4.60 & 2.61 \\
\hline & & 4.55 & 2.78 & 4.60 & 2.10 \\
\hline & & 5.45 & 2.78 & 4.60 & 0.64 \\
\hline & & 6.35 & 2.78 & 4.60 & 3.06 \\
\hline \multirow[t]{17}{*}{$\begin{array}{c}\text { Total } \\
\text { Phosphorous } \\
\end{array}$} & CB4450 & 2.75 & 2.78 & 4.60 & 6 \\
\hline & & 3.65 & 2.78 & 4.60 & 1.54 \\
\hline & & 4.55 & 2.78 & 4.60 & 3.46 \\
\hline & & 5.45 & 2.78 & 4.60 & 3.95 \\
\hline & & 6.35 & 2.78 & 4.60 & 0.66 \\
\hline & & 7.25 & 2.78 & 4.60 & 0.35 \\
\hline & SNF4290 & 1.85 & 2.78 & 4.60 & 4.14 \\
\hline & & 2.75 & 2.78 & 4.60 & 2.74 \\
\hline & & 3.65 & 2.78 & 4.60 & 0.58 \\
\hline & & 4.55 & 2.78 & 4.60 & 0.23 \\
\hline & & 5.45 & 2.78 & 4.60 & 4.38 \\
\hline & & 6.35 & 2.78 & 4.60 & 2.85 \\
\hline & EC4925 & 2.75 & 2.78 & 4.60 & 6364 \\
\hline & & 3.65 & 2.78 & 4.60 & 26 \\
\hline & & 4.55 & 2.78 & 4.60 & $904^{2}$ \\
\hline & & 5.45 & 2.78 & 4.60 & 4.33 \\
\hline & & 6.35 & 2.78 & 4.60 & 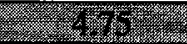 \\
\hline \multirow[t]{8}{*}{ TKN } & CB4450 & 2.75 & 2.78 & 4.60 & 0.84 \\
\hline & & 3.65 & 2.78 & 4.60 & 2.20 \\
\hline & & 4.55 & 2.78 & 4.60 & 2.45 \\
\hline & & 5.45 & 2.78 & 4.60 & 0.96 \\
\hline & & 6.35 & 2.78 & 4.60 & 4.72 \\
\hline & & 7.25 & 2.78 & 4.60 & 2.30 \\
\hline & SNF4290 & 1.85 & 2.78 & 4.60 & 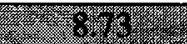 \\
\hline & & 2.75 & 2.78 & 4.60 & 3.65 \\
\hline
\end{tabular}




\begin{tabular}{|c|c|c|c|c|c|}
\hline & & 3.65 & 2.78 & 4.60 & 2.82 \\
\hline & & 4.55 & 2.78 & 4.60 & 0.90 \\
\hline & & 5.45 & 2.78 & 4.60 & 3.31 \\
\hline & & 6.35 & 2.78 & 4.60 & 2.24 \\
\hline & EC4925 & 2.75 & 2.78 & 4.60 & 68.41 \\
\hline & & 3.65 & 2.78 & 4.60 & 4.22 \\
\hline & & 4.55 & 2.78 & 4.60 & 24.85 \\
\hline & & 5.45 & 2.78 & 4.60 & $3.4: 9 5 \longdiv { 1 }$ \\
\hline & & 6.35 & 2.78 & 4.60 & 2.51 \\
\hline \multicolumn{6}{|c|}{ T Test Summary - Filtrate } \\
\hline Parameter & Polymer & $\begin{array}{c}\text { Dose (g dry polymer/kg } \\
\text { sludge solids) }\end{array}$ & $\begin{array}{c}\text { T critical } \\
(.95)\end{array}$ & $\begin{array}{c}\text { T Critical } \\
(.99)\end{array}$ & $\begin{array}{c}\mathbf{T} \\
\text { Calculated } \\
\end{array}$ \\
\hline \multirow[t]{17}{*}{$\%$ Solid } & CB4450 & 2.75 & 2.78 & 4.60 & 1.41 \\
\hline & & 3.65 & 2.78 & 4.60 & 0.15 \\
\hline & & 4.55 & 2.78 & 4.60 & 0.03 \\
\hline & & 5.45 & 2.78 & 4.60 & 0.33 \\
\hline & & 6.35 & 2.78 & 4.60 & 0.12 \\
\hline & & 7.25 & 2.78 & 4.60 & 0.06 \\
\hline & SNF4290 & 1.85 & 2.78 & 4.60 & 1.51 \\
\hline & & 2.75 & 2.78 & 4.60 & 0.61 \\
\hline & & 3.65 & 2.78 & 4.60 & 0.07 \\
\hline & & 4.55 & 2.78 & 4.60 & 0.25 \\
\hline & & 5.45 & 2.78 & 4.60 & 0.30 \\
\hline & & 6.35 & 2.78 & 4.60 & 0.15 \\
\hline & EC4925 & 2.75 & 2.78 & 4.60 & 0.49 \\
\hline & & 3.65 & 2.78 & 4.60 & 0.24 \\
\hline & & 4.55 & 2.78 & 4.60 & 0.31 \\
\hline & & 5.45 & 2.78 & 4.60 & 0.01 \\
\hline & & 6.35 & 2.78 & 4.60 & 0.23 \\
\hline \multirow[t]{17}{*}{ SS } & CB4450 & 2.75 & 2.78 & 4.60 & 12.21 \\
\hline & & 3.65 & 2.78 & 4.60 & 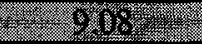 \\
\hline & & 4.55 & 2.78 & 4.60 & 3.32 \\
\hline & & 5.45 & 2.78 & 4.60 & 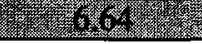 \\
\hline & & 6.35 & 2.78 & 4.60 & 0.54 \\
\hline & & 7.25 & 2.78 & 4.60 & 7.89 \\
\hline & SNF4290 & 1.85 & 2.78 & 4.60 & 2.39 \\
\hline & & 2.75 & 2.78 & 4.60 & s. \\
\hline & & 3.65 & 2.78 & 4.60 & 1.14 \\
\hline & & 4.55 & 2.78 & 4.60 & 1423 \\
\hline & & 5.45 & 2.78 & 4.60 & 0.58 \\
\hline & & 6.35 & 2.78 & 4.60 & 2.48 \\
\hline & EC4925 & 2.75 & 2.78 & 4.60 & 1.04 \\
\hline & & 3.65 & 2.78 & 4.60 & 802 \\
\hline & & 4.55 & 2.78 & 4.60 & 69.12 \\
\hline & & 5.45 & 2.78 & 4.60 & 1.94 \\
\hline & & 6.35 & 2.78 & 4.60 & 0.60 \\
\hline \multirow[t]{7}{*}{$\begin{array}{c}\text { Total } \\
\text { Phosphorous } \\
\end{array}$} & CB4450 & 2.75 & 2.78 & 4.60 & 0.97 \\
\hline & & 3.65 & 2.78 & 4.60 & 2.70 \\
\hline & & 4.55 & 2.78 & 4.60 & 1.69 \\
\hline & & 5.45 & 2.78 & 4.60 & 2.45 \\
\hline & & 6.35 & 2.78 & 4.60 & 0.92 \\
\hline & & 7.25 & 2.78 & 4.60 & 1.48 \\
\hline & SNF4290 & 1.85 & 2.78 & 4.60 & N/A \\
\hline
\end{tabular}




\begin{tabular}{|l|l|l|l|l|l|}
\hline & & 2.75 & 2.78 & 4.60 & 6.93 \\
\hline & & 3.65 & 2.78 & 4.60 & 0.67 \\
\hline & & 4.55 & 2.78 & 4.60 & 3.22 \\
\hline & & 5.45 & 2.78 & 4.60 & 1.54 \\
\hline & & 6.35 & 2.78 & 4.60 & 0.09 \\
\hline & EC4925 & 2.75 & 2.78 & 4.60 & 0.27 \\
\hline & & 3.65 & 2.78 & 4.60 & 0.54 \\
\hline & & 4.55 & 2.78 & 4.60 & 0.54 \\
\hline & & 5.45 & 2.78 & 4.60 & 0.45 \\
\hline & & 6.35 & 2.78 & 4.60 & 1.20 \\
\hline Ammonia & CB4450 & 2.75 & 2.78 & 4.60 & N/A \\
\hline & & 3.65 & 2.78 & 4.60 & 3.77 \\
\hline & & 4.55 & 2.78 & 4.60 & 3.11 \\
\hline & & 5.45 & 2.78 & 4.60 & 2.88 \\
\hline & & 6.35 & 2.78 & 4.60 & 0.02 \\
\hline & & 7.25 & 2.78 & 4.60 & 0.23 \\
\hline & SNF4290 & 1.85 & 2.78 & 4.60 & N/A \\
\hline & & 2.75 & 2.78 & 4.60 & 1.41 \\
\hline & & 3.65 & 2.78 & 4.60 & 0.04 \\
\hline & & 4.55 & 2.78 & 4.60 & 0.09 \\
\hline & & 5.45 & 2.78 & 4.60 & 0.24 \\
\hline & & 6.35 & 2.78 & 4.60 & 0.04 \\
\hline & EC4925 & 2.75 & 2.78 & 4.60 & 1.37 \\
\hline & & 3.65 & 2.78 & 4.60 & 0.02 \\
\hline & & 4.55 & 2.78 & 4.60 & 0.53 \\
\hline & & 5.45 & 2.78 & 4.60 & 0.04 \\
\hline & & 6.35 & 2.78 & 4.60 & 0.18 \\
\hline
\end{tabular}




\section{Appendix 6 - Polymer Selection Using Standard Scores}

In this appendix, an alternate method of selecting polymers for full-scale testing is presented. During bench-scale polymer testing, it became necessary to develop a decision-making methodology for selecting polymers for full-scale trials, as the polymers were evaluated at bench-scale with respect to a wide variety of parameters. The parameters listed in Table 3.1 were weighted according to a prioritization of polymer performance. The values obtained in the testing were then converted to z-scores, (i.e. normalized). By multiplying the z-score for each polymer in each test by the relative weight of that parameter, and adding those figures together for each polymer, the relative performance of each polymer can be evaluated. Furthermore, polymer performance with respect to both the thickened solids produced and the filtrate could be combined into one value. In this case, the data from all polymers for a given parameter is averaged, and the standard deviation is computed. Then, the value for any one parameter may be converted to a z-score using the following formula:

$z=\frac{x-\mu}{\sigma}$

Where: $\quad z$ is the value of the standardized $z$-score, in units of standard deviation

$\mathrm{X}$ is the value of the raw data point

$\mu$ is the sample mean of the raw data

$\sigma$ is the sample standard deviation of the raw data 
In practice, the relative weights of the parameters may be varied to reflect different priorities, and the best polymer with respect to a given weighting scheme may be determined. For example, the weighting scheme shown in Table A6.1 may be used. In this example, each parameter is weighted separately, and the weights for each the solid phase and the liquid phase add up to one. Because it is desirable to have thickened sludge relatively high in the parameters listed below and filtrate relatively low in the parameters listed below, it is necessary to multiply the z-scores generated from the filtrate data by negative one before adding them together. To combine the results from solid phase and liquid phase testing, each total is weighted and added together. In this case, the solid phase data is given double the weight of the liquid phase data. Once the data is added up, the resulting scores represent a weighted average of the z-scores for the combined dataset. These averages may be above or below zero, so for analysis purposes, an arbitrary value may be added to all values, in order to make all numbers positive.

Table A6.1 - Hypothetical Weighting Scheme for Polymer Selection

\begin{tabular}{|l|l|c|c|}
\hline Phase & Parameter & Parameter Weight & Phase Weight \\
\hline Thickened Sludge & Total Solids & 0.4 & \\
\hline & Total Volatile Solids & 0.1 & \\
\hline & TKN & 0.2 & \\
\hline & Total Phosphorus & 0.2 & \\
\hline & Total BOD & 0.1 & 0.67 \\
\hline Filtrate & TOTAL & 1.0 & \\
\hline & Total Solids & 0.1 & \\
\hline & Turbidity & 0.1 & \\
\hline & TKN & 0.2 & \\
\hline & Ammonia & 0.3 & 0.33 \\
\hline & Total Phosphorous & 0.3 & \\
\hline & TOTAL & 1.0 & \\
\hline
\end{tabular}


Using the weighting scheme presented in Table A6.1 to analyze the actual bench-scale polymer data, the data in Table A6.2 are generated. These data represent combined weighted averages of the standardized z-scores, with an arbitrary value of 2 added to make all numbers positive. Because negative signs have been removed, higher numbers represent desirable polymer performance.

Table A6.2 - Summary of Combined Z-scores from Bench Scale Polymer Testing

\begin{tabular}{|l|c|c|c|}
\hline Polymer & Thickened Sludge & Filtrate & Total \\
\hline CB 4450 & 2.22 & 0.63 & 1.69 \\
\hline CIBA 7557 & 2.24 & 1.15 & 1.88 \\
\hline SNF 4140 & 2.01 & 1.37 & 1.80 \\
\hline SNF 4290 & 2.07 & 1.58 & 1.90 \\
\hline CIBA 8160 & 1.96 & 2.28 & 2.07 \\
\hline EC 4925 & 2.30 & 2.24 & 2.28 \\
\hline JC 49 & 2.82 & 2.17 & 2.60 \\
\hline JC 473 & 2.52 & 2.23 & 2.42 \\
\hline
\end{tabular}

In this example, polymers JC 49 and JC 473 appear to be the most desirable polymers, while polymer CB 4450 is the least desirable. Ultimately, this weighting scheme would lead one to make a poor choice of polymer for the thickening application at Crystal Beach WWTP. Polymers JC 49 and JC 473 produced thickened sludge with a total solids content of less than 2 percent. This method of polymer selection proved less effective than the simpler approach described in Section 4.1.4. 


\section{Appendix 7 - Comparison of Bench Scale and Full Scale}

\section{Polymer Testing}

In this section, the polymer testing results from bench scale testing are compared to results from full scale testing. Although full scale testing was performed over a range of dosages of polymer and bench scale was performed at only one dose, a dosage of 4.5 grams of dry polymer per kilogram sludge solids was used during both phases. Figures A7.1 to A7.6 show the results.

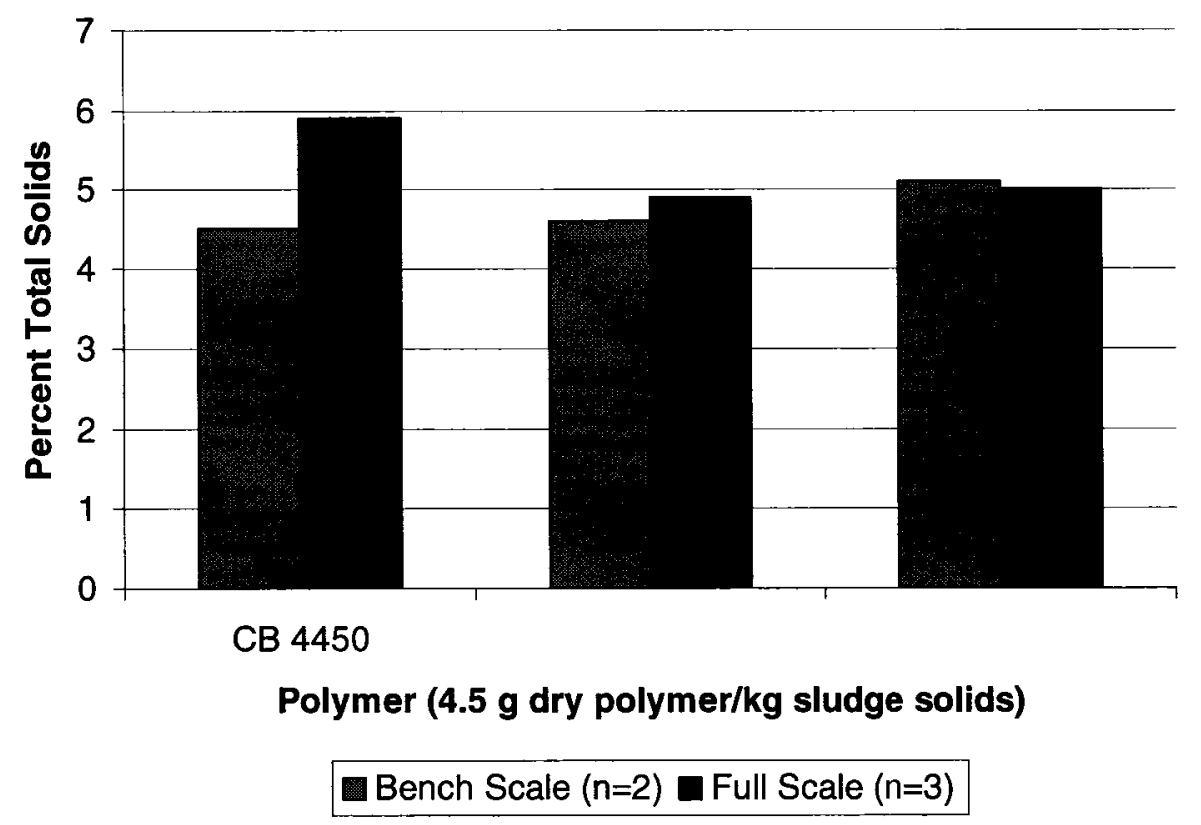

Figure A7.1- Thickened Sludge Percent Total Solids 


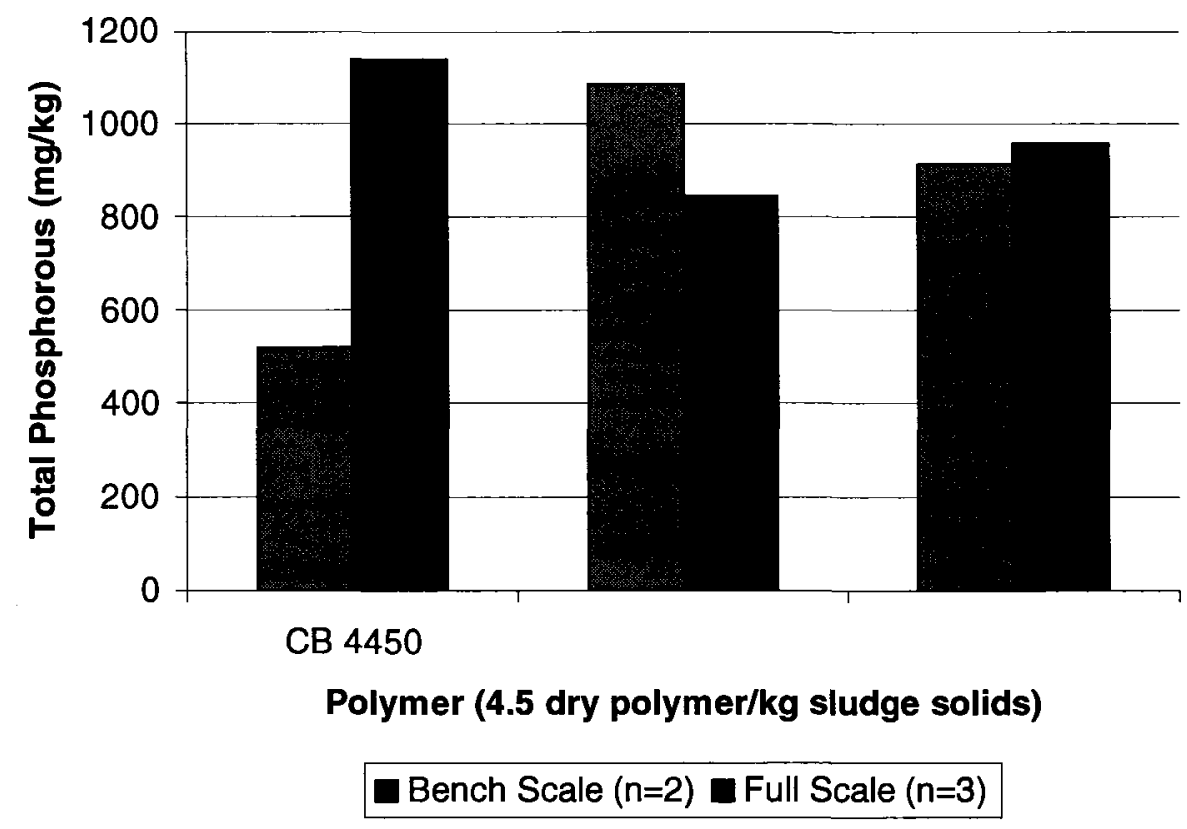

Figure A7.2 - Total Phosphorous Content of Thickened Sludge

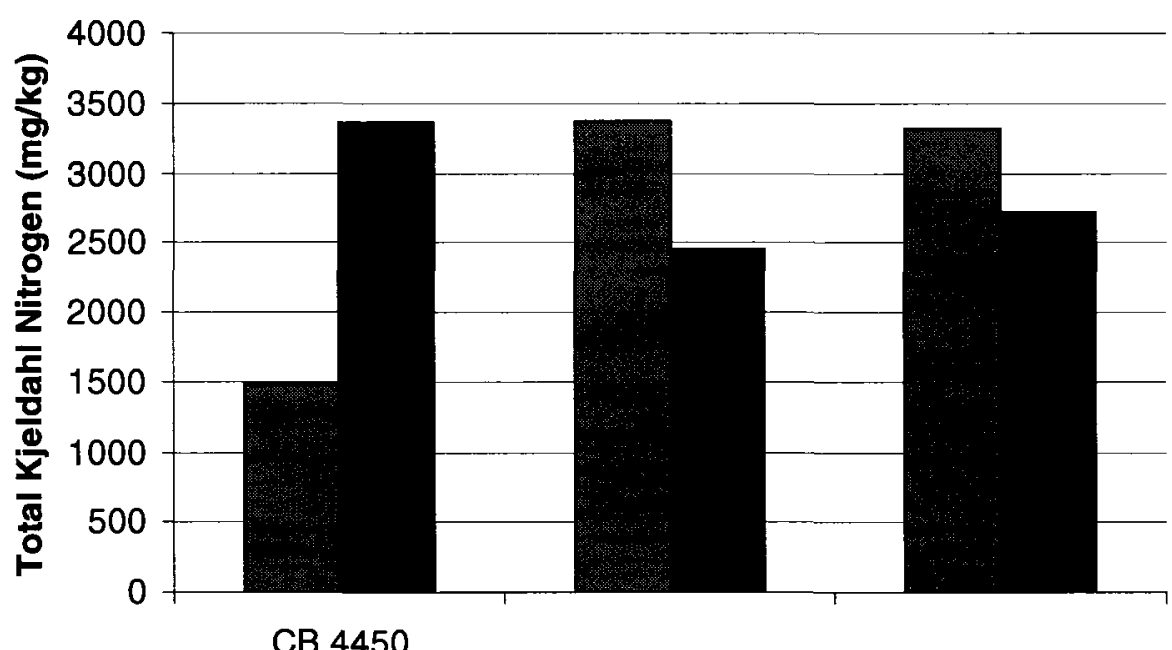

Polymer (4.5 g polymer/kg sludge solids)

Bench Scale $(n=2)$ Full Scale $(n=3)$

Figure A7.3 - TKN Content of Thickened Sludge 
Figures A7.1, A7.2 and A7.3 show the percent total solids, total phosphorous content, and TKN content of thickened sludge. The total solids data reveal that the bench scale testing allowed accurate prediction of full scale results for the two trial polymers (SNF 4290 and EC 4925), as in both cases, bench scale percent solids data are no more than one quarter of a percentage point different than the full scale percent solids data. In the case of the incumbent polymer (CB 4450), the results are about one and a half percentage points apart. In the case of the incumbent polymer, bench scale testing underestimated the percent total solids achieved at full-scale.

The total phosphorous content of thickened sludge that was measured at bench scale was a relatively good predictor of the levels found at full-scale for polymer EC 4925, (within approximately 5 percent). For the other polymers, the correlation is much weaker. Sludge thickened using polymer SNF 4290 was about 20 percent higher in total phosphorous at bench scale than at full scale. Sludge thickened using polymer CB 4450 was about 60 percent lower in total phosphorous at bench scale than at full scale. The TKN data show that for both SNF 4290 and EC 4925, thickened sludge was about 25 percent higher in TKN at bench scale than at full scale. 


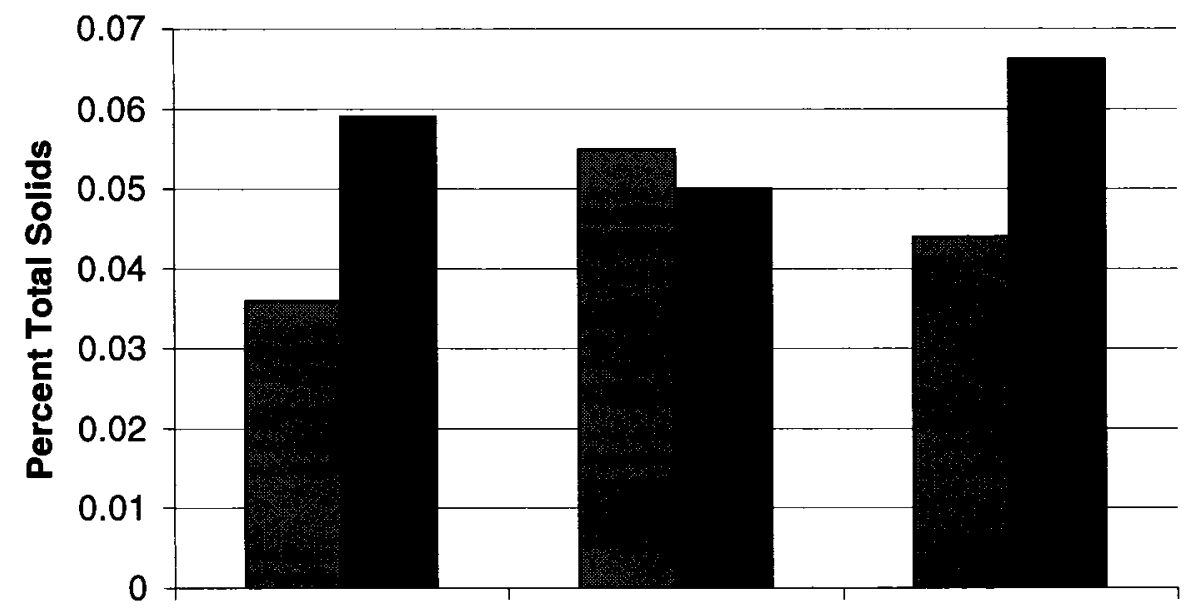

CB 4450

Polymer (4.5 g polymer/kg sludge solids)

Bench Scale $(n=2)$ Full Scale $(n=3)$

Figure A7.4 - Filtrate Percent Total Solids

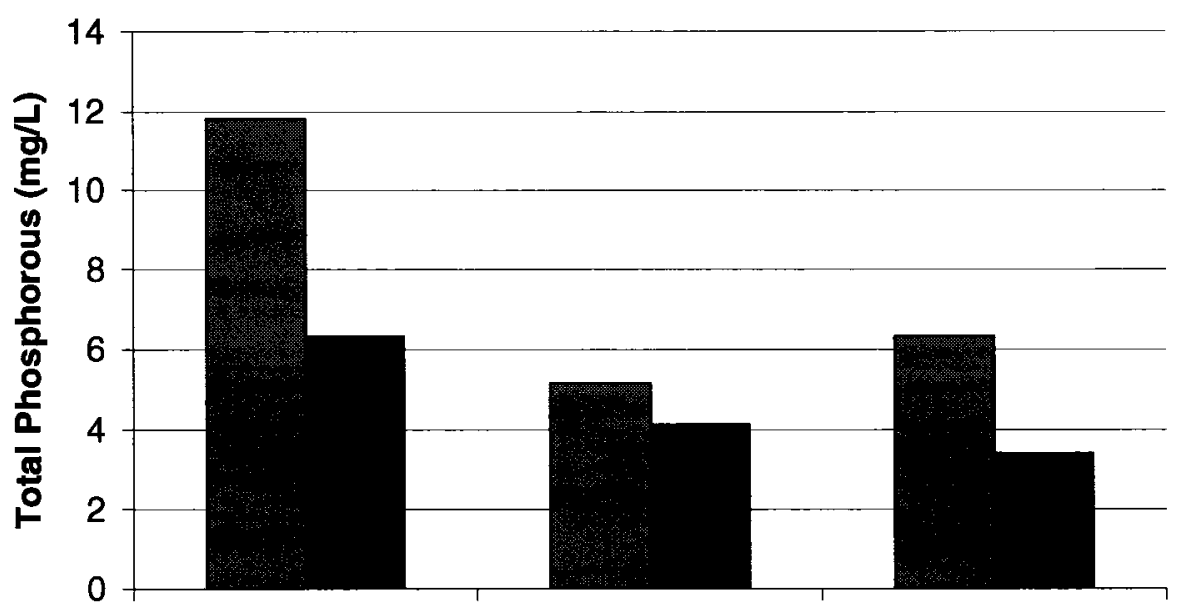

CB 4450

Polymer (4.5 g polymer/kg sludge solids)

⿴囗十 Bench Scale $\square$ Full Scale

Figure A7.5 - Filtrate Total Phosphorous Concentration 


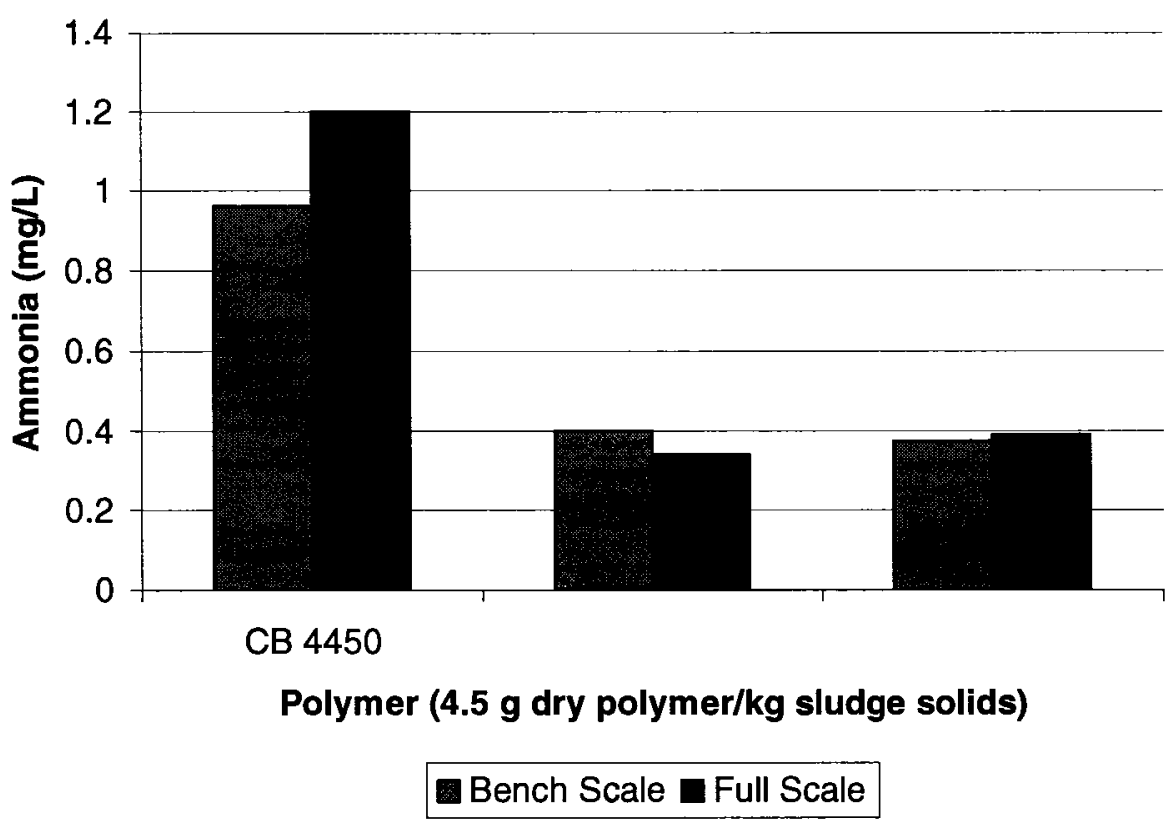

Figure A7.6 - Filtrate Ammonia Concentration

Figures A7.4, A7.5 and A7.6 show the percent total solids, total phosphorous content, and ammonia content of filtrate. The total solids data reveal that the bench scale testing allowed accurate prediction of full-scale results for the trial polymer SNF 4290, (the results are with 10 percent), but bench scale testing produced filtrate significantly lower in total solids for polymers CB 4450 and EC 4925 . In both cases, bench scale percent solids data are 35 percent lower than the full scale percent solids data.

The total phosphorous content of filtrate that was measured at bench scale was relatively higher than the levels found at full-scale for all polymers tested. For polymer CB 4450 and EC 4925, the full scale filtrate is only about half as concentrated in total phosphorous relative to full scale. The full scale filtrate produced after using SNF 4290 to thicken sludge was about 20 percent higher in total phosphorous at bench scale than at full scale. 
Filtrate produced after using polymers SNF 4290 and EC 4925 at bench scale was very close in ammonia content to filtrate produced at full scale. Polymer CB 4450 produced filtrate at bench scale about 20 percent lower in ammonia relative to filtrate produced at full-scale.

In general, the bench scale research that was performed did not indicate that bench scale results were a uniformly accurate predictor of full scale results. In some cases however, (when examining sludge total solids, sludge total phosphorous, and filtrate ammonia), bench scale testing does approximate the relative differences between polymer types observed at full scale. The goal of the bench scale research was to identify polymers that were relatively effective when compared to other polymer types. The differences between bench scale and full scale results may be due to the fact that Phase 2 bench scale testing could not be designed to exactly match the full scale loading and timing of the full scale GBT. Because the scale of the bench scale apparatus was much smaller than the full scale GBT, it was difficult to obtain sufficiently sized samples for accurate measurement of the various physical and chemical parameters included in this study, and so the loading rate of pre-thickened sludge on the bench scale apparatus was significantly higher than on the full scale GBT. During Phase 3 bench scale testing, when the dosage range for subsequent full scale testing was determined, the loading rate and retention time of the full scale GBT was simulated, but the sample sizes of thickened sludge and filtrate were too small to perform the number of tests performed in Phase 2 bench scale testing and full scale testing. In the future, a study designed to accurately predict the composition of sludge thickened at full scale from sludge thickened at bench scale would 
require a bench scale apparatus that can simulate the full scale application, while providing samples of sufficient size to allow multiple physical and/or chemical tests to take place. 


\section{Appendix 8 - Tabulated Data}

\section{A8.1 Bench Scale Polymer Testing}

Table A8.1 - Polymer Solution Oxidation-Reduction Potential Data

\begin{tabular}{|c|c|c|c|c|c|c|c|c|c|c|}
\hline Polymer & $\begin{array}{l}\text { CB } \\
4450\end{array}$ & $\begin{array}{l}\text { CIBA } \\
7557\end{array}$ & $\begin{array}{l}\text { CIBA } \\
7587\end{array}$ & $\begin{array}{l}\text { CIBA } \\
8180\end{array}$ & $\begin{array}{l}\text { CIBA } \\
8160\end{array}$ & $\begin{array}{l}\text { JC } \\
49 \\
\end{array}$ & $\begin{array}{l}\mathrm{JC} \\
60 \\
\end{array}$ & $\begin{array}{l}\mathrm{JC} \\
473 \\
\end{array}$ & $\begin{array}{l}\text { SNF } \\
4550\end{array}$ & $\begin{array}{l}\text { SNF } \\
4140\end{array}$ \\
\hline & 210 & 208 & 217 & 215 & 270 & 269 & 260 & 246 & 250 & 237 \\
\hline & 224 & 222 & 227 & 226 & 270 & 267 & 264 & 241 & 246 & 243 \\
\hline & 240 & 232 & 238 & 232 & 268 & 261 & 268 & 254 & 226 & 246 \\
\hline & 197 & 210 & 210 & 192 & 269 & 265 & 255 & 236 & 232 & 246 \\
\hline & 224 & 224 & 227 & 226 & 266 & 259 & 253 & 257 & 241 & 253 \\
\hline & 241 & 240 & 237 & 235 & 266 & 259 & 252 & 266 & 244 & 245 \\
\hline Average & 223 & 223 & 226 & 221 & 268 & 263 & 259 & 250 & 240 & 245 \\
\hline Std Deviation & 17 & 12 & 11 & 16 & 2 & 4 & 6 & 11 & 9 & 5 \\
\hline Polymer & $\begin{array}{l}\text { SNF } \\
4190 \\
\end{array}$ & $\begin{array}{l}\text { SNF } \\
\mathbf{4 2 4 0}\end{array}$ & $\begin{array}{l}\text { SNF } \\
\mathbf{4 2 1 0}\end{array}$ & $\begin{array}{l}\text { SNF } \\
\mathbf{4 2 9 0}\end{array}$ & $\begin{array}{l}\text { SNF } \\
4700\end{array}$ & $\begin{array}{l}\text { SNF } \\
4800\end{array}$ & $\begin{array}{l}\text { EC } \\
483\end{array}$ & $\begin{array}{l}\text { EC } \\
4800\end{array}$ & \begin{tabular}{|l|}
$E C$ \\
4900
\end{tabular} & $\begin{array}{l}\text { EC } \\
4925\end{array}$ \\
\hline & 192 & 197 & 205 & 214 & 218 & 223 & 221 & 223 & 265 & 265 \\
\hline & 209 & 217 & 223 & 221 & 228 & 232 & 230 & 232 & 260 & 259 \\
\hline & 218 & 219 & 223 & 221 & 230 & 232 & 235 & 231 & 270 & 264 \\
\hline & 218 & 219 & 225 & 223 & 233 & 227 & 205 & 210 & 264 & 266 \\
\hline & 212 & 217 & 224 & 222 & 238 & 239 & 232 & 232 & 275 & 277 \\
\hline & 221 & 225 & 232 & 230 & 235 & 230 & 238 & 239 & 266 & 279 \\
\hline Average & 212 & 216 & 222 & 222 & 230 & 231 & 227 & 228 & 267 & 268 \\
\hline Std Deviation & 11 & 10 & 9 & 5 & 7 & 5 & 12 & 10 & 5 & $\overline{8}$ \\
\hline
\end{tabular}

Table A8.2 - Bench Scale Thickened Sludge Data

\begin{tabular}{|c|c|c|c|c|c|c|c|}
\hline Polymer & Trial & $\begin{array}{l}\text { Total } \\
\text { Solids } \\
(\%)\end{array}$ & TVS (\%) & $\begin{array}{l}\text { BOD } \\
(\mathbf{m g} / \mathbf{k g})\end{array}$ & $\begin{array}{l}\text { TKN } \\
(\mathbf{m g} / \mathbf{k g})\end{array}$ & $\begin{array}{l}\text { NH3-N } \\
\text { (mg/kg) }\end{array}$ & $\begin{array}{l}\text { Total P } \\
(\mathrm{mg} / \mathrm{kg})\end{array}$ \\
\hline \multirow[b]{2}{*}{ CB 4450} & 1 & 4.28 & 29.85 & 13378 & 1150 & 20 & 440 \\
\hline & 2 & 4.64 & 34.98 & N/A & 1810 & 20 & 600 \\
\hline \multirow[b]{2}{*}{ CIBA 7557} & 1 & 5.43 & 26.68 & 22033 & 2270 & 20 & 730 \\
\hline & 2 & 4.32 & 34.56 & N/A & 1390 & 20 & 570 \\
\hline \multirow[b]{2}{*}{ SNF 4140} & 1 & 4.05 & 29.39 & 14078 & 1900 & 20 & 630 \\
\hline & 2 & 2.70 & 29.36 & 13847 & 1470 & 20 & 470 \\
\hline \multirow[b]{2}{*}{ SNF 4290} & 1 & 4.40 & 29.37 & 20941 & 3390 & 20 & 1120 \\
\hline & 2 & 4.75 & 26.20 & 24967 & 3350 & 20 & 1050 \\
\hline \multirow[b]{2}{*}{ CIBA 8160} & 1 & 5.63 & 32.64 & 10398 & 3250 & 22 & 620 \\
\hline & 2 & 4.80 & 29.76 & 12685 & 3190 & 23 & 750 \\
\hline \multirow[b]{2}{*}{ EC 4925} & 1 & 4.94 & 32.62 & 11621 & 3450 & 20 & 880 \\
\hline & 2 & 5.22 & 25.75 & 11161 & 3190 & 20 & 940 \\
\hline \multirow[t]{2}{*}{ JC49 } & 1 & 0.80 & 30.74 & 10244 & 510 & 20 & 170 \\
\hline & 2 & 0.91 & 28.87 & 10022 & 510 & 20 & 170 \\
\hline
\end{tabular}




\begin{tabular}{|l|c|c|c|c|c|c|c|}
\hline & 3 & 0.69 & 44.42 & N/A & N/A & N/A & N/A \\
\hline \multirow{5}{*}{ JC473 } & 1 & 1.47 & 25.39 & 10689 & 860 & 20 & 270 \\
\hline \multirow{5}{*}{ nontrol } & 2 & 1.53 & 27.44 & 8244 & 830 & 20 & 260 \\
\cline { 2 - 8 } & 3 & 3.17 & 31.93 & N/A & N/A & N/A & N/A \\
\cline { 2 - 8 } & 1 & 1.30 & 28.56 & N/A & 1000 & 21 & 300 \\
\cline { 2 - 8 } & 2 & 1.31 & 31.11 & N/A & 890 & 20 & 280 \\
\cline { 2 - 8 } & 3 & 0.85 & 28.03 & N/A & 760 & 20 & 320 \\
\cline { 2 - 8 } & 4 & 1.33 & 29.41 & N/A & 510 & 20 & 170 \\
\cline { 2 - 8 } GBT & 1.54 & 32.87 & N/A & 570 & 20 & 190 \\
\cline { 2 - 8 } & 2 & 5.71 & 17.80 & N/A & 3290 & 70 & N/A \\
\cline { 2 - 8 } & 3 & 6.41 & 33.69 & N/A & 4140 & N/A & N/A \\
\hline
\end{tabular}

Table A8.3 - Bench Scale Filtrate Data

\begin{tabular}{|c|c|c|c|c|c|c|}
\hline Polymer & Trial & $\begin{array}{l}\text { Total Solids } \\
(\%)\end{array}$ & $\begin{array}{l}\text { TKN } \\
(\mathrm{mg} / \mathrm{L})\end{array}$ & $\begin{array}{l}\text { NH3-N } \\
\text { (mg/L) }\end{array}$ & $\begin{array}{l}\text { Total P } \\
\text { (mg/L) }\end{array}$ & $\begin{array}{l}\text { Turbidity } \\
\text { (NTU) }\end{array}$ \\
\hline \multirow[b]{2}{*}{ CB 4450} & 1 & 0.05 & 5.17 & 1.1 & 1.02 & 4.4 \\
\hline & 2 & 0.02 & 5.96 & 0.81 & 1.34 & 2.3 \\
\hline \multirow[b]{2}{*}{ CIBA 7557} & 1 & 0.06 & 5.48 & 0.64 & 1.01 & 6.3 \\
\hline & 2 & 0.00 & 4.91 & 0.71 & 1 & 2.1 \\
\hline \multirow[b]{2}{*}{ SNF 4140} & 1 & 0.07 & 2.97 & 0.57 & 0.55 & 2.6 \\
\hline & 2 & 0.06 & 2.34 & 0.11 & 0.5 & 3.3 \\
\hline \multirow[b]{2}{*}{ SNF 4290} & 1 & 0.05 & 3.03 & 0.64 & 0.48 & 1.9 \\
\hline & $\overline{2}$ & 0.06 & 2.86 & 0.15 & 0.55 & 5.0 \\
\hline \multirow[b]{2}{*}{ CIBA 8160} & 1 & 0.06 & 3.29 & 0.49 & 1.26 & 3.2 \\
\hline & 2 & 0.02 & 3.65 & 0.72 & 1.36 & 2.7 \\
\hline \multirow[b]{2}{*}{ EC 4925} & 1 & 0.04 & 3.4 & 0.23 & 1.42 & 1.3 \\
\hline & 2 & 0.05 & 3.63 & 0.52 & 1.47 & 2.0 \\
\hline \multirow[b]{3}{*}{$\mathrm{JC} 49$} & 1 & 0.05 & 9.75 & 0.16 & 3.09 & 51.8 \\
\hline & 2 & 0.03 & 8.54 & N/A & 2.69 & 53.2 \\
\hline & 3 & 0.02 & N/A & N/A & N/A & 7.1 \\
\hline \multirow[b]{3}{*}{$\mathrm{JC} 473$} & 1 & 0.04 & 3.16 & 0.15 & 0.62 & 3.7 \\
\hline & 2 & 0.02 & 4.66 & N/A & 1.27 & 29.7 \\
\hline & 3 & 0.03 & N/A & N/A & N/A & 3.1 \\
\hline \multirow[b]{3}{*}{ Control } & 1 & 0.06 & 11 & 0.78 & 3.38 & 48.4 \\
\hline & 2 & 0.05 & 7.24 & 0.04 & 2.34 & 32.5 \\
\hline & 3 & 0.05 & 5.36 & 0.04 & 2.05 & 29.4 \\
\hline \multirow[b]{2}{*}{ GBT } & 1 & 0.04 & 6.83 & 0.08 & 3.16 & 6.4 \\
\hline & 2 & 0.04 & N/A & N/A & N/A & N/A \\
\hline
\end{tabular}


Table A8.4 - Bench Scale Polymer Dosage Testing - Sludge Total Solids

\begin{tabular}{|c|c|c|c|c|c|}
\hline $\begin{array}{l}\text { Parameter } \\
\text { Polymer }\end{array}$ & \multicolumn{2}{|c|}{$\begin{array}{l}\text { Total Solids (\%) } \\
\text { CB4450 }\end{array}$} & & & \\
\hline Dosage & 0.00 & 3.75 & 4.38 & 5.00 & 5.63 \\
\hline Trial 1 & 0.57 & 5.10 & 5.43 & 4.57 & 2.15 \\
\hline Trial 2 & 0.68 & 4.65 & 5.11 & 4.61 & 2.08 \\
\hline Trial 3 & 0.60 & 4.61 & 5.25 & 4.46 & 2.15 \\
\hline Average & 0.61 & 4.79 & 5.26 & 4.54 & 2.13 \\
\hline Std. Deviation & 0.06 & 0.27 & 0.16 & 0.08 & 0.04 \\
\hline $\begin{array}{l}\text { Parameter } \\
\text { Polymer }\end{array}$ & \multicolumn{2}{|c|}{$\begin{array}{l}\text { Total Solids (\%) } \\
\text { SNF4290 }\end{array}$} & & & \\
\hline Dosage & 0.00 & 3.75 & 4.38 & 5.00 & 5.63 \\
\hline \multirow{3}{*}{$\begin{array}{l}\text { Trial } 1 \\
\text { Trial } 2 \\
\text { Trial } 3 \\
\end{array}$} & 0.78 & 4.88 & 5.65 & 5.22 & 2.12 \\
\hline & 0.46 & 5.12 & 6.12 & 4.87 & 3.55 \\
\hline & N/A & 5.09 & 5.51 & 5.03 & 1.53 \\
\hline Average & 0.62 & 5.03 & 5.76 & 5.04 & 2.40 \\
\hline Std. Deviation & 0.23 & 0.13 & 0.32 & 0.18 & 1.04 \\
\hline $\begin{array}{l}\text { Parameter } \\
\text { Polymer }\end{array}$ & \multicolumn{2}{|c|}{$\begin{array}{l}\text { Total Solids (\%) } \\
\text { EC4925 }\end{array}$} & & & \\
\hline Dosage & 0.00 & 3.75 & 4.38 & 5.00 & 5.63 \\
\hline \multirow{3}{*}{$\begin{array}{l}\text { Trial } 1 \\
\text { Trial } 2 \\
\text { Trial } 3 \\
\end{array}$} & 0.83 & 5.08 & 5.27 & 2.84 & 2.89 \\
\hline & 0.68 & 4.64 & 5.42 & 5.28 & 3.67 \\
\hline & 0.84 & 5.60 & 5.15 & 2.89 & 3.03 \\
\hline Average & 0.78 & 5.11 & 5.28 & 3.67 & 3.19 \\
\hline Std. Deviation & 0.09 & 0.48 & 0.14 & 1.39 & 0.42 \\
\hline
\end{tabular}


Table A8.5 - Bench Scale Polymer Dosage Testing - Sludge TKN Concentration

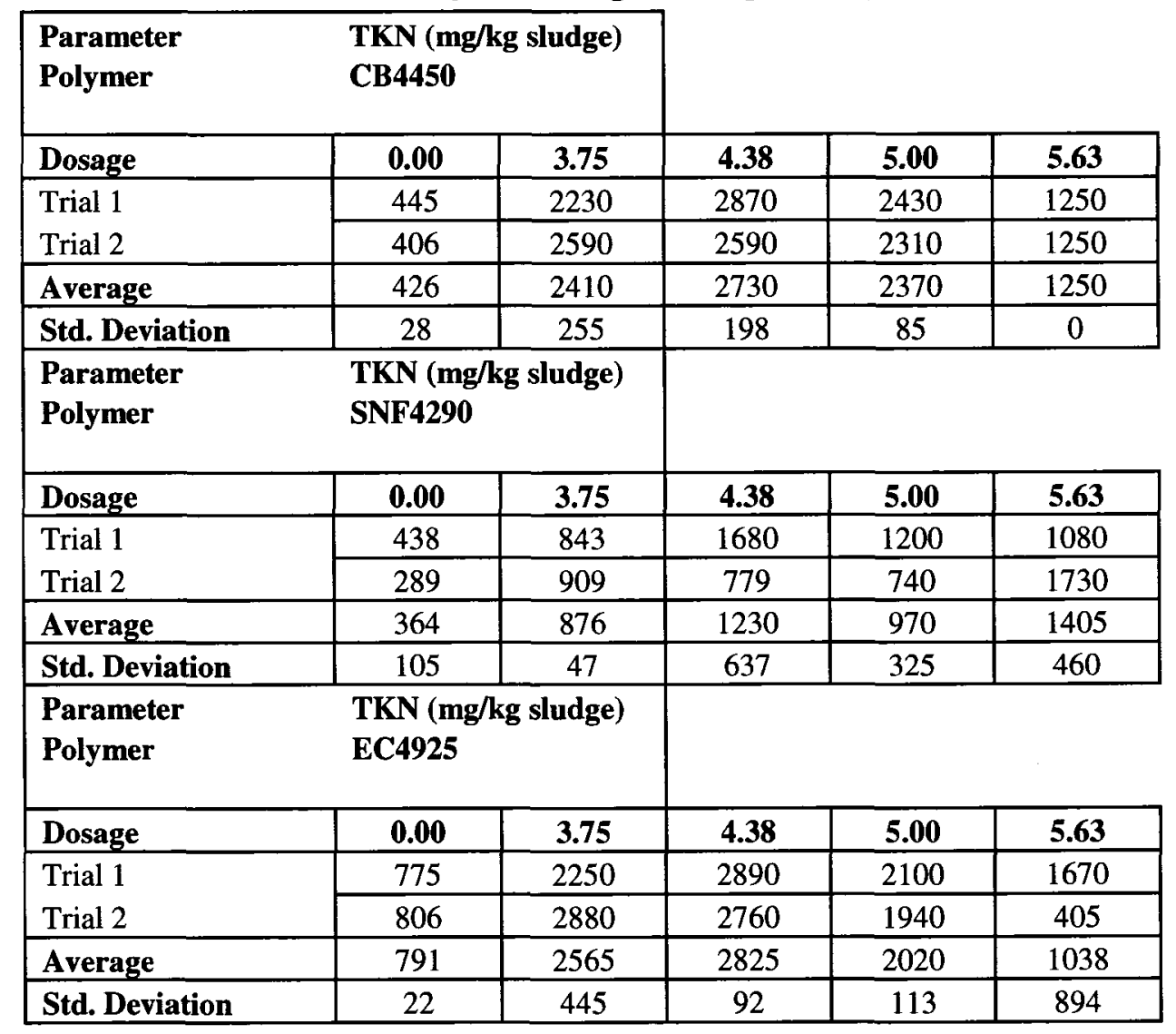


Table A8.6 - Bench Scale Polymer Dosage Testing - Sludge Total Phosphorous Concentration

\begin{tabular}{|c|c|c|c|c|c|}
\hline $\begin{array}{l}\text { Parameter } \\
\text { Polymer }\end{array}$ & \multicolumn{2}{|c|}{$\begin{array}{l}\text { P (mg/kg sludge) } \\
\text { CB4450 }\end{array}$} & & & \\
\hline Dosage & 0.00 & 3.75 & 4.38 & 5.00 & 5.63 \\
\hline Trial 1 & 144 & 733 & 940 & 791 & 415 \\
\hline Trial 2 & 125 & 857 & 838 & 741 & 405 \\
\hline Average & 135 & 795 & 889 & 766 & 410 \\
\hline Std. Deviation & 13 & 88 & 72 & 35 & 7 \\
\hline $\begin{array}{l}\text { Parameter } \\
\text { Polymer }\end{array}$ & \multicolumn{2}{|c|}{$\begin{array}{l}\text { P (mg/kg sludge) } \\
\text { SNF4290 }\end{array}$} & & & \\
\hline Dosage & 0.00 & 3.75 & 4.38 & 5.00 & 5.63 \\
\hline \multirow{2}{*}{$\begin{array}{l}\text { Trial } 1 \\
\text { Trial } 2 \\
\end{array}$} & 156 & 288 & 580 & 455 & 403 \\
\hline & 103 & 317 & 269 & 249 & 609 \\
\hline Average & 130 & 303 & 425 & 352 & 506 \\
\hline Std. Deviation & 37 & 21 & 220 & 146 & 146 \\
\hline $\begin{array}{l}\text { Parameter } \\
\text { Polymer }\end{array}$ & \multicolumn{2}{|c|}{$\begin{array}{l}\text { P (mg/kg sludge) } \\
\text { EC4925 }\end{array}$} & & & \\
\hline Dosage & 0.00 & 3.75 & 4.38 & 5.00 & 5.63 \\
\hline Trial 1 & 190 & 907 & 830 & 756 & 505 \\
\hline Trial 2 & 142 & 722 & 920 & 766 & 470 \\
\hline Average & 166 & 815 & 875 & 761 & 488 \\
\hline Std. Deviation & 34 & 131 & 64 & 7 & 25 \\
\hline
\end{tabular}


Table A8.7 - Bench Scale Polymer Dosage Testing - Filtrate Total Solids

\begin{tabular}{|c|c|c|c|c|c|}
\hline $\begin{array}{l}\text { Parameter } \\
\text { Polymer }\end{array}$ & \multicolumn{2}{|c|}{$\begin{array}{l}\text { Total Solids (\%) } \\
\text { CB4450 }\end{array}$} & & & \\
\hline Dosage & 0.00 & 3.75 & 4.38 & 5.00 & 5.63 \\
\hline Trial 1 & 0.14 & 0.08 & 0.05 & 0.04 & 0.04 \\
\hline Trial 2 & 0.24 & 0.06 & 0.05 & 0.03 & 0.01 \\
\hline Trial 3 & 0.12 & 0.06 & 0.05 & 0.03 & 0.03 \\
\hline Average & 0.17 & 0.06 & 0.05 & 0.03 & 0.03 \\
\hline Std. Deviation & 0.06 & 0.01 & 0.00 & 0.01 & 0.01 \\
\hline $\begin{array}{l}\text { Parameter } \\
\text { Polymer }\end{array}$ & \multicolumn{2}{|c|}{ Total Solids (\%) } & & & \\
\hline Dosage & 0.00 & 3.75 & 4.38 & 5.00 & 5.63 \\
\hline \multirow{3}{*}{$\begin{array}{l}\text { Trial } 1 \\
\text { Trial } 2 \\
\text { Trial 3 }\end{array}$} & 0.14 & 0.07 & 0.06 & 0.04 & 0.04 \\
\hline & 0.27 & 0.07 & 0.08 & 0.06 & 0.04 \\
\hline & N/A & 0.07 & 0.03 & 0.03 & 0.03 \\
\hline Average & 0.20 & 0.07 & 0.06 & 0.04 & 0.04 \\
\hline Std. Deviation & 0.09 & 0.00 & 0.03 & 0.02 & 0.01 \\
\hline $\begin{array}{l}\text { Parameter } \\
\text { Polymer }\end{array}$ & \multicolumn{2}{|c|}{$\begin{array}{l}\text { Total Solids (\%) } \\
\text { EC4925 }\end{array}$} & & & \\
\hline Dosage & 0.00 & 3.75 & 4.38 & 5.00 & 5.63 \\
\hline \multirow{3}{*}{$\begin{array}{l}\text { Trial } 1 \\
\text { Trial } 2 \\
\text { Trial } 3\end{array}$} & 0.11 & 0.02 & 0.03 & 0.03 & 0.06 \\
\hline & 0.11 & 0.04 & 0.03 & 0.06 & 0.05 \\
\hline & 0.11 & 0.03 & 0.03 & 0.05 & 0.06 \\
\hline Average & 0.11 & 0.03 & 0.03 & 0.05 & 0.05 \\
\hline Std. Deviation & 0.00 & 0.01 & 0.00 & 0.02 & 0.00 \\
\hline
\end{tabular}


Table A8.8 - Bench Scale Polymer Dosage Testing - Filtrate Turbidity

\begin{tabular}{|c|c|c|c|c|c|c|}
\hline $\begin{array}{l}\text { Parameter } \\
\text { Polymer }\end{array}$ & \multicolumn{2}{|c|}{$\begin{array}{l}\text { Turbidity (NTU) } \\
\text { CB4450 }\end{array}$} & & & & \\
\hline Dosage & 2.25 & 3 & 3.75 & 4.5 & 5.25 & 6 \\
\hline Trial 1 & 102 & 8 & 2 & 2 & 4 & 12 \\
\hline Trial 2 & 89 & 9 & 2 & 3 & 5 & 9 \\
\hline Trial 3 & 87 & 10 & 2 & 2 & 4 & 11 \\
\hline Average & 92.7 & 9.0 & 2.0 & 2.1 & 4.2 & 11.1 \\
\hline Std. Deviation & 8.1 & 0.8 & 0.2 & 0.4 & 0.3 & 1.5 \\
\hline $\begin{array}{l}\text { Parameter } \\
\text { Polymer }\end{array}$ & \multicolumn{2}{|c|}{$\begin{array}{l}\text { Turbidity (NTU) } \\
\text { SNF4290 }\end{array}$} & & & & \\
\hline Dosage & 2.25 & 3 & 3.75 & 4.5 & 5.25 & 6 \\
\hline \multirow{3}{*}{$\begin{array}{l}\text { Trial } 1 \\
\text { Trial } 2 \\
\text { Trial 3 } \\
\end{array}$} & N/A & 108 & 8 & 2 & 3 & 9 \\
\hline & N/A & 92 & 7 & 2 & 3 & 12 \\
\hline & N/A & 87 & 6 & 2 & 7 & 23 \\
\hline Average & N/A & 95.7 & 7.0 & 1.9 & 4.1 & 14.6 \\
\hline Std. Deviation & N/A & 11.0 & 0.8 & 0.3 & 2.2 & 7.5 \\
\hline $\begin{array}{l}\text { Parameter } \\
\text { Polymer }\end{array}$ & \multicolumn{2}{|c|}{$\begin{array}{l}\text { Turbidity (NTU) } \\
\text { EC4925 }\end{array}$} & & & & \\
\hline Dosage & 2.25 & 3 & 3.75 & 4.5 & 5.25 & 6 \\
\hline \multirow{3}{*}{$\begin{array}{l}\text { Trial } 1 \\
\text { Trial } 2 \\
\text { Trial } 3 \\
\end{array}$} & 142 & 43 & 3 & 1 & 2 & 13 \\
\hline & 112 & 22 & 3 & 2 & 4 & 14 \\
\hline & 134 & 34 & 4 & 2 & 4 & 21 \\
\hline Average & 129.3 & 33.0 & 3.3 & 1.7 & 3.5 & 15.8 \\
\hline Std. Deviation & 15.5 & 10.5 & 0.7 & 0.5 & 1.0 & 4.7 \\
\hline
\end{tabular}


Table A8.9 - Bench Scale Polymer Dosage Testing - Filtrate Ammonia Concentration

\begin{tabular}{|c|c|c|c|c|c|}
\hline $\begin{array}{l}\text { Parameter } \\
\text { Polymer }\end{array}$ & \multicolumn{2}{|c|}{$\begin{array}{l}\mathrm{NH}_{3}(\mathrm{mg} / \mathrm{L} \text { filtrate) } \\
\mathrm{CB} 4450\end{array}$} & & & \\
\hline Dosage & 0.00 & 3.75 & 4.38 & 5.00 & 5.63 \\
\hline Trial 1 & 0.27 & 0.09 & 0.15 & 0.70 & 0.91 \\
\hline Trial 2 & 0.88 & 0.41 & 0.62 & 1.42 & 1.10 \\
\hline Average & 0.58 & 0.25 & 0.39 & 1.06 & 1.01 \\
\hline Std. Deviation & 0.43 & 0.23 & 0.33 & 0.51 & 0.13 \\
\hline $\begin{array}{l}\text { Parameter } \\
\text { Polymer }\end{array}$ & \multicolumn{2}{|c|}{$\begin{array}{l}\mathrm{NH}_{3} \text { (mg/L filtrate) } \\
\mathrm{SNF4290}\end{array}$} & & & \\
\hline Dosage & 0.00 & 3.75 & 4.38 & 5.00 & 5.63 \\
\hline \multirow{2}{*}{$\begin{array}{l}\text { Trial } 1 \\
\text { Trial } 2\end{array}$} & 0.66 & 0.17 & 0.27 & 0.48 & 0.77 \\
\hline & 1.40 & 0.30 & 0.46 & 0.55 & 0.65 \\
\hline Average & 1.03 & 0.24 & 0.37 & 0.52 & 0.71 \\
\hline Std. Deviation & 0.52 & 0.09 & 0.13 & 0.05 & 0.08 \\
\hline $\begin{array}{l}\text { Parameter } \\
\text { Polymer }\end{array}$ & \multicolumn{2}{|c|}{$\begin{array}{l}\mathrm{NH}_{3}(\mathrm{mg} / \mathrm{L} \text { filtrate }) \\
\mathrm{EC4925}\end{array}$} & & & \\
\hline Dosage & 0.00 & 3.75 & 4.38 & 5.00 & 5.63 \\
\hline Trial 1 & 0.22 & 1.27 & 1.50 & 2.62 & 2.86 \\
\hline Trial 2 & 0.23 & 1.21 & 1.39 & 2.89 & 2.74 \\
\hline Average & 0.23 & 1.24 & 1.45 & 2.76 & 2.80 \\
\hline Std. Deviation & 0.01 & 0.04 & 0.08 & 0.19 & 0.08 \\
\hline
\end{tabular}


Table A8.10 - Bench Scale Polymer Dosage Testing - Filtrate Total Phosphorous Concentration

\begin{tabular}{|c|c|c|c|c|c|}
\hline $\begin{array}{l}\text { Parameter } \\
\text { Polymer }\end{array}$ & \multicolumn{2}{|c|}{$\begin{array}{l}P \text { (mg/L filtrate) } \\
\text { CB4450 }\end{array}$} & & & \\
\hline Dosage & 0.00 & 3.75 & 4.38 & 5.00 & 5.63 \\
\hline Trial 1 & 28.90 & 0.23 & 0.60 & 0.27 & 0.41 \\
\hline Trial 2 & 46.80 & 0.20 & 0.13 & 0.51 & 0.44 \\
\hline Average & 37.85 & 0.22 & 0.37 & 0.39 & 0.43 \\
\hline Std. Deviation & 12.66 & 0.02 & 0.33 & 0.17 & 0.02 \\
\hline $\begin{array}{l}\text { Parameter } \\
\text { Polymer }\end{array}$ & \multicolumn{2}{|c|}{$\begin{array}{l}\text { P (mg/L filtrate) } \\
\text { SNF4290 }\end{array}$} & & & \\
\hline Dosage & 0.00 & 3.75 & 4.38 & 5.00 & 5.63 \\
\hline \multirow{2}{*}{$\begin{array}{l}\text { Trial } 1 \\
\text { Trial } 2\end{array}$} & 25.30 & 7.00 & 5.30 & 4.45 & 2.22 \\
\hline & $\geq 50$ & 8.60 & 9.70 & 5.30 & 2.25 \\
\hline Average & N/A & 7.80 & 7.50 & 4.88 & 2.24 \\
\hline Std. Deviation & N/A & 1.13 & 3.11 & 0.60 & 0.02 \\
\hline $\begin{array}{l}\text { Parameter } \\
\text { Polymer }\end{array}$ & \multicolumn{2}{|c|}{$\begin{array}{l}\text { P (mg/L filtrate) } \\
\text { EC4925 }\end{array}$} & & & \\
\hline Dosage & 0.00 & 3.75 & 4.38 & 5.00 & 5.63 \\
\hline Trial 1 & 13.80 & 0.44 & 0.75 & 0.99 & 1.53 \\
\hline Trial 2 & 28.30 & 0.47 & 0.71 & 1.04 & 1.55 \\
\hline Average & 21.05 & 0.46 & 0.73 & 1.02 & 1.54 \\
\hline Std. Deviation & 10.25 & 0.02 & 0.03 & 0.04 & 0.01 \\
\hline
\end{tabular}

Table A8.11 - Bench Scale Polymer Dosage Testing - Filtrate Total BOD Concentration

\begin{tabular}{|l|c|c|c|c|c|}
\hline Parameter & \multicolumn{3}{|c|}{} \\
\hline Dosage & $\mathbf{0 . 0 0}$ & $\mathbf{3 . 7 5}$ & $\mathbf{4 . 3 8}$ & $\mathbf{5 . 0 0}$ & $\mathbf{5 . 6 3}$ \\
\hline CB 4450 & N/A & 357 & 355 & 91 & 334 \\
\cline { 2 - 6 } SNF 4290 & N/A & 339 & 293 & 162 & 317 \\
\cline { 2 - 6 } EC 4925 & N/A & 394 & 261 & 150 & 83 \\
\hline
\end{tabular}




\section{A8.2 Full Scale Polymer Testing}

Table A8.12 - Full Scale Thickened Sludge Data - Total Solids

\begin{tabular}{|c|c|c|c|c|c|c|c|c|}
\hline \multirow{2}{*}{\multicolumn{2}{|c|}{$\begin{array}{l}\text { Parameter } \\
\text { Polymer } \\
\text { Dosage } \\
\end{array}$}} & \multicolumn{2}{|c|}{$\begin{array}{l}\text { Total Solids (\%) } \\
\text { CB4450 }\end{array}$} & \multirow[b]{2}{*}{3.65} & \multirow[b]{2}{*}{4.55} & \multirow[b]{2}{*}{5.45} & \multirow[b]{2}{*}{6.35} & \multirow[b]{2}{*}{7.25} \\
\hline & & 1.85 & 2.75 & & & & & \\
\hline \multirow[t]{3}{*}{ Week 1} & Trial 1 & N/A & 1.50 & 5.47 & 5.70 & 5.62 & 6.91 & 6.44 \\
\hline & Trial 2 & N/A & 1.61 & 5.29 & 5.70 & 5.56 & 5.79 & 5.99 \\
\hline & Trial 3 & N/A & 1.79 & 5.82 & 5.78 & 5.95 & 6.21 & 5.78 \\
\hline \multirow[t]{3}{*}{ Week 2} & Trial 1 & N/A & 1.77 & 4.10 & 5.90 & 5.65 & 5.70 & 5.44 \\
\hline & Trial 2 & N/A & 1.65 & 4.49 & 6.01 & 5.24 & 6.27 & 5.20 \\
\hline & Trial 3 & N/A & 1.86 & 4.08 & 6.05 & 5.81 & 5.95 & 5.84 \\
\hline \multicolumn{2}{|l|}{ Average } & & 1.69 & 4.87 & 5.85 & 5.64 & 6.14 & 5.78 \\
\hline \multicolumn{2}{|c|}{ Standard deviation } & & 0.13 & 0.75 & 0.16 & 0.24 & 0.44 & 0.43 \\
\hline \multicolumn{4}{|c|}{$\begin{array}{l}\text { Parameter } \\
\text { Polymer }\end{array}$} & & & & & \\
\hline \multicolumn{2}{|l|}{ Dosage } & 1.85 & 2.75 & 3.65 & 4.55 & 5.45 & 6.35 & 7.25 \\
\hline \multirow[t]{3}{*}{ Week 1} & Trial 1 & 1.06 & 4.38 & 4.83 & 5.68 & 6.12 & 6.29 & N/A \\
\hline & Trial 2 & 1.21 & 4.57 & 4.48 & 5.43 & 6.30 & 6.46 & N/A \\
\hline & Trial 3 & 0.97 & 4.57 & 4.65 & 5.75 & 6.71 & 6.05 & N/A \\
\hline \multirow[t]{3}{*}{ Week 2} & Trial 1 & 1.16 & 3.85 & 4.23 & 4.20 & 4.84 & 5.23 & N/A \\
\hline & Trial 2 & 1.07 & 4.18 & 4.32 & 4.55 & 5.21 & 5.80 & N/A \\
\hline & Trial 3 & 1.04 & 4.02 & 4.13 & 4.04 & 5.10 & 6.01 & N/A \\
\hline \multicolumn{2}{|l|}{ Average } & 1.09 & 4.26 & 4.44 & 4.94 & 5.71 & 5.97 & \\
\hline \multicolumn{2}{|c|}{ Standard deviation } & 0.08 & 0.30 & 0.26 & 0.77 & 0.76 & 0.43 & \\
\hline \multicolumn{2}{|c|}{$\begin{array}{l}\text { Parameter } \\
\text { Polymer }\end{array}$} & \multicolumn{2}{|c|}{$\begin{array}{l}\text { Total Solids (\%) } \\
\text { EC4925 }\end{array}$} & & & & & \\
\hline \multicolumn{2}{|l|}{ Dosage } & 1.85 & 2.75 & 3.65 & 4.55 & 5.45 & 6.35 & 7.25 \\
\hline \multirow[t]{3}{*}{ Week 1} & Trial 1 & 3.52 & 3.97 & 4.56 & 4.77 & 5.01 & 5.24 & N/A \\
\hline & Trial 2 & 4.09 & 3.97 & 4.11 & 4.57 & 4.68 & 5.55 & N/A \\
\hline & Trial 3 & 3.38 & 4.08 & 4.52 & 4.42 & 5.11 & 5.44 & N/A \\
\hline \multirow[t]{3}{*}{ Week 2} & Trial 1 & N/A & 4.72 & 5.67 & 5.66 & 4.88 & 4.10 & 4.59 \\
\hline & Trial 2 & N/A & 4.87 & 5.72 & 5.39 & 4.19 & 3.84 & 5.04 \\
\hline & Trial 3 & N/A & 4.62 & 5.68 & 5.43 & 4.74 & 4.38 & 4.81 \\
\hline \multicolumn{2}{|c|}{ Average } & 3.66 & 4.37 & 5.04 & 5.04 & 4.77 & 4.76 & 4.81 \\
\hline \multicolumn{2}{|c|}{ Standard deviation } & 0.38 & 0.41 & 0.73 & 0.52 & 0.32 & 0.74 & 0.22 \\
\hline
\end{tabular}


Table A8.13 - Full Scale Thickened Sludge Data - TKN Concentration

\begin{tabular}{|c|c|c|c|c|c|c|c|c|}
\hline \multirow{2}{*}{\multicolumn{2}{|c|}{$\begin{array}{l}\begin{array}{l}\text { Parameter } \\
\text { Polymer }\end{array} \\
\text { Dosage } \\
\end{array}$}} & \multicolumn{2}{|c|}{$\begin{array}{l}\text { TKN (mg/kg sludge) } \\
\text { CB4450 }\end{array}$} & \multirow[b]{2}{*}{3.65} & \multirow[b]{2}{*}{4.55} & \multirow[b]{2}{*}{5.45} & \multirow[b]{2}{*}{6.35} & \multirow[b]{2}{*}{7.25} \\
\hline & & 1.85 & 2.75 & & & & & \\
\hline \multirow[t]{3}{*}{ Week 1} & \multirow{3}{*}{$\begin{array}{l}\text { Trial 1 } \\
\text { Trial } 2 \\
\text { Trial 3 }\end{array}$} & N/A & 1060 & 2860 & 3420 & 3470 & 3280 & 3030 \\
\hline & & N/A & 900 & 2930 & 3280 & 3370 & 3060 & 2940 \\
\hline & & N/A & 960 & 3480 & 3150 & 3250 & 3160 & 3270 \\
\hline \multirow[t]{3}{*}{ Week 2} & \multirow{3}{*}{$\begin{array}{l}\text { Trial } 1 \\
\text { Trial } 2 \\
\text { Trial } 3\end{array}$} & N/A & 970 & 2890 & 3480 & 3200 & 2680 & 3150 \\
\hline & & N/A & 960 & 2470 & 3320 & 3600 & 2960 & 3220 \\
\hline & & N/A & 1080 & 2930 & 3540 & 3800 & 2880 & 2600 \\
\hline \multicolumn{2}{|l|}{ Average } & & 990 & 2927 & 3365 & 3448 & 3003 & 3035 \\
\hline \multicolumn{2}{|c|}{ Standard deviation } & & 68 & 323 & 143 & 226 & 213 & 245 \\
\hline \multicolumn{2}{|c|}{$\begin{array}{l}\text { Parameter } \\
\text { Polymer }\end{array}$} & \multicolumn{2}{|c|}{$\begin{array}{l}\text { TKN (mg/kg sludge) } \\
\text { SNF4290 }\end{array}$} & & & & & \\
\hline \multicolumn{2}{|l|}{ Dosage } & 1.85 & 2.75 & 3.65 & 4.55 & 5.45 & 6.35 & 7.25 \\
\hline \multirow[t]{3}{*}{ Week 1} & \multirow{3}{*}{$\begin{array}{l}\text { Trial 1 } \\
\text { Trial 2 } \\
\text { Trial 3 }\end{array}$} & 2030 & 2230 & 2850 & 2200 & 2680 & 2030 & N/A \\
\hline & & 1880 & 1940 & 2380 & 2420 & 2830 & 1880 & N/A \\
\hline & & 1950 & 2060 & 2210 & 2300 & 2610 & 1950 & N/A \\
\hline \multirow[t]{3}{*}{ Week 2} & \multirow{3}{*}{$\begin{array}{l}\text { Trial 1 } \\
\text { Trial } 2 \\
\text { Trial } 3\end{array}$} & 2520 & 3140 & 2690 & 2519 & 2080 & 2210 & N/A \\
\hline & & 2380 & 2910 & 2890 & 3190 & 2240 & 2070 & N/A \\
\hline & & 2350 & 2440 & 2600 & 2090 & 2520 & 2920 & $\mathrm{~N} / \mathrm{A}$ \\
\hline \multicolumn{2}{|l|}{ Average } & 2185 & 2453 & 2603 & 2453 & 2493 & 2177 & \\
\hline \multicolumn{2}{|c|}{ Standard deviation } & 264 & 479 & 267 & 392 & 282 & 381.0337 & \\
\hline \multicolumn{4}{|c|}{$\begin{array}{l}\text { Parameter } \\
\text { Polymer }\end{array}$} & & & & & \\
\hline \multicolumn{2}{|l|}{ Dosage } & 1.85 & 2.75 & 3.65 & 4.55 & 5.45 & 6.35 & 7.25 \\
\hline \multirow[t]{3}{*}{ Week 1} & \multirow{3}{*}{$\begin{array}{l}\text { Trial } 1 \\
\text { Trial } 2 \\
\text { Trial } 3\end{array}$} & 620 & 2410 & 2770 & 3280 & 3430 & 3500 & N/A \\
\hline & & 570 & 2840 & 2610 & 3190 & 3060 & 3170 & N/A \\
\hline & & 630 & 2600 & 2510 & 3190 & 3640 & 3780 & N/A \\
\hline \multirow[t]{3}{*}{ Week 2} & \multirow{3}{*}{$\begin{array}{l}\text { Trial } 1 \\
\text { Trial } 2 \\
\text { Trial } 3\end{array}$} & N/A & 590 & 2250 & 2250 & 2120 & 2680 & 3150 \\
\hline & & N/A & 600 & 2270 & 2250 & 2780 & 2960 & 3220 \\
\hline & & N/A & 520 & 2470 & 2130 & 2340 & 2880 & 2600 \\
\hline \multicolumn{2}{|l|}{ Average } & 606 & 1592 & 2480 & 2715 & 2895 & 3162 & 2990 \\
\hline \multicolumn{2}{|c|}{\begin{tabular}{|l|} 
Standard deviation \\
\end{tabular}} & 29 & 1131 & 200 & 556 & 598 & 412 & 340 \\
\hline
\end{tabular}


Table A8.14 - Full Scale Thickened Sludge Data - Total Phosphorous Concentration

\begin{tabular}{|c|c|c|c|c|c|c|c|c|}
\hline \multirow{2}{*}{\multicolumn{2}{|c|}{$\begin{array}{l}\text { Parameter } \\
\text { Polymer } \\
\text { Dosage } \\
\end{array}$}} & \multicolumn{2}{|c|}{$\begin{array}{l}P(\mathrm{mg} / \mathrm{kg} \text { sludge }) \\
\mathrm{CB4450}\end{array}$} & \multirow[b]{2}{*}{3.65} & \multirow[b]{2}{*}{4.55} & \multirow[b]{2}{*}{5.45} & \multirow[b]{2}{*}{6.35} & \multirow[b]{2}{*}{7.25} \\
\hline & & 1.85 & 2.75 & & & & & \\
\hline \multirow[t]{3}{*}{ Week 1} & Trial 1 & N/A & 320 & 850 & 1040 & 1050 & 1010 & 950 \\
\hline & Trial 2 & N/A & 270 & 860 & 990 & 1010 & 960 & 930 \\
\hline & Trial 3 & N/A & 280 & 1050 & 950 & 980 & 1000 & 1040 \\
\hline \multirow[t]{3}{*}{ Week 2} & Trial 1 & N/A & 360 & 1050 & 1440 & 1130 & 900 & 1050 \\
\hline & Trial 2 & N/A & 360 & 900 & 1170 & 1260 & 1010 & 1050 \\
\hline & Trial 3 & N/A & 390 & 1050 & 1230 & 1320 & 990 & 880 \\
\hline \multicolumn{2}{|l|}{ Average } & & 330 & 960 & 1138 & 1125 & 978 & 983 \\
\hline \multicolumn{2}{|c|}{ Standard deviation } & & 47 & 100 & 182 & 139 & 43 & 73 \\
\hline \multicolumn{2}{|c|}{$\begin{array}{l}\text { Parameter } \\
\text { Polymer }\end{array}$} & \multicolumn{2}{|c|}{$\begin{array}{l}\text { P (mg/kg sludge) } \\
\text { SNF4290 }\end{array}$} & & & & & \\
\hline \multicolumn{2}{|l|}{ Dosage } & 1.85 & 2.75 & 3.65 & 4.55 & 5.45 & 6.35 & 7.25 \\
\hline \multirow[t]{3}{*}{ Week 1} & Trial 1 & 690 & 760 & 970 & 790 & 900 & 890 & N/A \\
\hline & Trial 2 & 650 & 680 & 860 & 870 & 950 & 950 & N/A \\
\hline & Trial 3 & 670 & 720 & 800 & 830 & 880 & 1160 & N/A \\
\hline \multirow[t]{3}{*}{ Week 2} & Trial 1 & 830 & 1020 & 850 & 820 & 680 & 720 & N/A \\
\hline & Trial 2 & 750 & 950 & 910 & 1060 & 710 & 660 & N/A \\
\hline & Trial 3 & 760 & 780 & 820 & 690 & 810 & 930 & N/A \\
\hline \multicolumn{2}{|l|}{ Average } & 723 & 818 & 869 & 843 & 820 & 883 & \\
\hline \multicolumn{2}{|c|}{ Standard deviation } & 65 & 135 & 64 & 123 & 108 & 178 & \\
\hline \multicolumn{2}{|c|}{$\begin{array}{l}\text { Parameter } \\
\text { Polymer }\end{array}$} & \multicolumn{2}{|c|}{$\begin{array}{l}\text { P (mg/kg sludge) } \\
\text { EC4925 }\end{array}$} & & & & & \\
\hline \multicolumn{2}{|l|}{ Dosage } & 1.85 & 2.75 & 3.65 & 4.55 & 5.45 & 6.35 & 7.25 \\
\hline \multirow[t]{3}{*}{ Week 1} & Trial 1 & 300 & 840 & 970 & 1130 & 1130 & 1140 & N/A \\
\hline & Trial 2 & 270 & 990 & 920 & 1100 & 990 & 1030 & N/A \\
\hline & Trial 3 & 270 & 910 & 890 & 1090 & 1150 & 1230 & N/A \\
\hline \multirow[t]{3}{*}{ Week 2} & Trial 1 & N/A & 210 & 760 & 800 & 810 & 900 & 1050 \\
\hline & Trial 2 & N/A & 210 & 790 & 820 & 960 & 1010 & 1050 \\
\hline & Trial 3 & N/A & 190 & 850 & 910 & 810 & 990 & 880 \\
\hline \multicolumn{2}{|l|}{ Average } & 281 & 561 & 862 & 958 & 975 & 1050 & 993 \\
\hline \multicolumn{2}{|c|}{ Standard deviation } & 18 & 391 & 78 & 164 & 149 & 117 & 98 \\
\hline
\end{tabular}


Table A8.15 - Full Scale Filtrate Data - Percent Total Solids

\begin{tabular}{|c|c|c|c|c|c|c|c|c|}
\hline \multirow{2}{*}{\multicolumn{2}{|c|}{$\begin{array}{l}\text { Parameter } \\
\text { Polymer } \\
\text { Dosage } \\
\end{array}$}} & \multicolumn{2}{|c|}{$\begin{array}{l}\text { Total Solids (\%) } \\
\text { CB4450 }\end{array}$} & \multirow[b]{2}{*}{3.65} & \multirow[b]{2}{*}{4.55} & \multirow[b]{2}{*}{5.45} & \multirow[b]{2}{*}{6.35} & \multirow[b]{2}{*}{7.25} \\
\hline & & 1.85 & 2.75 & & & & & \\
\hline \multirow[t]{3}{*}{ Week 1} & Trial 1 & N/A & 0.37 & 0.06 & 0.08 & 0.04 & 0.08 & 0.05 \\
\hline & Trial 2 & N/A & 0.45 & 0.04 & 0.07 & 0.01 & 0.07 & 0.06 \\
\hline & Trial 3 & N/A & 0.40 & 0.05 & 0.02 & 0.03 & 0.07 & 0.06 \\
\hline \multirow[t]{3}{*}{ Week 2} & Trial 1 & N/A & 0.10 & 0.07 & 0.06 & 0.06 & 0.06 & 0.07 \\
\hline & Trial 2 & N/A & 0.12 & 0.05 & 0.07 & 0.06 & 0.06 & 0.06 \\
\hline & Trial 3 & N/A & 0.11 & 0.08 & 0.06 & 0.06 & 0.07 & 0.06 \\
\hline \multicolumn{2}{|l|}{ Average } & & 0.26 & 0.06 & 0.06 & 0.04 & 0.07 & 0.06 \\
\hline \multicolumn{2}{|c|}{ Standard deviation } & & 0.16 & 0.01 & 0.02 & 0.02 & 0.01 & 0.01 \\
\hline \multicolumn{2}{|c|}{$\begin{array}{l}\text { Parameter } \\
\text { Polymer }\end{array}$} & \multicolumn{2}{|c|}{$\begin{array}{l}\text { Total Solids (\%) } \\
\text { SNF4290 }\end{array}$} & & & & & \\
\hline \multicolumn{2}{|l|}{ Dosage } & 1.85 & 2.75 & 3.65 & 4.55 & 5.45 & 6.35 & 7.25 \\
\hline \multirow[t]{3}{*}{ Week 1} & Trial 1 & 0.23 & 0.07 & 0.05 & 0.06 & 0.02 & 0.04 & N/A \\
\hline & Trial 2 & 0.27 & 0.07 & 0.07 & 0.05 & 0.04 & 0.03 & N/A \\
\hline & Trial 3 & 0.23 & 0.07 & 0.07 & 0.06 & 0.02 & 0.05 & N/A \\
\hline \multirow[t]{3}{*}{ Week 2} & Trial 1 & 0.44 & 0.10 & 0.06 & 0.04 & 0.06 & 0.05 & N/A \\
\hline & Trial 2 & 0.54 & 0.10 & 0.07 & 0.03 & 0.06 & 0.06 & N/A \\
\hline & Trial 3 & 0.47 & 0.10 & 0.04 & 0.06 & 0.06 & 0.06 & N/A \\
\hline \multicolumn{2}{|l|}{ Average } & 0.36 & 0.08 & 0.06 & 0.05 & 0.04 & 0.05 & \\
\hline \multicolumn{2}{|c|}{ Standard deviation } & 0.13 & 0.01 & 0.01 & 0.01 & 0.02 & 0.01 & \\
\hline \multicolumn{2}{|c|}{$\begin{array}{l}\text { Parameter } \\
\text { Polymer }\end{array}$} & \multicolumn{2}{|c|}{$\begin{array}{l}\text { Total Solids (\%) } \\
\text { EC4925 }\end{array}$} & & & & & \\
\hline \multicolumn{2}{|l|}{ Dosage } & 1.85 & 2.75 & 3.65 & 4.55 & 5.45 & 6.35 & 7.25 \\
\hline \multirow[t]{3}{*}{ Week 1} & Trial 1 & 0.06 & 0.06 & 0.05 & 0.07 & 0.06 & 0.06 & N/A \\
\hline & Trial 2 & 0.08 & 0.06 & 0.07 & 0.07 & 0.06 & 0.07 & N/A \\
\hline & Trial 3 & 0.08 & 0.06 & 0.06 & 0.07 & 0.06 & 0.06 & N/A \\
\hline \multirow[t]{3}{*}{ Week 2} & Trial 1 & N/A & 0.06 & 0.03 & 0.06 & 0.05 & 0.06 & 0.04 \\
\hline & Trial 2 & N/A & 0.01 & 0.05 & 0.06 & 0.07 & 0.06 & 0.06 \\
\hline & Trial 3 & N/A & 0.04 & 0.04 & 0.06 & 0.06 & 0.05 & 0.06 \\
\hline \multicolumn{2}{|l|}{ Average } & 0.07 & 0.05 & 0.05 & 0.07 & 0.06 & 0.06 & 0.06 \\
\hline \multicolumn{2}{|c|}{ Standard deviation } & 0.01 & 0.02 & 0.02 & 0.01 & 0.01 & 0.01 & 0.01 \\
\hline
\end{tabular}


Table A8.16 - Full Scale Filtrate Data - Suspended Solids Concentration

\begin{tabular}{|c|c|c|c|c|c|c|c|c|}
\hline \multicolumn{2}{|c|}{$\begin{array}{l}\text { Parameter } \\
\text { Polymer }\end{array}$} & \multicolumn{2}{|c|}{$\begin{array}{l}\text { SS (mg/L filtrate) } \\
\text { CB4450 }\end{array}$} & \multirow[b]{2}{*}{3.65} & \multirow[b]{2}{*}{4.55} & \multirow[b]{2}{*}{5.45} & \multirow[b]{2}{*}{6.35} & \multirow[b]{2}{*}{7.25} \\
\hline Dosage & & 1.85 & 2.75 & & & & & \\
\hline \multirow[t]{3}{*}{ Week 1} & Trial 1 & N/A & 2450 & 234 & 168 & 106 & 154 & 102 \\
\hline & Trial 2 & N/A & 3364 & 228 & 264 & 114 & 162 & 84 \\
\hline & Trial 3 & N/A & 3596 & 232 & 216 & 148 & 212 & 96 \\
\hline \multirow[t]{3}{*}{ Week 2} & Trial 1 & N/A & 2628 & 176 & 108 & 158 & 162 & 250 \\
\hline & Trial 2 & N/A & 2688 & 152 & 182 & 156 & 200 & 216 \\
\hline & Trial 3 & N/A & 2572 & 168 & 122 & 166 & 186 & 196 \\
\hline \multicolumn{2}{|l|}{ Average } & & 2883 & 198 & 177 & 141 & 179 & 157 \\
\hline \multicolumn{2}{|c|}{ Standard deviation } & & 475 & 37 & 58 & 25 & 24 & 72 \\
\hline \multicolumn{2}{|c|}{$\begin{array}{l}\text { Parameter } \\
\text { Polymer }\end{array}$} & \multicolumn{2}{|c|}{$\begin{array}{l}\text { SS (mg/L filtrate) } \\
\text { SNF4290 }\end{array}$} & & & & & \\
\hline \multicolumn{2}{|l|}{ Dosage } & 1.85 & 2.75 & 3.65 & 4.55 & 5.45 & 6.35 & 7.25 \\
\hline \multirow[t]{3}{*}{ Week 1} & Trial 1 & 1894 & 152 & 266 & 130 & 156 & 124 & N/A \\
\hline & Trial 2 & 2064 & 164 & 212 & 68 & 92 & 210 & N/A \\
\hline & Trial 3 & 1928 & 160 & 198 & 70 & 138 & 166 & N/A \\
\hline \multirow[t]{3}{*}{ Week 2} & Trial 1 & 2178 & 308 & 232 & 182 & 132 & 198 & N/A \\
\hline & Trial 2 & 2296 & 358 & 196 & 174 & 120 & 164 & N/A \\
\hline & Trial 3 & 2010 & 264 & 206 & 186 & 122 & 162 & N/A \\
\hline \multicolumn{2}{|l|}{ Average } & 2062 & 234 & 218 & 135 & 127 & 171 & \\
\hline \multicolumn{2}{|c|}{ Standard deviation } & 153 & 88 & 27 & 55 & 21 & 30 & \\
\hline \multicolumn{2}{|c|}{$\begin{array}{l}\text { Parameter } \\
\text { Polymer }\end{array}$} & \multicolumn{2}{|c|}{$\begin{array}{l}\text { SS (mg/L filtrate) } \\
\text { EC4925 }\end{array}$} & & & & & \\
\hline \multicolumn{2}{|l|}{ Dosage } & 1.85 & 2.75 & 3.65 & 4.55 & 5.45 & 6.35 & 7.25 \\
\hline \multirow[t]{3}{*}{ Week 1} & Trial 1 & 1252 & 140 & 80 & 98 & 126 & 172 & N/A \\
\hline & Trial 2 & 1274 & 130 & 100 & 112 & 120 & 154 & N/A \\
\hline & Trial 3 & 1276 & 124 & 106 & 96 & 104 & 200 & $\mathrm{~N} / \mathrm{A}$ \\
\hline \multirow[t]{3}{*}{ Week 2} & Trial 1 & N/A & 208 & 94 & 180 & 370 & 336 & 182 \\
\hline & Trial 2 & N/A & 142 & 94 & 156 & 350 & 234 & 138 \\
\hline & Trial 3 & $\mathrm{~N} / \mathrm{A}$ & 202 & 76 & 180 & 350 & 198 & 192 \\
\hline \multicolumn{2}{|c|}{ Average } & 1267 & 158 & 92 & 137 & 237 & 216 & 171 \\
\hline \multicolumn{2}{|c|}{ Standard deviation } & 13 & 37 & 12 & 40 & 132 & 65 & 29 \\
\hline
\end{tabular}


Table A8.17 - Full Scale Filtrate Data - Turbidity

\begin{tabular}{|c|c|c|c|c|c|c|c|c|}
\hline \multirow{2}{*}{\multicolumn{2}{|c|}{$\begin{array}{l}\begin{array}{l}\text { Parameter } \\
\text { Polymer }\end{array} \\
\text { Dosage } \\
\end{array}$}} & \multicolumn{2}{|c|}{$\begin{array}{l}\text { Turbidity (NTU) } \\
\text { CB4450 }\end{array}$} & \multirow[b]{2}{*}{3.65} & \multirow[b]{2}{*}{4.55} & \multirow[b]{2}{*}{5.45} & \multirow[b]{2}{*}{6.35} & \multirow[b]{2}{*}{7.25} \\
\hline & & 1.85 & 2.75 & & & & & \\
\hline \multirow[t]{3}{*}{ Week 1} & Trial 1 & N/A & $\geq 1000$ & 179 & 78 & 40 & 26 & 53 \\
\hline & Trial 2 & N/A & $\geq 1000$ & 154 & 91 & 46 & 40 & 48 \\
\hline & Trial 3 & N/A & $\geq 1000$ & 208 & 90 & 53 & 42 & 53 \\
\hline \multirow[t]{3}{*}{ Week 2} & Trial 1 & N/A & $\geq 1000$ & 98 & 87 & 46 & 44 & 82 \\
\hline & Trial 2 & N/A & $\geq 1000$ & 105 & 83 & 43 & 35 & 88 \\
\hline & Trial 3 & N/A & N/A & N/A & N/A & N/A & N/A & N/A \\
\hline \multicolumn{2}{|l|}{ Average } & & $\geq 1000$ & 149 & 86 & 46 & 38 & 65 \\
\hline \multicolumn{2}{|c|}{ Standard deviation } & & N/A & 47 & 5 & 5 & 7 & 19 \\
\hline \multicolumn{2}{|c|}{$\begin{array}{l}\text { Parameter } \\
\text { Polymer }\end{array}$} & \multicolumn{2}{|c|}{$\begin{array}{l}\text { Turbidity (NTU) } \\
\text { SNF4290 }\end{array}$} & & & & & \\
\hline \multicolumn{2}{|l|}{ Dosage } & 1.85 & 2.75 & 3.65 & 4.55 & 5.45 & 6.35 & 7.25 \\
\hline \multirow[t]{3}{*}{ Week 1} & Trial 1 & $\geq 1000$ & 107 & 81 & 43 & 27 & 15 & N/A \\
\hline & Trial 2 & $\geq 1000$ & 92 & 87 & 47 & 23 & 24 & $\mathrm{~N} / \mathrm{A}$ \\
\hline & Trial 3 & $\geq 1000$ & 104 & 63 & 46 & 17 & 23 & N/A \\
\hline \multirow[t]{3}{*}{ Week 2} & Trial 1 & $\geq 1000$ & 222 & 58 & 38 & 39 & 21 & N/A \\
\hline & Trial 2 & $\geq 1000$ & 175 & 49 & 36 & 42 & 26 & N/A \\
\hline & Trial 3 & N/A & N/A & N/A & N/A & N/A & 26 & $\mathrm{~N} / \mathrm{A}$ \\
\hline \multicolumn{2}{|l|}{ Average } & $\geq 1000$ & 140 & 68 & 42 & 30 & 22 & \\
\hline \multicolumn{2}{|c|}{ Standard deviation } & N/A & 56 & 16 & 5 & 11 & 4 & \\
\hline \multicolumn{4}{|c|}{$\begin{array}{l}\text { Parameter } \\
\text { Polymer }\end{array}$} & & & & & \\
\hline \multicolumn{2}{|l|}{ Dosage } & 1.85 & 2.75 & 3.65 & 4.55 & 5.45 & 6.35 & 7.25 \\
\hline \multirow[t]{3}{*}{ Week 1} & Trial 1 & 236 & 135 & 51 & 33 & 53 & 83 & N/A \\
\hline & Trial 2 & 250 & 162 & 44 & 34 & 51 & 76 & N/A \\
\hline & Trial 3 & 264 & 150 & 44 & 21 & 45 & 66 & N/A \\
\hline \multirow[t]{3}{*}{ Week 2} & Trial 1 & N/A & 108 & 55 & 22 & 42 & 43 & 69 \\
\hline & Trial 2 & N/A & 104 & 41 & 22 & 52 & 66 & 89 \\
\hline & Trial 3 & N/A & 113 & 30 & 22 & 47 & 50 & 45 \\
\hline \multicolumn{2}{|l|}{ Average } & 250 & 129 & 44 & 26 & 48 & 64 & 68 \\
\hline \multicolumn{2}{|c|}{ Standard deviation } & 14 & 24 & 9 & 6 & 4 & 15 & 18 \\
\hline
\end{tabular}


Table A8.18 - Full Scale Filtrate Data - Total Phosphorus

\begin{tabular}{|c|c|c|c|c|c|c|c|c|}
\hline \multirow{2}{*}{\multicolumn{2}{|c|}{$\begin{array}{l}\text { Parameter } \\
\text { Polymer } \\
\text { Dosage } \\
\end{array}$}} & \multicolumn{2}{|c|}{$\begin{array}{l}\text { P (mg/L filtrate) } \\
\text { CB4450 }\end{array}$} & \multirow[b]{2}{*}{3.65} & \multirow[b]{2}{*}{4.55} & \multirow[b]{2}{*}{5.45} & \multirow[b]{2}{*}{6.35} & \multirow[b]{2}{*}{7.25} \\
\hline & & 1.85 & 2.75 & & & & & \\
\hline \multirow[t]{3}{*}{ Week 1} & Trial 1 & N/A & 16.5 & 4.7 & 5 & 4.1 & 4.9 & 6.2 \\
\hline & Trial 2 & N/A & 10.8 & 4.6 & 6.1 & 5 & 7.9 & 4 \\
\hline & Trial 3 & N/A & 9.9 & 4.8 & 5.4 & 5.1 & 3.9 & 4.8 \\
\hline \multirow[t]{3}{*}{ Week 2} & Trial 1 & N/A & 15.7 & 5.4 & 8.2 & 8.3 & 8.6 & 5.5 \\
\hline & Trial 2 & N/A & 15.2 & 7.7 & 6.2 & 8.5 & 3.8 & 7.1 \\
\hline & Trial 3 & N/A & 12.5 & 7.6 & 6.9 & 5.8 & 12 & 8.3 \\
\hline \multicolumn{2}{|l|}{ Average } & & 13.4 & 5.8 & 6.3 & 6.1 & 6.9 & 6.0 \\
\hline \multicolumn{2}{|c|}{ Standard deviation } & & 2.8 & 1.5 & 1.1 & 1.8 & 3.2 & 1.6 \\
\hline \multicolumn{2}{|c|}{$\begin{array}{l}\text { Parameter } \\
\text { Polymer }\end{array}$} & \multicolumn{2}{|c|}{$\begin{array}{l}\text { P (mg/L filtrate) } \\
\text { SNF4290 }\end{array}$} & & & & & \\
\hline \multicolumn{2}{|l|}{ Dosage } & 1.85 & 2.75 & 3.65 & 4.55 & 5.45 & 6.35 & 7.25 \\
\hline \multirow[t]{3}{*}{ Week 1} & Trial 1 & $\geq 30.0$ & 2.7 & 6.4 & 3.3 & 3.2 & 4.6 & N/A \\
\hline & Trial 2 & $\geq 30.0$ & 4.1 & 5.9 & 2.9 & 2.9 & 7.6 & N/A \\
\hline & Trial 3 & $\geq 30.0$ & 4.7 & 4.5 & 3.3 & 3.7 & 4.6 & N/A \\
\hline \multirow[t]{3}{*}{ Week 2} & Trial 1 & $\geq 30.0$ & 10.6 & 6.3 & 5.6 & 5.4 & 4.6 & N/A \\
\hline & Trial 2 & $\geq 30.0$ & 11.2 & 6.1 & 4.8 & 5.6 & 5.4 & N/A \\
\hline & Trial 3 & $\geq 30.0$ & 11.1 & 6.4 & 4.6 & 3.3 & 7.2 & N/A \\
\hline \multicolumn{2}{|l|}{ Average } & $\geq 30.0$ & 7.4 & 5.9 & 4.1 & 4.0 & 5.7 & \\
\hline \multicolumn{2}{|c|}{ Standard deviation } & N/A & 4.0 & 0.7 & 1.1 & 1.2 & 1.4 & \\
\hline \multicolumn{2}{|c|}{$\begin{array}{l}\text { Parameter } \\
\text { Polymer }\end{array}$} & \multicolumn{2}{|c|}{$\begin{array}{l}\text { P (mg/L filtrate) } \\
\text { EC4925 }\end{array}$} & & & & & \\
\hline \multicolumn{2}{|l|}{ Dosage } & 1.85 & 2.75 & 3.65 & 4.55 & 5.45 & 6.35 & 7.25 \\
\hline \multirow[t]{3}{*}{ Week 1} & Trial 1 & 7.8 & 3.8 & 3.8 & 6.1 & 3 & 4.1 & N/A \\
\hline & Trial 2 & 8.9 & 4.3 & 3.5 & 2.7 & 4.5 & 4.2 & N/A \\
\hline & Trial 3 & 9.4 & 4.8 & 3.7 & 2.6 & 6.1 & 4.5 & N/A \\
\hline \multirow[t]{3}{*}{ Week 2} & Trial 1 & N/A & 4.1 & 3.7 & 2.9 & 4 & 3.4 & 3.6 \\
\hline & Trial 2 & N/A & 4.5 & 3.1 & 2.9 & 4.2 & 4.3 & 3.8 \\
\hline & Trial 3 & N/A & 4.9 & 3.5 & 3.3 & 3.7 & 2.9 & 4.9 \\
\hline \multicolumn{2}{|l|}{ Average } & 8.7 & 4.4 & 3.6 & 3.4 & 4.3 & 3.9 & 4.1 \\
\hline \multicolumn{2}{|c|}{ Standard deviation } & 0.8 & 0.4 & 0.3 & 1.3 & 1.0 & 0.6 & 0.7 \\
\hline
\end{tabular}


Table A8.19 - Full Scale Filtrate Data - Ammonia

\begin{tabular}{|c|c|c|c|c|c|c|c|c|}
\hline \multirow{2}{*}{\multicolumn{2}{|c|}{$\begin{array}{l}\begin{array}{l}\text { Parameter } \\
\text { Polymer }\end{array} \\
\text { Dosage } \\
\end{array}$}} & \multicolumn{2}{|c|}{$\begin{array}{l}\mathrm{NH}_{3} \text { (mg/L filtrate) } \\
\text { CB4450 }\end{array}$} & \multirow[b]{2}{*}{3.65} & \multirow[b]{2}{*}{4.55} & \multirow[b]{2}{*}{5.45} & \multirow[b]{2}{*}{6.35} & \multirow[b]{2}{*}{7.25} \\
\hline & & 1.85 & 2.75 & & & & & \\
\hline \multirow[t]{3}{*}{ Week 1} & Trial 1 & N/A & $\geq 3.00$ & 1.78 & 1.67 & 1.31 & 0.55 & 0.54 \\
\hline & Trial 2 & N/A & $\geq 3.00$ & 1.59 & 1.82 & 1.46 & 0.43 & 0.68 \\
\hline & Trial 3 & N/A & $\geq 3.00$ & 1.67 & 1.92 & 1.57 & 0.39 & 0.61 \\
\hline \multirow[t]{3}{*}{ Week 2} & Trial 1 & N/A & 1.62 & 0.60 & 0.28 & 0.36 & 0.51 & 0.65 \\
\hline & Trial 2 & N/A & 1.81 & 0.50 & 0.70 & 0.41 & 0.43 & 0.5 \\
\hline & Trial 3 & N/A & 1.29 & 0.34 & 0.80 & 0.44 & 0.41 & 0.49 \\
\hline \multicolumn{2}{|l|}{ Average } & & $\mathrm{N} / \mathrm{A}$ & 1.08 & 1.20 & 0.93 & 0.45 & 0.58 \\
\hline \multicolumn{2}{|c|}{ Standard deviation } & & N/A & 0.67 & 0.69 & 0.58 & 0.06 & 0.08 \\
\hline \multicolumn{2}{|c|}{$\begin{array}{l}\text { Parameter } \\
\text { Polymer }\end{array}$} & \multicolumn{2}{|c|}{$\begin{array}{l}\mathrm{NH}_{3} \text { (mg/L filtrate) } \\
\text { SNF4290 }\end{array}$} & & & & & \\
\hline \multicolumn{2}{|l|}{ Dosage } & 1.85 & 2.75 & 3.65 & 4.55 & 5.45 & 6.35 & 7.25 \\
\hline \multirow[t]{3}{*}{ Week 1} & Trial 1 & $\geq 3.00$ & 0.40 & 0.67 & 0.35 & 0.36 & 0.46 & N/A \\
\hline & Trial 2 & $\geq 3.00$ & 0.53 & 0.55 & 0.27 & 0.29 & 0.34 & N/A \\
\hline & Trial 3 & $\geq 3.00$ & 0.50 & 0.52 & 0.36 & 0.31 & 0.45 & N/A \\
\hline \multirow[t]{3}{*}{ Week 2} & Trial 1 & $\geq 3.00$ & 0.94 & 0.57 & 0.34 & 0.43 & 0.47 & N/A \\
\hline & Trial 2 & $\geq 3.00$ & 0.95 & 0.57 & 0.41 & 0.31 & 0.45 & N/A \\
\hline & Trial 3 & $\geq 3.00$ & 0.70 & 0.63 & 0.29 & 0.36 & 0.48 & N/A \\
\hline \multicolumn{2}{|l|}{ Average } & $\geq 3.00$ & 0.67 & 0.59 & 0.34 & 0.34 & 0.44 & \\
\hline \multicolumn{2}{|c|}{ Standard deviation } & N/A & 0.23 & 0.06 & 0.05 & 0.05 & 0.05 & \\
\hline \multicolumn{2}{|c|}{$\begin{array}{l}\text { Parameter } \\
\text { Polymer }\end{array}$} & \multicolumn{2}{|c|}{$\begin{array}{l}\mathrm{NH}_{3}(\mathrm{mg} / \mathrm{L} \text { filtrate) } \\
\text { EC4925 }\end{array}$} & & & & & \\
\hline \multicolumn{2}{|l|}{ Dosage } & 1.85 & 2.75 & 3.65 & 4.55 & 5.45 & 6.35 & 7.25 \\
\hline \multirow[t]{3}{*}{ Week 1} & Trial 1 & 0.89 & 0.25 & 0.35 & 0.37 & 0.43 & 0.46 & N/A \\
\hline & Trial 2 & 1.28 & 0.21 & 0.35 & 0.36 & 0.41 & 0.47 & N/A \\
\hline & Trial 3 & 0.80 & 0.29 & 0.39 & 0.35 & 0.46 & 0.51 & N/A \\
\hline \multirow[t]{3}{*}{ Week 2} & Trial 1 & N/A & 0.50 & 0.36 & 0.41 & 0.45 & 0.49 & 0.61 \\
\hline & Trial 2 & N/A & 0.64 & 0.39 & 0.40 & 0.42 & 0.50 & 0.61 \\
\hline & Trial 3 & N/A & 0.46 & 0.35 & 0.43 & 0.45 & 0.54 & 0.59 \\
\hline \multicolumn{2}{|l|}{ Average } & 0.99 & 0.39 & 0.37 & 0.39 & 0.44 & 0.50 & 0.60 \\
\hline \multicolumn{2}{|c|}{ Standard deviation } & 0.26 & 0.17 & 0.02 & 0.03 & 0.02 & 0.03 & 0.01 \\
\hline
\end{tabular}




\section{A8.3 E. coli Enumeration Data}

Table A8.20 - E. coli Concentration Measured at Crystal Beach WWTP

\begin{tabular}{|l|c|c|c|}
\hline \multirow{2}{*}{ Parameter } & \multicolumn{1}{|c}{} \\
(cfu/100 mL) & \multicolumn{2}{|c}{} \\
\hline Sample Location & Aeration Foam & Clarifier Foam & Clarifier Effluent \\
\hline Trial 1 & 15531000 & 7270000 & 130000 \\
Trial 2 & 24200000 & 14136000 & 155300 \\
Trial 3 & 29875000 & 8400000 & 147000 \\
\hline Average & 23202000 & 9935333 & 144100 \\
\hline Std. deviation & 7223890 & 3681498 & 12897 \\
\hline
\end{tabular}

\section{A7.4 Process Data from Crystal Beach WWTP}

Table A8.21 - Solid Retention Time Observed at Crystal Beach WWTP 2006

\begin{tabular}{|c|c|c|c|c|c|c|c|c|c|c|c|}
\hline Date & SRT & F/M & Date & SRT & F/M & Date & SRT & F/M & Date & SRT & F/M \\
\hline 1-Jan & 6.31 & & 31-Mar & 4.47 & & 29-Jun & 2.43 & & 27-Sep & 3.99 & \\
\hline 2-Jan & 12.65 & & 1-Apr & 5.33 & & 30-Jun & 4.71 & & 28-Sep & 1.24 & \\
\hline 3-Jan & 13.48 & 0.13 & 2-Apr & 4.67 & 0.80 & 1-Jul & 3.59 & & 29-Sep & 2.28 & \\
\hline 4-Jan & 10.21 & & 3-Apr & 5.76 & & 2-Jul & 1.26 & & 30-Sep & 2.35 & \\
\hline 5-Jan & 15.78 & & 4-Apr & 5.64 & & 3-Jul & 3.00 & 0.39 & 1-Oct & 3.34 & 0.24 \\
\hline 6-Jan & 5.94 & & 5-Apr & 9.95 & & 4-Jul & 3.39 & & 2-Oct & 6.88 & \\
\hline 7-Jan & 6.32 & & 6-Apr & 8.92 & & 5-Jul & 2.36 & & 3-Oct & 3.10 & \\
\hline 8-Jan & 8.11 & & 7-Apr & 5.49 & & 6-Jul & 4.81 & & 4-Oct & 6.06 & \\
\hline 9-Jan & 3.29 & 0.46 & 8-Apr & 4.77 & & 7-Jul & 4.66 & & 5-Oct & 3.44 & \\
\hline 10-Jan & 9.30 & & 9-Apr & 4.51 & & 8-Jul & 4.31 & & 6-Oct & 2.11 & \\
\hline 11-Jan & 21.01 & & 10-Apr & 7.35 & 0.31 & 9-Jul & 3.34 & 0.31 & 7-Oct & 3.65 & \\
\hline 12-Jan & 7.82 & & 11-Apr & 10.45 & & 10-Jul & 3.51 & & 8-Oct & 2.53 & \\
\hline 13-Jan & 4.79 & & 12-Apr & 4.54 & & 11-Jul & 3.66 & & 9-Oct & 55.45 & \\
\hline 14-Jan & 4.38 & & 13-Apr & 6.82 & & 12-Jul & 2.10 & & 10-Oct & 4.96 & \\
\hline 15-Jan & 11.72 & & 14-Apr & 2.91 & & 13-Jul & 2.88 & & 11-Oct & 1.30 & \\
\hline 16-Jan & 9.19 & & 15-Apr & 3.69 & & 14-Jul & 3.37 & & 12-Oct & 0.83 & 0.18 \\
\hline 17-Jan & 5.61 & 0.64 & 16-Apr & 3.49 & & 15-Jul & 3.43 & & 13-Oct & 1.15 & \\
\hline 18-Jan & 8.08 & & 17-Apr & 6.62 & & 16-Jul & 15.82 & & 14-Oct & 1.11 & \\
\hline 19-Jan & 5.04 & & 18-Apr & 3.69 & & 17-Jul & 3.94 & 0.23 & 15-Oct & 1.12 & \\
\hline 20-Jan & 11.05 & & 19-Apr & 3.16 & & 18-Jul & 4.43 & & 16-Oct & 1.58 & \\
\hline 21-Jan & 10.31 & & 20-Apr & 8.24 & & 19-Jul & 3.79 & & 17-Oct & 1.52 & 0.80 \\
\hline 22-Jan & 6.22 & & 21-Apr & 7.35 & & 20-Jul & 2.88 & & 18-Oct & 1.17 & \\
\hline 23-Jan & 10.87 & 0.11 & 22-Apr & 3.76 & & 21-Jul & 1.25 & & 19-Oct & 5.51 & \\
\hline 24-Jan & 17.08 & & 23-Apr & 2.61 & & 22-Jul & 2.40 & & 20-Oct & 2.89 & \\
\hline 25-Jan & 3.89 & & 24-Apr & 6.90 & 0.58 & 23-Jul & 5.02 & 0.35 & 21-Oct & 5.88 & \\
\hline 26-Jan & 11.89 & & 25-Apr & 6.18 & & 24-Jul & 4.01 & & 22-Oct & 1.88 & \\
\hline 27-Jan & 16.89 & & 26-Apr & 6.25 & & 25-JuI & 8.30 & & 23-Oct & 0.97 & \\
\hline
\end{tabular}




\begin{tabular}{|c|c|c|c|c|c|c|c|c|c|c|c|}
\hline 28-Jan & 12.37 & & 27-Apr & 4.29 & & 26-Jul & 6.54 & & 24-Oct & 4.42 & \\
\hline 29-Jan & 11.60 & & 28-Apr & 4.53 & & 27-Jul & 5.92 & & 25-Oct & 3.71 & 0.62 \\
\hline 30-Jan & 2.82 & & 29-Apr & 6.31 & & 28-Jul & 2.42 & & 26-Oct & 4.34 & \\
\hline 31-Jan & \begin{tabular}{l|}
4.55 \\
\end{tabular} & 0.52 & 30-Apr & \begin{tabular}{l|l}
6.31 \\
\end{tabular} & 0.15 & 29-Jul & 2.64 & & 27-Oct & 2.83 & \\
\hline 1-Feb & 8.25 & & 1-May & 5.22 & & 30-Jul & 3.03 & & 28-Oct & 1.24 & \\
\hline 2-Feb & 47.37 & & 2-May & 4.31 & & 31-Jul & 3.32 & 0.56 & 29-Oct & 1.42 & \\
\hline 3-Feb & 11.18 & & 3-May & 5.01 & & 1-Aug & 3.17 & & 30-Oct & 2.36 & 0.27 \\
\hline 4-Feb & 9.81 & & 4-May & 4.11 & & 2-Aug & 3.37 & & 31-0ct & 3.25 & \\
\hline 5-Feb & 4.83 & & 5-May & 5.14 & & 3-Aug & 3.05 & & 1-Nov & 2.31 & \\
\hline 6-Feb & 8.11 & 0.49 & 6-May & \begin{tabular}{l|}
4.63 \\
\end{tabular} & & 4-Aug & 2.36 & & 2-Nov & 3.08 & \\
\hline 7-Feb & 5.47 & & 7-May & 3.19 & & 5-Aug & 3.57 & & 3-Nov & 5.58 & \\
\hline 8-Feb & 4.83 & & 8-May & 3.47 & 0.14 & 6-Aug & 3.83 & & 4-Nov & 3.90 & \\
\hline 9-Feb & 3.63 & & 9-May & 5.95 & & 7-Aug & 4.59 & 0.33 & 5-Nov & 2.17 & \\
\hline 10-Feb & 4.37 & & 10-May & 4.17 & & 8-Aug & 5.08 & & 6-Nov & 3.92 & \\
\hline 11-Feb & 9.04 & & 11-May & 2.93 & & 9-Aug & 3.53 & & 7-Nov & 5.44 & 0.27 \\
\hline 12-Feb & 3.75 & & 12-May & 2.05 & & 10-Aug & 2.94 & & 8-Nov & 5.03 & \\
\hline 13-Feb & 5.19 & & 13-May & 2.82 & & 11-Aug & 4.41 & & 9-Nov & \begin{tabular}{l|l}
0.99 \\
\end{tabular} & \\
\hline 14-Feb & 9.42 & 0.21 & 14-May & 15.53 & 0.19 & 12-Aug & 4.50 & & 10-Nov & 2.06 & \\
\hline 15-Feb & 6.20 & & 15-May & 10.11 & & 13-Aug & 3.18 & & 11-Nov & 4.24 & \\
\hline 16-Feb & 8.24 & & 16-May & 4.43 & & 14-Aug & 4.21 & 0.35 & 12-Nov & 2.47 & \\
\hline 17-Feb & 6.94 & & 17-May & 1.52 & & 15-Aug & 5.65 & & 13-Nov & 1.57 & 0.39 \\
\hline 18-Feb & 9.53 & & 18-May & 5.58 & & 16-Aug & 5.05 & & 14-Nov & 3.00 & \\
\hline 19-Feb & 14.08 & & 19-May & 6.39 & & 17-Aug & 3.14 & & 15-Nov & 2.47 & \\
\hline 20-Feb & 8.96 & & 20-May & 3.82 & & 18-Aug & 3.27 & & 16-Nov & 1.22 & \\
\hline 21-Feb & 12.41 & & 21-May & 3.82 & & 19-Aug & 2.82 & & 17-Nov & 0.84 & \\
\hline 22-Feb & 5.41 & & 22-May & 4.19 & 0.28 & 20-Aug & 2.91 & 0.38 & 18-Nov & 2.31 & \\
\hline 23-Feb & 7.12 & 0.44 & 23-May & 8.11 & & 21-Aug & 2.28 & & 19-Nov & 6.05 & \\
\hline 24-Feb & 8.09 & & 24-May & 5.17 & & 22-Aug & 2.69 & & 20-Nov & 3.08 & \\
\hline 25-Feb & 10.02 & & 25-May & 5.51 & & 23-Aug & 3.34 & & 21-Nov & 3.24 & 0.38 \\
\hline 26-Feb & 4.76 & & 26-May & 5.71 & & 24-Aug & 5.26 & & 22-Nov & 2.86 & \\
\hline 27-Feb & 6.12 & & 27-May & 3.44 & & 25-Aug & 3.71 & & 23-Nov & 5.20 & \\
\hline 28-Feb & 11.28 & 0.39 & 28-May & 3.57 & 0.26 & 26-Aug & 3.47 & & 24-Nov & 4.18 & \\
\hline 29-Feb & 7.43 & & 29-May & 3.84 & & 27-Aug & 2.50 & & 25-Nov & 8.74 & \\
\hline 1-Mar & 6.92 & & 30-May & 7.58 & & 28-Aug & 2.21 & 0.44 & 26-Nov & 6.09 & \\
\hline 2-Mar & 11.27 & & 31-May & 3.44 & & 29-Aug & 2.79 & & 27-Nov & 2.27 & 0.11 \\
\hline 3-Mar & 7.62 & & 1-Jun & 2.79 & & 30-Aug & 2.03 & & 28-Nov & 2.26 & \\
\hline 4-Mar & 14.93 & & 2-Jun & 5.53 & & 31-Aug & 2.35 & & 29-Nov & 3.20 & \\
\hline 5-Mar & 4.48 & 0.85 & 3-Jun & 19.23 & & 1-Sep & 3.04 & & 30-Nov & 6.42 & \\
\hline 6-Mar & 6.45 & & 4-Jun & 5.03 & & 2-Sep & 4.38 & & 1-Dec & 1.91 & \\
\hline 7-Mar & 3.36 & & 5-Jun & 2.82 & 0.18 & 3-Sep & 1.59 & & 2-Dec & 0.31 & \\
\hline 8-Mar & 2.31 & & 6-Jun & 4.84 & & 4-Sep & 0.48 & \begin{tabular}{|l|}
0.35 \\
\end{tabular} & 3-Dec & 3.68 & \\
\hline 9-Mar & 2.07 & & 7-Jun & 4.91 & & 5-Sep & 2.63 & & 4-Dec & 9.42 & \\
\hline 10-Mar & 5.27 & & 8-Jun & 1.67 & & 6-Sep & 2.32 & 0.46 & 5-Dec & 10.93 & 0.17 \\
\hline 11-Mar & 8.82 & & 9-Jun & 3.21 & & 7-Sep & 2.87 & & 6-Dec & 10.62 & \\
\hline 12-Mar & 3.87 & & 10-Jun & 3.69 & & 8-Sep & 3.87 & & 7-Dec & 7.13 & \\
\hline 13-Mar & 4.57 & 1.25 & 11-Jun & 2.90 & 0.21 & 9-Sep & 3.44 & & 8-Dec & 3.56 & \\
\hline 14-Mar & 2.74 & & 12-Jun & 4.74 & & 10-Sep & 3.70 & & 9.Dec & 20.85 & \\
\hline 15-Mar & 6.30 & & 13-Jun & 2.61 & & 11-Sep & 2.81 & & 10-Dec & 2.90 & \\
\hline
\end{tabular}




\begin{tabular}{||l|r|l||l|l|l||l|l|l||l|r|l||}
\hline 16-Mar & 5.35 & & 14-Jun & 3.90 & 0.21 & 12-Sep & 2.85 & & 11-Dec & 13.48 & \\
\hline 17-Mar & 4.83 & & 15-Jun & 2.23 & & 13-Sep & 1.67 & & 12-Dec & 14.43 & 0.19 \\
\hline 18-Mar & 6.33 & & 16-Jun & 3.63 & & 14-Sep & 2.59 & & 13-Dec & 6.13 & \\
\hline 19-Mar & 8.97 & 0.66 & 17-Jun & 4.13 & & 15-Sep & 3.24 & & 14-Dec & 3.69 & \\
\hline 20-Mar & 7.92 & & 18-Jun & 0.34 & & 16-Sep & 3.21 & & 15-Dec & 3.61 & \\
\hline 21-Mar & 2.91 & & 19-Jun & 3.72 & 0.30 & 17-Sep & 2.71 & & 16-Dec & 2.77 & \\
\hline 22-Mar & 2.51 & & 20-Jun & 3.63 & & 18-Sep & 1.02 & 0.69 & 17-Dec & 5.16 & \\
\hline 23-Mar & 4.81 & & 21-Jun & 5.30 & & 19-Sep & 1.60 & & 18-Dec & 5.54 & \\
\hline 24-Mar & 7.79 & & 22-Jun & 5.53 & & 20-Sep & 2.00 & & 19-Dec & 7.10 & \\
\hline 25-Mar & 6.72 & & 23-Jun & 7.09 & & 21-Sep & 7.12 & & 20-Dec & 4.23 & 0.37 \\
\hline 26-Mar & 2.73 & & 24-Jun & 8.70 & & 22-Sep & 4.96 & & 21-Dec & 3.67 & \\
\hline 27-Mar & 7.11 & 0.76 & 25-Jun & 7.92 & 0.30 & 23-Sep & 2.19 & & 22-Dec & 5.34 & \\
\hline 28-Mar & 3.29 & & 26-Jun & 3.32 & & 24-Sep & 0.80 & 0.23 & 23-Dec & 3.41 & \\
\hline 29-Mar & 5.37 & & 27-Jun & 3.90 & & 25-Sep & 4.89 & & 24-Dec & 3.89 & \\
\hline 30-Mar & 12.37 & & 28-Jun & 6.61 & & 26-Sep & 3.33 & & & & \\
\hline
\end{tabular}

Table A7.22 - Dissolved Oxygen Concentration Observed at Crystal Beach WWTP December 2006

\begin{tabular}{|c|c|}
\hline Date & DO Concentration \\
\hline 11-Dec & 7.0 \\
\hline 12-Dec & 6.5 \\
\hline 13-Dec & 6.7 \\
\hline 14-Dec & 6.5 \\
\hline 15-Dec & 7.0 \\
\hline 16-Dec & 6.7 \\
\hline 17-Dec & 5.9 \\
\hline 18-Dec & 6.6 \\
\hline 19-Dec & 6.4 \\
\hline 20-Dec & 6.4 \\
\hline 21-Dec & 7.6 \\
\hline 22-Dec & 7.6 \\
\hline 23-Dec & 7.1 \\
\hline 24-Dec & 6.8 \\
\hline 25-Dec & 8.0 \\
\hline 26-Dec & 7.8 \\
\hline 27-Dec & 7.8 \\
\hline 28-Dec & 7.4 \\
\hline 29-Dec & 6.6 \\
\hline 30-Dec & 8.0 \\
\hline 31-Dec & 7.8 \\
\hline Average & 7.1 \\
\hline Maximum & 8.0 \\
\hline Minimum & 5.9 \\
\hline
\end{tabular}

